\title{
WestVirginiaUniversity
}

THE RESEARCH REPOSITORY @ WVU

Graduate Theses, Dissertations, and Problem Reports

2010

\section{Four Trinity Sunday Cantatas by J. S. Bach: An Examination and Comparison}

Jeffry Blake Johnson

West Virginia University

Follow this and additional works at: https://researchrepository.wvu.edu/etd

\section{Recommended Citation}

Johnson, Jeffry Blake, "Four Trinity Sunday Cantatas by J. S. Bach: An Examination and Comparison" (2010). Graduate Theses, Dissertations, and Problem Reports. 3534.

https://researchrepository.wvu.edu/etd/3534

This Dissertation is protected by copyright and/or related rights. It has been brought to you by the The Research Repository @ WVU with permission from the rights-holder(s). You are free to use this Dissertation in any way that is permitted by the copyright and related rights legislation that applies to your use. For other uses you must obtain permission from the rights-holder(s) directly, unless additional rights are indicated by a Creative Commons license in the record and/ or on the work itself. This Dissertation has been accepted for inclusion in WVU Graduate Theses, Dissertations, and Problem Reports collection by an authorized administrator of The Research Repository @ WVU.

For more information, please contact researchrepository@mail.wvu.edu. 
Four Trinity Sunday Cantatas by J. S. Bach:

An Examination and Comparison

Jeffry Blake Johnson

Research Project submitted to the

College of Creative Arts

at West Virginia University

in partial fulfillment of the requirements

for the degree of

Doctor of Musical Arts

in

Performance: Conducting

Kathleen Shannon, DMA, Chair and Research Advisor

Mary Ferer, PhD, Research Advisor

Cynthia Anderson, MM

John Hendricks III, MM

Lawrence T. Nichols, PhD

Division of Music

Morgantown, West Virginia

2010

Keywords: Johann Sebastian Bach, Bach cantatas, Leipzig cantatas,

Trinity Sunday music, Philosophical/Theological ideas of Bach

Copyright 2010 Jeffry Blake Johnson 


\section{ABSTRACT \\ Four Trinity Sunday Cantatas by J. S. Bach: An Examination and Comparison}

\section{Jeffry Blake Johnson}

While the four cantatas presented on Trinity Sunday during Bach’s Leipzig years - BWV 194, 176, 165, and 129 - were all intended for the same liturgical day, a significant diversity exists among the four compositions. This diversity results from the variety of source material on which the cantatas were based, including material composed during the Leipzig years as well as material re-worked from previous Bach cantatas. The diversity also results from the different librettos and librettists that were utilized for the cantatas. Other factors include the variety of the cantatas' movement structures, performing forces, and the theological/philosophical themes that are central to each composition. This document is a study of the four cantatas, first examining the compositions in detail, then examining the compositions by their commonalities and their dissimilarities, with specific attention to the methods by which Bach presented the theological/philosophical messages in each cantata. An appendix of translations and scriptural allusions for each cantata movement is also included at the close of the document. The variety of perspectives employed in this document forms a unique examination of the four Trinity Sunday cantatas that has not previously been seen in Bach scholarship. 


\section{Table of Contents}

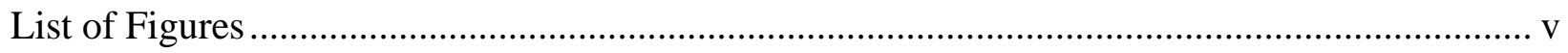

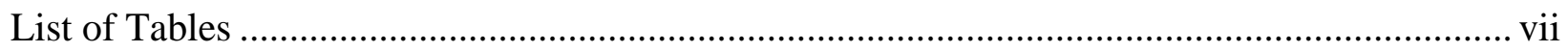

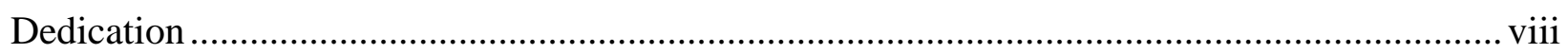

Chapter 1: Introduction and Selected Historical Background ............................................... 1

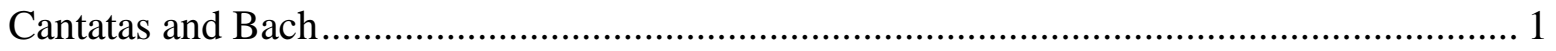

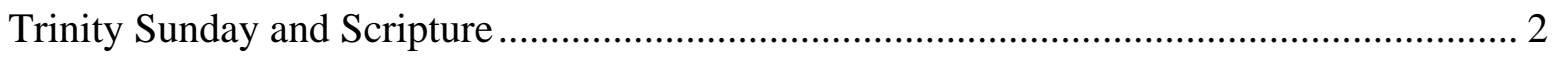

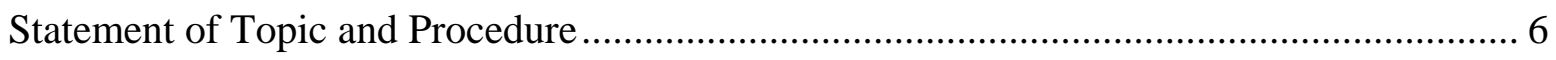

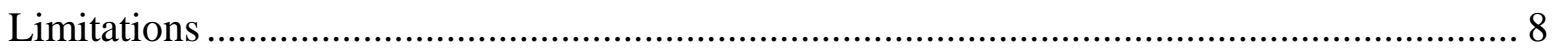

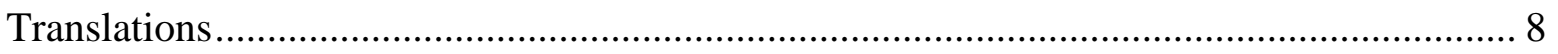

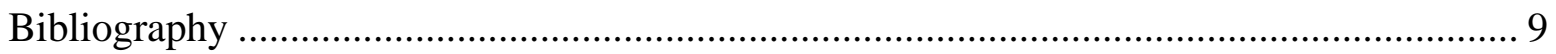

Chapter 2: Höchsterwünschtes Freudenfest, BWV 194 .................................................... 10

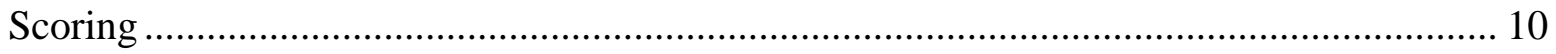

Performance/Compositional History ...................................................................... 11

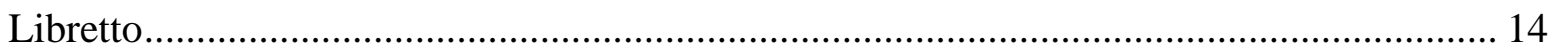

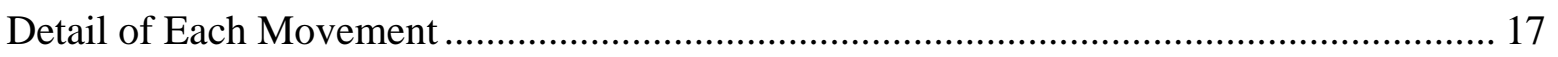

Chapter 3: O heilges Geist- und Wasserbad, BWV 165......................................................... 43

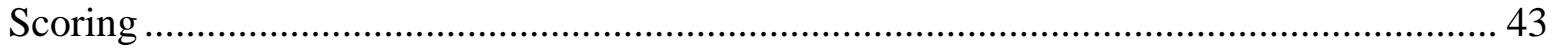

Performance/Compositional History .................................................................... 44

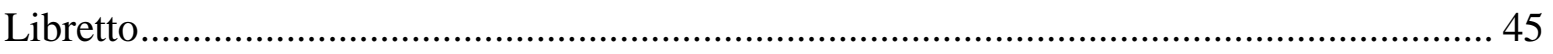

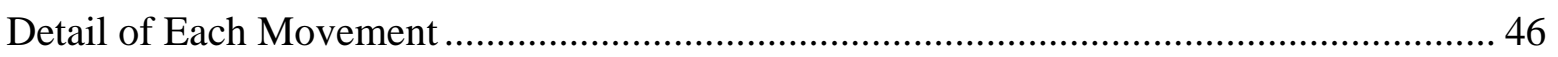

Chapter 4: Es ist ein trotzig un verzagt Ding, BWV 176....................................................... 58

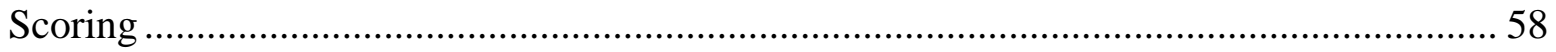

Performance/Compositional History ...................................................................... 59

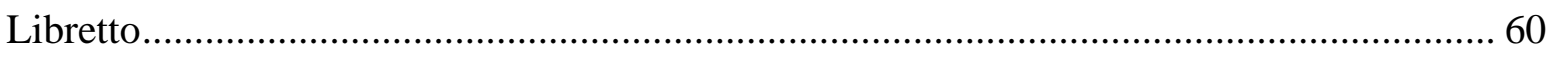

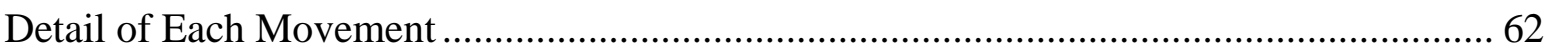

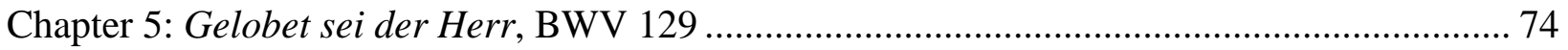

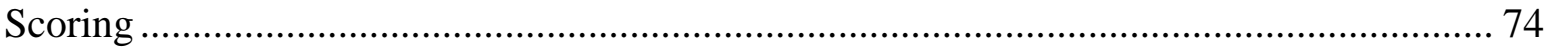

Performance/Compositional History …................................................................... 75

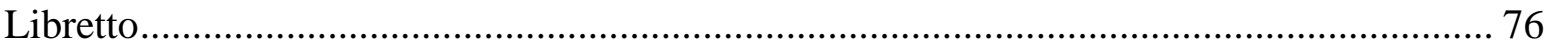

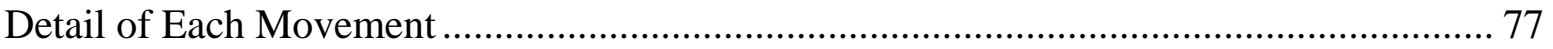

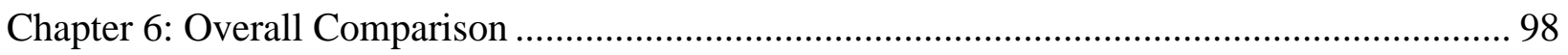

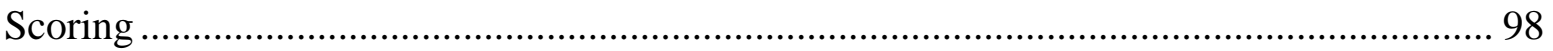


Performance/Compositional History .............................................................................. 101

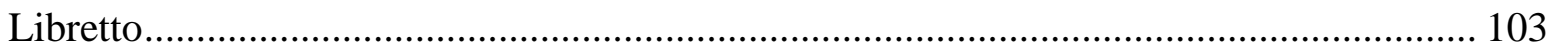

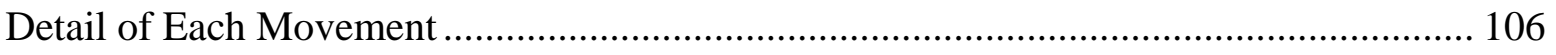

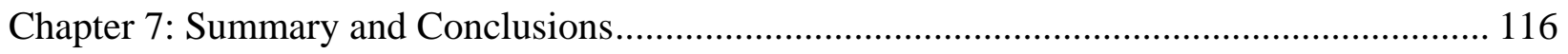

Question 1: From what musical and textual material did Bach compose his Trinity Sunday cantatas?............................................................................................................... 116

Question 2: How do the components and messages of the Trinity Sunday cantatas compare with one another?

Question 3: How did Bach use the musical and textual components of the cantatas to communicate his intended theological/philosophical messages? ................................... 118

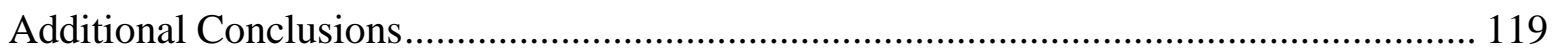

Bach created only four Trinity Sunday cantatas for practical, creative, and theologically/spiritually expressive reasons.

Bach made choices about instrumentation based on availability of musicians and his intention of musical/theological expression. Instruments of the oboe family were the most prominently featured wind instruments of Bach's cantatas due to the excellent skills of Bach’s Leipzig oboists.................................................................................................. 121

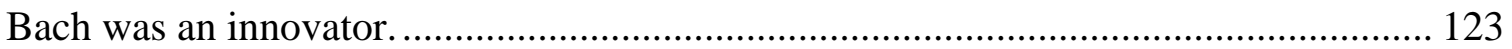

The Trinity Sunday cantatas reflect some of the most important features of the Jahrgänge during which they were first heard in Leipzig................................................................ 124

The text and message were of prime importance in Bach's cantatas. ............................ 125

Appendix: Text translations and Scriptural Allusions .............................................................. 127

Höchsterwünschtes Freudenfest, BWV 194 ……………….......................................... 127

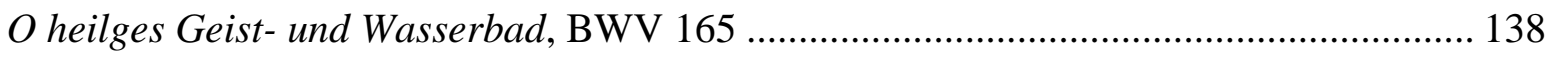

Es ist ein trotzig un verzagt Ding, BWV 176 .................................................................. 144

Gelobet sei der Herr, BWV 129 ................................................................................ 148

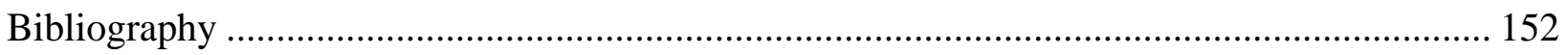




\section{List of Figures}

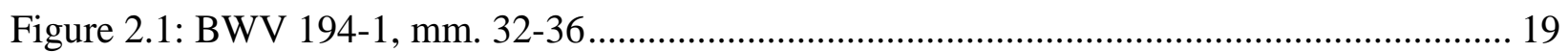

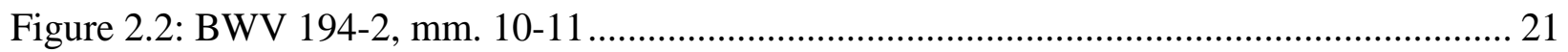

Figure 2.3: BWV 194-2, mm. 14-16 .......................................................................... 21

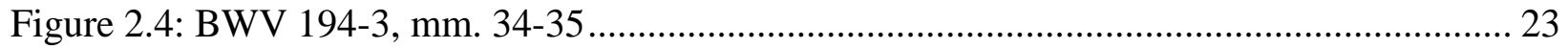

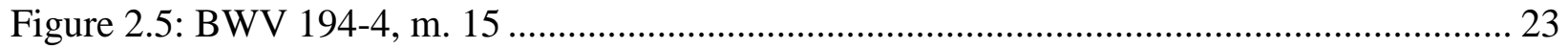

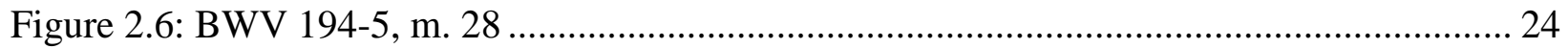

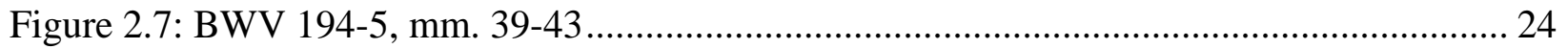

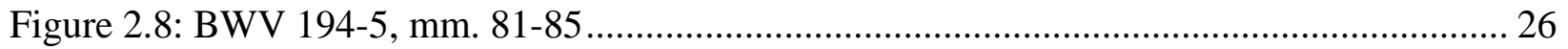

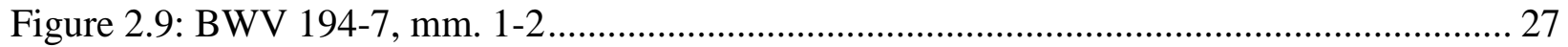

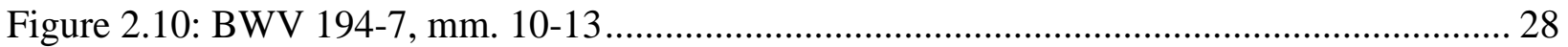

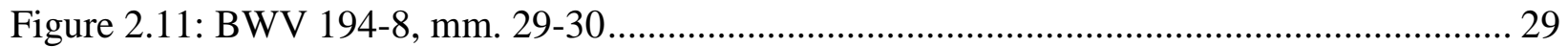

Figure 2.12: BWV 194-8, mm. 21-23............................................................................. 30

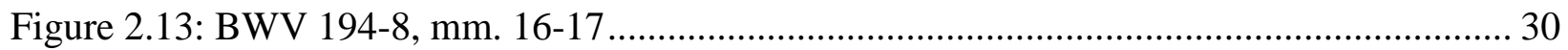

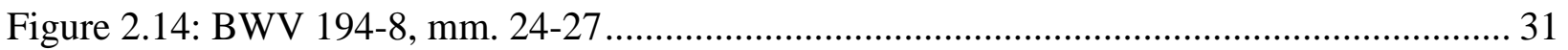

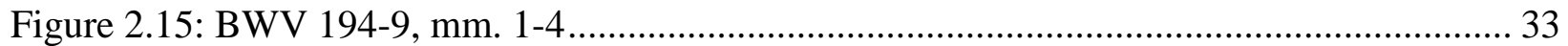

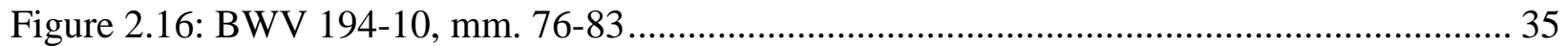

Figure 2.17: BWV 194-10, mm. 31-34 and mm. 145-148 ………………………….............. 36

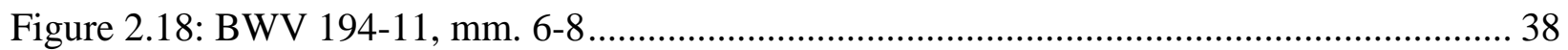

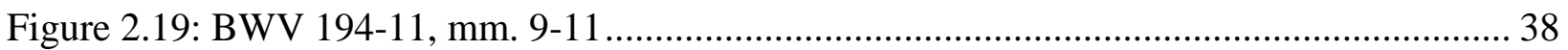

Figure 2.20: BWV 194-12, mm. 12-16 ............................................................................ 41

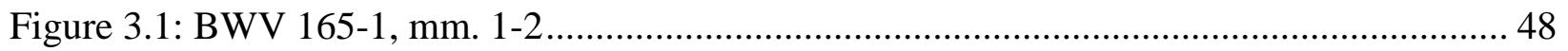

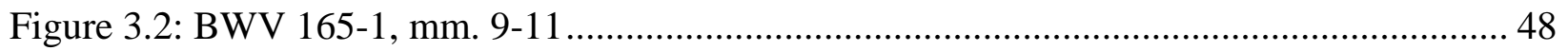

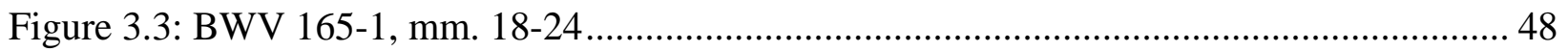

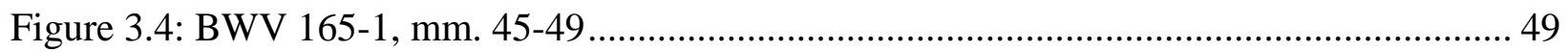

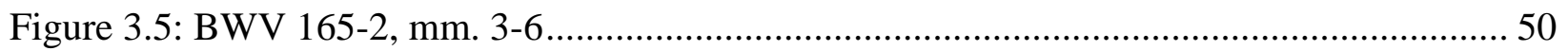

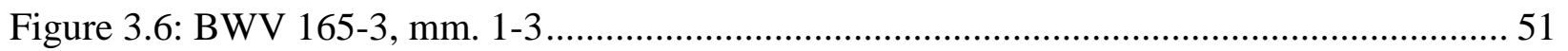

Figure 3.7: BWV 165-3, mm. 17-20 ………………............................................... 51

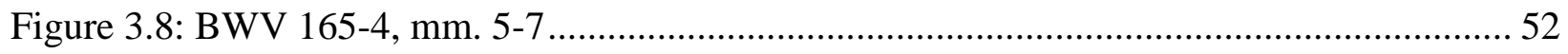

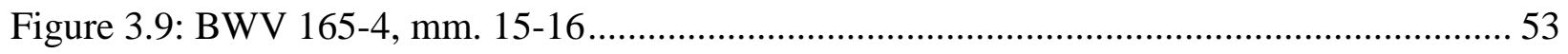

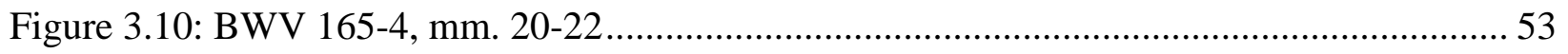

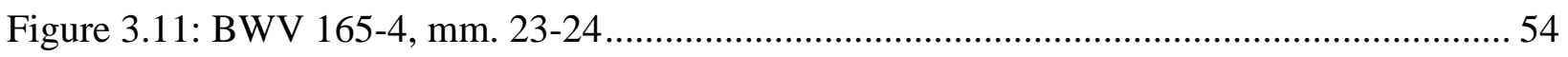

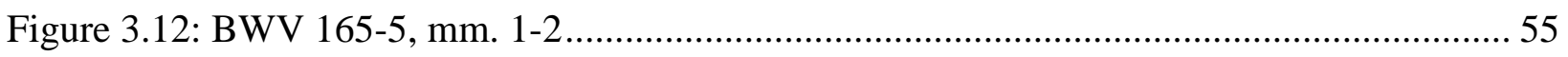




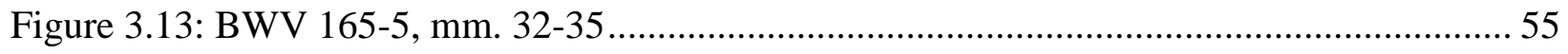

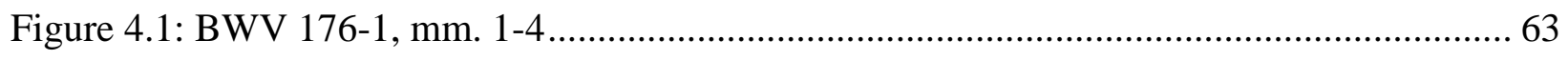

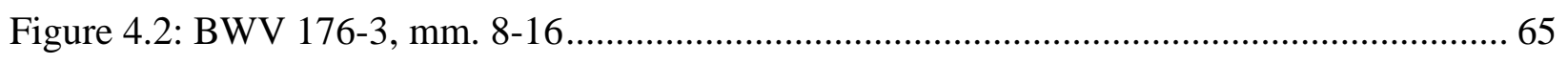

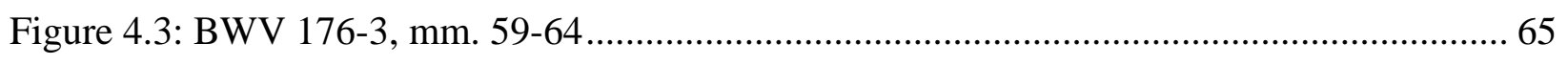

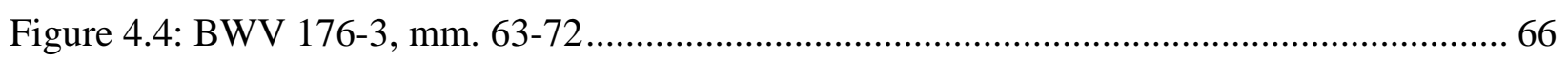

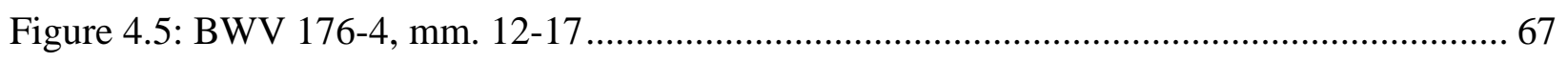

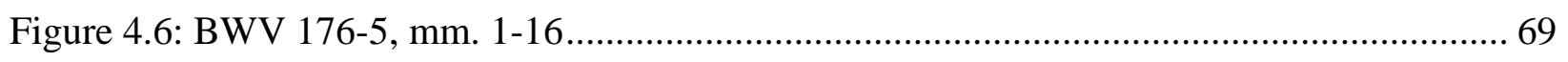

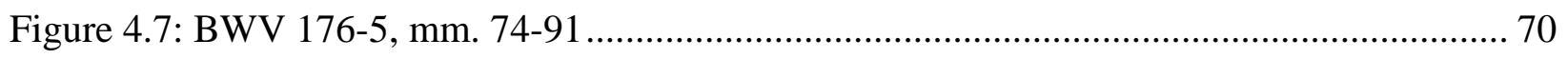

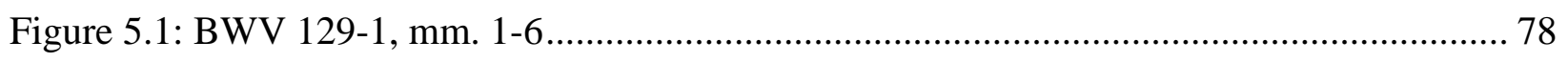

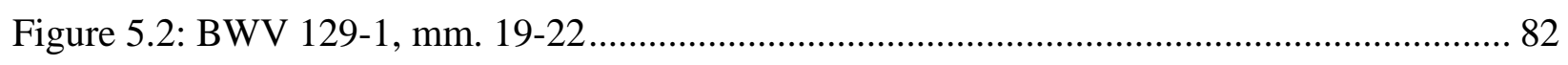

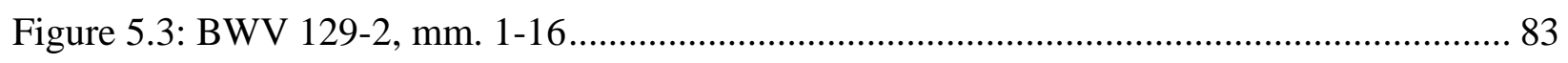

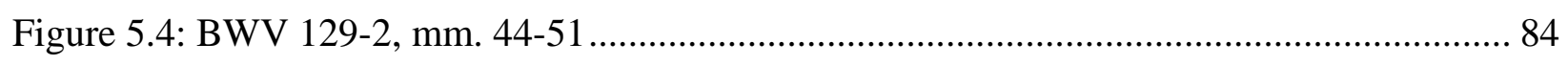

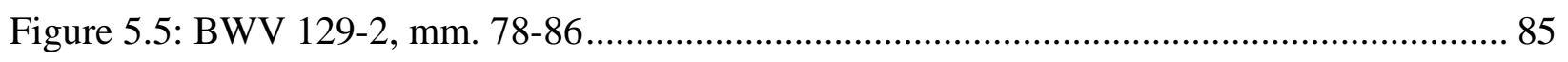

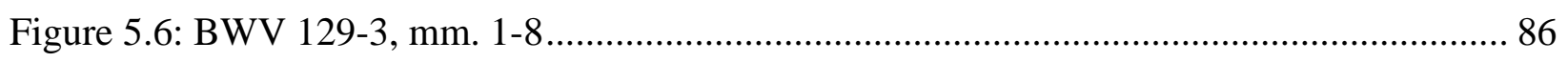

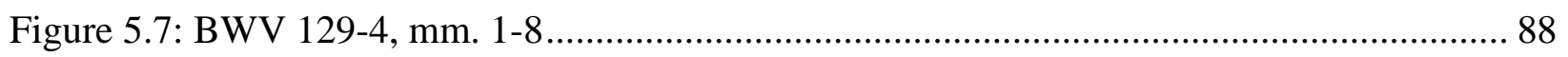

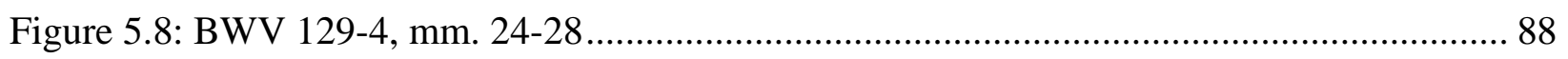

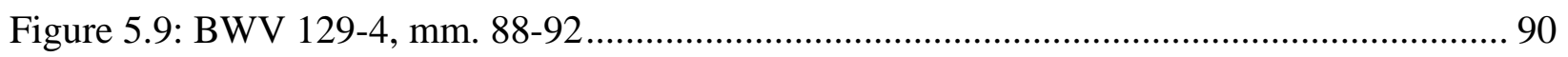

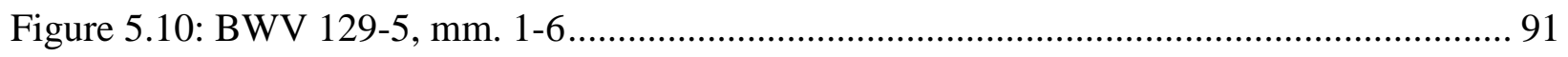

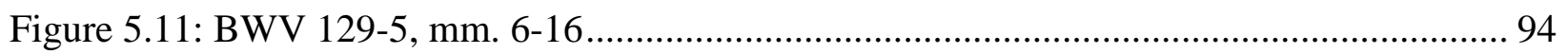




\section{List of Tables}

Table 2.1: Known Performance History of BWV 194 ............................................................ 14

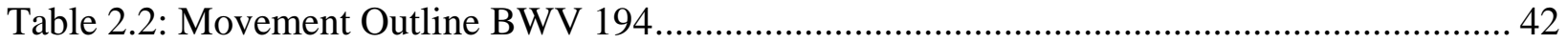

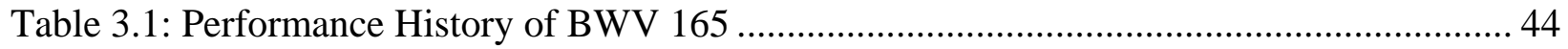

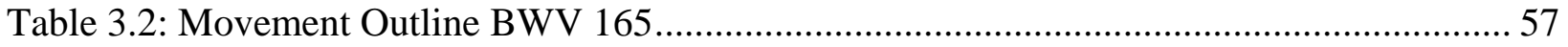

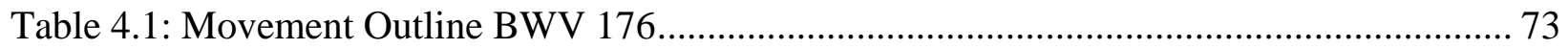

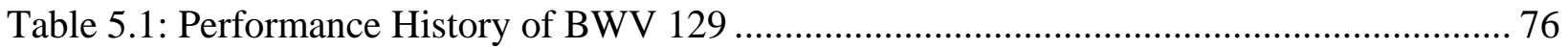

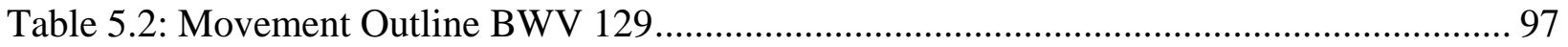

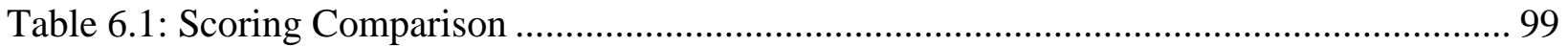

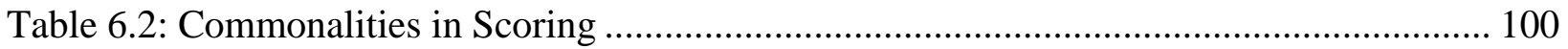

Table 6.3: Performance/Compositional History Comparison................................................ 102

Table 6.4: Libretto Comparison .......................................................................................... 105

Table 6.5: Detail of Each Movement Comparison .............................................................. 108 


\section{Dedication}

This Research Project is dedicated to my beloved life-partner David Goldstein, my parents Bob and Wanda Johnson, my mother-in-law Rochelle Goldstein, and my dear advisors Kathleen Shannon and Mary Ferer. I am so fortunate to be surrounded by a wise, kind, and unconditionally compassionate community. This document could not have been completed without their loving support and encouragement. 


\section{Chapter 1: Introduction and Selected Historical Background}

\section{Cantatas and Bach}

Closely related to opera and oratorio, cantatas began in Italy as a "lyrical counterpart” to the other dramatic genres. Entering into neighboring countries in the seventeenth century, the genre rose to a significant point in Protestant Germany as church cantatas. ${ }^{1}$ According to his obituary, written by Carl Philipp Emanuel Bach and Johann Friedrich Agricola, J. S. Bach wrote five cycles of cantatas for the entire church year - called Jahrgänge (plural), or Jahrgang (singular), literally “annual series” - for the churches in Leipzig between 1723 and 1750; however, only three cycles have survived the years virtually complete. ${ }^{2}$ Bach's cantatas of this period represent some of the most significant musical works of Western music’s sacred repertoire. The cantatas also present a unique look into the philosophical/spiritual mind of Bach. Even though the theological focus for each liturgical day is annually the same, Bach created new cantatas each year, with different spiritual themes and musical forms.

Bach arrived in Leipzig during May of 1723, to assume the role of Cantor and Music Director for the city. He would serve as music director for Leipzig's four churches and teacher for the students of St. Thomas's School. One can imagine this was a challenging situation for him. He was coming to a new vibrant city, joined by his wife and children, into a situation where he was expected to "bolster the attractiveness and reputation of the city, which was well-known as a center of trade and learning.”3 He had to begin successfully, and, of course, he did. Bach

\footnotetext{
${ }^{1}$ Alfred Dürr, The Cantatas of J. S. Bach: With Their Librettos in German-English Parallel Text, trans. Richard D. P. Jones (Oxford: Oxford University Press, 2005), 3.

2 Ibid., 11; Robin A. Leaver, “Jahrgang,” In Oxford Composer Companions: J. S. Bach, ed. Malcolm Boyd (Oxford: Oxford University Press, 1999), 245.

${ }^{3}$ Christoph Wolff, Johann Sebastian Bach: The Learned Musician (New York: W. W. Norton \& Company, Inc., 2000), 238.
} 
began his tenure in Leipzig, on May 30, 1723, the First Sunday after Trinity, with a performance of the cantata Die Elenden sollen essen (The poor shall eat), BWV 75. ${ }^{4}$ The Leipzig chronicle, Acta Lipsiensium academic, reported about that Sunday’s music and Bach’s appointment:

On the 30th of the same, the First Sunday after Trinity, the new Cantor and Director of the Collegium musicum Mr. Johann Sebastian Bach, who has come here from the princely court at Cöthen, performed his first music, with good applause. $^{5}$

Beginning with his first Sunday in Leipzig, May 30, 1723, Bach sought to present a piece of original concerted music - a cantata - on each Sunday and feast day of the ecclesiastical year, except for the Sundays that were part of the penitential seasons of Advent and Lent. During Advent and Lent, concerted music was typically not programmed. ${ }^{6}$ Since the First Sunday after Trinity was the beginning of Jahrgang I and the successive Jahrgänge, Trinity Sunday occurred at the end of the annual cycle. The cantatas performed in Leipzig on Trinity Sundays are the subject of this project. Qualities of each Jahrgang, during which the Trinity Sunday cantatas were first performed, will be discussed in the individual cantatas’ respective chapters.

\section{Trinity Sunday and Scripture}

The focus of Trinity Sunday, the Sunday immediately following Pentecost, was to honor the Holy Trinity, "the central doctrine of the Christian religion... that in the unity of the Godhead there are Three Persons, the Father, the Son, and the Holy Spirit, these Three Persons being truly distinct from one another."7

\footnotetext{
${ }^{4}$ Dürr, The Cantatas of J. S. Bach: With Their Librettos in German-English Parallel Text, 381

${ }^{5}$ Ibid., 384.

${ }^{6}$ Christoph Wolff, Johann Sebastian Bach: The Learned Musician (New York: W. W. Norton \& Company, Inc., 2000), 253-254.

${ }^{7}$ George Joyce, "The Blessed Trinity," The Catholic Encyclopedia, Vol. 15, (New York: Robert Appleton Company, 1912), http://www.newadvent.org/cathen/15047a.htm (accessed September 14, 2010). Although historically, Pentecost is a related to the Jewish harvest festival of Shavuot (God's giving the Ten Commandments to Moses), for Christians, Pentecost also commemorates the descent of the Holy Spirit on Christ's disciples following
} 
The Epistle scripture for Trinity Sunday was Romans 11:33-36 ${ }^{8}$ :

O the depth of the riches and wisdom and knowledge of God! How unsearchable are his judgements and how inscrutable his ways! "For who has known the mind of the Lord? Or who has been his counsellor? Or who has given a gift to him, to receive a gift in return?” For from him and through him and to him are all things. To him be the glory for ever. Amen. ${ }^{9}$

The Gospel scripture was John 3:1-15:

\section{Nicodemus Visits Jesus}

Now there was a Pharisee named Nicodemus, a leader of the Jews. He came to Jesus by night and said to him, "Rabbi, we know that you are a teacher who has come from God; for no one can do these signs that you do apart from the presence of God.” Jesus answered him, "Very truly, I tell you, no one can see the kingdom of God without being born from above." Nicodemus said to him, "How can anyone be born after having grown old? Can one enter a second time into the mother's womb and be born?” Jesus answered, “Very truly, I tell you, no one can enter the kingdom of God without being born of water and Spirit. What is born of the flesh is flesh, and what is born of the Spirit is spirit. Do not be astonished that I said to you, 'You must be born from above.' The wind blows where it chooses, and you hear the sound of it, but you do not know where it comes from or where it goes. So it is with everyone who is born of the Spirit.” Nicodemus said to him, "How can these things be?” Jesus answered him, “Are you a teacher of Israel, and yet you do not understand these things?

"Very truly, I tell you, we speak of what we know and testify to what we have seen; yet you do not receive our testimony. If I have told you about earthly things and you do not believe, how can you believe if I tell you about heavenly things? No one has ascended into heaven except the one who descended from heaven, the Son of Man. And just as Moses lifted up the serpent in the wilderness, so must the Son of Man be lifted up, that whoever believes in him may have eternal life."10

the Easter resurrection. The Trinity season marks the time in the church year between the season of Easter and the Advent of Jesus' birth.

${ }^{8}$ Dürr, The Cantatas of J. S. Bach: With Their Librettos in German-English Parallel Text, 371. Epistle scriptures are letters in the New Testament from Apostles to other Christians. Many of these epistles are attributed to Paul. In the Lutheran services for which Bach wrote his music, the Epistle reading would have taken place immediately before the Gospel reading.

${ }^{9}$ Oremus Bible Browser, "Oremus Bible Browser: Romans 11:33-36 (The New Revised Standard Version)," June 19, 2010, http://bible.oremus.org/ (accessed September 14, 2010).

${ }^{10}$ Oremus Bible Browser, "Oremus Bible Browser: John 3:1-15 (The New Revised Standard Version)," June 19, 2010, http://bible.oremus.org/ (accessed September 14, 2010). Gospel scriptures are writings in the New Testament that describe the life, death, and resurrection of Jesus. The four canonical gospels are Matthew, Mark, Luke, and John. The Gospel reading immediately preceded the presentation of the cantata for the day. The cantata was followed by one of the central parts of the Lutheran service: the sermon. 
Scholars are aware of four extant cantatas that Bach presented on Trinity Sunday: BWV 194, 165, 176, and 129. Two of the cantatas, BWV 165 and 176, were directly based on the scripture readings as described above; BWV 129 was based on a more general hymn in praise of the Holy Trinity. BWV 194 mentions the Holy Trinity in the middle movements of the cantata, but it was not based on the Trinity Sunday scripture readings, nor is the Holy Trinity this cantata's main theological focus. The scripture on which BWV 194 was based and the hymn on which BWV 129 was based and will be discussed more fully in Chapters 2 and 5, respectively.

Cantatas have not always been known by that name. Bach only rarely used that particular term; instead, he preferred concerto, Stück (piece), or simply Musik. It was not until the $19^{\text {th }}$ century, that Phillip Spitta and the editors of the Bach-Gesellschaft (the society that produced the first collected work of Bach) used the term "cantata” to refer to Bach's sacred works, as well as the similar works of his "contemporaries, and predecessors." ${ }^{11}$ By whatever name that they have been called, these concerted vocal pieces have long been known as “'sermon music' that sought to teach and persuade the listener." Placed between the Gospel reading and the Sermon in the Lutheran services, these compositions were given a prime spot to teach the worshipers, according to the day's lessons. ${ }^{12}$

Bach took the responsibility of creating musical compositions for this place in worship seriously, as can clearly be seen in his extraordinarily insightful joining of sacred music and text. One can also see Bach’s strong commitment to nurturing his own personal faith by examining

\footnotetext{
${ }^{11}$ Konrad Küster, “Cantata,” In Oxford Composer Companions: J. S. Bach, ed. Malcolm Boyd (Oxford: Oxford University Press, 1999), 82

${ }^{12}$ Melvin P. Unger, Handbook to Bach's Sacred Cantata Texts: An Interlinear Translation with Reference Guide to Biblical Quotations and Allusions (Lanham, MD: Scarecrow Press, Inc., 1996), xi.
} 
his own Bible commentary, which included the full text of scriptures. ${ }^{13}$ In the dedicatory epistle of the Bible volumes, the commentator, Abraham Calov, gives "an exposition of the doctrine of Scripture: 'Thus the Scriptures function as the sole authority for the church, not merely by means of using Scriptural words and phrases in doctrinal statements, but by believing, using, and living its message, which is divine truth itself." "14 The markings in the commentary show that the texts have been studied consistently by Bach, with "underlining, corrections, and marginalia [that] point to [their] continued use over a period of time;" however, the condition of the Bible volumes also indicates that they been preserved with attentive care. ${ }^{15}$ Bach used this Bible commentary regularly in his life and work, but treasured it as well. The Bible "provides strong evidence that Bach took keen interest in theological study and, hence, would have regarded the church cantata as a significant medium for theological proclamation.”16 The proof of Bach’s theological inquiry does not come as a surprise to those who study Bach's compositions, either as scholars or performers. Among those who are well-acquainted with his music, Bach is informally known as the "fifth evangelist." 17

Based on more than the scripture of the day or a general teaching about God, Bach’s cantatas contain deep layers of direct scripture-verse allusions as well as more general conceptual scriptural allusions (such as verbal images of the "Good Shepherd," "flock,” or "The

${ }^{13}$ Robin A. Leaver, J. S. Bach and Scripture: Glosses from the Calov Bible Commentary (St. Louis: Concordia Pub. House, 1985). For further investigation into this avenue of study, please refer to the other sources by Leaver cited in the bibliography.

${ }^{14}$ Leaver, J. S. Bach and Scripture: Glosses from the Calov Bible Commentary, 161.

${ }^{15}$ Ibid., 24.

${ }^{16}$ Unger, Handbook to Bach's Sacred Cantata Texts: An Interlinear Translation with Reference Guide to Biblical Quotations and Allusions, xii; Richard L. Jeske, "Bach as Biblical Interpreter,” In The Universal Bach: Lectures Celebrating the Tercentenary of Bach's Birthday (Philadelphia: American Philosophical Society, 1986), 84.

${ }^{17}$ Mary Ferer, "Pre-Leipzig Cantatas," Class lecture, Music 791: The Music of J. S. Bach and Musical Life in Eighteenth-Century Germany, West Virginia University, Morgantown, WV, 2009. 
Light.”). ${ }^{18}$ This extra layer of spiritual teaching was easily communicated to those of Bach’s congregations, who, like their Christian contemporaries, were highly literate, scripturally. ${ }^{19} \mathrm{~A}$ table of scriptural allusions and translations for each movement of the Trinity Sunday cantatas can be found in the Appendix of this document.

\section{Statement of Topic and Procedure}

The focus of this project is on the four extant Trinity Sunday cantatas that Bach presented during his tenure as Cantor and Music Director for the city of Leipzig: Höchsterwünschtes Freudenfest, BWV 194; O heilges Geist- und Wasserbad, BWV 165; Es ist ein trotzig un verzagt Ding, BWV 176; and Gelobet sei der Herr, BWV 129. In this document, the four cantatas are examined individually and then compared with one another, according to specific criteria and procedures developed for this study. Specific attention is given to the philosophical/spiritual themes that Bach brings out in these works about the Holy Trinity: God, the Father, Son, and Holy Spirit. The variety of perspectives employed in this document forms a unique examination of the four Trinity Sunday cantatas that has not previously been seen in Bach scholarship.

This study seeks to answer the following questions:

1. From what musical and textual material did Bach compose his Trinity Sunday cantatas?

2. How do the components and messages of the Trinity Sunday cantatas compare with one another?

3. How did Bach use the musical and textual components of the cantatas to communicate his intended theological/philosophical messages?

\footnotetext{
${ }^{18}$ Unger, Handbook to Bach's Sacred Cantata Texts: An Interlinear Translation with Reference Guide to Biblical Quotations and Allusions, xii.

${ }^{19}$ Michael Marissen, "Historically Informed Rendering of the Librettos from Bach's Church Cantatas," In Music and Theology: Essays in Honor of Robin A. Leaver (Lanham, MD: Scarecrow Press, 2007), 117.
} 
In answer to these questions, the four Trinity Sunday cantatas were examined using the most current scholarship available, by the following points of comparison:

- Movement Layout

- Vocal/Instrumental Forces

- Source Material and Historical Details

- Libretto

- Compositional Devices

- Bach’s Overall Philosophical Focus

To organize this study, the chapters featuring the four cantatas and the comparison between the compositions were ordered by the date of their first performances in Leipzig and divided into the following four subsections:

- Scoring

- Performance/Compositional History

- Libretto

- Detail of Each Movement 


\section{Limitations}

As the four cantatas were examined, the writer engaged in a significant amount of theoretical analysis. For an example, unusual chord progressions were noted and particularly significant motivic passages were highlighted as the cantatas' compositional devices were explored; however, a complete theoretical analysis was not included as part of this work. Since Joshua Rifkin’s 1981 presentation to the American Musicological Society in Boston, a significant amount of scholarly debate has taken place regarding the number of instrumentalists/singers Bach intended to have performing his music. Rifkin proposed that oneto-a-part was the most fitting personnel assignment for what Bach wanted for a large amount of his music. Following his paper's presentation in Boston, disciples lined up behind Rifkin to support him and detractors faced-off against him. The discussion of this element of performing practices of Bach's music will not be included in this project, although a sampling of sources have been included in the bibliography for those interested in further study on the subject.

\section{Translations}

Unless otherwise noted, the word-for-word German-to-English translations presented in the document are from Melvin P. Unger’s Handbook to Bach's Sacred Cantata Texts: An Interlinear Translation with Reference Guide to Biblical Quotations and Allusions; however, the translations of the cantata titles are from Oxford Composer Companions: J. S. Bach, edited by Malcolm Boyd. Richard D. P. Jones's translations from Alfred Dürr's The Cantatas of J. S. Bach: With Their Librettos in German-English Parallel Text were also used in a few instances when connected to specific commentary by Dürr. As part of Unger’s translations, parentheses ( ) surround words that have been added to the English translations for clarity. An additional line of 
text is sometimes added following the word-for-word translation, because, at times, German translations make little sense when the original word order remains intact with the English phrase. Unger has rearranged the word order in his English translations within the parentheses to make the phrases more understandable to English-speaking audiences.

\section{Bibliography}

The study of Bach's cantatas is blessed with a wealth of sources in print and on the Internet about these masterpieces. Of particular note are the following exceptional authors whose works, among other excellent sources of scholarship, were used throughout this study: Carol K. Baron, Johann Christian, Alfred Dürr, Stephen Daw, David Humphreys, Konrad Küster, Robin A. Leaver, Aryeh Oron, David Schulenberg, Hans-Joachim Schulze, Charles Stanford Terry, Melvin P. Unger, W. Gillies Whittaker, and Christoph Wolff. 


\section{Chapter 2: Höchsterwünschtes Freudenfest, BWV 194}

Chapter 2 describes the twelve-movement Höchsterwünschtes Freudenfest (Much awaited joyful feast), BWV 194. Highlights of this chapter include the history of the cantata's musical and textual development from congratulatory cantata to organ/church consecration cantata to Trinity Sunday cantata; scholarly associations made between dance forms / instrumental compositions and the cantata's arias and choruses; and reference made to many of J. S. Bach’s spiritually insightful realizations of sacred text through sacred music.

\section{Scoring}

Höchsterwünschtes Freudenfest, BWV 194, is scored for soprano, tenor, and bass soloists; a four-part chorus; and an orchestra of three oboes, bassoon, two violins, viola, organ, and basso continuo. ${ }^{1}$ The movements take the following form:

Part I

Mvmt. 1 - Chorus: SATB choir; oboes I-III, bassoon, strings, and basso continuo; B-flat major; alla breve, three-four, and alla breve time signatures

Mvmt. 2 - Recitativo: Bass solo; basso continuo; B-flat major; common time signature

Mvmt. 3 - Aria: Bass solo; oboe I, strings, and basso continuo; B-flat major; twelve-eight time signature

Mvmt. 4 - Recitativo: Soprano solo; basso continuo; G minor and E-flat major; common time signature

Mvmt. 5 - Aria: Soprano solo; strings and basso continuo; E-flat major; alla breve time signature

\footnotetext{
${ }^{1}$ David Humphreys, "Höchsterwünschtes Freudenfest," in Oxford Composer Companions: J. S. Bach, ed. Malcolm Boyd (Oxford: Oxford University Press, 1999), 221; Johann Sebastian Bach, Höchsterwünschtes Freudenfest, BWV 194, ed. Frieder Rempp, Neue Ausgabe sämtlicher Werke, ser. 1, vol. 31, Kantaten (Kassel, Germany: Bärenreiter, 1987), 236-259.
} 
Mvmt. 6 - Chorale: SATB choir; oboes I-III, bassoon, strings, and basso continuo (voice parts doubled by instruments, except for oboe III, which is independent from the voices due to the range of the instrument); B-flat major; common time signature

Part II

Mvmt. 7 - Recitativo: Tenor solo; basso continuo; F major and C minor; common time signature

Mvmt. 8 - Aria: Tenor and basso continuo; G minor; common time signature

Mvmt. 9 - Recitativo Duetto: Soprano and Bass soloists; basso continuo; B-flat major and F major; common time signature

Mvmt. 10 - Aria: Soprano and Bass soloists; oboe I and II, and basso continuo; F major; three-four time signature

Mvmt. 11 - Recitativo: Bass soloist and basso continuo; B-flat major; common time signature

Mvmt. 12 - Choral: SATB choir; oboes I-III, bassoon, strings, and basso continuo (voice parts doubled by instruments, except for oboe III, which is independent from the voices due to the range of the instrument); B-flat major; three-four time signature

\section{Performance/Compositional History}

Höchsterwünschtes Freudenfest was first performed on November 2, 1723, in Störmthal, a town approximately $19 \mathrm{~km}$ or 12 miles southeast of Leipzig by car. ${ }^{2}$ For this performance, the composition served as an organ/church building consecration cantata for the restored organ and renovated church at Störmthal. ${ }^{3}$ In addition to creating and presenting the consecration cantata, Bach also served the church in another very familiar role: as the advisor on the organ restoration project. Throughout his life, Bach was highly regarded as an organ examiner involved in many

\footnotetext{
${ }^{2}$ W. Gillies Whittaker, The Cantatas of Johann Sebastian Bach: Sacred and Secular, vol. 1 (London: Oxford University Press, 1959), 264-265; Google, "Störmthal, Grosspösna, Deutschland to Leipzig, Deutschland," Google Maps, http://maps.google.com/ (accessed August 25, 2010).

${ }^{3}$ Dürr, The Cantatas of J. S. Bach: With Their Librettos in German-English Parallel Text, 719-720; Stephen Daw, The Music of Johann Sebastian Bach, the Choral Works (Rutherford, NJ: Fairleigh Dickinson University Press, 1981), 92.
} 
organ design and restorations projects. ${ }^{4}$ If one travels to Germany today, one can still hear the organ, originally built by Zacharias Hildebrandt, at the village church in Störmthal, with the same stop list as existed when Bach examined the organ in 1723. The organ was most recently restored in $1934 .^{5}$

The cantata was performed in Leipzig, seven months later, on Trinity Sunday, June 4, 1724, the last Sunday of Jahrgang I. On that Sunday, BWV 194 was paired with O heilges Geistund Wasserbad, BWV $165 .{ }^{6}$ With this pairing, Bach completed his first annual cycle of cantatas, programming two cantatas or a two-part cantata for each Sunday of the church year (excluding Advent and Lent) between May 30, 1723 and June 4, 1724. ${ }^{7}$ For this cycle, one cantata was performed before the hour-long sermon; one was performed following the sermon. ${ }^{8}$ To accommodate the two cantatas, plus congregational music, spoken liturgy and an hour-long sermon, the typical Lutheran service in Leipzig lasted between three and four hours. ${ }^{9}$ John Eliot Gardiner suggests that only the first six movements were used on the Trinity Sunday performances. ${ }^{10}$ BWV 194 was also performed on Trinity Sundays, June 16, 1726 and May 20, 1731. The 1726 version of the cantata shows a change in movement order, rescoring of two arias, and the replacement of one oboe part with an obbligato organ. ${ }^{11}$ This version of the work is

${ }^{4}$ Wolff, Johann Sebastian Bach: The Learned Musician, 142-143.

${ }^{5}$ Dürr, The Cantatas of J. S. Bach: With Their Librettos in German-English Parallel Text, 719; Loft Recordings, "Störmthal, Germany: Hildebrandt organ (1723)," The Gothic Catalog. http://www.gothiccatalog.com/St_rmthal_Germany_Hildebrandt_organ_1723_s/884.htm (accessed December 20, 2009).

${ }^{6}$ BWV 165 will be discussed in Chapter 3 of this study.

${ }^{7}$ Wolff, Johann Sebastian Bach: The Learned Musician, 254, 270-273.

${ }^{8}$ Ibid., 269.

9 Tanya Kevorkian, “The Reception of the Cantata during Leipzig Church Services, 1700-1750,” in Bach's Changing World: Voices in the Community, ed. Carol K. Baron (Rochester, NY: University of Rochester Press, 2006), 176-177.

10 John Eliot Gardiner, "Bach Cantata Series: Cantatas for Trinity Sunday," Soli Deo Gloria, http://www.solideogloria.co.uk/recordings/bach_cantatas.cfm (accessed August 19, 2010).

${ }^{11}$ Humphreys, "Höchsterwünschtes Freudenfest," 221. 
published in the Neue Bach Ausgabe as BWV 194, directly following the 1723 version of the cantata. $^{12}$

As was typical of many of the cantatas of Jahrgang I, Bach based BWV 194 on some of his previously-composed works. ${ }^{13}$ The source of the original material extends back to the period of his service as Capellmeister to the Prince of Anhalt-Cöthen (1717-1723). The specific performance date of the original material is uncertain. ${ }^{14} \mathrm{~A}$ few extant instrumental parts give a sketchy picture of the original work; however, it was clearly a secular congratulatory cantata, lacking the chorales that were present in the 1723 version (mvmts. 6 and 12). The early version also contained different recitatives than the 1723 composition, and a “dance-like finale.” Since no vocal parts have survived, the libretto for this work is unknown. ${ }^{15}$ The preserved music has been published in the Neue Bach Ausgabe as BWV 194a. ${ }^{16}$ The number of verified performances of this work is significant. Alfred Dürr hypothesizes that the numerous revisions and revivals of this work lead one to believe that Bach may have performed his cantatas more frequently than we can pinpoint today. ${ }^{17}$

${ }^{12}$ Bach, Höchsterwünschtes Freudenfest, BWV 194, 236-259.

${ }^{13}$ Wolff, Johann Sebastian Bach: The Learned Musician, 269.

${ }^{14}$ Ibid., 187.

${ }^{15}$ Dürr, The Cantatas of J. S. Bach: With Their Librettos in German-English Parallel Text, 719.

${ }^{16}$ Johann Sebastian Bach, BWV 194a, ed. Alfred Dürr, Neue Ausgabe sämtlicher Werke, ser. 1, vol. 35, Festmusiken für die Fürstenhäuser von Weimar, Weißenfels und Köthen (Kassel, Germany: Bärenreiter, 1987).

${ }^{17}$ Dürr, The Cantatas of J. S. Bach: With Their Librettos in German-English Parallel Text, 719. 
Table 2.1: Known Performance History of BWV 194

\begin{tabular}{r|c|c|c|c|c} 
BWV & BWV 194a & BWV 194 & BWV 194 & BWV 194 & BWV 194 \\
\hline $\begin{array}{r}\text { Date of } \\
\text { performance }\end{array}$ & $\begin{array}{c}\text { 1717-1723 } \\
\text { (specific date } \\
\text { uncertain) }\end{array}$ & Nov 2, 1723 & June 4, 1724 & June 16, 1726 & May 20, 1731 \\
\hline $\begin{array}{r}\text { Location of } \\
\text { performance }\end{array}$ & Cöthen & Störmthal & Leipzig & Leipzig & Leipzig \\
\hline $\begin{array}{r}\text { Purpose of } \\
\text { cantata }\end{array}$ & $\begin{array}{c}\text { Secular } \\
\text { congratulatory } \\
\text { cantata }\end{array}$ & $\begin{array}{l}\text { Church/Organ } \\
\text { Consecration } \\
\text { cantata }\end{array}$ & Trinity Sunday \\
cantata & $\begin{array}{c}\text { Trinity Sunday } \\
\text { cantata }\end{array}$ & Trinity Sunday \\
cantata
\end{tabular}

\section{Libretto}

Even though the first performance of BWV 194 serves as a musical celebration and consecration of the organ and church building renovations at Störmthal, the surviving version of the work seems to be more focused on a church consecration rather than an organ consecration. The text never mentions the organ, but speaks extensively of the house of God. ${ }^{18}$ Except for the two chorales (mvmts. 6 and 12), the librettist for the cantata is anonymous. Some historians have theorized that Bach was the librettist as well as the composer for this work. ${ }^{19}$ The hymn writer of movement 6, Johann Heermann (1585-1647), was a poet laureate, trained theologian, university professor, and Lutheran pastor. Considered a very important chorale text writer for his time, Heermann's texts were used in over a dozen of Bach’s cantatas and other vocal works. ${ }^{20}$ Paul Gerhardt (1607-1675), the hymn writer for movement 12, was a Lutheran pastor who served in

\footnotetext{
${ }^{18}$ Dürr, The Cantatas of J. S. Bach: With Their Librettos in German-English Parallel Text, 719.

${ }^{19}$ Whittaker, The Cantatas of Johann Sebastian Bach: Sacred and Secular, vol. 1, 265.

${ }^{20}$ Aryeh Oron and Thomas Braatz, "Johann Heermann (Hymn-Writer),” Bach Cantatas Website, 2008, http://www.bach-cantatas.com/Lib/Heermann.htm (accessed September 17, 2010).
} 
Berlin and Lübben. ${ }^{21}$ A "bright star” among hymn writers, Gerhardt’s hymns “proclaim a strong trust in God's Word.”22 Bach used Gerhardt's texts in over twenty-five of his cantatas and vocal works. $^{23}$

Alfred Dürr succinctly describes the libretto of the cantata:

The text... celebrates the 'newly erected sanctuary' (no. 1), thanks God, and prays, 'Let this house be pleasing to You' (no. 2). It announces further that the dwelling of the Most High is full of radiance and will not be dimmed by night (no. 3). The fourth movement warns against human vanity and, since human power achieves nothing, prays for the church in the words of Solomon from I Kings 8:29, 'that Your eyes may be open towards this house,' and with reference to Hosea 14.2, 'so we will render the calves of our lips.' The fifth movement alludes to Isaiah 6.6f. in its prayer that we shall succeed in singing praises to the Lord. Part I concludes with the sixth and seventh verses of the hymn Treuer Gott, ich muß dir klagen by Johann Heermann (1630).

Part II brings no essentially new ideas, but it praises the divine Trinity (no. 7), whose presence alone brings blessing (no. 8). Textually, the most striking movement of all is the ninth, whose dialogue was perhaps suggested by a similar colloquy in the secular model, for its alternation between doubt (bass) and reassurance (soprano) is comparable with dialogues such as that of Fear and Hope in Cantata 66, which are likewise based on secular models. The other movements are concerned with the praise of God (in no. 10, after Psalm 34.8); and the work concludes with the ninth and tenth verses of Paul Gerhardt's hymn Wach auf, mein Herz, und singe (1647/53). ${ }^{24}$

The liturgical scripture readings for the November 2, 1723 service, during which BWV

194 was first performed, were the Epistle reading, Revelation 21:2-8 (“The New Jerusalem”), and the Gospel reading, Luke 19:1-10 (“The conversion of Zacchaeus”). ${ }^{25}$ The central point of

\footnotetext{
${ }^{21}$ NetHymnal, “Paul Gerhardt.” http://nethymnal.org/bio/g/e/gerhardt_p.htm (accessed September 17, 2010).

${ }^{22}$ Catherine Winkworth, “Christian Singers of Germany: Paul Gerhardt,” Calvin College Computer Science, http://www.ccel.org/ccel/winkworth/singers.gerhardt.html (accessed September 17, 2010); Harry Bartels, "Paul Gerhardt and J. S. Bach,” Evangelical Lutheran Synod, http://www.evangelicallutheransynod.org/publications/sentinel/2007/03/05Gerhard.html (accessed September 17, 2010).

${ }^{23}$ Aryeh Oron, “Paul Gerhardt (Hymn-Writer),” Bach Cantatas Website, 2009, http://www.bachcantatas.com/Lib/Gerhardt.htm (accessed September 17, 2010).

${ }^{24}$ Dürr, The Cantatas of J. S. Bach: With Their Librettos in German-English Parallel Text, 719-720.

${ }^{25}$ Ibid., 715.
} 
each scriptural text is God coming to dwell with humans, a perfect text for a service and a

cantata dedicating a new church building:

Revelation 21: 2-8

And I saw the holy city, the new Jerusalem, coming down out of heaven from God, prepared as a bride adorned for her husband. And I heard a loud voice from the throne saying, "See, the home of God is among mortals. He will dwell with them; they will be his peoples, and God himself will be with them; he will wipe every tear from their eyes. Death will be no more; mourning and crying and pain will be no more, for the first things have passed away.”

And the one who was seated on the throne said, "See, I am making all things new." Also he said, "Write this, for these words are trustworthy and true." Then he said to me, "It is done! I am the Alpha and the Omega, the beginning and the end. To the thirsty I will give water as a gift from the spring of the water of life. Those who conquer will inherit these things, and I will be their God and they will be my children. But as for the cowardly, the faithless, the polluted, the murderers, the fornicators, the sorcerers, the idolaters, and all liars, their place will be in the lake that burns with fire and sulphur, which is the second death." ${ }^{26}$

Luke 19:1-10

Jesus and Zacchaeus

He entered Jericho and was passing through it. A man was there named Zacchaeus; he was a chief tax-collector and was rich. He was trying to see who Jesus was, but on account of the crowd he could not, because he was short in stature. So he ran ahead and climbed a sycamore tree to see him, because he was going to pass that way. When Jesus came to the place, he looked up and said to him, "Zacchaeus, hurry and come down; for I must stay at your house today." So he hurried down and was happy to welcome him. All who saw it began to grumble and said, "He has gone to be the guest of one who is a sinner." Zacchaeus stood there and said to the Lord, "Look, half of my possessions, Lord, I will give to the poor; and if I have defrauded anyone of anything, I will pay back four times as much.” Then Jesus said to him, "Today salvation has come to this house, because he too is a son of Abraham. For the Son of Man came to seek out and to save the lost.,27

As was mentioned in the Introduction for this document, it was typical practice for librettists to include numerous scriptural allusions within their texts. Melvin P. Unger groups

\footnotetext{
${ }^{26}$ Oremus Bible Browser, "Oremus Bible Browser: Revelation 21:2-8 (The New Revised Standard Version)," June 19, 2010, http://bible.oremus.org/ (accessed September 17, 2010).

${ }^{27}$ Oremus Bible Browser, "Oremus Bible Browser: Luke 19:1-10 (The New Revised Standard Version)," June 19, 2010, http://bible.oremus.org/ (accessed September 17, 2010).
} 
Bach’s cantata text scriptural allusions into four areas (please refer to the Appendix for the cantata’s text translations and scriptural allusions):

1. literal biblical quotations

2. biblical paraphrases

3. allusions to specific biblical passages

4. allusions to general biblical themes or images ${ }^{28}$

Throughout this cantata's text, as stated previously, the focus is on the temple of God, a sanctified space to worship the Most High; however, the composition was also presented on Trinity Sunday. The most prominent references to the Holy Trinity are found in movement 6 , the final chorale movement of Part I, and movement 7, the opening tenor recitative of Part II. Even though most of the cantata text is centered on the consecrated building of worship, the two references to the Trinity were found in the heart of the cantata, the two central movements. Perhaps the prominent placement of these phrases strengthened Bach's resolve to revive the work on Trinity Sunday.

\section{Detail of Each Movement}

Several movements of the cantata seem to be based on orchestral suite movement forms, including the French overture, pastorale, gavotte, gigue, and minuet. Some scholars have theorized that the Störmthal cantata (1723), rather than being formed from a secular congratulatory cantata, was created from a purely instrumental piece, by dropping in new vocal parts. While several movements seem to strongly suggest the instrumental connection, the varying keys between each movement weaken that argument. (Typically, the movements within instrumental suites are in the same key. $)^{29}$ One of the movements that support the theory of

\footnotetext{
${ }^{28}$ Unger, Handbook to Bach's Sacred Cantata Texts: An Interlinear Translation with Reference Guide to Biblical Quotations and Allusions, xiv.

${ }^{29}$ Dürr, The Cantatas of J. S. Bach: With Their Librettos in German-English Parallel Text, 720.
} 
instrumental origin is movement 1 , a four-part choral piece, with three oboes, bassoon, strings and basso continuo, written in the style of the French overture. Dürr suggests that an original French overture instrumental composition might have been adapted for this movement of the cantata by inserting choral sections. This theory is based on the fact that the slow sections are performed by the instruments alone (except for a very brief passage from the choir in the final moments of the movement), and that the faster fugal middle section is performed by choir with only “partially independent instruments.”,30

This cantata is one of six extant Bach cantatas that make use the French overture style. "In each case, the Overture is the initial movement of the cantata, prompted by the liturgical ordering of the cantata as the first of a yearly cycle, the first of a season, the birth of Christ, or a general festive occasion.”31 The other cantatas of this group are O Ewigkeit, $d u$ Donnerwort (BWV 20) (First Sunday after Trinity, 1724); Nun komm, der Heiden Heiland (BWV 61) (First Sunday in Advent, 1714); In allen meinen Taten (BWV 97) (liturgical occasion unknown, 1734); Unser Mund sei voll Lachens (BWV 110) (Christmas, 1725); and Preise Jerusalem, den Herrn (BWV 119) (inauguration of Leipzig town council, 1723). ${ }^{32}$

In B-flat major, this movement begins with a stately instrumental section, with dotted rhythms typical of the French overture style. The second section is a brisk choral fugue (also typical of the French overture style) based on the motivic subject that sets the opening text. The choral sopranos begin on an appropriately high F5 for the text Höchsterwünschtes (Highest wished for). Setting the text Freudenfest (joy-feast), the voices extend the first syllable of the word with rising sequential melismas (Figure 2.1). The fact that the choral parts in this section

\footnotetext{
${ }^{30}$ Dürr, The Cantatas of J. S. Bach: With Their Librettos in German-English Parallel Text, 720.

31 Jeanne Swack, “A Comparison of Bach’s and Telemann's Use of the Overture as Theological Signifier,” Bach Perspectives 6 (2007): 100-101.

${ }^{32}$ Ibid., 100.
} 
mostly double the instruments supports the theory that the choral parts were dropped into an existing instrumental piece.

Figure 2.1: BWV 194-1, mm. 32-36 ${ }^{33}$

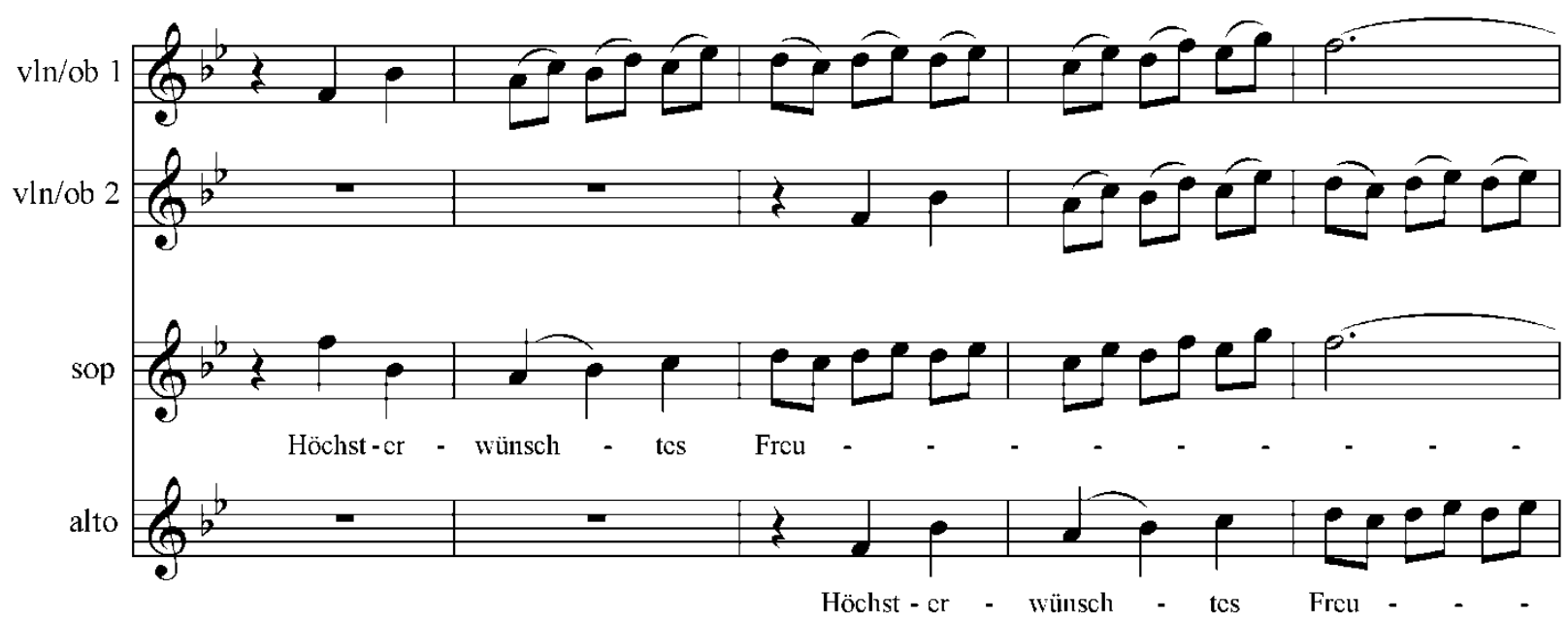

Following a full fugal setting of the remainder of the text im erbauten Heiligtume uns vergnügt begehen läßt (in this newly erected sanctuary let us gladly celebrate), a slow instrumental section recalls the opening section's musical material (the final piece of a three part French overture). This musical recapitulation is shortened from the opening section - fifteen measures as compared to the opening section's thirty-one measures. To bring the movement to a close, the chorus sings a final rousing Höchsterwünschtes Freudenfest, set to musical material from the slow sections of the movement. ${ }^{34}$

Movement 2, also in the key of B-flat major, is a recitative for bass soloist, with basso continuo. This movement was adapted for the Leipzig performance with sections written in lower tessituras than were indicated in the original version. In the Neue Bach Ausgabe edition of BWV 194, one finds the original notes of this recitative, regularly placed in the E4 to G4 range

\footnotetext{
${ }^{33}$ Bach, Höchsterwünschtes Freudenfest, BWV 194, 153.

${ }^{34}$ Whittaker, The Cantatas of Johann Sebastian Bach: Sacred and Secular, vol. 1, 266-267.
} 
(very high for a bass singer), along with Bach's lower-range note options, marked Ossia in a normal bass tessitura. ${ }^{35}$ Several of the movements in this cantata (most notably the soprano and bass parts in the opening movement, and other solo bass movements) contain parts written in similar extremely high ranges; however, Bach only provided optional lower sections for two movements in the cantata, both bass recitatives. Dürr suggests that the cantata's unusual ranges might stem from the cantata's connection to its secular origins. ${ }^{36}$ Secular music was tuned at a different pitch than sacred music. The secular Kammerton (chamber pitch) tuning was a step or even up to a minor third lower than the sacred Chorton (choir pitch) tuning, due to the fact that organs usually could not be tuned to Kammerton. ${ }^{37}$ The tessitura of this cantata's parts caused Bach to perform the cantata at tief-Kammerton (deep chamber pitch) when he revived the work in Leipzig in $1724 .{ }^{38}$ Stephen Daw notes that the high tessitura of the music was only a problem beginning at Leipzig, because the pitch of Störmthal organ was unusually low. ${ }^{39}$

This second movement of the cantata is a secco recitative, set with notes in the typical speech-like rhythmic and melodic patterns of recitatives. The vocal contour of this recitative highlights the text that reaches up to God in prayer, yet from the place of a humble servant of God. The first line of the text addresses the Divine with a rise up to Eb4 from F3, Unendlich großer Gott ([O] infinite great God). As a gesture of humility, the line in mm. 4-5 descends to F3 (the beginning note in the movement), und zum Gebete deiner Knechte! (And to-the prayers ofthy servants!). With a slight expansion in the rhythm compared to the surrounding notes, caused by a beat and a half of rests before the passage and eighth and sixteenth rests interspersed

\footnotetext{
${ }^{35}$ Bach, Höchsterwünschtes Freudenfest, BWV 194, 184.

${ }^{36}$ Dürr, The Cantatas of J. S. Bach: With Their Librettos in German-English Parallel Text, 720.

${ }^{37}$ Ibid., 953.

${ }^{38}$ Dürr, The Cantatas of J. S. Bach: With Their Librettos in German-English Parallel Text, 720.

${ }^{39}$ Daw, The Music of Johann Sebastian Bach, the Choral Works, 93.
} 
throughout the passage, one of the main points of the recitative is brought out, $\mathrm{Du}$, den kein Haus, kein Tempel faßt ([O] thou, whom no house, no temple can-contain) (Figure 2.2).

Figure 2.2: BWV 194-2, mm. 10-11 ${ }^{40}$

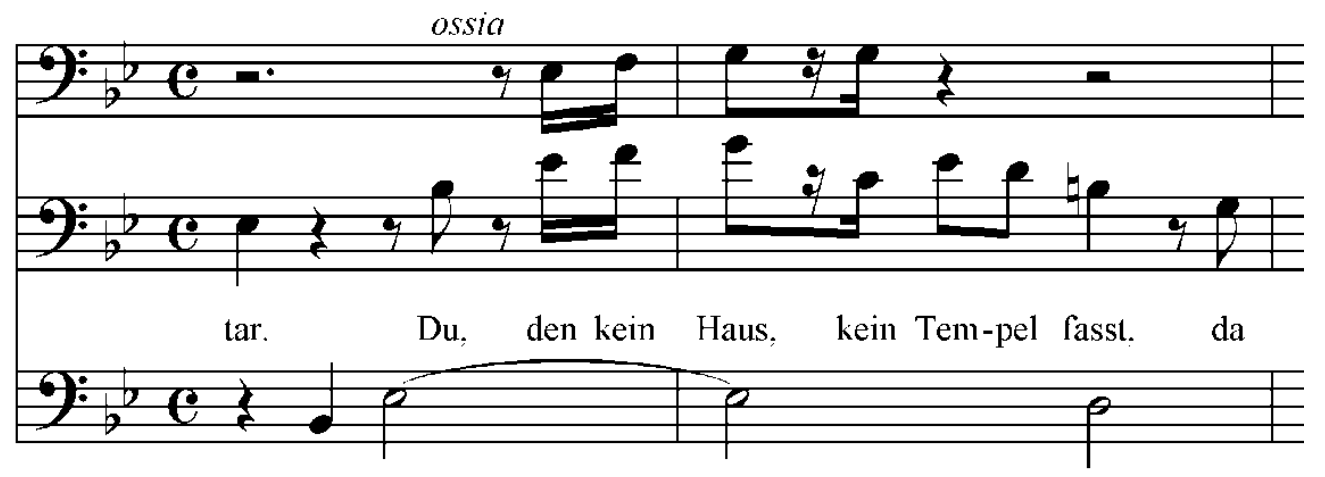

Finally, the request is made that the house be pleasing to God and that it serve as ein wahrer Gnadenstuhl (a true mercyseat), ein Frendenlicht (a light-of-joy). To highlight the Gnadenstuhl, Bach harmonizes the line with a surprising C major chord in the midst of the key of B-flat major (Figure 2.3). The C major chord serves as a secondary dominant for the V chord in B-flat major (F major), to which it resolves before concluding on a B-flat major chord.

Figure 2.3: BWV 194-2, mm. 14-16 ${ }^{41}$

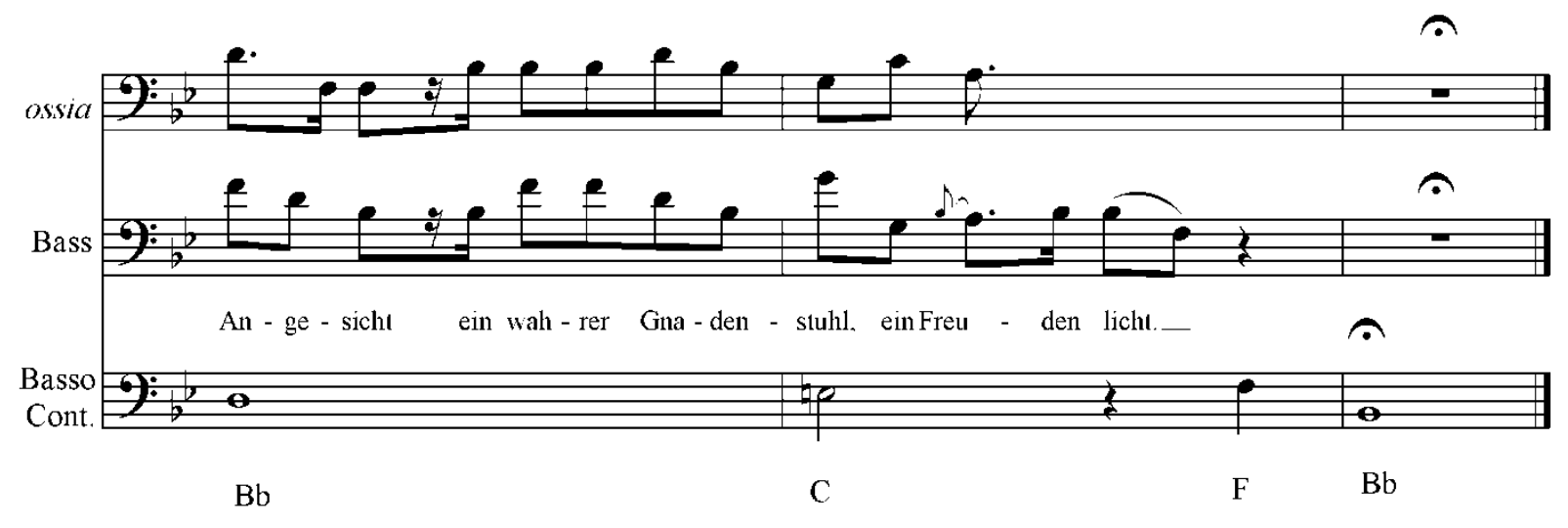

${ }^{40}$ Bach, Höchsterwünschtes Freudenfest, BWV 194, 184.

${ }^{41}$ Ibid., 185. 
The bass aria, movement 3, like movement 2, is written with a very high tessitura for the bass voice (C4-F4); however, no lower notes are provided for this movement. In the key of B-flat major, this movement is in 12/8 time, and is written in the style of a pastorale or siciliano. ${ }^{42}$ The instrumental accompaniment for this movement is oboe, strings, and basso continuo. In the 1726 version of the cantata, the oboe part was replaced with an obbligato organ. ${ }^{43}$ Whittaker suggests that the exceptionally full instrumental writing in this aria reflects on the piece's theorized instrumental composition beginnings. He also points to an unnecessary melismatic stress in m. 6 on the word in (in) as part of the text phrase Was des Höchsten Glanz erfüllt, wird in keine Nacht verhüllt (What the Highest One’s radiance does-fill shall in no night be-veiled or Whatever the Highest One fills with his radiance, shall never be veiled in night) as an example of a cantata movement that was sometimes awkwardly adapted from an instrumental composition. ${ }^{44}$ With a contrasting opinion, Daw suggests that the writing of this movement and the cantata is much more like Bach’s choral writing from Cöthen, rather than Bach’s purely instrumental compositions. ${ }^{45}$ Regardless of its possible antecedents, it is a beautiful movement -- lilting and sweet sounding. Even though some words may be improperly stressed by the musical setting, other words, such as erfüllt (does-fill) from the text phrase mentioned previously, Was des Höchsten Glanz erfüllt, wird in keine Nacht verhüllt (What the Highest-One’s radiance does-fill shall in no night be-veiled), are beautifully composed with very “filling” passages. In many of the instances of this word, Bach writes extended twinings of melismas, including a full measurelong melisma on erfüllt in m. 35 (Figure 2.4).

\footnotetext{
${ }^{42}$ Dürr, The Cantatas of J. S. Bach: With Their Librettos in German-English Parallel Text, 720; Whittaker, The Cantatas of Johann Sebastian Bach: Sacred and Secular, vol. 1, 267.

${ }^{43}$ Humphreys, "Höchsterwünschtes Freudenfest," 222.

${ }^{44}$ Whittaker, The Cantatas of Johann Sebastian Bach: Sacred and Secular, vol. 1, 267.

${ }^{45}$ Daw, The Music of Johann Sebastian Bach, the Choral Works, 93.
} 
Figure 2.4: BWV 194-3, mm. 34-35 ${ }^{46}$

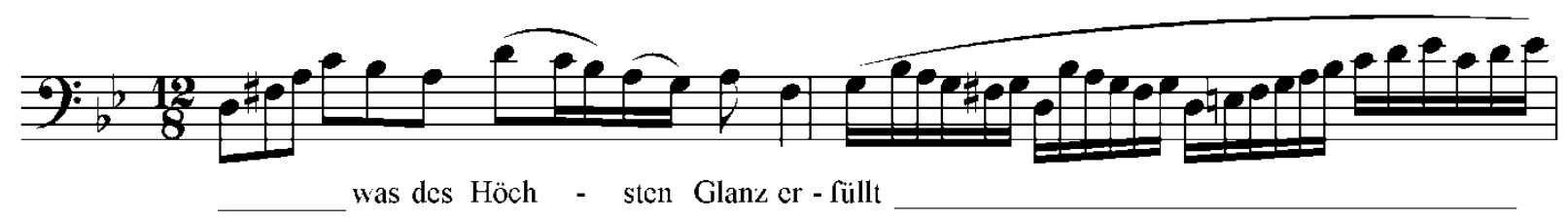

Movement 4 is a secco recitative for soprano with basso continuo. This movement breaks from the previous movements' key patterns of B-flat major, as it begins in G minor and ends in E-flat major. Harmonically, this movement serves as a bridge to the next movement, which is in E-flat major. The most notable text setting in this movement occurs in m. 15 as the core point of the movement's text is reached on the word Freude (joy) in the text phrase So legen wir in heilger Freude dir (Then lay we in holy joy for-thee). In this measure, on the word Freude, the movement's strict syllabic setting pattern changes to a short but “joyful” melismatic pattern (Figure 2.5).

Figure 2.5: BWV 194-4, m. $15^{47}$

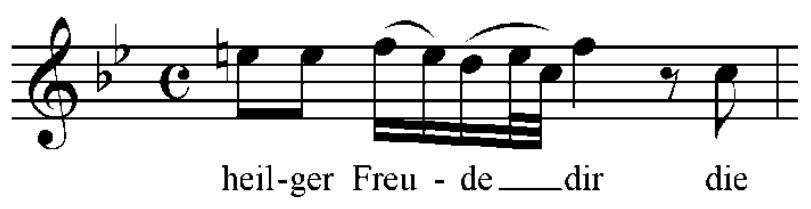

Movement 5, a soprano da capo aria with strings and basso continuo, is in the key of Eflat major, and has the rhythmic character of a gavotte. ${ }^{48}$ According to Whittaker, the extensive opening material of the violin 1 part, which is repeated by the soprano beginning in $\mathrm{m}$. 18 , is much more suited to the violin than to the voice, due to the quickly moving angular leaps in both

\footnotetext{
${ }^{46}$ Bach, Höchsterwünschtes Freudenfest, BWV 194, 190.

${ }^{47}$ Ibid., 194

${ }^{48}$ Humphreys, "Höchsterwünschtes Freudenfest," 222.
} 
parts. ${ }^{49}$ Two words stand out in this movement's text, both in terms of their textual imagery as well as their musical setting: Feuer and dringt (fire and penetrate) within the text phrase Und dein Feuer in uns dringt (And thy fire into us penetrate). Whether or not the instrumental music or the vocal music came first in the creation of this movement's music, Bach uses a figure throughout the movement, both in the voice and the violin parts, to paint a vivid aural image of dancing flames (Figure 2.6).

Figure 2.6: BWV 194-5, m. $28^{50}$

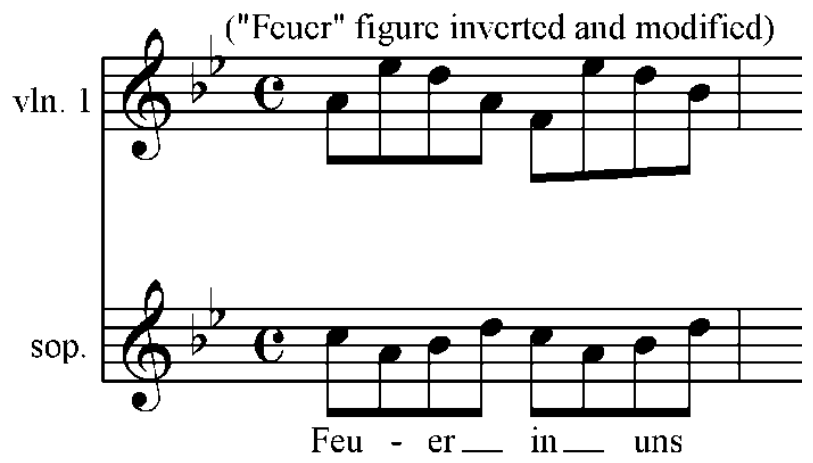

For the word dringt, Bach uses extended melismatic passages, often with dramatic rises in pitch, as the flames leap to penetrate every part of the soul (Figure 2.7).

Figure 2.7: BWV 194-5, mm. 39-43 ${ }^{51}$

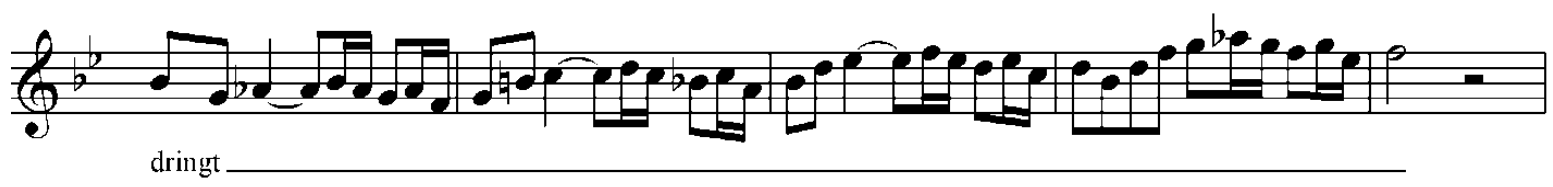

\footnotetext{
${ }^{49}$ Whittaker, The Cantatas of Johann Sebastian Bach: Sacred and Secular, vol. 1, 267.

${ }^{50}$ Bach, Höchsterwünschtes Freudenfest, BWV 194, 197.

${ }^{51}$ Ibid., 197-198.
} 
As is typical of the contrasting sections of da capo arias, the second portion of the aria moves to a related key (C minor) and new musical material is presented. The voice part retains its gavotte-like character; however, this section's text is set with no extended melismatic passages like those found in the first section of the aria. The most pronounced new musical element is given to the violin I part: sixteenth note flourishes that Whittaker describes as "illustrative of the flight of the seraphim [Figure 2.8].,52 The seraphim reference, a scriptural allusion of the movement's text, is drawn from Isaiah 6:1-7: "Above him stood the seraphim, each had six wings... And one called to another and said: "Holy, holy, holy is the Lord of hosts. ${ }^{, 53}$

Daß es auch in dieser Stunde

That it (might) also in this hour,

Wie in Esaiae Munde

As (it did) in Isaiah's mouth,

Seiner Wirkung Kraft erhält

Its (effective) power retain

Und uns heilig vor dich stellt.

And us holy before thee bring.

(And bring us sanctified before thee.). ${ }^{54}$

${ }^{52}$ Whittaker, The Cantatas of Johann Sebastian Bach: Sacred and Secular, vol. 1, 268.

${ }^{53}$ Unger, Handbook to Bach's Sacred Cantata Texts: An Interlinear Translation with Reference Guide to Biblical Quotations and Allusions, 677.

${ }^{54}$ Ibid. 
Figure 2.8: BWV 194-5, mm. 81-85

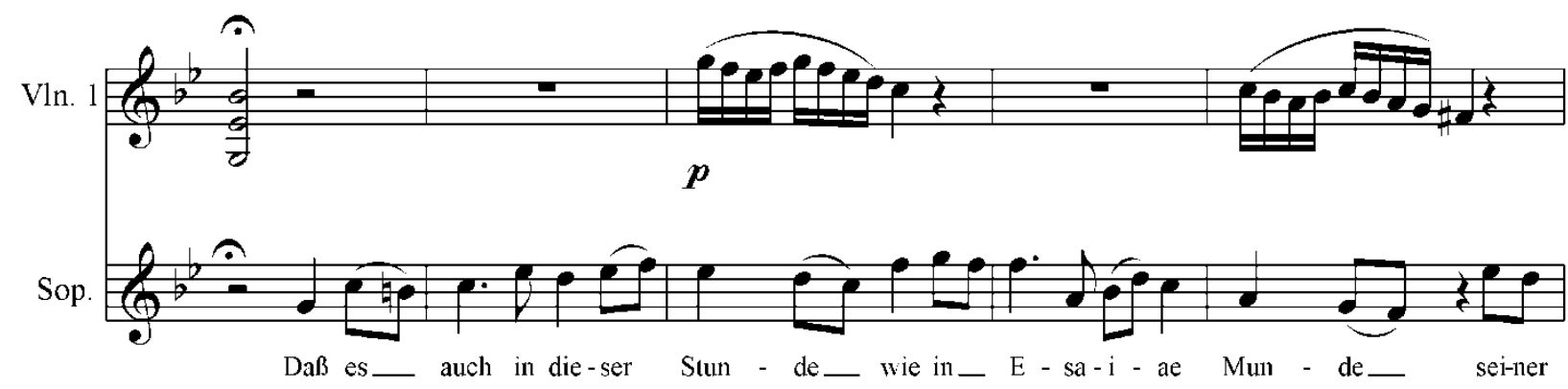

Movement 6 is the closing chorale for Part I, scored for four-part chorus with three oboes parts, strings, and basso continuo. In B-flat major, this movement sets the sixth and seventh stanzas of the hymn Treuer Gott, ich muss dir klagen (1630) by Johann Heermann. ${ }^{56}$ The instruments in this chorale simply double the voice parts, with one exception. Due to the compass of the instrument, the oboe 3 part is mostly written independent of the voice parts. ${ }^{57}$

Along with the seventh movement, the tenor recitative, this chorale most significantly mentions the Holy Trinity in its text. Except for these two movements, the Trinity is not mentioned anywhere in the cantata.

Heilger Geist ins Himmels Throne,

(O) Holy Ghost on heaven's throne,

Gleicher Gott von Ewigkeit

Equally God from (all) eternity

Mit dem Vater und dem Sohne,

With the Father and the Son,

(Coequal with the Father and the Son from all eternity,)

${ }^{55}$ Bach, Höchsterwünschtes Freudenfest, BWV 194, 201.

${ }^{56}$ Humphreys, "Höchsterwünschtes Freudenfest," 222.

${ }^{57}$ Dürr, The Cantatas of J. S. Bach: With Their Librettos in German-English Parallel Text, 716. 
Der Betrübten Trost und Freud!

Of-the sorrowing (the) comfort and joy!

(Comfort and joy of all the sorrowing!) $^{58}$

Perhaps the fact that the Holy Trinity is so prominent in the center-most movements of the cantata (or the final movement if the cantata is only performed with Part I), led to Bach's reviving the work for Trinity Sunday after its performance in Störmthal for the organ/church building dedication service. Even though many chorales in Bach's cantatas contain examples of highly expressive chromaticism and unexpected harmonic shifts that highlight key phrases of the texts, this chorale is set very plainly, with little chromaticism and no unusual harmonic changes.

Part II begins with a secco tenor recitative with basso continuo (movement 7). Beginning in F major and ending in C minor, this recitative's solo part is different musically from the previous recitatives in this cantata. The difference centers on the rather extensive melismatic passage in measure 2. After two words are sung in this cantata's typical syllabic pattern at the beginning of the recitative - Ihr Heiligen (Ye saints), the third word of the recitative is sung with an expansive melisma - erfreut (rejoice) (Figure 2.9).

Figure 2.9: BWV 194-7, mm. 1-2

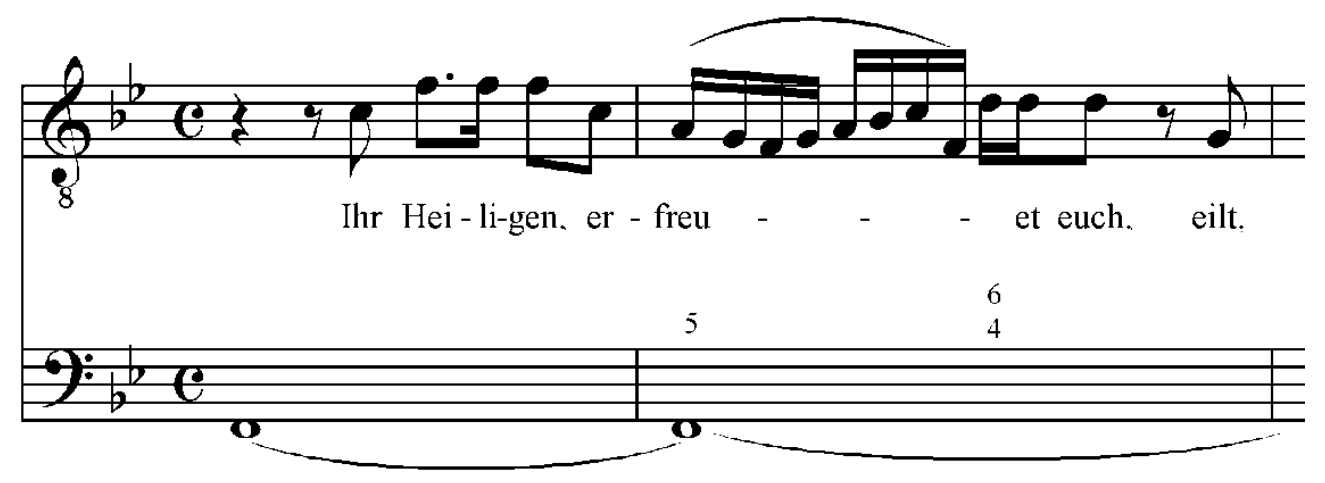

${ }^{58}$ Unger, Handbook to Bach's Sacred Cantata Texts: An Interlinear Translation with Reference Guide to Biblical Quotations and Allusions, 677-678.

${ }^{59}$ Bach, Höchsterwünschtes Freudenfest, BWV 194, 208. 
The remainder of the recitative returns to the syllabic presentation of the text, typical of the previous recitatives in the cantata. As stated in the description of movement 6 , this movement's text contains pronounced references to the Holy Trinity:

Ein Stand, so billig selig heißt, A station, which rightly blest is-called, (This station can rightly be called blessed,)

Man schaut hier Vater, Sohn und Geist. (We) behold here Father, Son, and Spirit. ${ }^{60}$

In addition to the Holy Trinity reference in these two lines, the text also refers to a place from which one can worship God: Ein Stand (A station). Since this composition originally was intended as church dedication, it is fitting that Bach calls attention to this phrase. He accomplishes this musical highlighting, by surrounding this text with the most vocal silence in the recitative (two and a half beats of rests before and after the phrase) (Figure 2.10).

Figure 2.10: BWV 194-7, mm. 10-13 ${ }^{61}$

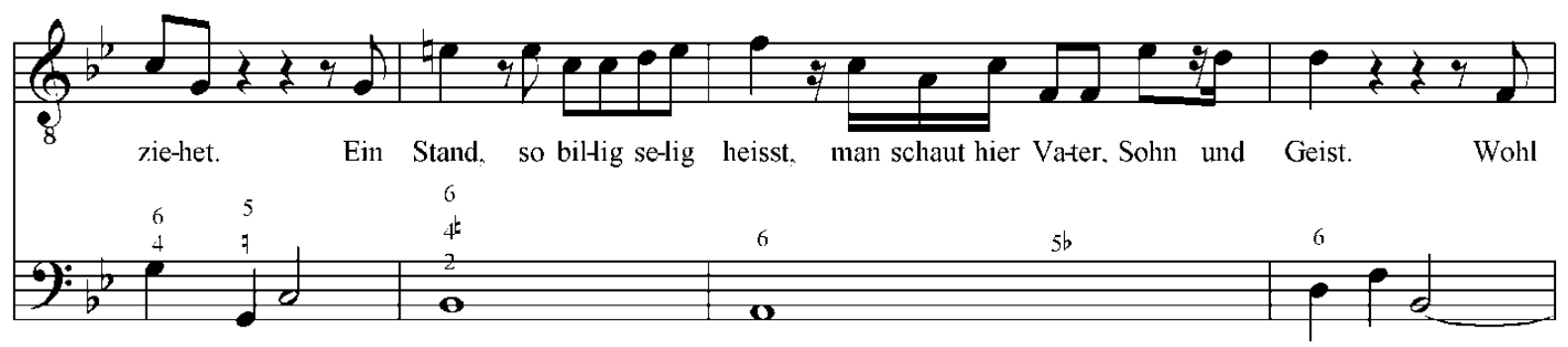

Movement 8, in the key of $\mathrm{G}$ minor, is a tenor aria accompanied with basso continuo in the style of a gigue. ${ }^{62}$ In this da capo aria, Bach makes a musical connection with the previous recitative's melismatic setting of erfreuen (rejoice) (movement 7) and the repeated melismatic

\footnotetext{
${ }^{60}$ Unger, Handbook to Bach's Sacred Cantata Texts: An Interlinear Translation with Reference Guide to Biblical Quotations and Allusions, 679.

${ }^{61}$ Bach, Höchsterwünschtes Freudenfest, BWV 194, 208.

${ }^{62}$ Dürr, The Cantatas of J. S. Bach: With Their Librettos in German-English Parallel Text, 720.
} 
settings of the word Freuden (as part of the phrase Freuden Ursprung [joy's fountainhead or joy’s source] [movement 8]). In addition to Freuden, Bach also brings out the text allein (alone) in this aria. The first two lines of the text which Bach sets in the first part of this da capo movement are as follows:

Des Höchsten Gegenwart allein

The Highest's presence alone

(Only the presence of the Most High)

Kann unsrer Freuden Ursprung sein.

Can our joy's (fountainhead) be.

(Can be the source of our joy. $)^{63}$

In the typical fashion of an aria, the text is repeated numerous times with different musical realizations. Most of the repetitions bring out Freuden through melismas (Figure 2.11), and one surprise high A4 approached from perfect fourth below (Figure 2.12).

Figure 2.11: BWV 194-8, mm. 29-30 ${ }^{64}$

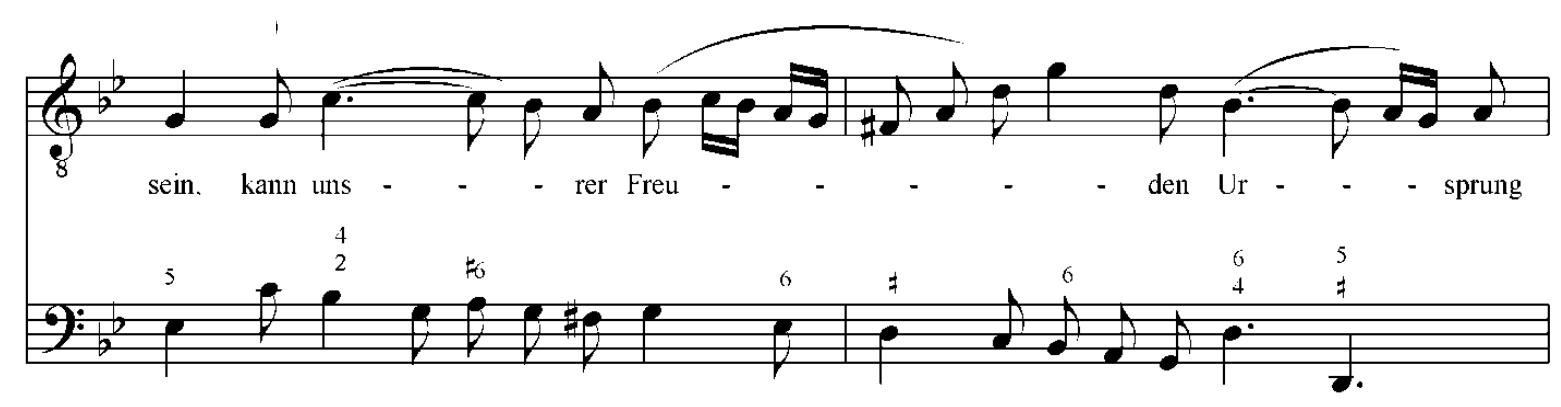

${ }^{63}$ Unger, Handbook to Bach's Sacred Cantata Texts: An Interlinear Translation with Reference Guide to Biblical Quotations and Allusions, 680.

${ }^{64}$ Bach, Höchsterwünschtes Freudenfest, BWV 194, 211 
Figure 2.12: BWV 194-8, mm. 21-23 ${ }^{65}$

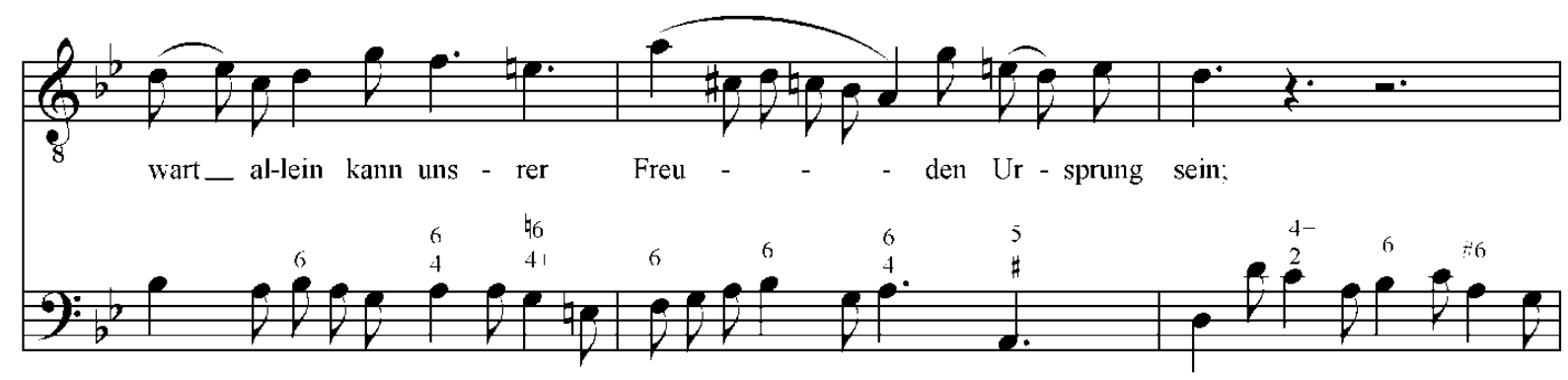

To change the emphasis of the textual phrase, Bach brings out allein in two passages. In the first passage, allein is emphasized by a high G4 approached from a major sixth below (Figure 2.13). In the second passage, allein is set with the most florid of melismas in this movement, rising to a high A4. A measure later, allein is again approached by a large interval from below; this time the interval is a minor sixth from G3 to E-flat4 (Figure 2.14).

Figure 2.13: BWV 194-8, mm. 16-17

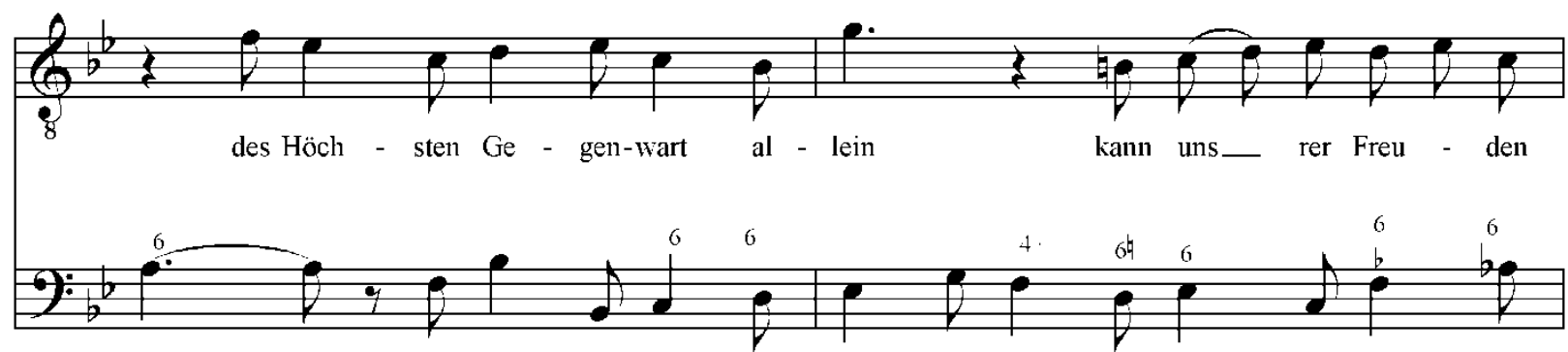

${ }^{65}$ Bach, Höchsterwünschtes Freudenfest, BWV 194, 210

${ }^{66}$ Ibid. 
Figure 2.14: BWV 194-8, mm. 24-27 ${ }^{67}$
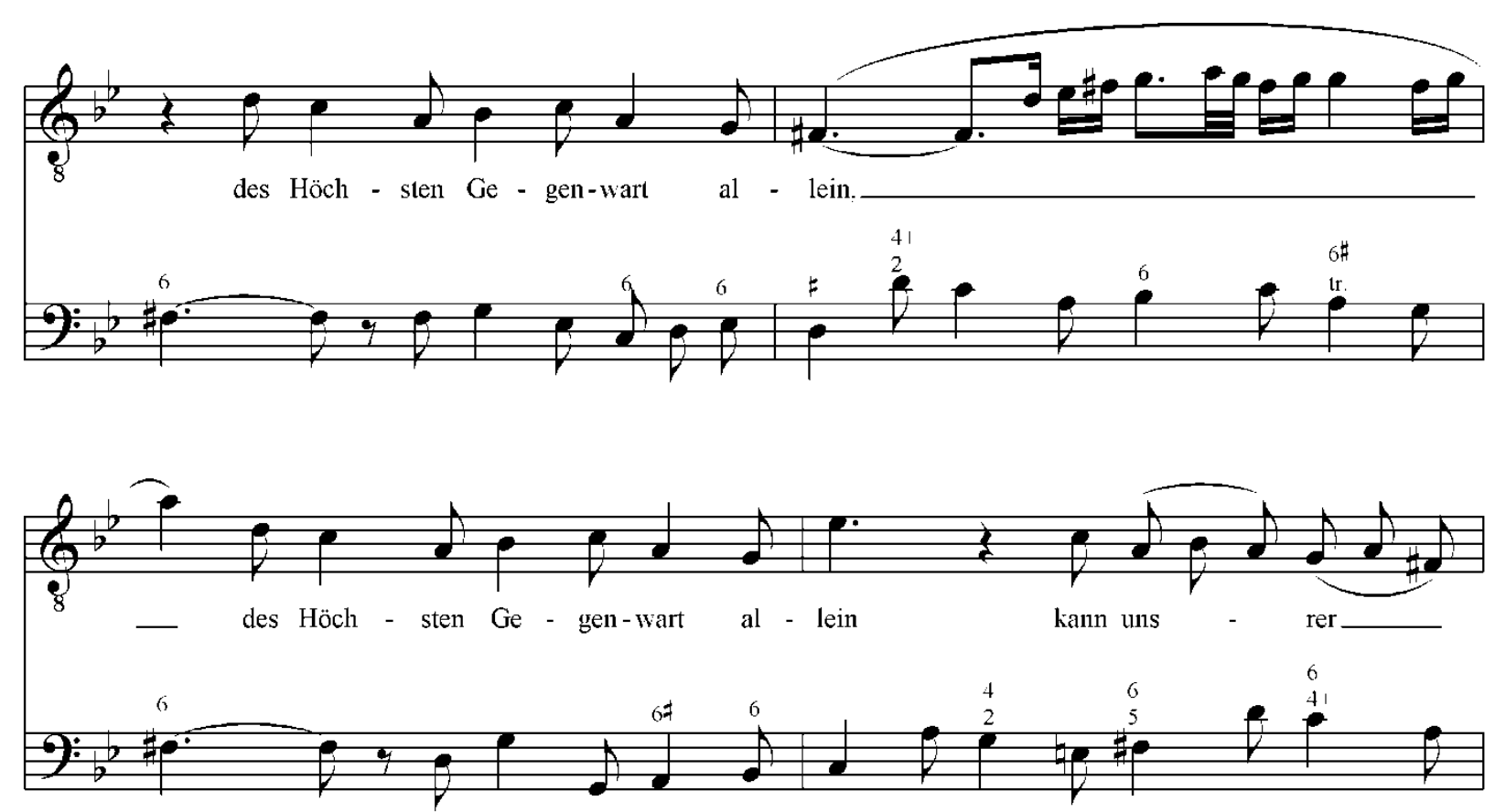

Movement 9, starting in the key of B-flat major and ending in the key of $\mathrm{F}$ major, is a duet recitative (secco) for soprano and bass with basso continuo. Like several duet movements in Bach’s cantatas, this recitative is a dialogue between two points of view.

In his famous sermon for the dedication of the Schloßkirche in Torgau on 5 October 1544, Martin Luther states that in a house of worship "nothing else takes place... than that our dear Lord Himself speaks to us through His Holy Word and that we, in turn, speak to Him in prayer and songs of praise.” The basic form of Christians worship is described here by Luther as a dialogical occurrence. ${ }^{68}$

Following with Luther's views of the dialogical nature of worship, Bach’s duets

frequently feature an interchange between a Divine figure and a human figure. ${ }^{69}$ In this duet, the bass takes the role of the human, or as Melvin Unger suggests, “Doubt.” The soprano takes the

${ }^{67}$ Bach, Höchsterwünschtes Freudenfest, BWV 194, 210-211.

${ }^{68}$ Renate Steiger, "Dialogue Structures in J. S. Bach's Cantatas: The Basic Form of Worship as a Model for Artistic Shaping,” tr. Greta Konradt, BACH: Journal of the Reimenschneider Bach Institute 33, no. 2 (2002): 35.

${ }^{69}$ Ibid., 35-37. 
role of the Divine, or "Confirmation., ${ }^{, 70}$ As each question or concern is raised by the bass voice, his melodic line ascends, just as a spoken question rises in pitch at the end of the sentence. The answer to each query is sung by the soprano, most often with a downward melodic pattern, and a sense of rest at the end, both in the vocal line and the basso continuo part.

As an example, note the shape of each voice's line for the following text (Figure 2.15):

Bass:

Kann wohl ein Mensch zu Gott im Himmel steigen?

Can indeed a mortal to God in heaven ascend?

(Can a mortal indeed ascend to God in heaven?)

Soprano:

Der Glaube kann den Schöpfer zu ihm neigen.

- Faith can the Creator (down) to itself (draw).

(Faith can draw the creator down.) $^{71}$

${ }^{70}$ Unger, Handbook to Bach's Sacred Cantata Texts: An Interlinear Translation with Reference Guide to Biblical Quotations and Allusions, 680.

${ }^{71}$ Ibid. 
Figure 2.15: BWV 194-9, mm. 1-4 $4^{72}$
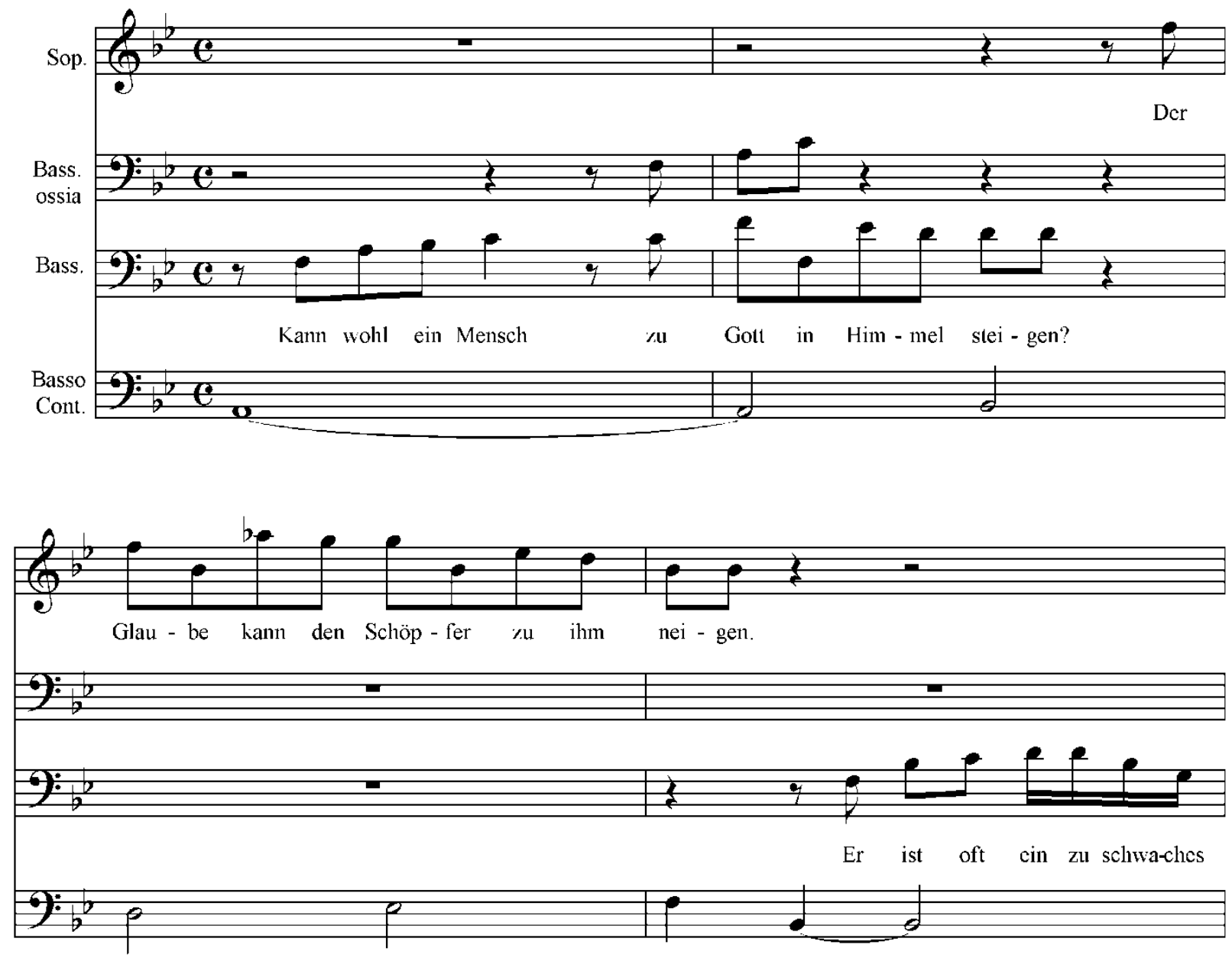

When all the questions are finally answered, the voices sing together, with an andante arioso section, about the joy of mortal life lived in relationship with God. ${ }^{73}$ This section marks the only time an arioso section is used within a recitative in this cantata.

In movement 10, the duet continues between the soprano and bass voices with two oboes and basso continuo as instrumental accompaniment. In F major, this movement is composed in the style of a minuet with gentle pastorale writing for the oboes. ${ }^{74}$ Whittaker attributes length of the movement (324 measures long including the da capo) to the cantata's development from an

${ }^{72}$ Bach, Höchsterwünschtes Freudenfest, BWV 194, 213.

73 Dürr, The Cantatas of J. S. Bach: With Their Librettos in German-English Parallel Text, 720.

74 Ibid. 
instrumental minuet. ${ }^{75}$ In addition to the dance-form association, the next most outstanding musical feature of the movement is not an exceptional melismatic passage, as has been a feature in so many movements up to this point, but a long-held note in one voice, while the other voice continues rhythmic and melodic movement. This type of passage occurs several times in the movement, beginning with the passage in mm. 69-70 (to the first beat), where the bass voice holds through ersehn (has-chosen,) for two full measures and one beat, while the soprano voice continues movement by eighths and sixteenth notes. The voices then exchange held/moving notes in mm. 70-72 (to the first beat), with the soprano taking the held ersehn for two measures and a beat, while the bass voice echoes the same moving notes the soprano voice sang two measures before. The longest held-note passage occurs in mm. 77-81 (to the first eighth note). In this instance, the soprano holds a C5 on ersehn for four measures and one eighth-note, while the oboes and bass voice in alternating duets continue a moving rhythmic pattern. When the soprano finally releases her long-held note, the oboes extend the held-note passage by holding notes (alternating between the two oboe parts) in the next two measures (Figure 2.16).

$O$ wie wohl ist uns geschehn, O how good (it) has for-us (turned-out), (O how we have been blessed.)

Daß sich Gott ein Haus ersehn!

That - God a house has-chosen! ${ }^{76}$

${ }^{75}$ Whittaker, The Cantatas of Johann Sebastian Bach: Sacred and Secular, vol. 1, 269.

${ }^{76}$ Unger, Handbook to Bach's Sacred Cantata Texts: An Interlinear Translation with Reference Guide to Biblical Quotations and Allusions, 682. 
Figure 2.16: BWV 194-10, mm. 76-83 ${ }^{77}$
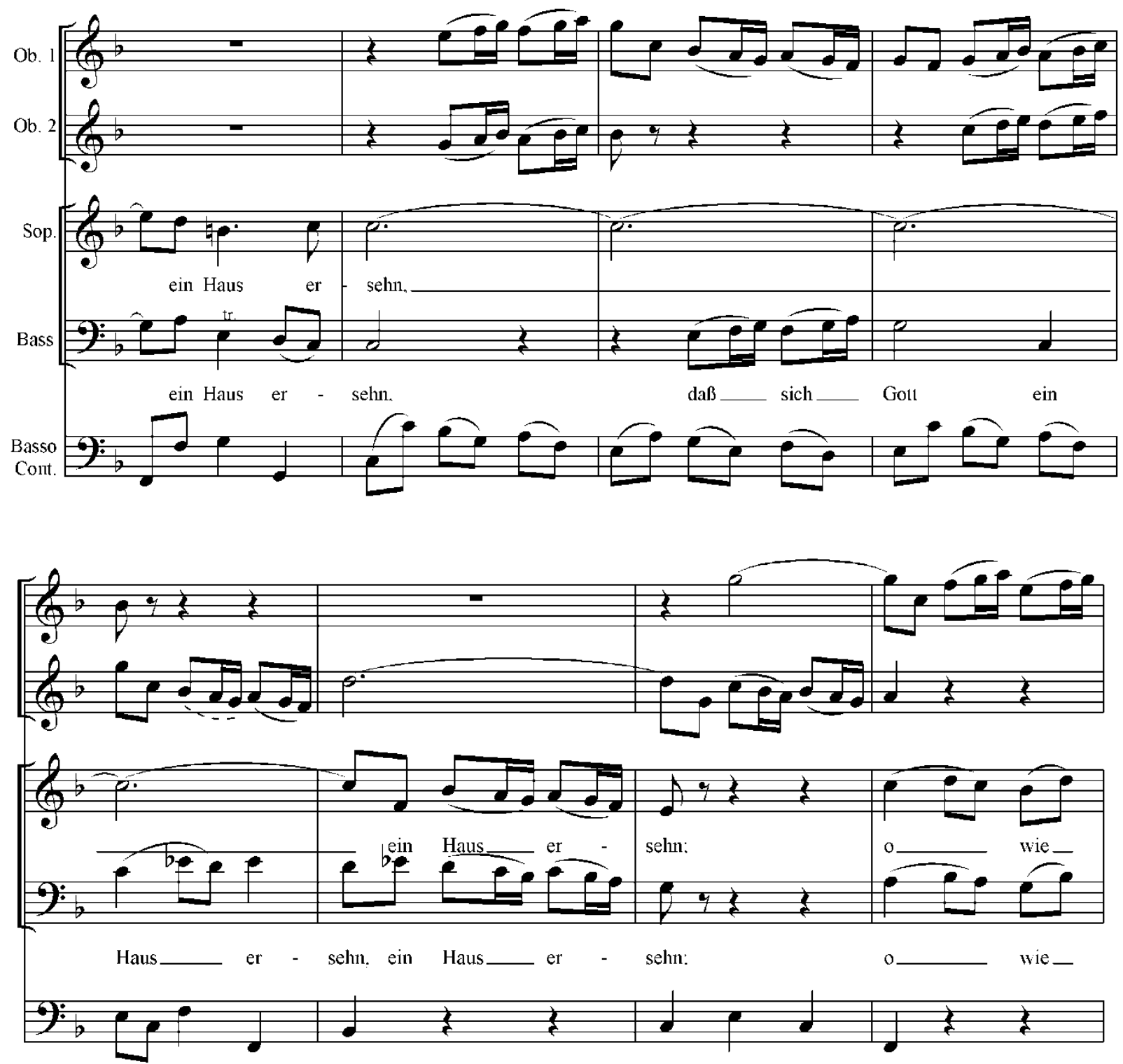

Typical of the second section of da capo movements, there is some variance in the second section of this duet movement. Except for the key change (section two starts in F major, but eventually finishes in D minor), the greatest change lies in the vocal lines: the opening motive is a slight alteration of the opening vocal motive in section one (Figure 2.17) and the rest of the vocal material is new to the movement. The remainder of the musical material in section

\footnotetext{
${ }^{77}$ Bach, Höchsterwünschtes Freudenfest, BWV 194, 221.
} 
two is very similar to section one: the orchestral music is a repetition of section one material and the sentiment of this portion of the composition is the same as it was in the first portion of the movement (expounding on the blessings of being in God's house). ${ }^{78}$

O wie wohl ist uns geschehn,

O how good (it) has for-us (turned-out),

(O how we have been blessed.)

Daß sich Gott ein Haus ersehn!

That - God a house has-chosen!

Schmeckt und sehet doch zugleich,

(O) taste and see indeed together,

(O, both taste and see, )

Gott sei freundlich gegen euch.

God is gracious to you.

(How gracious God is toward you.) ${ }^{79}$

Figure 2.17: BWV 194-10, mm. 31-34 and mm. 145-148 ${ }^{80}$
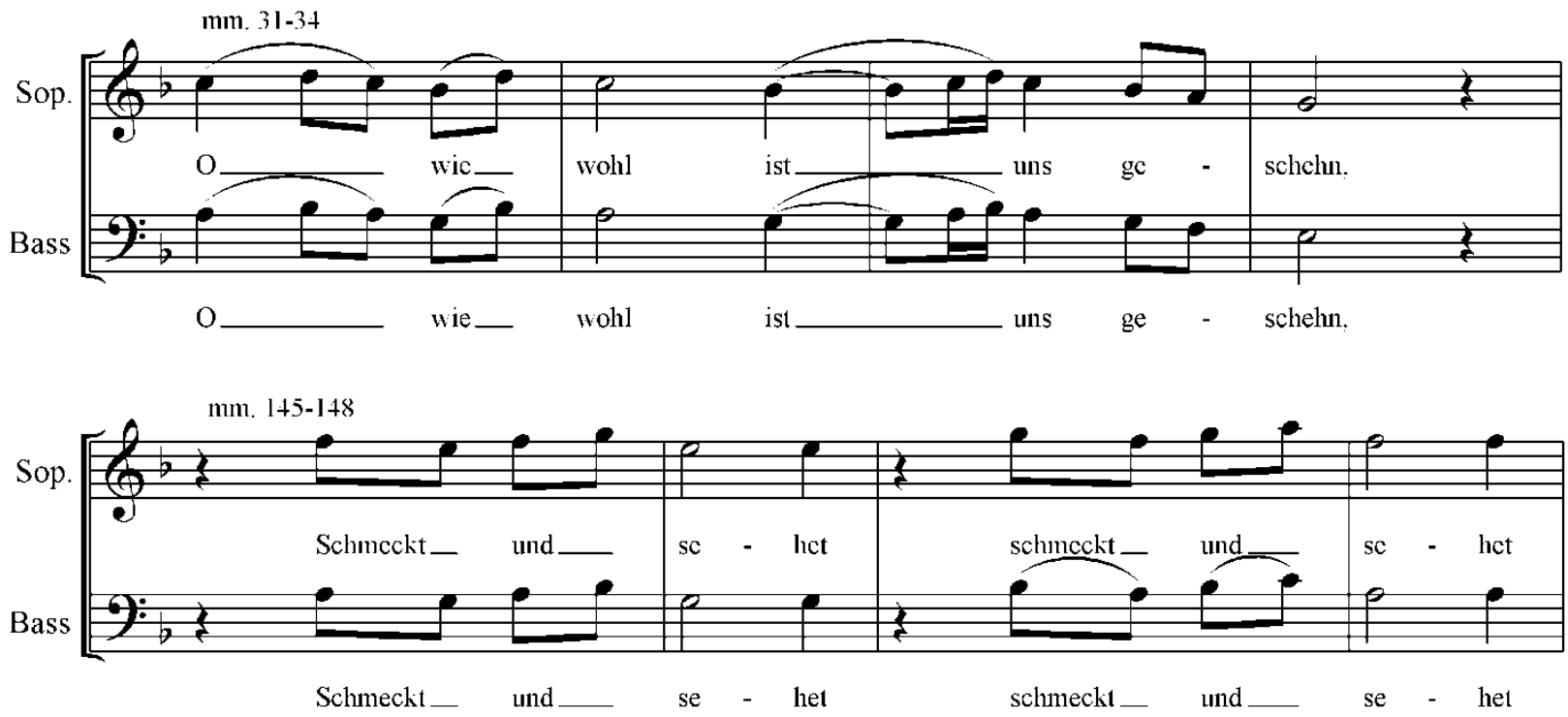

\footnotetext{
${ }^{78}$ Whittaker, The Cantatas of Johann Sebastian Bach: Sacred and Secular, vol. 1, 269.

${ }^{79}$ Unger, Handbook to Bach's Sacred Cantata Texts: An Interlinear Translation with Reference Guide to Biblical Quotations and Allusions, 682.

${ }^{80}$ Bach, Höchsterwünschtes Freudenfest, BWV 194, 217 and 225.
} 
In B-flat major, movement 11 is a recitative for bass with basso continuo. While the musical characteristics of this secco recitative are very similar to other recitatives in this cantata, a significantly unusual aspect of this movement is the way that it fully prepares for the final chorale movement. As far as musical attributes of the recitative, the melodic realization of the text is mostly done in angular, speech-like patterns, with one melismatic figure appropriately set for the word heilige (holy), within the first textual phrase of the movement: Wohlan demnach, du heilige Gemeine, (Come-on, [then], thou holy congregation,). It is important that the composer prepare the audience or congregation for the final chorale movement, because it is thought that the congregations in Bach’s day joined the choir in singing the final chorales (due to their familiarity with these "hymns") and also due to the fact that the final chorale held the core of the whole cantata's message. ${ }^{81}$ Bach accomplished this preparation with the use of the word wohlan (come-on). He set this word once as the first word and note in the recitative, on a low note in the phrase. Then, Bach set wohlan again as the first word in the last phrase of the recitative; however, for this instance of the word, he set it as the highest note in the phrase (an F4), and one of the highest notes the bass sings in this cantata, with a rest directly preceding it (Figure 2.18). One can imagine that hearing the text “Come-on!” sung on a high bass note does a good job of waking up a dosing congregation.

Wohlan, so rüstet euch

Come-on, then (clothe) yourselves mit Geist und Gaben aus, with (the) Spirit and (his) gifts - ,

\footnotetext{
${ }^{81}$ Tanya Kevorkian, “The Reception of the Cantata during Leipzig Church Services, 1700-1750,” 183.
} 
Daß ihm so wohl dein Herz als auch dies Haus gefalle!

That him (both) thine heart as well-as this house please!

(That both thy heart and this house might be pleasing to him!) ${ }^{82}$

Figure 2.18: BWV 194-11, mm. 6-8

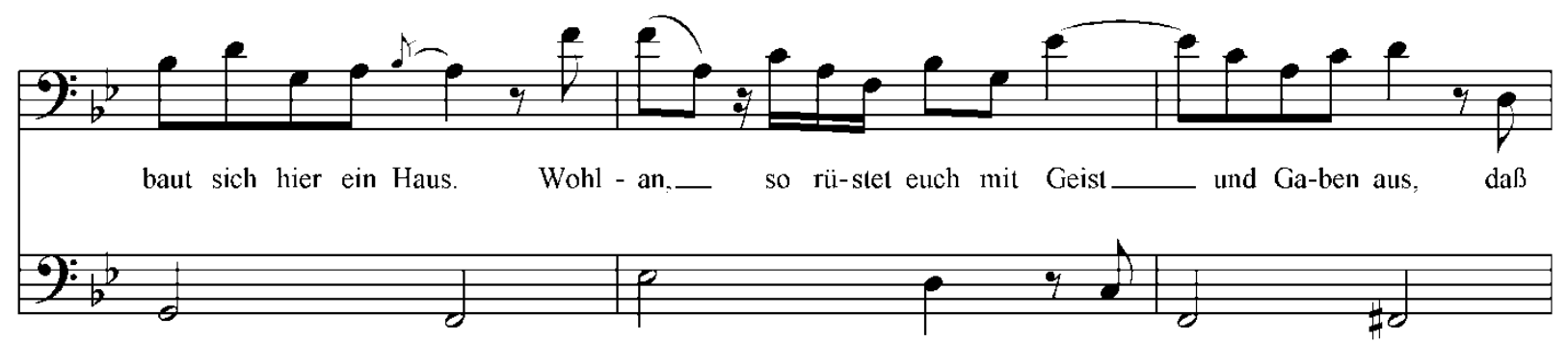

Bach does something very special with the last phrase of text. With the use of the highest notes in this phrase, Bach connects the symbolism of the church house to the heart's "house," seeming to call the congregation to make their hearts pleasing to God, with the same energy that they have put into making the church building a beautiful place (very appropriate for this composition's first hearing - a church/organ dedication service) (Figure 2.19). With the highest notes of the phrase in italics, the phrase would read, "That him (both) thine heart as well-as this house please!" or "That both thy heart and this house might be pleasing to him!"

Figure 2.19: BWV 194-11, mm. 9-11 ${ }^{84}$

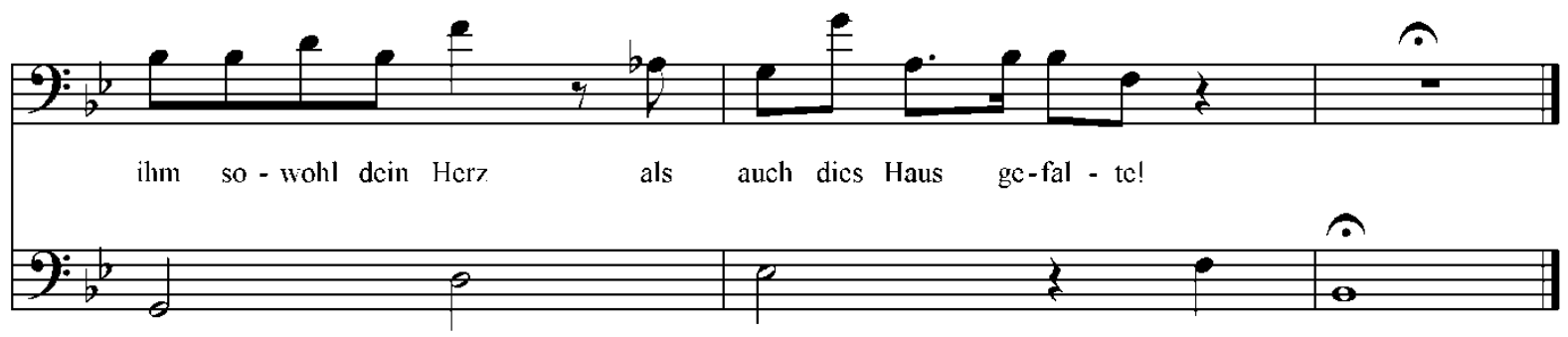

${ }^{82}$ Unger, Handbook to Bach's Sacred Cantata Texts: An Interlinear Translation with Reference Guide to Biblical Quotations and Allusions, 683.

${ }^{83}$ Bach, Höchsterwünschtes Freudenfest, BWV 194, 230.

${ }^{84}$ Ibid. 
Movement 12 brings the cantata to a close with a chorale, scored for four-part chorus with three oboes parts, strings, and basso continuo. In B-flat major, this movement sets the ninth and tenth stanzas of the hymn Wach auf, mein Herz, und singe by Paul Gerhardt. ${ }^{85}$ Like the chorale at the end of Part I, the instruments in this chorale simply double the voice parts, except for the oboe 3. This instrument's part is mostly written independent of the voice parts, due to its compass. ${ }^{86}$ As a connection with the preceding bass recitative, the imagery of the "heart" as the dwelling place for God is again presented in the final verse of the chorale. The position of this theological lesson (of the heart-dwelling) in the final two movements of a cantata written for a church dedication is a profound spiritual teaching for Bach's congregations and a testament to Bach’s own relationship with the Divine.

Verse 1

Sprich Ja zu meinen Taten, Say "Yes" to my endeavors,

Hilf selbst das Beste raten;

Help, thyself, the best to-advise;

(Advise me thyself so I will choose the best part;)

Den Anfang, Mittl und Ende, The beginning, middle, and end,

Ach, Herr, zum besten wende!

Ah Lord, to-the best turn!

(Ah Lord, make them all turn out for the best!)

Verse 2

Mit Segen mich beschütte, With (thy poured-out) blessing me cover, (Pour over me thy blessing,)

Mein Herz sei deine Hütte, (May) my heart be thy shelter, (May my heart be thy abode,)

${ }^{85}$ Humphreys, "Höchsterwünschtes Freudenfest," 222.

${ }^{86}$ Dürr, The Cantatas of J. S. Bach: With Their Librettos in German-English Parallel Text, 716. 
Dein Wort sei meine Speise, (May) thy Word be my food,

Bis ich gen Himmel reise!

Till I to heaven journey! ${ }^{87}$

Unlike the chorale that concludes Part I, this chorale has some chromaticism in the finale measures of the composition that highlight the last phrases of each verse of the cantata and briefly move the key to $G$ minor. In addition to the chromatic element, a sequence in last measures of the bass voice also paints an image of the human journey through life and to heaven, portrayed in both verses of the text. One can envision the sequences of the journey of life in this musical sequence, traveling through similar challenges (and through $\mathrm{G}$ minor), yet finding the way to eventual rest (and back to the "home” key of B-flat major) (Figure 2.20).

${ }^{87}$ Unger, Handbook to Bach's Sacred Cantata Texts: An Interlinear Translation with Reference Guide to Biblical Quotations and Allusions, 683. 
Figure 2.20: BWV 194-12, mm. 12-16 ${ }^{88}$

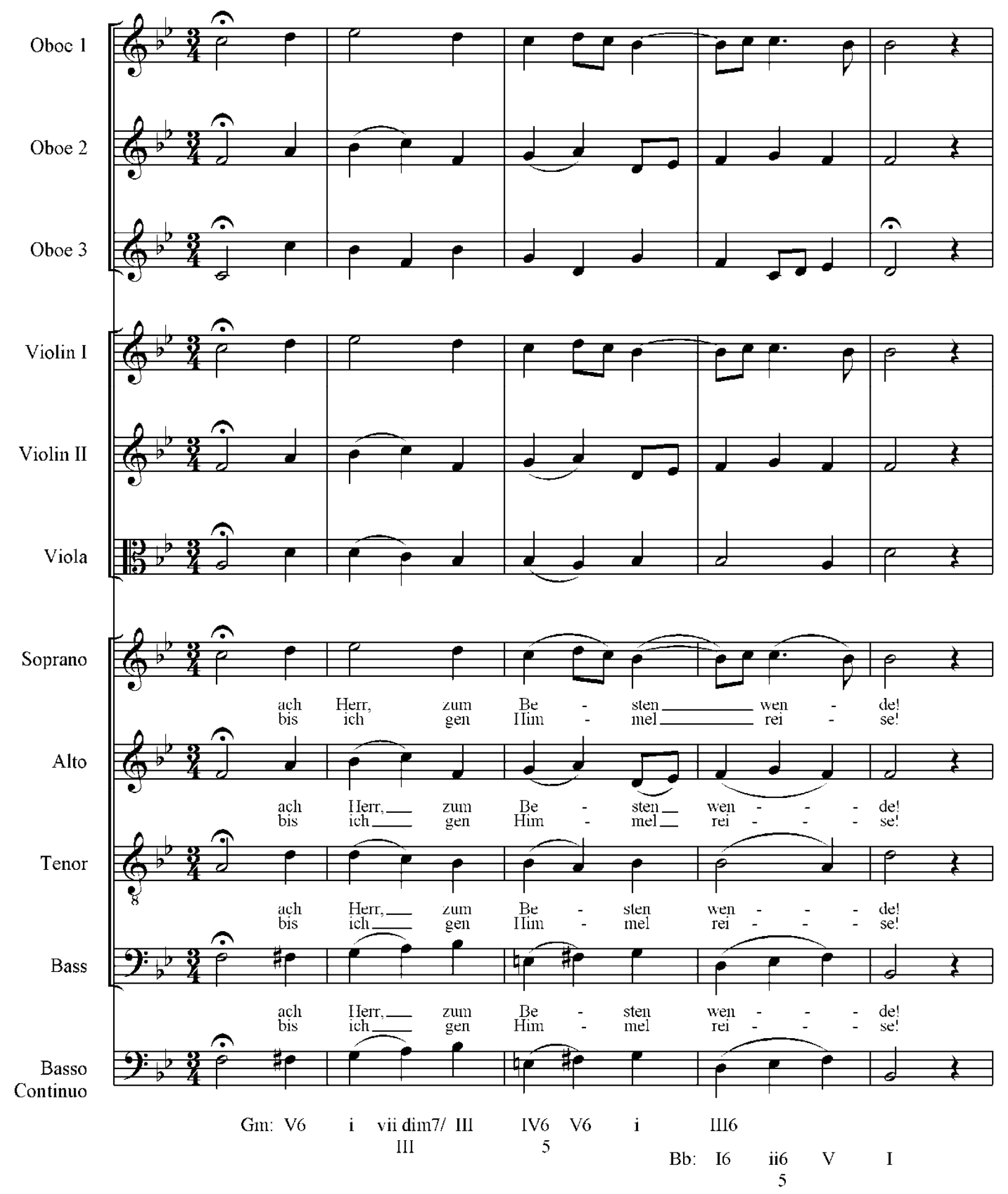

${ }^{88}$ Bach, Höchsterwünschtes Freudenfest, BWV 194, 234. 
Table 2.2: Movement Outline BWV 194

\begin{tabular}{|c|c|c|c|}
\hline Movement & Key/Time & Type & Dance association or Form \\
\hline Part I: 1 & $\begin{array}{l}\text { B-flat major / alle breve time } \\
\text { signature }\end{array}$ & $\begin{array}{l}\text { Chorus for SATB voices with } \\
\text { tutti instruments }\end{array}$ & $\begin{array}{l}\text { French overture; One of only } \\
\text { six extant cantatas that employ } \\
\text { the French overture style }\end{array}$ \\
\hline 2 & $\begin{array}{l}\text { B-flat major / common time } \\
\text { signature }\end{array}$ & $\begin{array}{l}\text { Recitative for bass with basso } \\
\text { continuo }\end{array}$ & Secco recitative \\
\hline 3 & $\begin{array}{l}\text { B-flat major / twelve-eight time } \\
\text { signature }\end{array}$ & $\begin{array}{l}\text { Aria for bass with oboe I, } \\
\text { strings, and basso continuo }\end{array}$ & Pastorale or siciliano \\
\hline 4 & $\begin{array}{l}\text { G minor - E-flat major / } \\
\text { common time signature }\end{array}$ & $\begin{array}{l}\text { Recitative for soprano with } \\
\text { basso continuo }\end{array}$ & Secco recitative \\
\hline 5 & $\begin{array}{l}\text { E-flat major / alla breve time } \\
\text { signature }\end{array}$ & $\begin{array}{l}\text { Aria for soprano with strings } \\
\text { and basso continuo }\end{array}$ & Da capo aria; Gavotte \\
\hline 6 & $\begin{array}{l}\text { B-flat major / common time } \\
\text { signature }\end{array}$ & $\begin{array}{l}\text { Chorale, SATB with tutti } \\
\text { instruments }\end{array}$ & Chorale with two stanzas \\
\hline Part II: 7 & $\begin{array}{l}\text { F major - C minor / common } \\
\text { time signature }\end{array}$ & $\begin{array}{l}\text { Recitative for tenor with basso } \\
\text { continuo }\end{array}$ & Secco recitative \\
\hline 8 & $\begin{array}{l}\text { G minor / common time } \\
\text { signature }\end{array}$ & $\begin{array}{l}\text { Aria for tenor with basso } \\
\text { continuo }\end{array}$ & Da capo aria; Gigue \\
\hline 9 & $\begin{array}{l}\text { B-flat major - F major / } \\
\text { common time signature }\end{array}$ & $\begin{array}{l}\text { Recitative duet for soprano and } \\
\text { bass with basso continuo }\end{array}$ & $\begin{array}{l}\text { Secco recitative ending with a } \\
\text { brief andante arioso section }\end{array}$ \\
\hline 10 & $\begin{array}{l}\text { F major / three-four time } \\
\text { signature }\end{array}$ & $\begin{array}{l}\text { Aria duet for soprano and bass } \\
\text { with oboes I and II and basso } \\
\text { continuo }\end{array}$ & Da capo aria; Minuet \\
\hline 11 & $\begin{array}{l}\text { B-flat major / common time } \\
\text { signature }\end{array}$ & $\begin{array}{l}\text { Recitative for bass with basso } \\
\text { continuo }\end{array}$ & Secco recitative \\
\hline 12 & $\begin{array}{l}\text { B-flat major / three-four time } \\
\text { signature }\end{array}$ & $\begin{array}{l}\text { Chorale, SATB with tutti } \\
\text { instruments }\end{array}$ & Chorale with two stanzas \\
\hline
\end{tabular}




\section{Chapter 3: O heilges Geist- und Wasserbad, BWV 165}

Chapter 3 describes the six-movement $O$ heilges Geist- und Wasserbad (O holy bath of spirit and water), BWV 165. Highlights of this chapter include the history of the cantata's origin from Bach’s work in Weimar; the connection with librettist Solomo Franck, with whom Bach collaborated on almost all of his sacred cantatas from Weimar; and a detailed description of this amazingly diverse work which used only a modest number of musicians.

\section{Scoring}

O heilges Geist- und Wasserbad, BWV 165, is scored for soprano, alto, tenor and bass soloists; a four-part chorus; and an orchestra of two violins, viola, bassoon, and basso continuo. ${ }^{1}$ The movements take the following form:

Mvmt. 1 - Aria: Soprano solo; strings, bassoon, and basso continuo; G major; common time signature

Mvmt. 2 - Recitativo: Bass solo; basso continuo; E minor and A minor; common time signature

Mvmt. 3 - Aria: Alto solo; basso continuo; E minor; twelve-eight time signature

Mvmt. 4 - Recitativo: Bass solo; strings, bassoon, and basso continuo; B minor and G major; common time signature

Mvmt. 5 - Aria: Tenor solo; violins I and II, and basso continuo; G major; common time signature

Mvmt. 6 - Chorale: SATB choir; strings, bassoon, and basso continuo; G major; common time signature

\footnotetext{
${ }^{1}$ Johann Christian, "O heilges Geist- und Wasserbad," In Oxford Composer Companions: J. S. Bach, ed. Malcom Boyd (Oxford: Oxford University Press, 1999), 331; Johann Sebastian Bach, O heilges Geist- und Wasserbad, BWV 165, ed. Alfred Dürr and Robert Freeman, Neue Ausgabe sämtlicher Werke, ser. 1, vol. 15, Kantaten (Kassel, Germany: Bärenreiter, 1967), 3-16.
} 


\section{Performance/Compositional History}

O heilges Geist- und Wasserbad was first performed in Weimar on Trinity Sunday, June 16, 1715, where Bach served as concertmaster of the court cappelle. ${ }^{2}$ The cantata was repeated in Weimar on Trinity Sunday, June 7, 1716, then again in Leipzig on the final Sunday of Jahrgang I, Trinity Sunday, June 4, $1724 .^{3}$ As mentioned previously in this document, the cantata was paired with BWV 194 for the 1724 Leipzig performance. This cantata is similar to other Jahrgang I cantatas (including BWV 194), in that it was a performance of a previouslycomposed work. ${ }^{4}$ Regarding its original performance, it is similar to other Weimar cantatas with its modest vocal/instrumental forces and lack of a grand choral movement: four solo voices are joined by strings, bassoon, and basso continuo (with a four-part chorus that only performs a simple concluding chorale). The bassoon does not play its own independent part; it simply joins the basso continuo at indicated moments. ${ }^{5}$

Table 3.1: Performance History of BWV 165

\begin{tabular}{r|c|c|c}
$\begin{array}{r}\text { Date of } \\
\text { performance }\end{array}$ & June 16,1715 & June 7,1716 & June 4, 1724 \\
\hline $\begin{array}{r}\text { Location of } \\
\text { performance }\end{array}$ & Weimar & Weimar & Leipzig \\
\hline $\begin{array}{r}\text { Purpose of } \\
\text { cantata }\end{array}$ & $\begin{array}{c}\text { Trinity Sunday } \\
\text { cantata }\end{array}$ & $\begin{array}{c}\text { Trinity Sunday } \\
\text { cantata }\end{array}$ & $\begin{array}{c}\text { Trinity Sunday } \\
\text { cantata (paired } \\
\text { with BWV 194) }\end{array}$
\end{tabular}

${ }^{2}$ Christian, "O heilges Geist- und Wasserbad," 331; Wolff, Johann Sebastian Bach: The Learned Musician, 147.

${ }^{3}$ Christian, "O heilges Geist- und Wasserbad," 331; Wolff, Johann Sebastian Bach: The Learned Musician, 273.

${ }^{4}$ Wolff, Johann Sebastian Bach: The Learned Musician, 187.

${ }^{5}$ Christian, "O heilges Geist- und Wasserbad," 331. 


\section{Libretto}

The text for the cantata, by Solomo Franck (1659-1725), was drawn from Evangelisches Andachts-Opffer, Franck's cycle of texts for the church year of $1715 .{ }^{6}$ The libretto for the cantata is closely based on the Gospel reading for Trinity Sunday, John 3:1-15, with a particular focus on Jesus’ words to Nicodemus: “Except a man be born of water and of the Spirit, he cannot enter into the kingdom of God."7

The collaboration between Franck and Bach began in Weimar, 1714; all of Bach’s church cantatas written in Weimar (except for two) use texts written by him. In Wiemar, Franck served as consistorial secretary, librarian, and head of the numismatic collection of the city, beginning in 1701. His position was a governmental post held for generations by individuals in his family. ${ }^{8}$ In addition to his governmental role, he was also a poet, writing sacred texts that combined strophic verses with biblical passages. At 50 years old, Franck was eager to employ new principles in his cantata-text writing: to include da capo arias and recitative structures in his poetic work. It was at this juncture in his career (1714) when Bach joined forces with him to work on sacred cantatas. Bach was so taken with Franck’s work that, even beyond Weimar, in his Leipzig years, he continued to use Franck's texts with some of his cantata projects (BWVs 70, 72, 80, and 168). ${ }^{9}$

The hymn writer for movement 6, Ludwig Helmbold (1532-1598), was a school headmaster, a university professor, the Dean of Philosophical Faculty at the Erfurt University, and the general-superintendent of the church school in Mühlhausen. Considered one of the

\footnotetext{
${ }^{6}$ Dürr, The Cantatas of J. S. Bach: With Their Librettos in German-English Parallel Text, 373.

${ }^{7}$ Christian, "O heilges Geist- und Wasserbad," 331; Konrad Küster, “Franck, Solomo,” In Oxford Composer Companions: J. S. Bach, ed. Malcolm Boyd (Oxford: Oxford University Press, 1999), 176.

${ }^{8}$ Küster, "Franck, Solomo,” 176-177.

${ }^{9}$ Ibid., 177.
} 
principal poets of his day, he was named poet laureate by Emperor Maximilian. Four of his texts were used in Bach's cantatas and vocal works. ${ }^{10}$

Dürr describes the libretto of BWV 165:

The rebirth from the spirit which Jesus discusses with Nicodemus is granted to the Christian in baptism (no. 1). It nullifies the "sinful birth of damned Adam's legacy" and puts Christians into a state of grace (no. 2). Yet the covenant of grace needs to be renewed throughout my whole lifetime (no. 3). For the "old serpent's bruise" -- that is, Adam's Fall -- means that even the pledged baptismal covenant keeps being broken and the Christian constantly requires renewed forgiveness (no. 4). The freely versified text closes with a prayer for the realization that Christ's Death on the Cross has brought us salvation (nos. 4 and 5). The fifth verse of the hymn Nun laßt uns Gott dem Herren by Ludwig Helmbold (1575) then follows as a confirmatory concluding chorale.

The formal structure of the text is clear and visible at a glance. Of the outer movements, no. 1 sets the theme and no. 6 unites what has been expounded and refers back to the opening. In the inner movements, reflection in a recitative is twice followed by prayer in the form of an aria. The first of these sequences, nos. 2-3, deals with baptism as the salvation of the Christian, the second, nos. 4-5, with the consecration of the baptized Christian until death. Several phrases in Franck's text refer directly to the gospel reading: for example, "What is born of the flesh is nothing but flesh" (no. 2; John 3.6) and "Blood-red serpent's image, lifted up on the Cross" (no. 4), which, together with "my serpent of salvation" (no. 5), may be understood with reference to John 3:14-15: "As Moses lifted up the serpent in the wilderness, even so must the Son of Man be lifted up."11

\section{Detail of Each Movement}

With O heilges Geist- und Wasserbad, Bach created a series of movements that are "full of diversity and rich in contrasts," even with the modest forces he used to present this composition. ${ }^{12}$ The first movement of this cantata, in G major, is an aria for soprano, with strings, bassoon, and basso continuo. Though it is a movement featuring the soprano voice, the instruments play an equal role, as is demonstrated immediately in the first section of the

\footnotetext{
${ }^{10}$ Aryeh Oron, “Ludwig Helmbold (Hymn-Writer),” Bach Cantatas Website, 2006, http://www.bachcantatas.com/Lib/Helmbold.htm (accessed September 18, 2010).

${ }^{11}$ Dürr, The Cantatas of J. S. Bach: With Their Librettos in German-English Parallel Text, 373.

12 Ibid.
} 
composition. From mm. 1 to 9 (first beat), the instruments present a full fugal exposition, including a redundant entry in the violin I part. Each instrumental episode also presents a fourpart fugal exposition. The soprano sings every section of this movement as an imitative duet with violin I. From the first measure to the last, this movement is wholly polyphonic. ${ }^{13}$

In terms of textual realizations, Bach expounds with "copious vocal runs” on the words Wasser (water), Lebens (life), and alle (all), bringing these portions of the libretto to the forefront of the listener's attention (Figures 3.1, 3.2, and 3.3). ${ }^{14}$ In the final vocal phrase, a repeated textual passage from the first line of the movement, Bach highlights Geist (Spirit) in addition to Wasser (Figure 3.4). Stephen Daw describes the lines of the soprano part as flowing water, connecting viscerally to the baptismal text. ${ }^{15}$ These key words throughout the movement are identified in bold font, within the following text translation:

O heilges Geist- und Wasserbad, O sacred Spirit- and water-bath,

Das Gottes Reich uns einverleibet Which God's kingdom for-us incorporates (Which puts God's kingdom within us)

Und uns ins Buch des Lebens schreibet!

And us into-the book of life writes! \{And writes our names into the book of life!\}

O Flut, die alle Missetat

O flood, which all iniquity

Durch ihre Wunder kraft ertränket

Through its miraculous-power drowns

(O flood which drowns all iniquity through its miraculous power)

\footnotetext{
${ }^{13}$ Dürr, The Cantatas of J. S. Bach: With Their Librettos in German-English Parallel Text, 373.

${ }^{14}$ Whittaker, The Cantatas of Johann Sebastian Bach: Sacred and Secular, vol. 1, 412.

${ }^{15}$ Daw, The Music of Johann Sebastian Bach, the Choral Works, 60.
} 
Und uns das neue Leben schenket!

And on-us the new life bestows!

(And bestows the new life upon us!)

O heilges Geist- und Wasserbad!

O sacred Spirit- and water-bath! ${ }^{16}$

Figure 3.1: BWV 165-1, mm. 1-2 ${ }^{17}$

primary subject

of the movement

Violin I

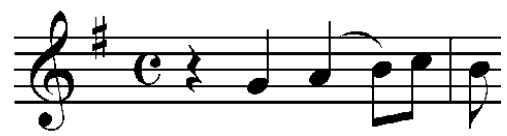

Figure 3.2: BWV 165-1, mm. 9-11 ${ }^{18}$

Note that the first vocal passage of this movement begins with the primary fugal subject of the movement.

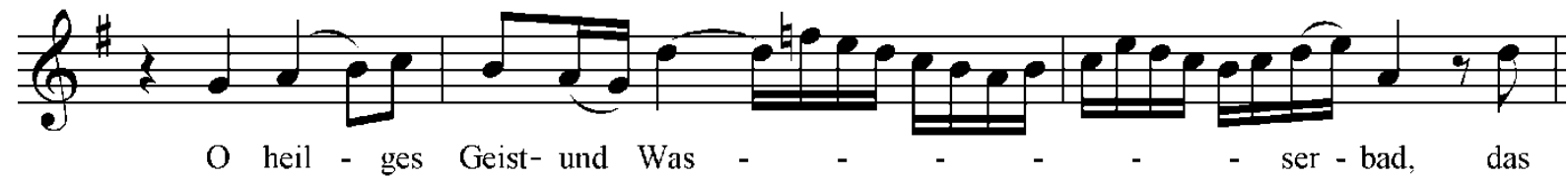

Figure 3.3: BWV 165-1, mm. 18-24 ${ }^{19}$

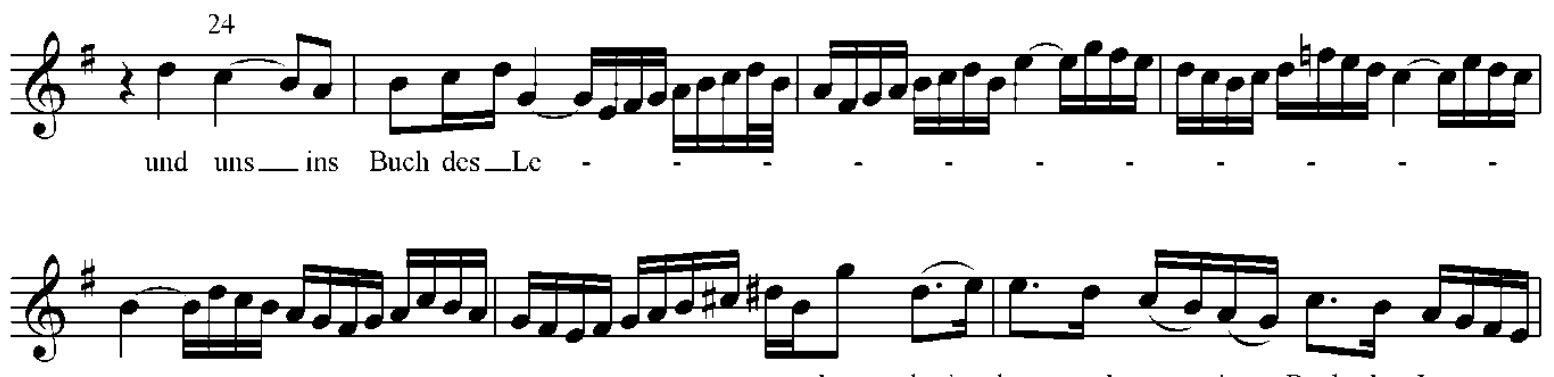

bens schrei - bet, und uns ins_Buch des Le -

${ }^{16}$ Unger, Handbook to Bach's Sacred Cantata Texts: An Interlinear Translation with Reference Guide to Biblical Quotations and Allusions, 569.

${ }^{17}$ Bach, O heilges Geist- und Wasserbad, BWV 165, 3.

${ }^{18}$ Ibid., 3-4.

${ }^{19}$ Ibid., 4-5. 
Figure 3.4: BWV 165-1, mm. 45-49 20

Note that the last vocal passage of this movement begins with the primary fugal subject of the movement.

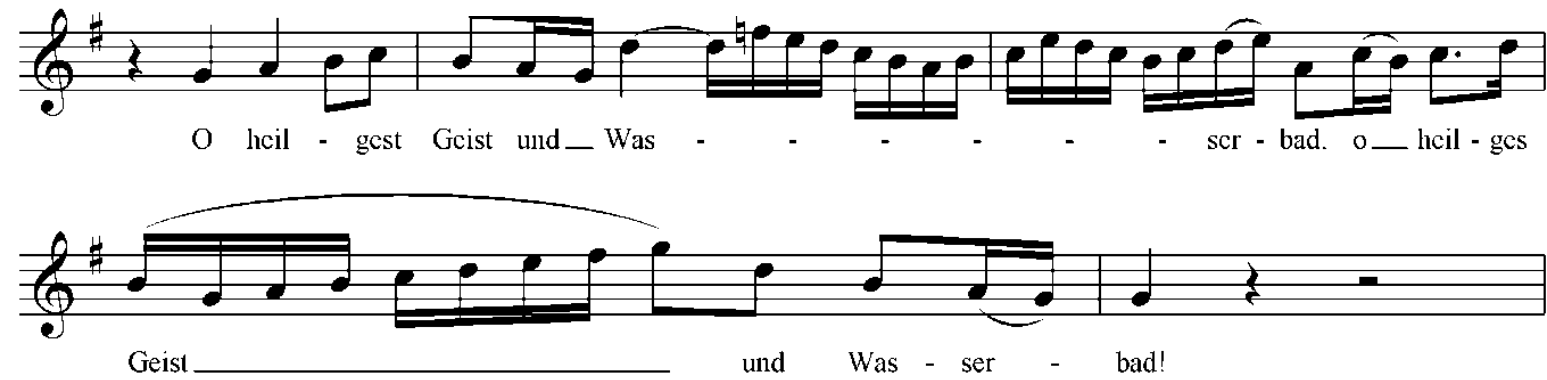

The second movement of the cantata is a secco recitative for bass, with basso continuo, in the keys E minor and A minor. The melodic pattern is mostly speech-like in rhythm, contour, and interval; however, like many of Bach’s early recitatives, sections of the composition almost become ariosos. ${ }^{21}$ When the texts mentions Gottes Zorn (God's wrath), den Tod (death), and das Verderben (perdition) brought on by the sinful nature of humans, Bach composes appropriately anguished lines with chromaticism and numerous tri-tone intervals, for the bass to sing (Figure 3.5).

Die sündige Geburt verdammter Adamserben The sin-begotten birth of-the-cursed heirs-of-Adam (The sinful nature inherited at birth by the cursed heirs of Adam)

Gebieret Gottes Zorn, den Tod und das Verderben.

Gives-birth-to God's wrath, - death, and - perdition.

(Brings God's wrath, death, and perdition upon us.) ${ }^{22}$

${ }^{20}$ Bach, O heilges Geist- und Wasserbad, BWV 165, 7-8.

${ }^{21}$ Dürr, The Cantatas of J. S. Bach: With Their Librettos in German-English Parallel Text, 373-374.

${ }^{22}$ Unger, Handbook to Bach's Sacred Cantata Texts: An Interlinear Translation with Reference Guide to Biblical Quotations and Allusions, 570. 
Figure 3.5: BWV 165-2, mm. 3-6 ${ }^{23}$

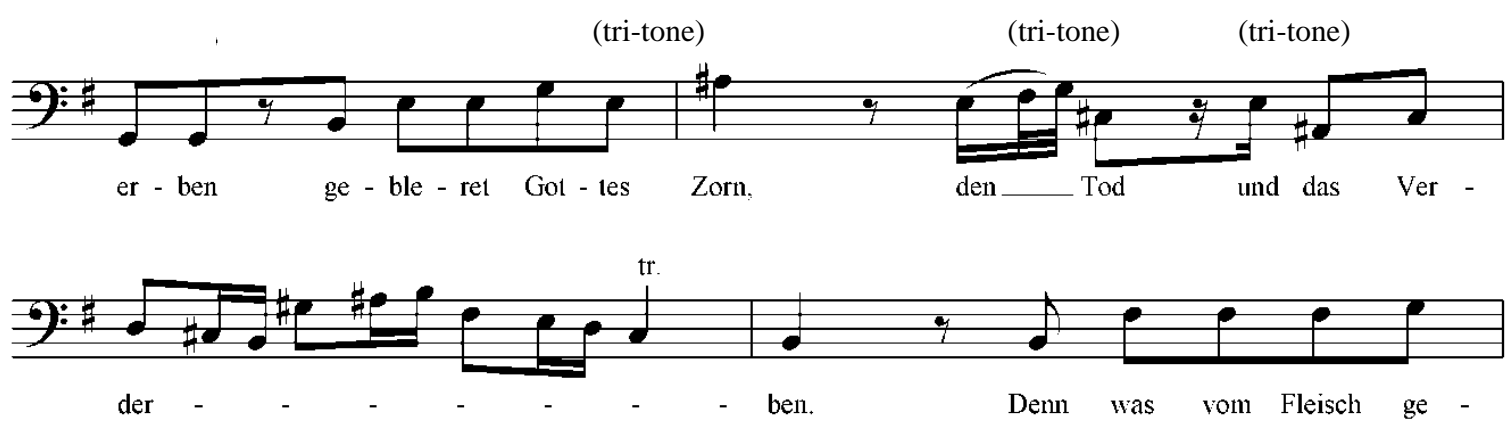

An aria for alto, with basso continuo, is the third movement of the cantata. In E minor, the most prominent feature of this movement is the beautifully shaped line of the basso continuo part, with the first phrase notes repeatedly rising in the interval of a sixth. ${ }^{24}$ This shape is echoed by the alto voice when it enters in the third measure (Figure 3.6). Whittaker aptly refers to this brief aria as a "graceful slow gigue.”25 Perhaps Bach has set this delicate dance to bring out the freue (rejoice) in the fourth line of the text (Figure 3.7).

Jesu, der aus großer Liebe

(O) Jesus, who, out-of great love,

In der Taufe mir verschriebe

In (the-rite-of) baptism to-me has-pledged

(In the rite of baptism pledged to me)

Leben, Heil und Seligkeit,

Life. salvation, and blessedness,

Hilf, daß ich mich dessen freue

Help, that I - over-this might-rejoice

(Help that I might rejoice over this) ${ }^{26}$

${ }^{23}$ Bach, O heilges Geist- und Wasserbad, BWV 165, 9.

${ }^{24}$ Dürr, The Cantatas of J. S. Bach: With Their Librettos in German-English Parallel Text, 374.

${ }^{25}$ Whittaker, The Cantatas of Johann Sebastian Bach: Sacred and Secular, vol. 1, 413.

${ }^{26}$ Unger, Handbook to Bach's Sacred Cantata Texts: An Interlinear Translation with Reference Guide to Biblical Quotations and Allusions, 570-571. 
Figure 3.6: BWV 165-3, mm. 1-3

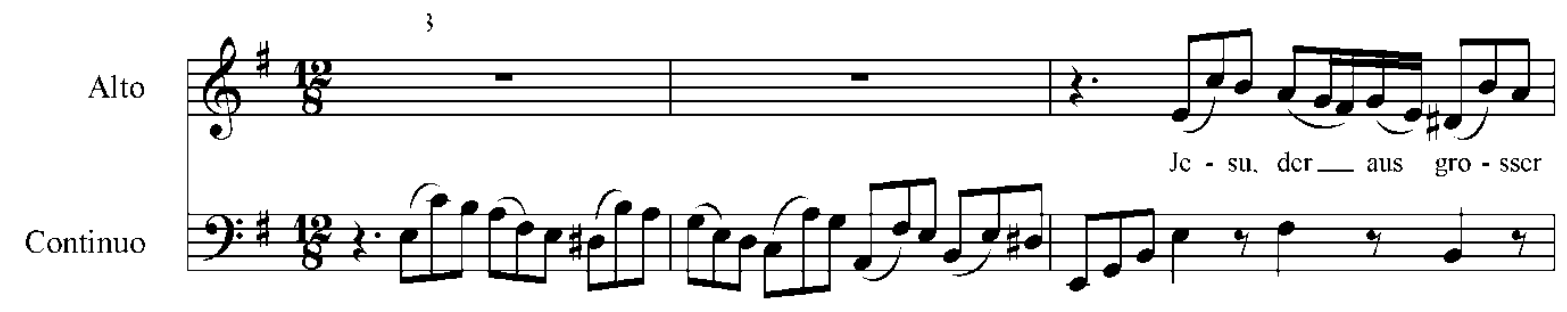

Figure 3.7: BWV 165-3, mm. 17-20 28
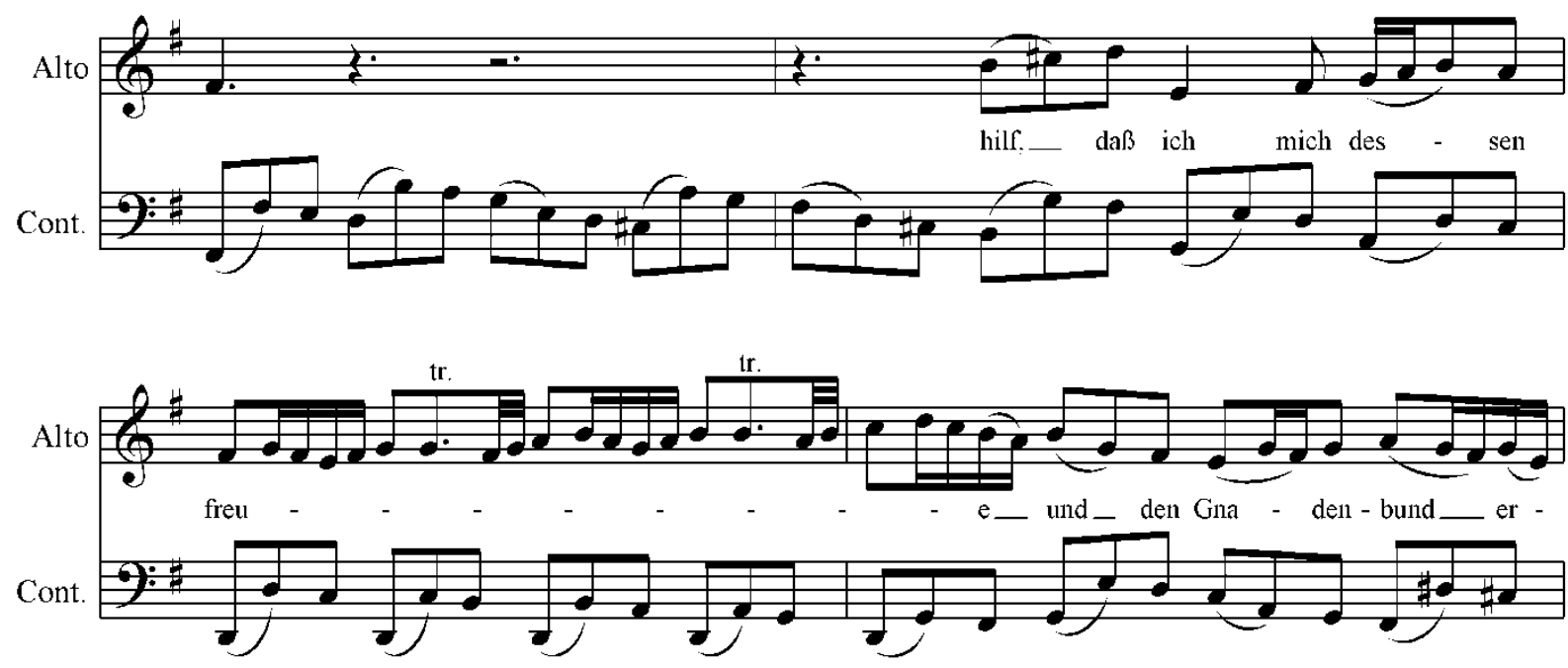

The second recitative for bass, movement 4 , is mentioned as the highlight of this cantata by several Bach scholars. ${ }^{29}$ This recitative is accompanied by the full company of instruments: strings, bassoon, and basso continuo. Unlike the first recitative in this cantata, its melodic pattern repeatedly varies between speech-like sections and arioso passages at an adagio-marked tempo. Not only does the vocal line include several melismas (on hochheiliges Gotteslamm [Most holy Lamb of God], Schlangen [serpent], and gläubig [believing]), but the instruments as well break from their sustained notes to play expressive lines, particularly as part of the realization of the

${ }^{27}$ Bach, O heilges Geist- und Wasserbad, BWV 165, 9.

${ }^{28}$ Ibid., 10.

${ }^{29}$ Daw, The Music of Johann Sebastian Bach, the Choral Works, 60; Christian, "O heilges Geist- und Wasserbad," 331; Whittaker, The Cantatas of Johann Sebastian Bach: Sacred and Secular, vol. 1, 413-414. 
text hochheiliges Gotteslamm..$^{30}$ The importance of this textual phrase is also highlighted by the most extended melisma of the movement given to bass voice, simultaneous with the beginning of the arioso section (at the slow tempo of adagio) (Figure 3.8). For the full translated text of the cantata, please see the Appendix.

Figure 3.8: BWV 165-4, mm. 5-7 $7^{31}$
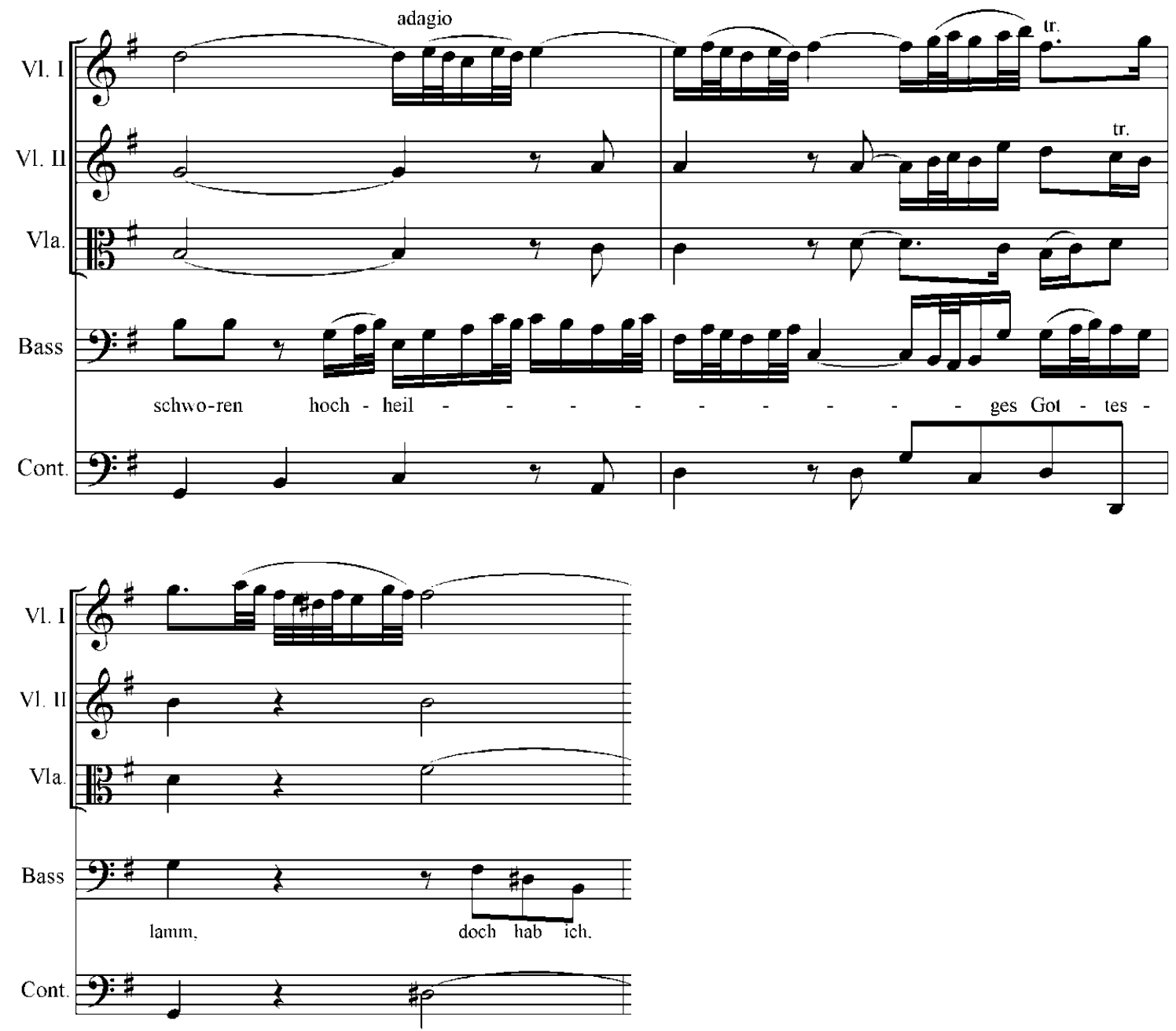

The "writhing of the snake” (der alten Schlangen Stich - "the ancient serpent's sting”) that represents the first sin from the Garden of Eden is beautifully portrayed in mm. 15-16 (Figure 3.9). ${ }^{32}$

${ }^{30}$ Dürr, The Cantatas of J. S. Bach: With Their Librettos in German-English Parallel Text, 374.

${ }^{31}$ Bach, O heilges Geist- und Wasserbad, BWV 165, 11. 
Figure 3.9: BWV 165-4, mm. 15-16 ${ }^{33}$

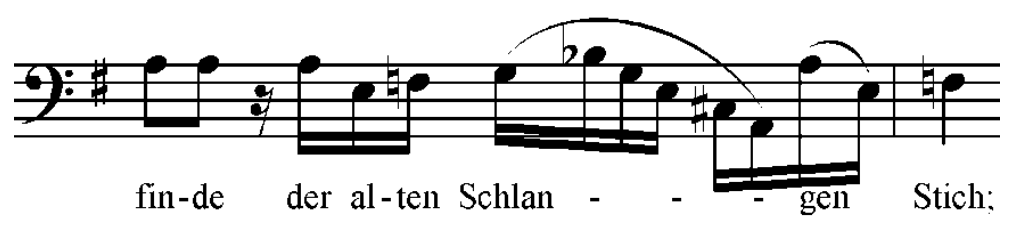

When a phrase about "the cross" is sung in mm. 20-21 (das an dem Kreuz erhöhet, das alle Schmerzen stillt "which on the cross hath-been-raised, which all suffering doth-still”), the Violin I responds with a touching passage in mm. 21-22 (Figure 3.10).

Figure 3.10: BWV 165-4, mm. 20-22

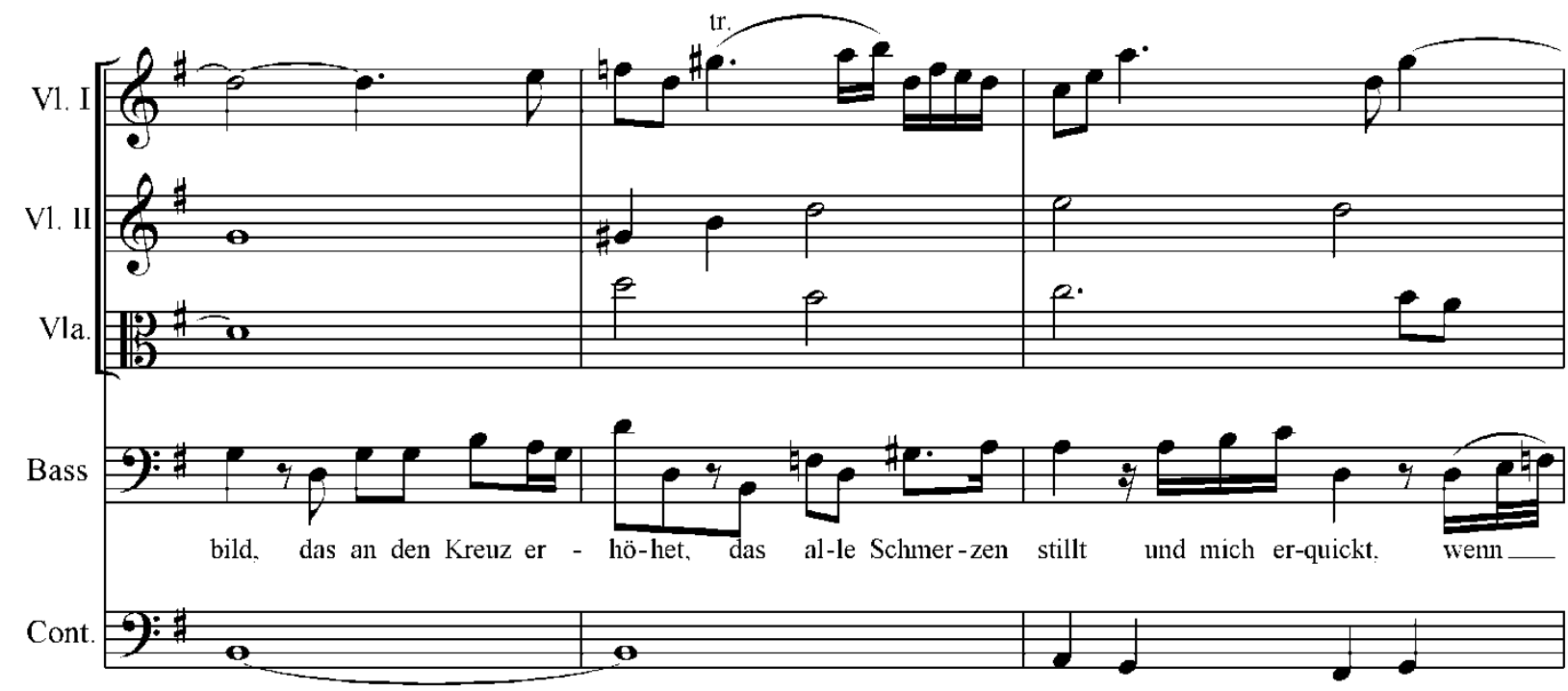

In the last moments of the movement with the text wenn alle Kraft vergehet (when all strength hath-vanished), Bach powerfully portrays the powerlessness experienced by the believer. The vocal line descends to the lowest note in the recitative (G2) and the basso continuo is instructed to only play the bass notes (without chords). After playing a tender passage on the penultimate measure, the upper strings are silent in the final measure, leaving only the single

\footnotetext{
${ }^{32}$ Whittaker, The Cantatas of Johann Sebastian Bach: Sacred and Secular, vol. 1, 414.

${ }^{33}$ Bach, O heilges Geist- und Wasserbad, BWV 165, 12.

${ }^{34}$ Ibid., 12.
} 
basso continuo note, G2. ${ }^{35} \mathrm{All}$ is exhausted and all other parts disappear, except for the lone bass note in the continuo (Figure 3.11).

Figure 3.11: BWV 165-4, mm. 23-24

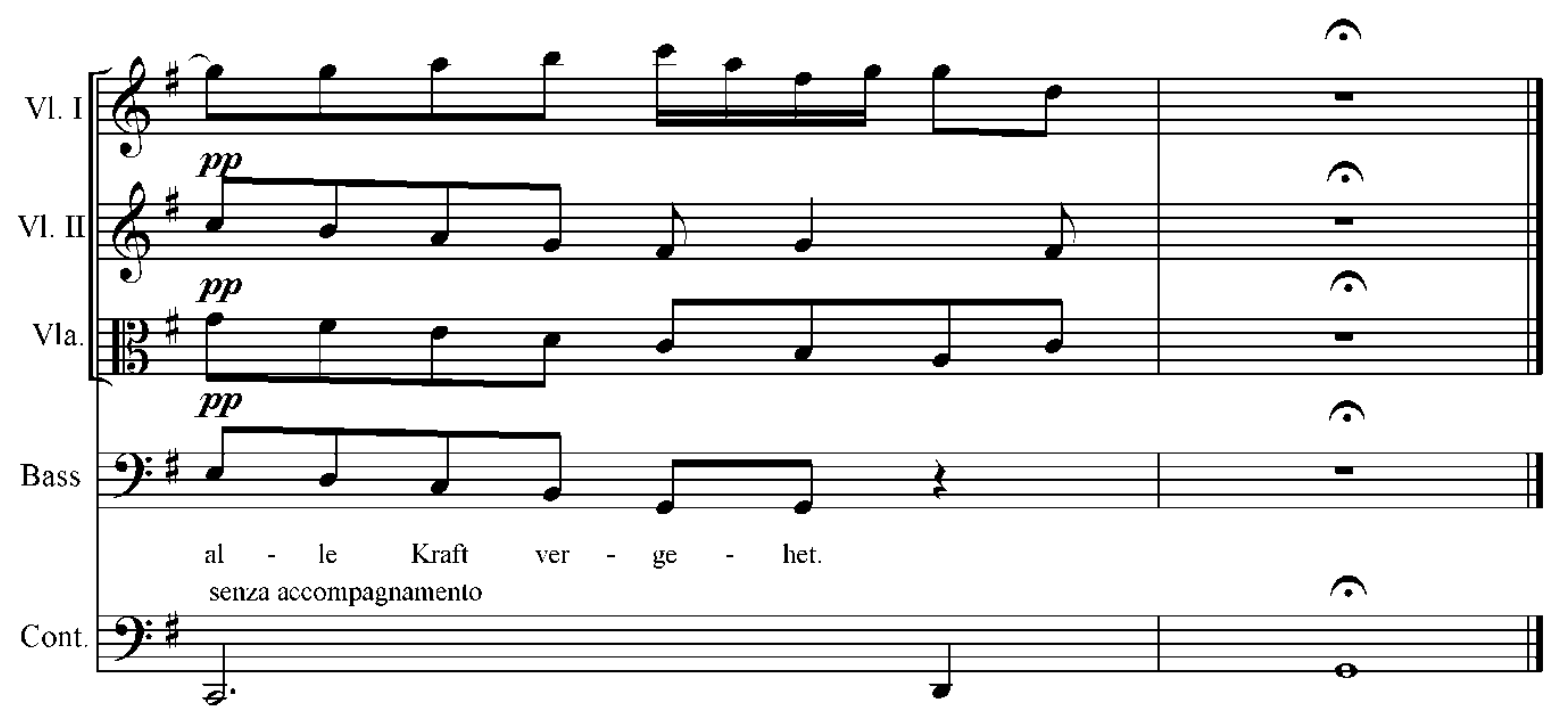

Bach used this same technique of leaving only a single note in the final measure in the alto aria "Esurientes implevit bonis" (Magnificat), at which point "the rich are sent empty away. ${ }^{37}$

Movement 5 is an aria for tenor, joined by the two violin parts in unison, and the basso continuo. The violin part serves as the key figure in this movement. It winds and twists up and down in third- and fourth-duplets, as a "serpent" inspired by the line of the text daß du mein Heilschlänglein seist (that thou my serpent-of-Salvation art) (Figure 3.12). This serpent is not the temptation figure from the Garden of Eden, but is the healing symbol of Christ, based on a

\footnotetext{
${ }^{35}$ Whittaker, The Cantatas of Johann Sebastian Bach: Sacred and Secular, vol. 1, 414.

${ }^{36}$ Bach, O heilges Geist- und Wasserbad, BWV 165, 12.

${ }^{37}$ Christian, "O heilges Geist- und Wasserbad," 332.
} 
passage from Numbers 21:9: "Moses made a bronze serpent, and set it on a pole; and if a serpent bit any man, he would look at the bronze serpent and live.”38

\section{Figure 3.12: BWV 165-5, mm. 1-2 $2^{39}$}

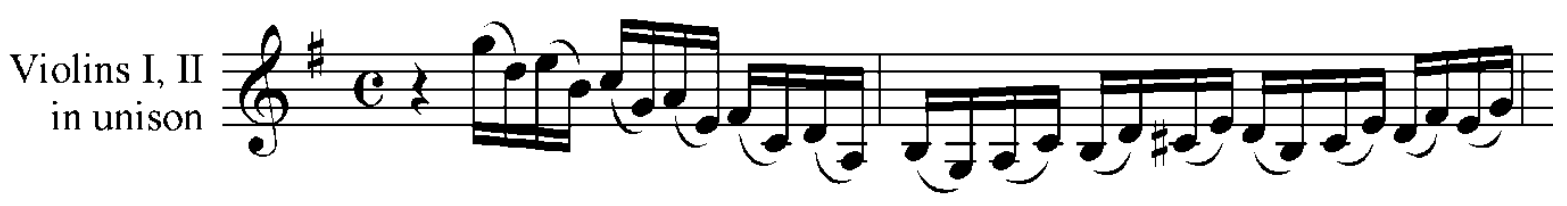

The structure of this movement is as follows: Ritornello A A B B ${ }^{1}$ Ritornello. Once the tenor begins singing, he proceeds with practically no interruption until all of his part in this movement is sung. The instruments begin and end the movement alone. ${ }^{40}$ Whittaker notes a very special moment in the text when "the emotional intensity of the joy of the new birth [through the soul- and spirit-healing of Jesus] is so great that the singer, on the word Leben (heile, Jesu, Seel' und Geist, daß ich Leben finde - “save, Jesu, soul and spirit, that I life [may] find”) must needs leap upwards twice to the extent of a ninth [Figure 3.13].” 41

Figure 3.13: BWV 165-5, mm. 32-35 ${ }^{42}$

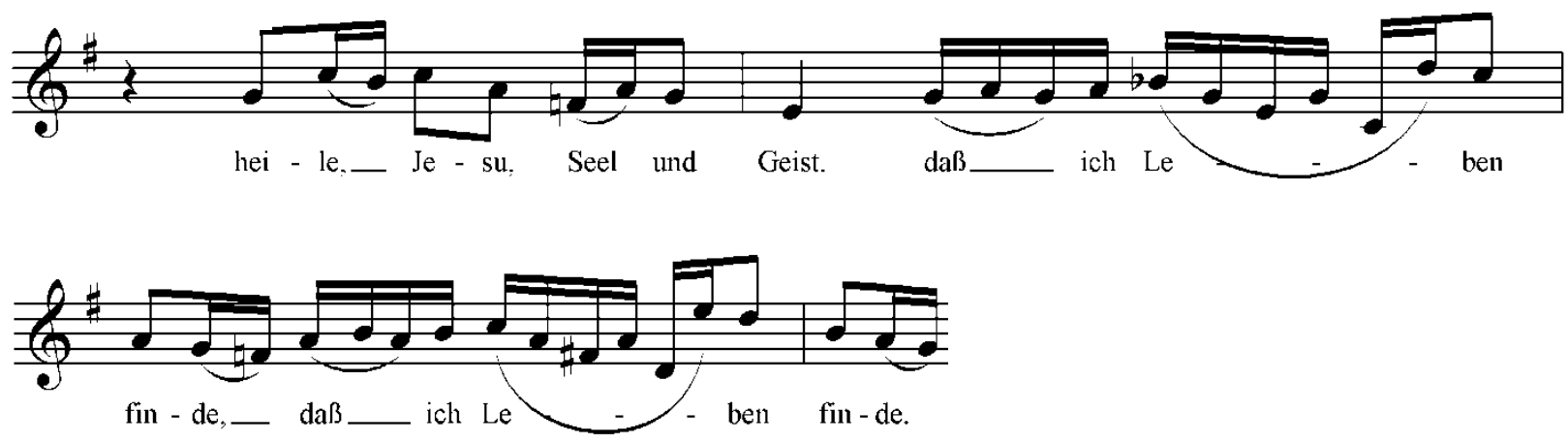

${ }^{38}$ Whittaker, The Cantatas of Johann Sebastian Bach: Sacred and Secular, vol. 1, 414; Unger, Handbook to Bach's Sacred Cantata Texts: An Interlinear Translation with Reference Guide to Biblical Quotations and Allusions, 572.

${ }_{39}$ Bach, O heilges Geist- und Wasserbad, BWV 165, 13.

${ }^{40}$ Dürr, The Cantatas of J. S. Bach: With Their Librettos in German-English Parallel Text, 374.

${ }^{41}$ Whittaker, The Cantatas of Johann Sebastian Bach: Sacred and Secular, vol. 1, 415.

${ }^{42}$ Bach, O heilges Geist- und Wasserbad, BWV 165, 15 
The closing chorale, movement 6, is a setting of stanza five from Ludwig Helmbold's hymn Nun laßt uns gott dem Herren. ${ }^{43}$ With a final indirect connection to the Trinity, it begins by recounting three of the key sacraments of Christian life: Sein Wort, sein Tauf, sein Nachtmall (His Word, His Baptism, His Supper). Continually in the key of G major throughout the chorale, this movement is "very simple, of heavenly peace and contentment;" it has no chromaticism or unusual harmonic changes. ${ }^{44}$ Just as the text describes the three sacraments as a protection from allen Unfall (all calamity), the chorale setting portrays utter peacefulness through its simple harmony and melody.

Sein Wort. sein Tauf, sein Nachtmahl

His Word, his baptism, his supper

Dient wider allen Unfall.

Serves to-counter all calamity;

Der Heilge Geist im Glauben

The Holy Ghost in faith

(Through our faith the Holy Ghost)

Lehrt uns darauf vertrauen.

Teaches us in-this to-trust.

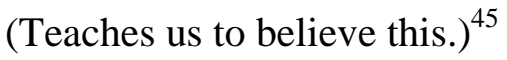

${ }^{43}$ Dürr, The Cantatas of J. S. Bach: With Their Librettos in German-English Parallel Text, 373.

${ }^{44}$ Whittaker, The Cantatas of Johann Sebastian Bach: Sacred and Secular, vol. 1, 415.

${ }^{45}$ Unger, Handbook to Bach's Sacred Cantata Texts: An Interlinear Translation with Reference Guide to Biblical Quotations and Allusions, 573. 
Table 3.2: Movement Outline BWV 165

\begin{tabular}{|c|c|c|c|}
\hline Movement & Key/Time & Type & Special Notes \\
\hline 1 & $\begin{array}{l}\text { G major / common time } \\
\text { signature }\end{array}$ & $\begin{array}{l}\text { Aria for Soprano with tutti } \\
\text { instruments }\end{array}$ & $\begin{array}{l}\text { Wholly polyphonic; each } \\
\text { instrumental episode is a full } \\
\text { fugal exposition. }\end{array}$ \\
\hline 2 & $\begin{array}{l}\text { E minor - A minor / common } \\
\text { time signature }\end{array}$ & $\begin{array}{l}\text { Recitative for bass with basso } \\
\text { continuo }\end{array}$ & Secco recitative \\
\hline 3 & $\begin{array}{l}\text { E minor / twelve-eight time } \\
\text { signature }\end{array}$ & $\begin{array}{l}\text { Aria for alto with basso } \\
\text { continuo }\end{array}$ & "Graceful slow gigue”46 \\
\hline 4 & $\begin{array}{l}\text { B minor - G major / common } \\
\text { time signature }\end{array}$ & $\begin{array}{l}\text { Recitative for bass with tutti } \\
\text { instruments }\end{array}$ & $\begin{array}{l}\text { Accompagnato recitative; } \\
\text { continually varies between } \\
\text { speech-like sections and arioso } \\
\text { passages; very expressive } \\
\text { instrumental writing }\end{array}$ \\
\hline 5 & $\begin{array}{l}\text { G major / common time } \\
\text { signature }\end{array}$ & $\begin{array}{l}\text { Aria for tenor with Violins 1/II } \\
\text { (in unison) and basso continuo }\end{array}$ & $\begin{array}{l}\text { Unison violins have a serpent } \\
\text { motive throughout }\end{array}$ \\
\hline 6 & $\begin{array}{l}\text { G major / common time } \\
\text { signature }\end{array}$ & $\begin{array}{l}\text { Chorale, SATB with tutti } \\
\text { instruments }\end{array}$ & $\begin{array}{l}\text { Simple, peaceful chorale } \\
\text { setting }\end{array}$ \\
\hline
\end{tabular}

\footnotetext{
${ }^{46}$ Whittaker, The Cantatas of Johann Sebastian Bach: Sacred and Secular, vol. 1, 413
} 


\section{Chapter 4: Es ist ein trotzig un verzagt Ding, BWV 176}

Chapter 4 describes the six-movement Es ist ein trotzig un verzagt Ding (The heart is deceitful above all things), BWV 176. Highlights of this chapter include an examination of the librettist for this cantata, Christiane Mariane von Ziegler, with whom Bach collaborated on the final nine cantatas of Jahrgang II; and an observation of the ways that Bach used the forms and the orchestration/voicing of each part of this composition to bring forward his intended message for each movement and for the cantata as a whole.

\section{Scoring}

Es ist ein trotzig un verzagt Ding, BWV 176, is scored for soprano, alto, and bass soloists; a four-part chorus; and an orchestra of two oboes, oboe da caccia, two violins, viola, and basso continuo. ${ }^{1}$ The movements take the following form:

Mvmt. 1 - Chorus: SATB choir; oboes I and II, oboe da caccia, strings, and basso continuo; $\mathrm{C}$ minor; common time signature

Mvmt. 2 - Recitativo: Alto solo; basso continuo; G minor; common time signature Mvmt. 3 - Aria: Soprano solo; strings and basso continuo; B-flat major; alla breve time signature

Mvmt. 4 - Recitativo: Bass solo; basso continuo; F major and G minor; common time signature and three-four time signature

Mvmt. 5 - Aria: Alto solo; oboes I and II, oboe da caccia, and basso continuo; E-flat major; three-eight time signature

Mvmt. 6 - Choral: SATB choir; oboes I and II, oboe da caccia, strings, and basso continuo; F minor and C minor; common time signature

\footnotetext{
${ }^{1}$ David Schulenberg, "Es ist ein trotzig un verzagt Ding," In Oxford Composer Companions: J. S. Bach, edited by Malcom Boyd (Oxford: Oxford University Press, 1999), 164; Johann Sebastian Bach, Es ist ein troztig und verzagt Ding, BWV 176, ed. Alfred Dürr and Robert Freeman, Neue Ausgabe sämtlicher Werke, ser. 1, vol. 15, Kantaten (Kassel, Germany: Bärenreiter, 1967),18-36.
} 


\section{Performance/Compositional History}

BWV 176 was first performed in Leipzig on Trinity Sunday, May 27, 1725, the last Sunday of Jahrgang II. ${ }^{2}$ Like many of the Leipzig cantatas, Bach uses a full complement of instruments in this composition. The typical orchestration that Bach used in Leipzig was a full four-part string quartet, usually with a wind ensemble of three trumpets and timpani, or two oboes and recorders, plus basso continuo. ${ }^{3}$ For the ensemble in this cantata, Bach used an oboe group in addition to the strings, along with the curved tenor-ranged oboe, the oboe da caccia. The oboe da caccia was a favored instrument of Bach’s, employed in over twenty of his cantatas. $^{4}$

In Jahrgang I, Bach drew upon previously-composed cantatas to fill out the roster of the annual cycle, in addition to some new compositions written for Leipzig. ${ }^{5}$ For Jahrgang II, beginning on the first Sunday after Trinity, June 11, 1724, Bach set out to compose a new cantata for each non-Lenten Sunday of the liturgical year, each using the same librettist, and each based on a single hymn-text for all movements in the cantata. Even though the librettist with whom he began working on this cycle is unknown, it is clear that something happened to the librettist in the middle of the year, because the chorale cantatas ceased after the feast of the Annunciation, March 25, 1725. Scholars theorize that the librettist for the first part of Jahrgang II was Andres Stübel, “conrector emeritus of the St. Thomas School, a man of solid theological background (if somewhat nonconformist views) and ample poetic experience.”6 Historians have established this theory because of Stübel's obvious relationship with Bach, through their work with St. Thomas

\footnotetext{
${ }^{2}$ Wolff, Johann Sebastian Bach: The Learned Musician, 278.

${ }^{3}$ Ibid., 273.

${ }^{4}$ Reine Dahlqvist, “Taille, Oboe da Caccia and Corno Inglese,” The Galpin Society Journal 26 (May 1973), 58-60.

${ }^{5}$ Wolff, Johann Sebastian Bach: The Learned Musician, 269.

${ }^{6}$ Ibid., 275-278.
} 
School, and the occasion of Stübel's death on January 27, 1725. Stübel's death date would have coincided with the cessation of texts by the first librettist of Jahrgang II. $^{7}$

Cantatas with varying origins and structures were used in the cycle of cantatas from Easter Sunday, April 1, 1725, through Misericordias Domini Sunday, April 15, 1725; however, beginning with Jubilate Sunday, April 22, 1725, and continuing through Trinity Sunday, May 27, 1725, Bach chose a new librettist for his cantatas. For this period of nine cantatas, he collaborated with "the young Leipzig poet Christiane Mariane von Ziegler, daughter of the former burgomaster Franz Conrad Romanus.”8

\section{Libretto}

Christiane Mariane von Ziegler (1695-1760) was born into a wealthy and influential family in Leipzig. Her father was installed as one of Leipzig's majors in 1701; however he was "arrested without stated charges in 1705 and imprisoned without trial until his death in 1746."

The reason for his imprisonment is not known. ${ }^{9}$ By the time that Bach began his collaboration with Zeigler, she had been widowed twice and had also lost her children. Around 1722, while Ziegler was again living in her parent's home in Leipzig, she began to become greatly involved in the arts. "She wrote poetry and played the clavier, lute, and transverse flute." ${ }^{\prime 10}$ She published her own poetry in 1728 and 1729, and in 1728, she was named poet laureate by the Wittenberg philosophy faculty. She married once more in 1741 . Even though she was virtually unknown as a poet when she began her work with Bach, Ziegler eventually became “one of Germany’s

\footnotetext{
${ }^{7}$ Wolff, Johann Sebastian Bach: The Learned Musician, 278.

${ }^{8}$ Ibid., 277-279.

${ }^{9}$ Mark A Peters, A Woman's Voice in Baroque Music: Mariane Von Ziegler and J. S. Bach (Burlington, VT: Ashgate, 2008), 2.

${ }^{10}$ Dürr, The Cantatas of J. S. Bach: With Their Librettos in German-English Parallel Text, 33.
} 
preeminent poets and one of its most outspoken advocates for women's rights.” ${ }^{11}$ As an example of one of Ziegler's writings that spoke out for women, her Moralische und vermischte SendSchreiben (1731) argued that women "possessed the same patience and diligence on which men prided themselves, and [that] if a woman studied from her youth she could achieve the same levels of learning as a man."12

The choice of Zeigler as his librettist for the nine works was remarkable, in this era when society prohibited “women’s public self-expression, and... women’s speaking in the church.”13 At the time of their collaboration, Ziegler had no published writings as a poet, she was ten years younger than Bach (Ziegler was 30), she was not connected to the church in any official way, and she had "no formal theological training."14 The exact details of their work together are not known; however, Hans-Joachim Schulze theorizes that they were "introduced by a mutual friend, Maria Elisabeth Taubert. The first of the nine cantatas [in which their efforts were joined] was performed just a few days after the birth of Bach’s son Christian Gottlieb, for whom Taubert served as godmother." 15 What is known about the librettos for BWV 176 and the other eight cantatas (BWV 103, 108, 87, 128, 183, 74, 68, and 175) is that Bach modified every text. "Evidently, he was intent on tightening the substance of the text, and in doing so he shows a striking tendency to lists of words without conjunctions, for example Teufel, Tod (devil, death) in place of Sünd und Tod (sin and death)."16 Paul Gerhardt was the hymn writer for movement 6. Please see in the Libretto section of Chapter 2 for more information about Gerhardt.

\footnotetext{
${ }^{11}$ Peters, A Woman's Voice in Baroque Music: Mariane Von Ziegler and J. S. Bach, 3-4.

12 Ibid., 11.

${ }^{13}$ Ibid., 4.

${ }^{14}$ Ibid., 2.

${ }^{15}$ Ibid., 3.

${ }^{16}$ Dürr, The Cantatas of J. S. Bach: With Their Librettos in German-English Parallel Text, 33.
} 
The libretto for BWV 176 was closely based on the conversation between Jesus and

Nicodemus, a "ruler of the Jews," found in the Gospel reading for Trinity Sunday, John 3:1-15.

Ziegler seems particularly interested in the detail that Nicodemus would only meet Jesus at night. ${ }^{17}$

Here she finds a general human characteristic: "The heart is a perverse and desperate thing; who can fathom it?," says the prophet Jeremiah (17:9), and the poet prefaces her text with these words -- slightly modified -- as a motto. Unlike the days of Joshua, when the sun stood still at Gibeon till the hoards of the Amorites had been vanquished (Joshua 10:12), Nicodemus longs for night to come (no. 2). The following aria first takes up the same ideas and then proceeds with the words of Nicodemus: no one could do the signs that Jesus does unless God were with him. The second recitative-aria pair gives an indication of the comfort that the fearful Christian derives from faith in Jesus. Bach himself lends still greater weight to this reflection by adding to the recitative words of the poet a paraphrase of John 3:16: "For all who but believe in You shall not be lost." With praise and thanks for this promise, the aria leads to the concluding chorale, the eighth verse of the hymn Was alle Weisheit in der Welt by Paul Gerhardt (1653). ${ }^{18}$

\section{Detail of Each Movement}

Typical of the Leipzig cantatas, BWV 176 begins with a grand choral movement with full orchestration. ${ }^{19}$ In C minor, this movement "opens with a defiant, indignant presentation,... a terse, four-part choral fugue set against a string fanfare reminiscent of Brandenburg No. 5.”20 This description is only fitting for the first portion of the fugal subject. After the peak of the line is reached with an upwards-sweeping melisma on trotzig (obstinate) the subject "melts and sighs" as verzagt (disheartening) and the remainder of the textual phrase is sung. "This ascending and descending contour persists throughout the fugue, ...without ritornellos, the voices doubled

\footnotetext{
${ }^{17}$ Dürr, The Cantatas of J. S. Bach: With Their Librettos in German-English Parallel Text, 376.

${ }^{18}$ Ibid.

${ }^{19}$ Wolff, Johann Sebastian Bach: The Learned Musician, 273.

${ }^{20}$ Gardiner, "Bach Cantata Series: Cantatas for Trinity Sunday."
} 
by the three oboes while the strings alternate between the vigorous Brandenburg 5 motif and plaintive, sustained counterpoint [Figure 4.1].”21

Es ist ein trotzig und verzagt Ding

It is an obstinate and disheartening thing

um aller Menschen Herze. about all human hearts. (about the human heart.) $^{22}$

Figure 4.1: BWV 176-1, mm. 1-4 ${ }^{23}$

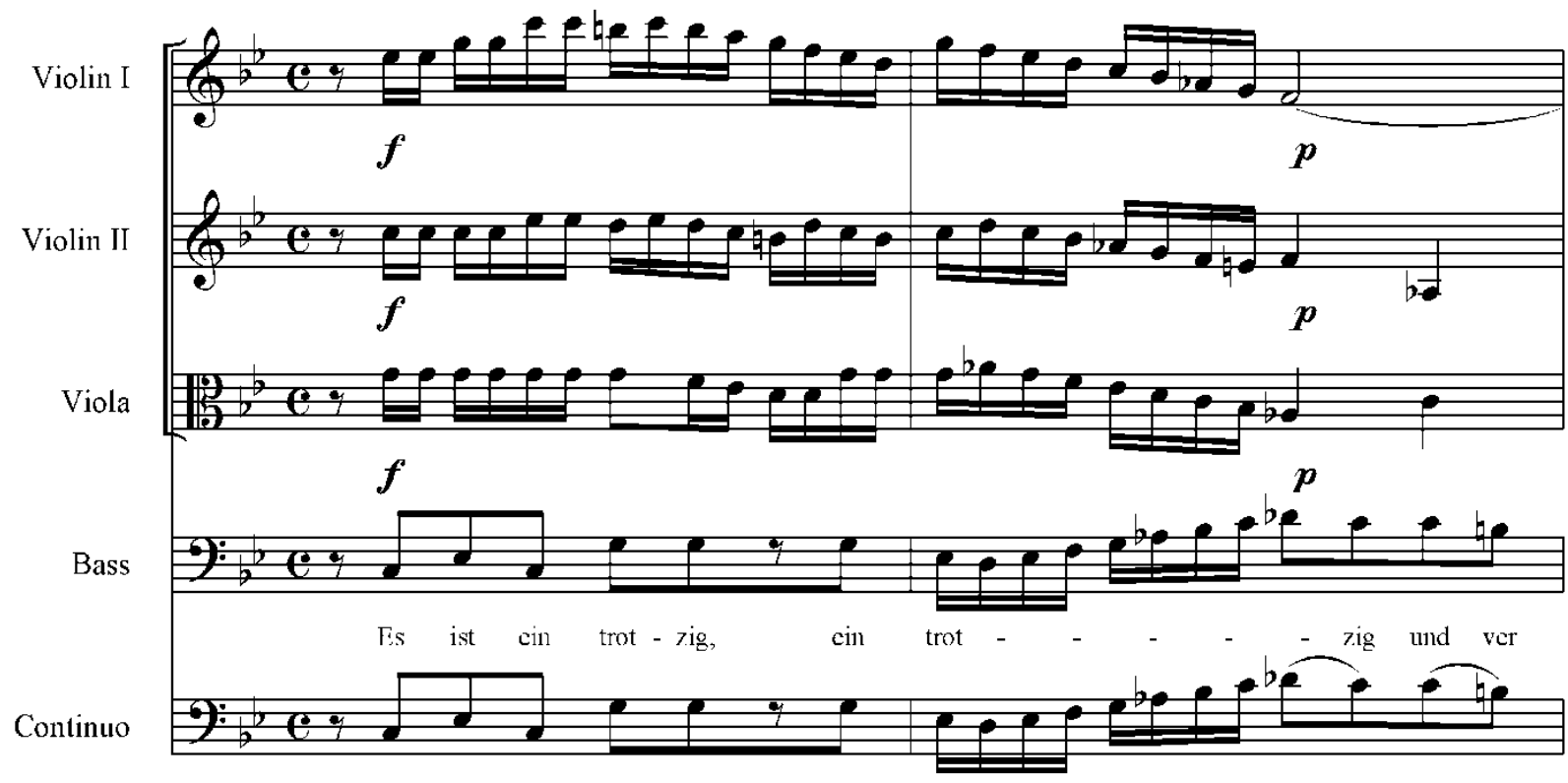

${ }^{21}$ Gardiner, "Bach Cantata Series: Cantatas for Trinity Sunday."

${ }^{22}$ Unger, Handbook to Bach's Sacred Cantata Texts: An Interlinear Translation with Reference Guide to Biblical Quotations and Allusions, 609

${ }_{23}^{23}$ Johann Sebastian Bach, Es ist ein troztig und verzagt Ding, BWV 176, ed. Alfred Dürr and Robert Freeman, Neue Ausgabe sämtlicher Werke, ser. 1, vol. 15, Kantaten (Kassel, Germany: Bärenreiter, 1967), 19. 


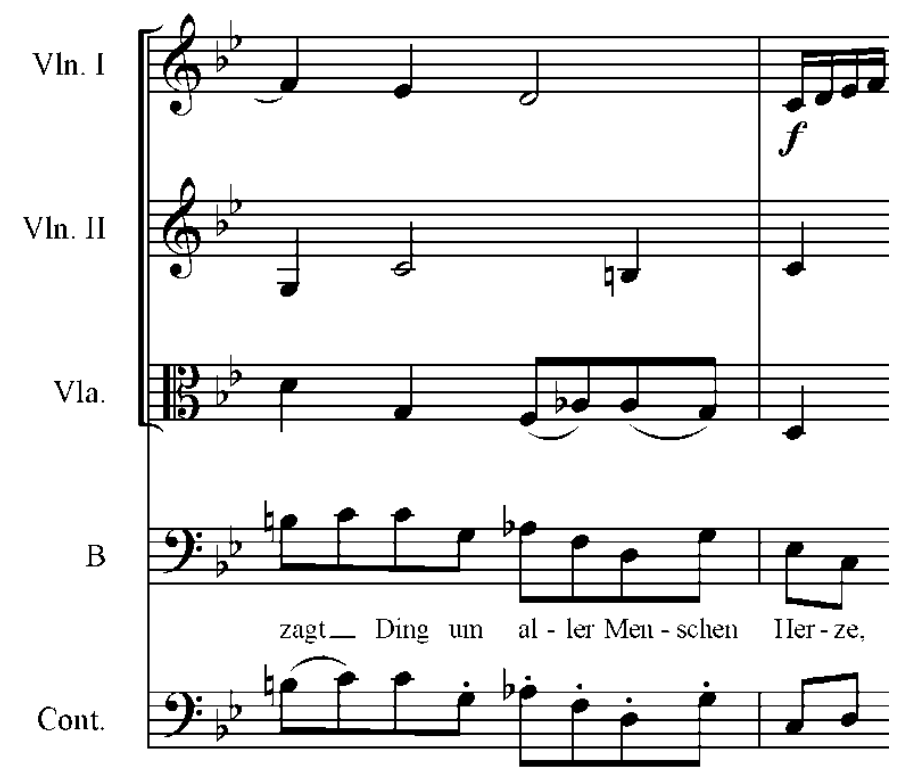

In $\mathrm{G}$ minor, the second movement, a brief secco alto recitative with basso continuo, presents another duality: imagery of Nicodemus as night with Jesus as day. ${ }^{24}$ This particular duality continues in movement three, a soprano da capo aria, with strings and basso continuo, as the light of Jesus confronts the eager but fearful and “clouded” human being. In B-flat major, this movement has a gavotte-like character. ${ }^{25}$

Dein sonst hell beliebter Schein

Thy normally bright beloved radiance

(Thy beloved radiance, normally so bright,)

Soll für mich umnebelt sein,

Must for me beclouded be, $[\text { Nebel }=\text { fog }]^{26}$

Throughout the movement, a dance-like triplet motive is expressed in the violin I part (Figure 4.2).

${ }^{24}$ Gardiner, "Bach Cantata Series: Cantatas for Trinity Sunday."

${ }^{25}$ Dürr, The Cantatas of J. S. Bach: With Their Librettos in German-English Parallel Text, 377.

${ }^{26}$ Unger, Handbook to Bach's Sacred Cantata Texts: An Interlinear Translation with Reference Guide to Biblical Quotations and Allusions, 610. 
Figure 4.2: BWV 176-3, mm. 8-16 ${ }^{27}$

Vln. I

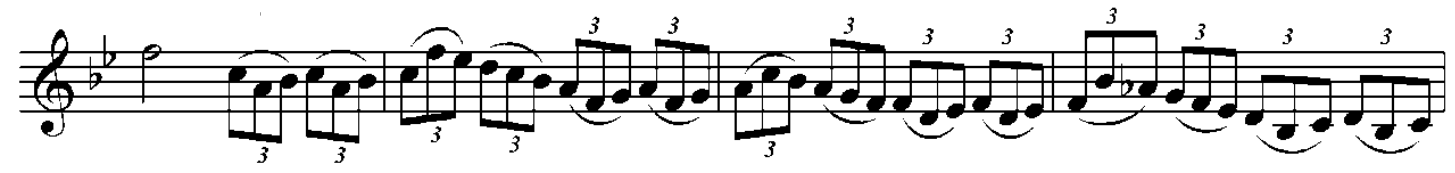

Vln. I

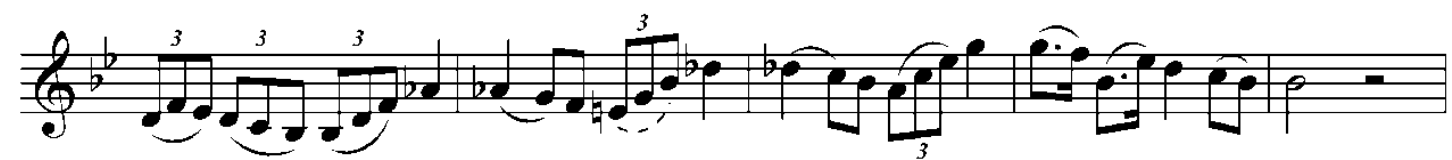

Perhaps this figure represents the spirit of God, since the only time a similar motive is present in the voice part, although briefly present, is on the textual phrases Gottes Geist (God's Spirit) and göttlich auserlesen (divinely chosen) (Figure 4.3).

Figure 4.3: BWV 176-3, mm. 59-64 ${ }^{28}$

Sop.
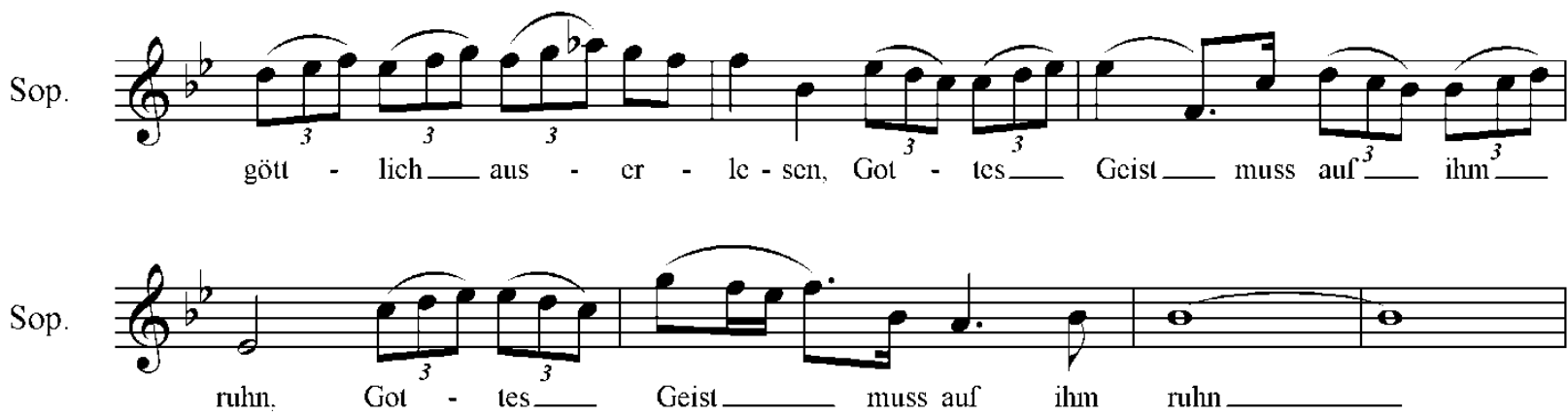

The association of the triplet motive with the Spirit of God is most apparent while the phrase Gottes Geist muß auf ihm ruhn (God's Spirit must upon him be-resting or God's Spirit must be resting upon him) is being sung. On the note for ruhn, held by the soprano for six and a half measures in one passage and four and a half measures in another passage, the triplet motive (God's Spirit) continues to dance (or "rest”) in the violin I part, above, at the same pitch of, and below the singer's note (Figure 4.4).

${ }^{27}$ Bach, Es ist ein troztig und verzagt Ding, BWV 176, 27.

${ }^{28}$ Ibid., 31. 
Figure 4.4: BWV 176-3, mm. 63-72 ${ }^{29}$
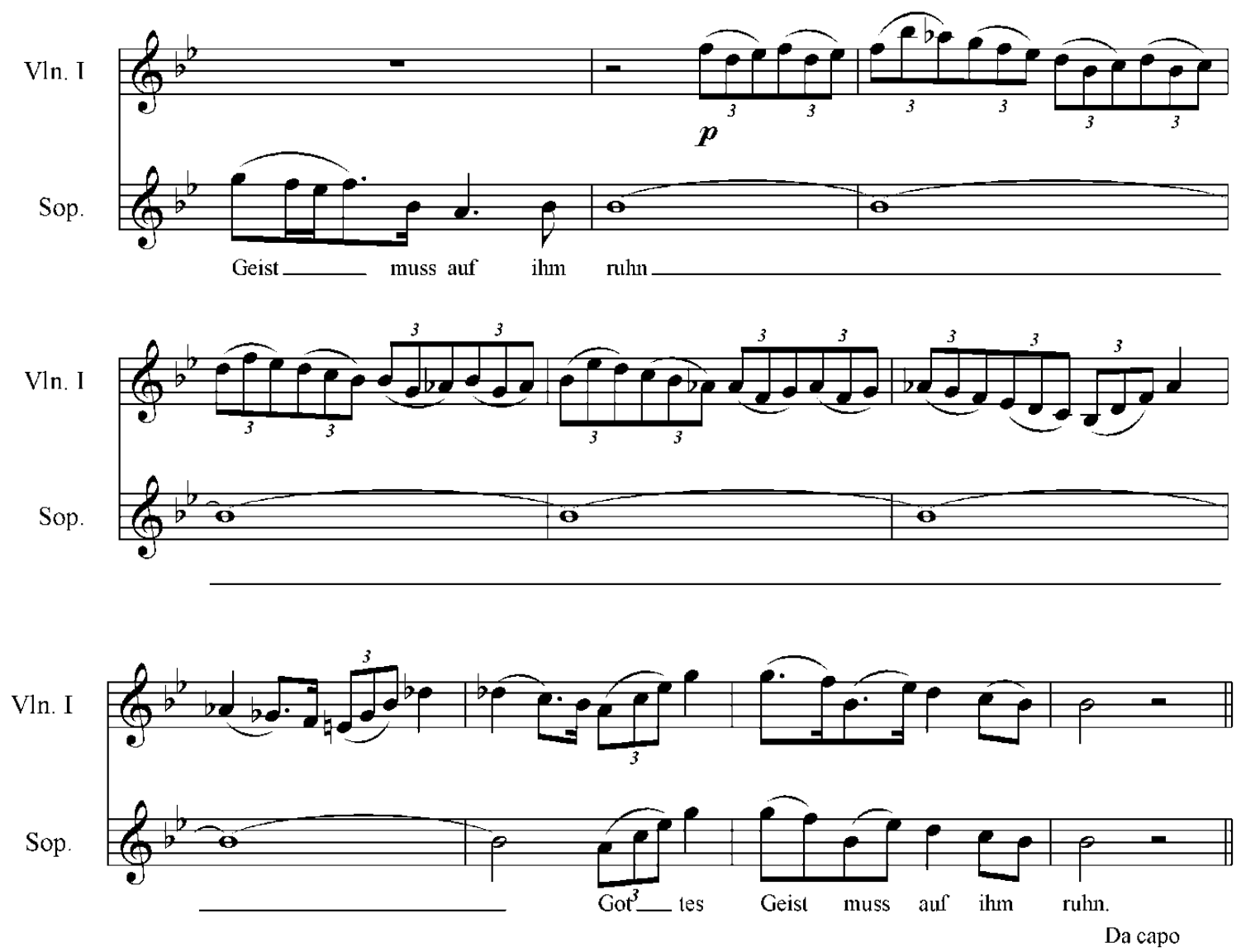

Movement 4 in $\mathrm{F}$ major and $\mathrm{C}$ minor, a secco recitative for bass with basso continuo, includes a prominent example of Bach’s modifications of Ziegler’s libretto. This movement ends with a textual passage not found in Ziegler's libretto, a paraphrase of the Gospel verse immediately following the scripture for Trinity Sunday: John 3:16. The text has been altered from scripture to speak from Nicodemus’s perspective in conversation with Jesus: ${ }^{30}$

${ }^{29}$ Bach, Es ist ein troztig und verzagt Ding, BWV 176, 31.

${ }^{30}$ Schulenberg, "Es ist ein trotzig un verzagt Ding," 164; Dürr, The Cantatas of J. S. Bach: With Their Librettos in German-English Parallel Text, 377; W. Gillies Whittaker, The Cantatas of Johann Sebastian Bach: Sacred and Secular, vol. 2 (London: Oxford University Press, 1959), 228. 
Weil alle, die nur an dich glauben, nicht verloren werden.

For all, who just in thee believe, not lost shall-be.

(For all who will just believe in thee, shall not perish.) ${ }^{31}$

The first part of the movement is realized in the typical speech-like pattern of a recitative, in common-time; however, when the text reaches the John 3:16 passage, the music becomes an extended andante arioso in three-four time. The arioso is highly expressive in both the bass and the basso continuo parts, with extended melismas on verloren (lost) that are also present in the basso continuo part. The melismas are based on the ostinato pattern in the continuo (Figure $4.5)^{32}$

Figure 4.5: BWV 176-4, mm. 12-17

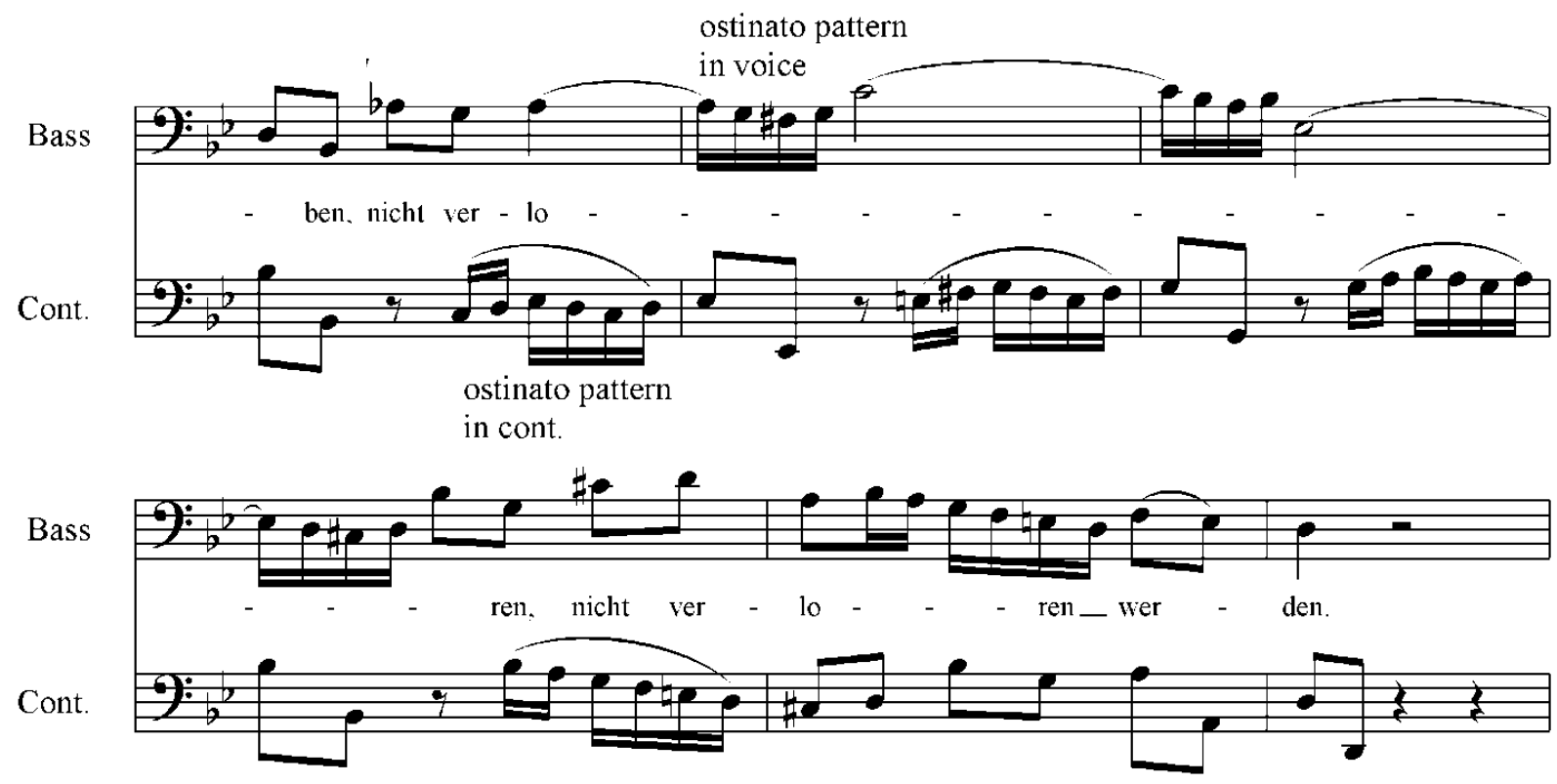

The final aria of the cantata, movement 5, is written for alto with oboes I and II, oboe da caccia, and basso continuo. In E-flat major and in three-eight time, this movement has several

\footnotetext{
${ }^{31}$ Unger, Handbook to Bach's Sacred Cantata Texts: An Interlinear Translation with Reference Guide to Biblical Quotations and Allusions, 611.

${ }^{32}$ Schulenberg, "Es ist ein trotzig un verzagt Ding," 164; Dürr, The Cantatas of J. S. Bach: With Their Librettos in German-English Parallel Text, 377.

${ }^{33}$ Bach, Es ist ein troztig und verzagt Ding, BWV 176, 32.
} 
qualities in common with the first and third movements of the cantata. In general, the fifth movement has a dance-like quality, similar to the first aria, movement three. This movement's dance is inspired by the encouraging words of the text, calling the believer to "rouse" (emuntert) and "be-renewed" (erholet) because of the promises that Jesus makes: daß ich durch den Glauben den Himmel gewinne (that I through - faith heaven obtain or that I shall obtain heaven by faith). ${ }^{34}$

Like the first movement of the cantata, both in shape and in motivation, the opening theme of this aria is directly inspired by the text. The theme rushes upward on emuntert euch (rouse yourselves) and descends chromatically by half-steps on furchtsam und schüchterne (fearful and diffident) (Figure 4.6). ${ }^{35}$ The opening theme is first introduced by the oboes in unison.

Emuntert euch, furchtsam und schüchterne Sinne, Rouse yourselves, (O) fearful and timid faculties,

Erholet euch, höret. was Jesus verspricht:

Be-renewed; hear, what Jesus promises:

Daß ich durch den Glauben den Himmel gewinne.

That I through - faith heaven obtain.

(That I shall obtain heaven by faith.) ${ }^{36}$

${ }^{34}$ Dürr, The Cantatas of J. S. Bach: With Their Librettos in German-English Parallel Text, 377.

${ }^{35}$ Ibid.; Schulenberg, "Es ist ein trotzig un verzagt Ding," 164.

${ }^{36}$ Unger, Handbook to Bach's Sacred Cantata Texts: An Interlinear Translation with Reference Guide to Biblical Quotations and Allusions, 611. 
Figure 4.6: BWV 176-5, mm. 1-16
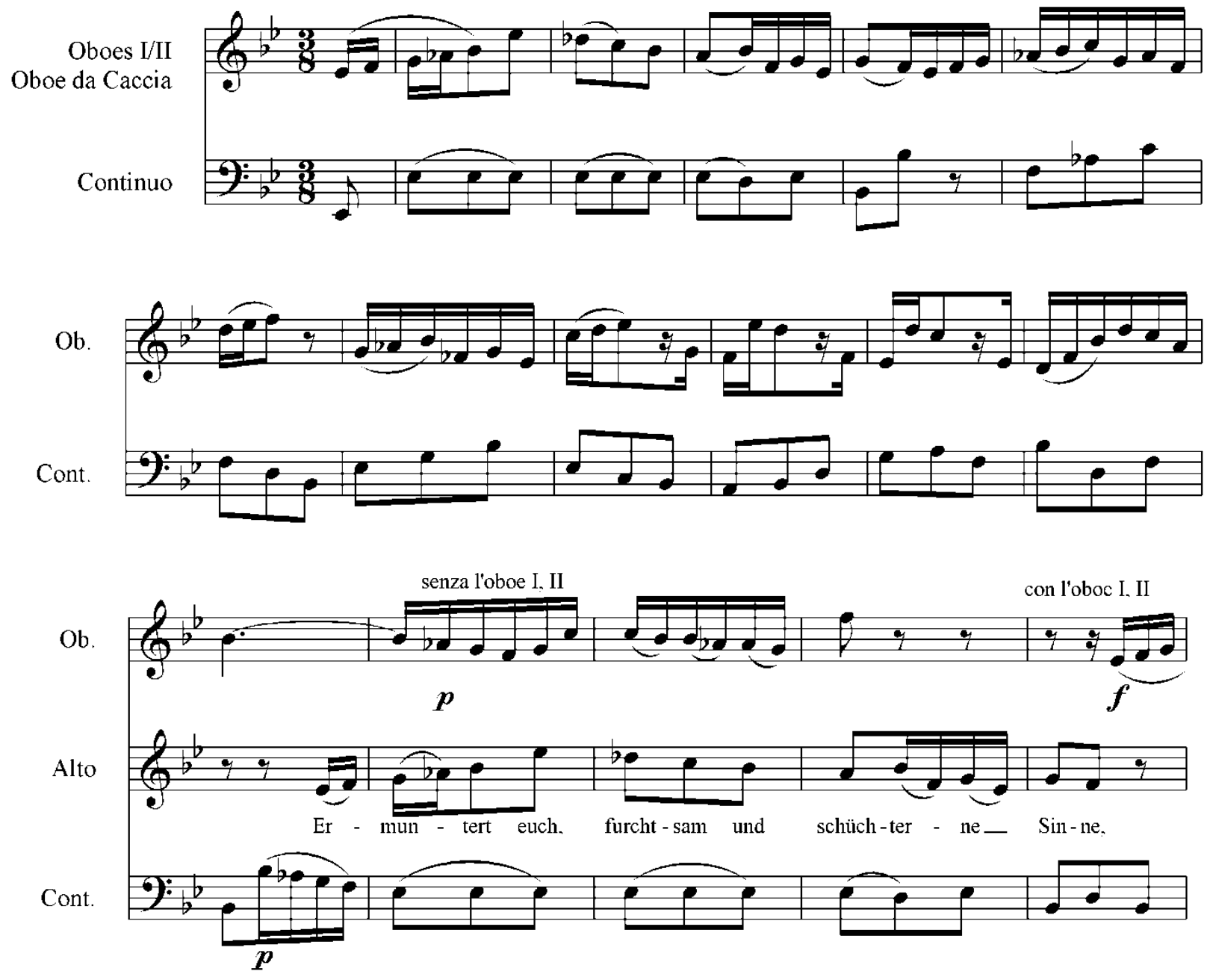

The opening theme reappears in the instrumental parts during the last of the three contrasting sections of the aria. While this theme is played again, the voice has turned to “jubilant diatonic melismas on Loben (extolling) and preisen (praise)” to the Trinity (Figure 4.7). ${ }^{38}$

Wenn die Verheißung erfüllend geschicht. When the promise (fulfillment) (achieves), (When the promise is finally fulfilled,)

${ }^{37}$ Bach, Es ist ein troztig und verzagt Ding, BWV 176, 33.

${ }^{38}$ Schulenberg, "Es ist ein trotzig un verzagt Ding," 164. 
Werd ich dort oben

Shall I up-there

Mit Danken und Loben

With giving-of-thanks and extolling

Vater, Sohn und Heilgen Geist

Father, Son, and Holy Ghost

Preisen, der dreieinig heißt.

Praise, who triune is-called.

(Up there in heaven I shall praise Father, Son, and Holy Ghost--who is called the triune God--with giving of thanks and extolling. $)^{39}$

Figure 4.7: BWV 176-5, mm. 74-91 ${ }^{40}$

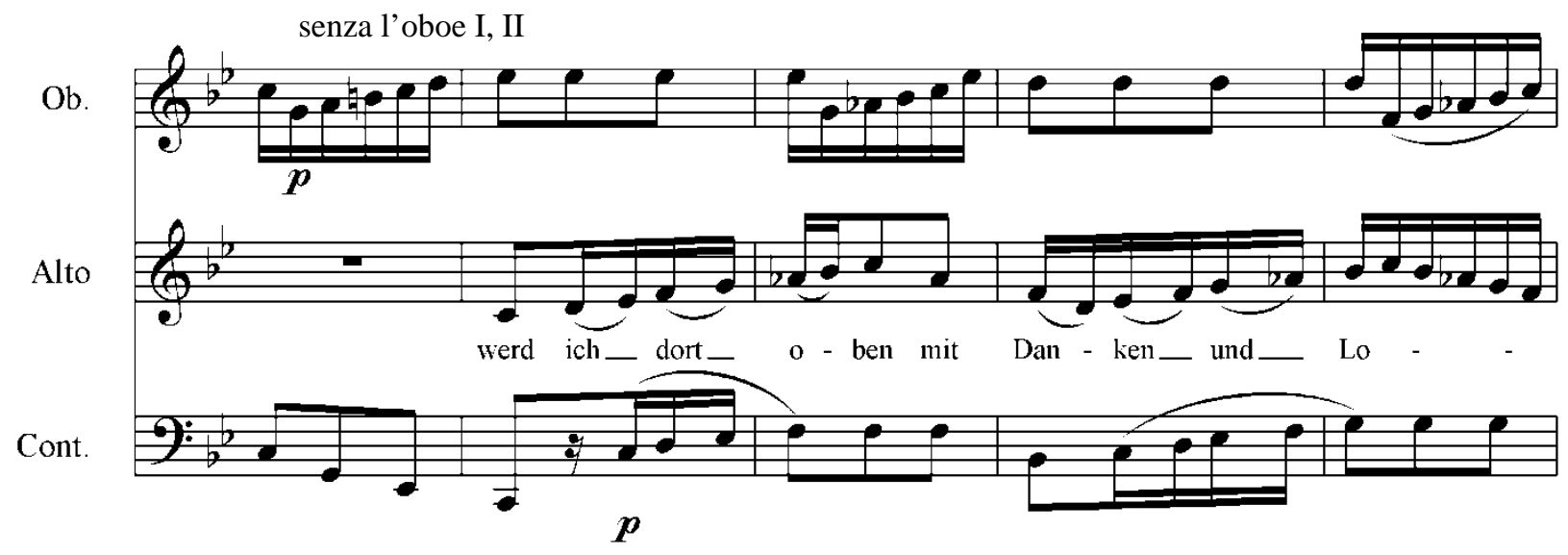

$\mathrm{Ob}$.

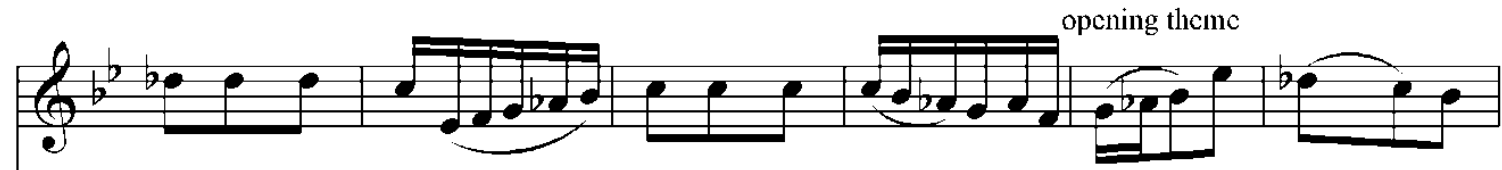

Alto

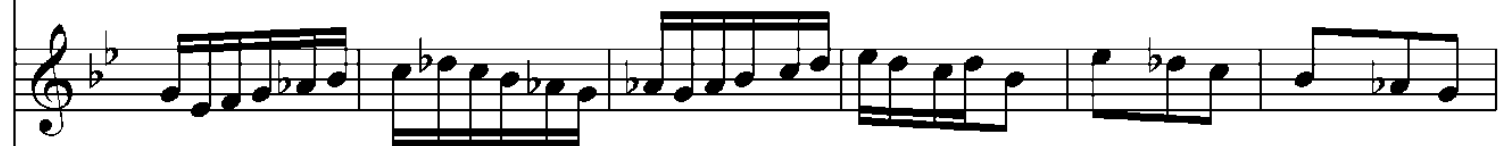

Cont

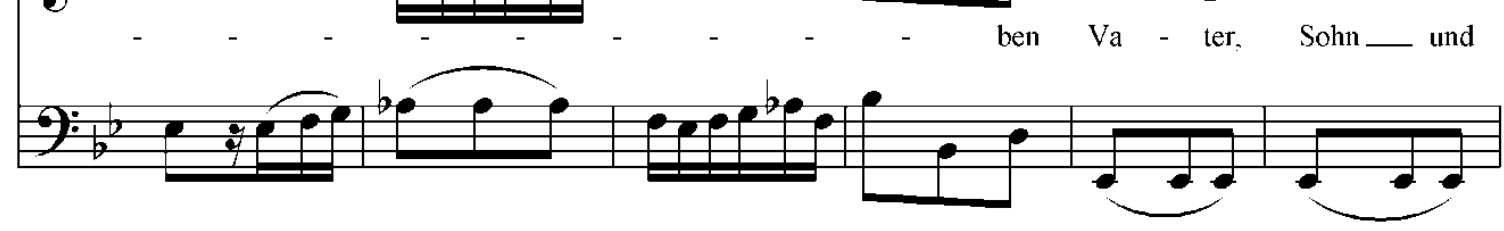

${ }^{39}$ Unger, Handbook to Bach's Sacred Cantata Texts: An Interlinear Translation with Reference Guide to Biblical Quotations and Allusions, 611-612.

${ }^{40}$ Bach, Es ist ein troztig und verzagt Ding, BWV 176, 34-35. 
$\mathrm{Ob}$.

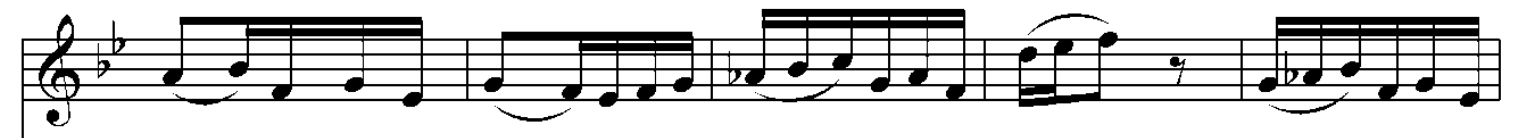

Alto

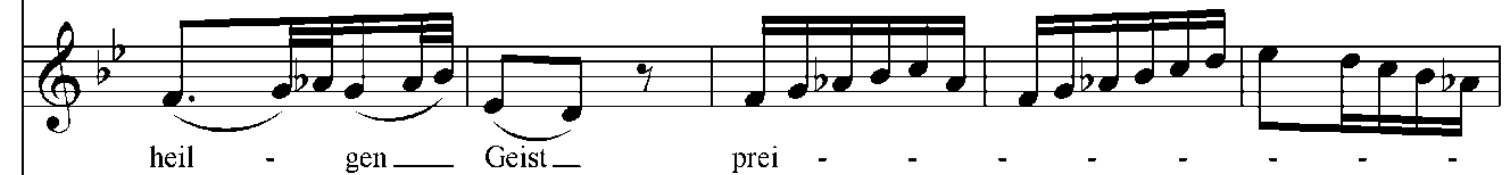

Cont.

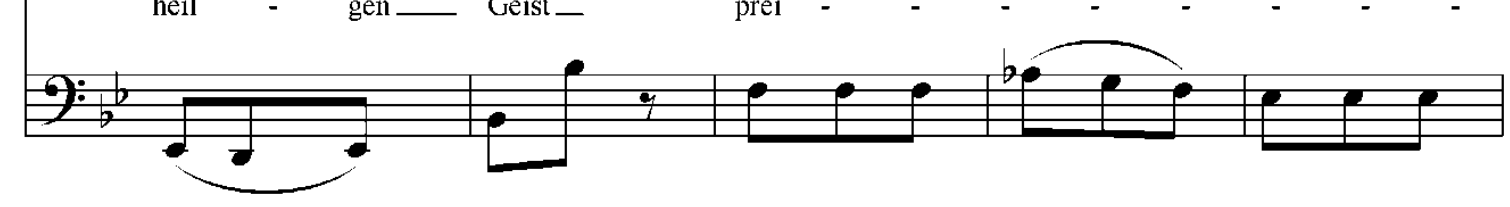

$\mathrm{Ob}$.

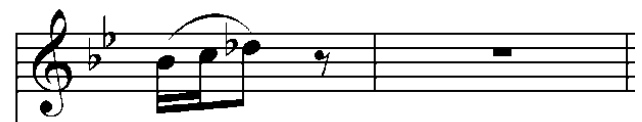

Alto

Cont.

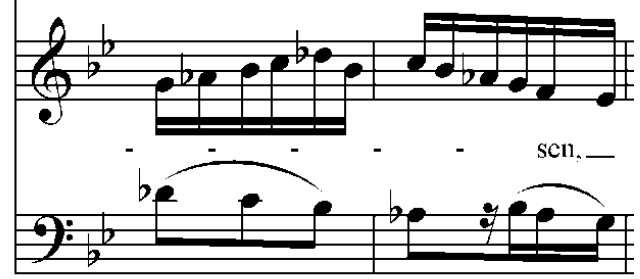

David Schulenberg and John Eliot Gardiner theorize that the three oboe parts, playing in unison during all the ritornello passages of the movement, represent the sacred Three-In-One (Father, Son, and Holy Ghost) of the Holy Trinity. ${ }^{41}$ During the vocal passages, Bach has indicated for only the oboe da caccia to play. A footnote in the Neue Bach Ausgabe indicates that this direction was added after the original version was completed and performed. ${ }^{42}$

Whittaker postulates that this reduction in parts might have been necessary due to the overwhelming sound of the unison oboes trying to balance a single alto voice. ${ }^{43}$

With the instruments of the ensemble doubling the choral parts, the cantata ends with a four-part chorale of the eighth stanza of Paul Gerhardt's Was alle Weisheit in der Welt. ${ }^{44}$ The

${ }^{41}$ Schulenberg, "Es ist ein trotzig un verzagt Ding," 164; Gardiner, "Bach Cantata Series: Cantatas for Trinity Sunday."

${ }_{42}^{42}$ Bach, Es ist ein troztig und verzagt Ding, BWV 176, 33.

${ }^{43}$ Whittaker, The Cantatas of Johann Sebastian Bach: Sacred and Secular, vol. 2, 229.

${ }^{44}$ Schulenberg, "Es ist ein trotzig un verzagt Ding," 164. 
melody of the chorale was originally part of Luther's hymn Christ unser Herr zum Jordan kam. ${ }^{45}$ In the process of the chorale, the harmonization of the F dorian-mode melody moves from E-flat major, the key of the previous movement, back to $\mathrm{C}$ minor, the key of the cantata's opening movement. ${ }^{46}$ Even though the key areas of the chorale seems a bit fluid due to the necessity of harmonizing with a modal tune, the text of the movement is a straight-forward hymn of praise to God, the Father, Son, and Holy Spirit.

Auf daß wir also allzugleich

So that we thus altogether

(Our goal is that we thus altogether)

Zur Himmelspforten dringen

To-the gates-of-heaven may-press

Und dermaleinst in deinem Reich

And hereafter in thy kingdom

Ohn alles Ende singen,

Without - end (may) sing,

Daß du allein König seist, That thou alone king art, (That thou alone art king,)

Hoch über alle Götter, High above all gods,

Gott Vater, Sohn und Heilger Geist, God (the) Father, Son and Holy Ghost,

Der Frommen Schutz und Retter, Of godly-men (the) refuge and Savior,

Ein Wesen, drei Personen.

One being (in) three persons. ${ }^{47}$

\footnotetext{
${ }^{45}$ Dürr, The Cantatas of J. S. Bach: With Their Librettos in German-English Parallel Text, 377.

${ }^{46}$ Schulenberg, "Es ist ein trotzig un verzagt Ding," 164.

${ }^{47}$ Unger, Handbook to Bach's Sacred Cantata Texts: An Interlinear Translation with Reference Guide to Biblical Quotations and Allusions, 612.
} 
Table 4.1: Movement Outline BWV 176

\begin{tabular}{|c|c|c|c|}
\hline Movement & Key/Time & Type & Special Notes \\
\hline 1 & $\begin{array}{l}\mathrm{C} \text { minor / common time } \\
\text { signature }\end{array}$ & $\begin{array}{l}\text { Chorus for SATB voices with } \\
\text { tutti instruments }\end{array}$ & $\begin{array}{l}\text { Grand choral movement; four- } \\
\text { part fugue with strings parts } \\
\text { similar to Brandenberg } \\
\text { Concerto No. } 5\end{array}$ \\
\hline 2 & $\begin{array}{l}\text { G minor / common time } \\
\text { signature }\end{array}$ & $\begin{array}{l}\text { Recitative for alto with basso } \\
\text { continuo }\end{array}$ & Brief secco recitative \\
\hline 3 & $\begin{array}{l}\text { B-flat major / alla breve time } \\
\text { signature }\end{array}$ & $\begin{array}{l}\text { Aria for soprano with strings } \\
\text { and basso continuo }\end{array}$ & Da capo aria; gavotte-like \\
\hline 4 & $\begin{array}{l}\text { F major and G minor / common } \\
\text { and three-four time signatures }\end{array}$ & $\begin{array}{l}\text { Recitative for bass with basso } \\
\text { continuo }\end{array}$ & $\begin{array}{l}\text { Secco recitative with extended } \\
\text { arioso section to accommodate } \\
\text { text added most likely by Bach }\end{array}$ \\
\hline 5 & $\begin{array}{l}\text { E-flat major / three-eight time } \\
\text { signature }\end{array}$ & $\begin{array}{l}\text { Aria for alto with oboes I/II, } \\
\text { oboe da caccia, and basso } \\
\text { continuo }\end{array}$ & $\begin{array}{l}\text { In three contrasting parts; } \\
\text { oboes played in unison during } \\
\text { the ritornello sections; dance- } \\
\text { like; theme similar to musical } \\
\text { subject in mvmt. } 1\end{array}$ \\
\hline 6 & $\begin{array}{l}\text { F minor and C minor / common } \\
\text { time signature }\end{array}$ & $\begin{array}{l}\text { Choral, SATB with tutti } \\
\text { instruments }\end{array}$ & $\begin{array}{l}\text { Four-part chorale setting; key } \\
\text { transitions back to key of } \\
\text { cantata’s first mvmt. }\end{array}$ \\
\hline
\end{tabular}




\section{Chapter 5: Gelobet sei der Herr, BWV 129}

Chapter 5 describes the five-movement Gelobet sei der Herr (Praised be the Lord, my God), BWV 129. Highlights of this chapter include an examination of this composition's purpose as a replacement cantata for the non-chorale cantata BWV 176; a brief historical study of the librettist of the cantata, Johann Olearius; and an analysis of Bach's brilliant use of instrumentation and motivic writing to set Olearius’s hymn in praise of the Holy Trinity.

\section{Scoring}

Gelobet sei der Herr, BWV 129, is scored for soprano, alto, and bass soloists; a four-part chorus; and an orchestra of three trumpets, timpani, flauto traverso, two oboes, oboe d'amore (oboe d'amore player also plays oboe II), two violins, viola, organ, and basso continuo. ${ }^{1}$ The movements take the following form:

Mvmt. 1 (Verse $1^{2}$ ) - Chorus: SATB choir; trumpets I-III, timpani, flauto traverso, oboes I-II, strings, organ, and basso continuo; D major; common time signature

Mvmt. 2 (Verse 2) - Aria: Bass solo; organ and basso continuo; A major; three-eight time signature

Mvmt. 3 (Verse 3) - Aria: Soprano solo; flauto traverso, violin I solo, organ, and basso continuo; C minor; alla breve time signature

Mvmt. 4 (Verse 4) - Aria: Alto solo; oboe d'amore, organ, and basso continuo; G major; six-eight time signature

Mvmt. 5 (Verse 5) - Chorale; SATB choir; trumpets I-III, timpani, flauto traverso, oboes I-II, strings, organ, and basso continuo; D major; common time signature

\footnotetext{
${ }^{1}$ David Humphreys, "Gelobet sei der Herr, mein Gott," In Oxford Composer Companions: J. S. Bach, ed. Malcolm Boyd (Oxford: Oxford University Press, 1999), 188; Johann Sebastian Bach, Gelobet sei der Herr, mein Gott, BWV 129, ed. Alfred Dürr and Robert Freeman, Neue Ausgabe sämtlicher Werke, ser. 1, vol. 15, Kantaten (Kassel, Germany: Bärenreiter, 1967), 38-84.

2 The verse numbers indicate the verse of librettist Johann Olearius's hymn on which the cantata is based. See the libretto section of this chapter for more information.
} 


\section{Performance/Compositional History}

The date of the first performance of BWV 129 is uncertain. It was most likely first performed in Leipzig on Trinity Sunday, June 16, 1726; however, it is also possible that it was first heard on Reformation Sunday, October 31, $1726 .{ }^{3}$ The cantata was also performed in Leipzig on Trinity Sunday, June 8, $1732 .{ }^{4}$ The chorale cantata BWV 129 was written “retrospectively for the cycle of 1724-25," (Jahrgang II) along with other cantatas that were intended to "replace the non-chorale-based compositions." In Chapter 3 of this document, a description was given of the cessation in the cycle of chorale cantatas after the feast of the Annunciation, 1725. At that point, the librettist Christiane Mariane von Ziegler was called upon to supply librettos for the final nine cantatas of the annual cycle, including the Trinity Sunday cantata composed for 1725, BWV $176 .{ }^{6}$ BWV 129 was written to replace BWV $176 .{ }^{7}$ Even though Bach wrote other cantatas to complete the chorale cantata cycle begun as Jahrgang II, according to current scholarship, the cycle was never completed. ${ }^{8}$

Like many of the orchestrations of Bach's Leipzig years, this cantata has a full ensemble, of strings, brass, timpani, woodwinds, organ, and basso continuo. ${ }^{9}$ Included in that group is the flauto traverso, an instrument Bach began regularly using in his compositions in the spring of 1724, and one of Bach's favorite instruments, the oboe d'amore ${ }^{10}$ For the bulb-belled, sweetsounding oboe d'amore, Bach wrote a concerto, he featured it many of his major works,

\footnotetext{
${ }^{3}$ Dürr, The Cantatas of J. S. Bach: With Their Librettos in German-English Parallel Text, 379; Humphreys, "Gelobet sei der Herr, mein Gott," 188; Christoph Wolff, et al, "Bach," Grove Music Online, Oxford Music Online, http://www.oxfordmusiconline.com/subscriber/article/grove/music/40023pg10 (accessed September 8, 2010).

${ }^{4}$ Wolff, Johann Sebastian Bach: The Learned Musician, 280.

${ }^{5}$ Dürr, The Cantatas of J. S. Bach: With Their Librettos in German-English Parallel Text, 379.

${ }^{6}$ Wolff, Johann Sebastian Bach: The Learned Musician, 275-281.

${ }^{7}$ Dürr, The Cantatas of J. S. Bach: With Their Librettos in German-English Parallel Text, 378-379.

${ }^{8}$ Wolff, Johann Sebastian Bach: The Learned Musician, 280.

${ }^{9}$ Ibid., 273.

${ }^{10}$ Ibid., 274.
} 
including the beautiful “Quia respexit” movement from Magnificat in D in which the oboe d'amore is paired with a solo soprano, and he included it in many of his secular and sacred cantatas. $^{11}$

\section{Table 5.1: Performance History of BWV 129}

\begin{tabular}{r|c|c|c}
$\begin{array}{r}\text { Date of } \\
\text { performance }\end{array}$ & June 16,1726 & $\begin{array}{c}\text { October 31, 1726 } \\
\text { (alternate possible } \\
\text { first performance } \\
\text { date) }\end{array}$ & June 8,1732 \\
\hline $\begin{array}{r}\text { Location of } \\
\text { performance }\end{array}$ & Leipzig & Leipzig & Leipzig \\
\hline $\begin{array}{r}\text { Purpose of } \\
\text { cantata }\end{array}$ & $\begin{array}{c}\text { Trinity Sunday } \\
\text { cantata }\end{array}$ & $\begin{array}{c}\text { Reformation Sunday } \\
\text { cantata }\end{array}$ & $\begin{array}{c}\text { Trinity Sunday } \\
\text { cantata }\end{array}$
\end{tabular}

\section{Libretto}

As one of the replacement cantatas written to fill in the gaps of the chorale-cantata cycle of Jahrgang II, Gelobet sei der Herr, BWV 129, was based on a single hymn by Johann Olearius, published in Olearius’s Christliche Bet-Schule (Leipzig, 1665). ${ }^{12}$ The libretto of the cantata is not a paraphrase of Olearius's words; it is his exact text, word-for-word. Each stanza of Olearius’s hymn is set for each movement in the cantata. ${ }^{13}$

Johannes Olearius (1611-1684) was born in Halle, the son of the pastor of St. Mary’s Church. At the University of Wittenberg, Olearius earned his M.A. (1632), and his D.D. (1643), and also served as a lecturer and as an adjunct member of the philosophical faculty. He was the

${ }^{11}$ Wolff, "Bach," Grove Music Online, Oxford Music Online.

${ }^{12}$ Dürr, The Cantatas of J. S. Bach: With Their Librettos in German-English Parallel Text, 379; Liberty Fund, Inc., "Online Library of Liberty - Cantata XXIX: Gelobet sei der Herr, Trinity Sunday (1732)," The Online Library of Liberty, http://oll.libertyfund.org/?option=com_staticxt\&staticfile=show.php\%3Ftitle=2056\&chapter=197301\&layout=html \&Itemid=27 (accessed September 9, 2010).

${ }^{13}$ Wolff, Johann Sebastian Bach: The Learned Musician, 280; Dürr, The Cantatas of J. S. Bach: With Their Librettos in German-English Parallel Text, 377-379. 
chief court preacher and private chaplain at Halle, appointed by Duke August of SachsenWeissenfels. Olearius was the author of a whole-Bible commentary, as well as numerous devotional works. For one of the largest and most significant German hymn books of the $17^{\text {th }}$ century, Geistlich Singe-Kunst (Leipzig, 1671), Olearius served as one of the compilers. This collection contained more than 302 hymns by Olearius. ${ }^{14}$

The text of the cantata is perfectly suited to Trinity Sunday; the cantata is a "song of praise to the triune God." 15

...verse 1 praises the Creator, God Himself, verse 2 the Son, verse 3 the Holy Spirit, and verses 4 and 5, which are united in substance, the Trinity. However, specific references to the readings for the day are absent, and since he set the text unaltered Bach made no attempt to introduce any. ${ }^{16}$

The straightforward jubilant text, with the first four stanzas/movements all beginning with the same opening line Gelobet sei der Herr (Blessed be the Lord), directly affects the bright musical content and uncomplicated form of the cantata: chorus, aria, aria, aria, and chorale. There are no recitatives and no da capo arias. ${ }^{17}$

\section{Detail of Each Movement}

The opening movement, with text that is stanza one from Olearius's hymn, is composed for four-part chorus, with the full orchestra: three trumpets, timpani, flute, two oboes, strings, and basso continuo. In D major, this movement begins as a bright and festive concertato for strings and woodwinds, with interjections from the trumpets and timpani. ${ }^{18}$ This music is

\footnotetext{
${ }^{14}$ John Julian, “Olearius, Johannes” from Dictionary of Hymnology (1907), Hymnary.org, Calvin College, Grand Rapids, MI, http://www.hymnary.org/person/Olearius_J (accessed September 6, 2010).

${ }^{15}$ Dürr, The Cantatas of J. S. Bach: With Their Librettos in German-English Parallel Text, 379.

16 Ibid.

${ }^{17}$ Humphreys, "Gelobet sei der Herr, mein Gott," 188.

${ }^{18}$ Dürr, The Cantatas of J. S. Bach: With Their Librettos in German-English Parallel Text, 379.
} 
forthright and grand, in praise of the first Person of the Holy Trinity: God, the Father

(Figure 5.1).

Figure 5.1: BWV 129-1, mm. 1-6 ${ }^{19}$

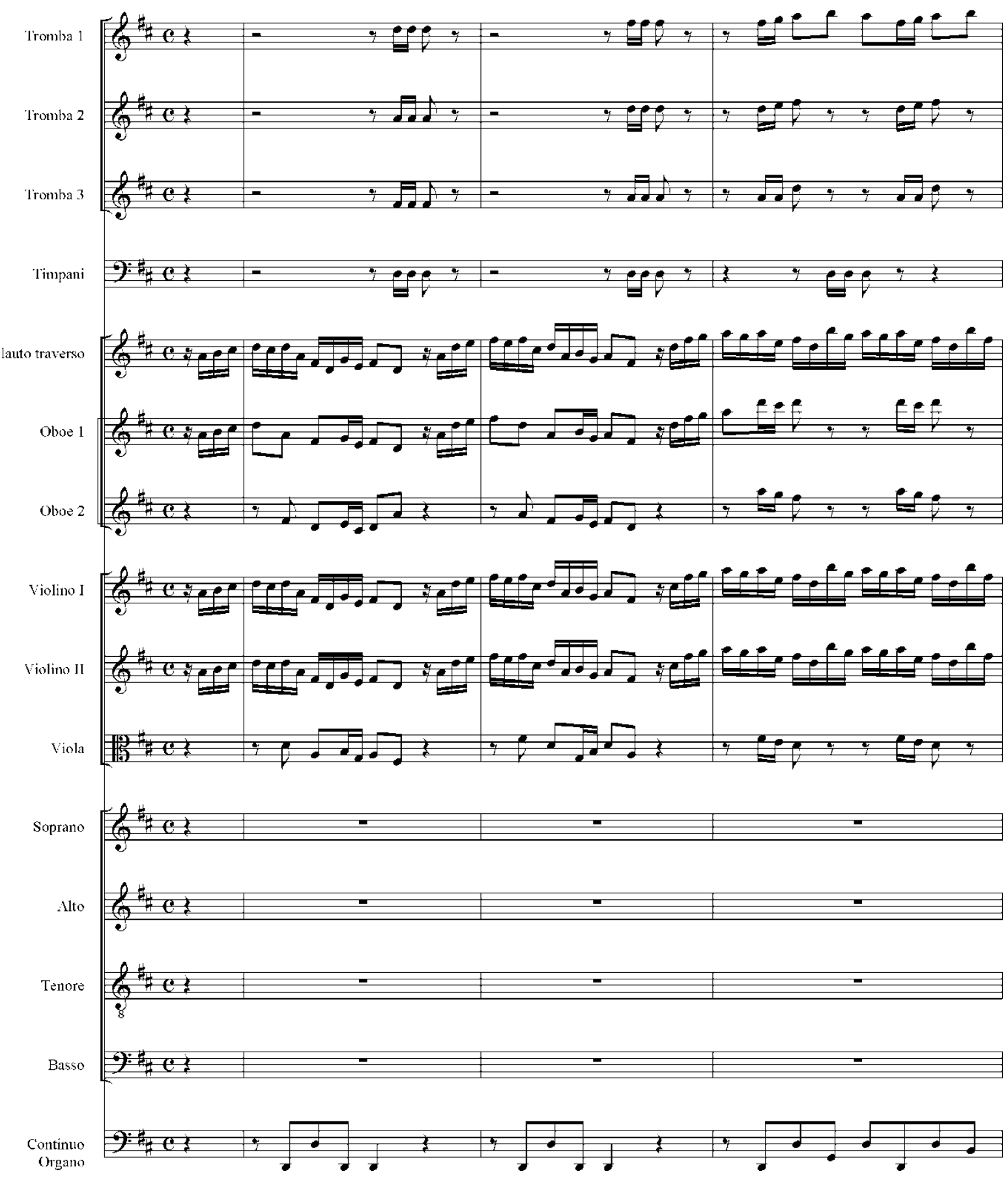

${ }^{19}$ Bach, Gelobet sei der Herr, mein Gott, BWV 129, 39-40. 


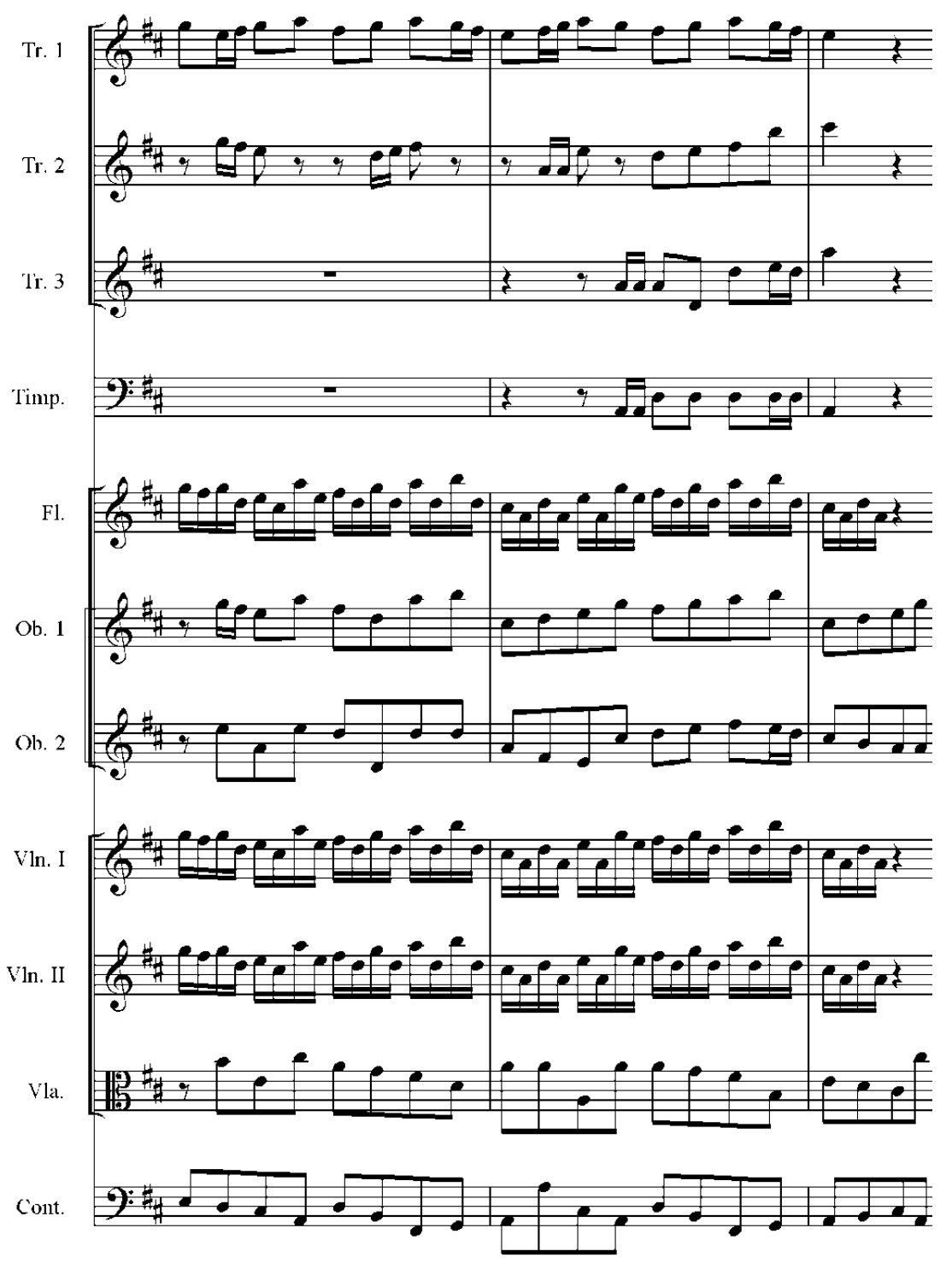

The sopranos of the chorus sing the cantus firmus - the anonymously composed melody

O Gott, du frommer Gott (O God, Thou faithful God) - while the lower voices (Alto, Tenor, and

Bass) join with material that is unconnected thematically to the cantus firmus, but imitative within the lower three parts, freely polyphonic, or chordal. ${ }^{20}$ Likewise, the instruments also

\footnotetext{
${ }^{20}$ Dürr, The Cantatas of J. S. Bach: With Their Librettos in German-English Parallel Text, 379;
} Humphreys, "Gelobet sei der Herr, mein Gott," 188; Catherine Winkworth, trans., "Online Library of Liberty - $O$ Gott, du frommer Gott," The Online Library of Liberty, http://oll.libertyfund.org/?option=com_staticxt\&staticfile= show.php\%3Ftitle=2057\&chapter=197699\&layout=html\&Itemid=27 (accessed October 1, 2010); Whittaker, The Cantatas of Johann Sebastian Bach: Sacred and Secular, vol. 1, 440. 
present music that is thematically independent from the soprano part's cantus firmus, but motivically connected to the lower three voice parts (Figure 5.2). ${ }^{21}$ Most likely, Bach's congregations knew the cantus firmus tune, as well the text that was usually associated with the tune by the same name. Like the cantatas' scriptural allusions, mentioned previously in this document, the congregations' knowledge of the hymn $O$ Gott, du frommer Gott subconsciously informed the message of this cantata movement. The text of the hymn, like the cantata movement, is a hymn of praise to the Holy Trinity, as well as a hymn of encouragement for believers to be faithful servants of God in the world. Following is an excerpt of the hymn O Gott, du frommer Gott:

Verse 1

O God, Thou faithful God, Thou Fountain ever flowing, Without Whom nothing is, All perfect gifts bestowing; A pure and healthy frame $\mathrm{O}$ give me, and within A conscience free from blame, A soul unhurt by sin.

Verse 2

And grant me, Lord, to do, With ready heart and willing, Whate'er Thou shalt command, My calling here fulfilling, And do it when I ought, With all my strength, and bless The work I thus have wrought, For Thou must give success.

\footnotetext{
${ }^{21}$ Dürr, The Cantatas of J. S. Bach: With Their Librettos in German-English Parallel Text, 379.
} 
Verse 9

To Thee, God Father, laud

Be now and evermore;

O God the Son receive

The love our full hearts store;

God Holy Ghost, Thy fame

From day to day increase;

O blessed Three in One

Thy praises ne'er shall cease. ${ }^{22}$

${ }^{22}$ Winkworth, “Online Library of Liberty - O Gott, du frommer Gott.” 
Figure 5.2: BWV 129-1, mm. 19-22 ${ }^{23}$

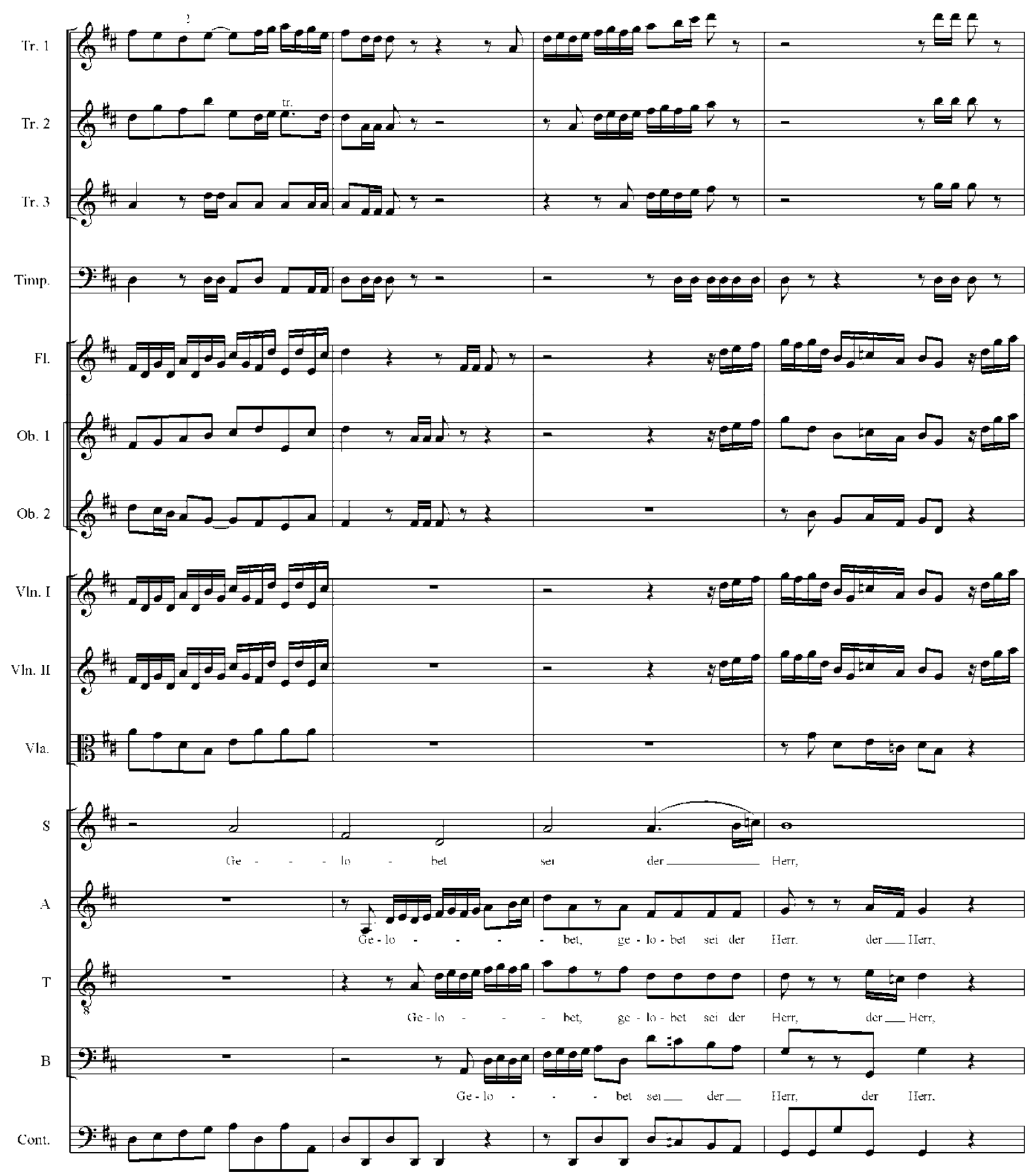

The movement ends with a return to the opening instrumental passage.

${ }^{23}$ Bach, Gelobet sei der Herr, mein Gott, BWV 129, 43-44. 
Movement 2, an aria for bass and basso continuo, is written in the key of A major. In contrast with the grand and jubilant opening movement to God the Father, this movement is a much more intimate and personal composition in praise of the second aspect of the Trinity: God the Son. ${ }^{24}$ The intimacy is created by the simple paring of soloist and continuo; the personal quality is created by a text about the individual's relationship with God, as mein Heil (my salvation), and mein Leben (my life).

Gelobet sei der Herr, Blessed be the Lord.

Mein Gott, mein Heil, mein Leben, My God, my salvation, my life,

Des Vaters liebster Sohn, The Father's dearest Son,

Der sich für mich gegeben.

Who himself for me did-give, (Who gave himself for me,) ${ }^{25}$

Helmut Rilling cites the opening basso continuo line, with juxtaposed high and low ranges, as a musical example of God from on high brought down to earth, in the person of Jesus (Figure 5.3). ${ }^{26}$

Figure 5.3: BWV 129-2, mm. 1-16 ${ }^{27}$

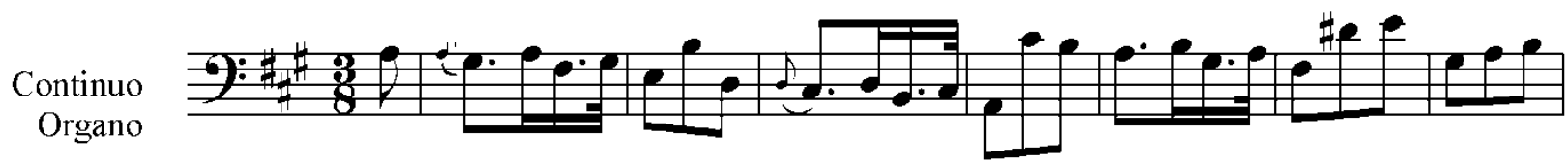

\footnotetext{
${ }^{24}$ Humphreys, "Gelobet sei der Herr, mein Gott," 188; Dürr, The Cantatas of J. S. Bach: With Their Librettos in German-English Parallel Text, 379.

${ }^{25}$ Unger, Handbook to Bach's Sacred Cantata Texts: An Interlinear Translation with Reference Guide to Biblical Quotations and Allusions, 448-449.

${ }^{26}$ Helmut Rilling, Helmuth Rilling: The Oregon Bach Festival Master Class Lectures, Volume II, 1982, 1983 -- part I, ed. Marla Lowen (Dayton, OH: Roger Dean, 2000), 82.

${ }^{27}$ Bach, Gelobet sei der Herr, mein Gott, BWV 129, 63.
} 
Cont.

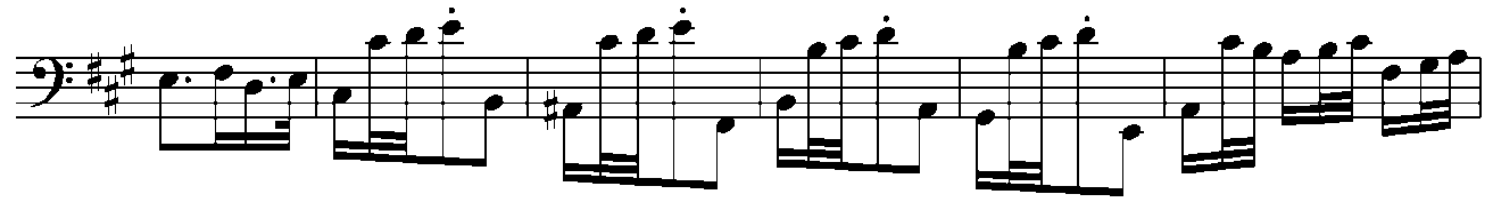

Cont.

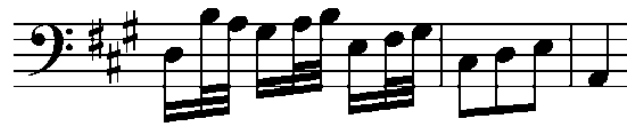

The same pattern of high/low basso continuo playing resumes when the text first mentions des Vaters liebster Sohn (the Father's dearest Son) (Figure 5.4). ${ }^{28}$

Figure 5.4: BWV 129-2, mm. 44-51 29

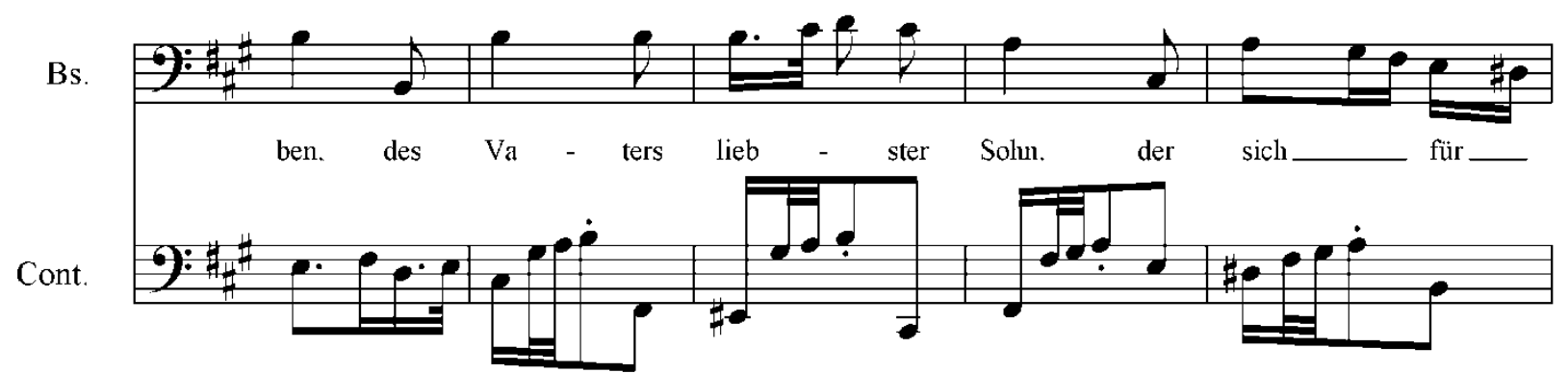

Bs.

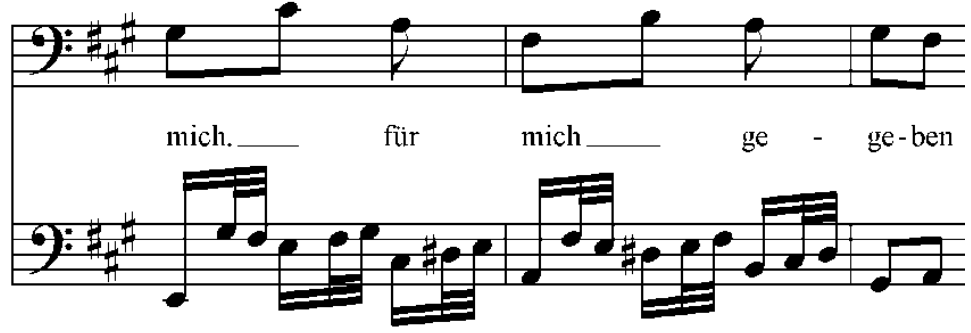

Cont.

In the middle portion of this aria, when the text comes to the account of Jesus' shedding his blood for the redemption of humanity, Bach sets a very tender phrase. After measures of alternating motivic movement between the bass voice and the basso continuo part, the final measures come to a definitive rhythmical and harmonic cadence, as seinem teuren Blut (his part I, 83

${ }^{28}$ Rilling, Helmuth Rilling: The Oregon Bach Festival Master Class Lectures, Volume II, 1982, 1983 --

${ }^{29}$ Bach, Gelobet sei der Herr, mein Gott, BWV 129, 63-64. 
precious blood) is sung. ${ }^{30}$ Just previous to this cadence, Bach highlights one of the most important words of the phrase and one of the most important words in Christian theology, erlöset (redeemed), with two melismatic passages (Figure 5.5).

Der mich erlöset hat

Who me redeemed hath

(Who redeemed me)

Mit seinem teuren Blut, With his precious blood,

Figure 5.5: BWV 129-2, mm. 78-86 ${ }^{31}$

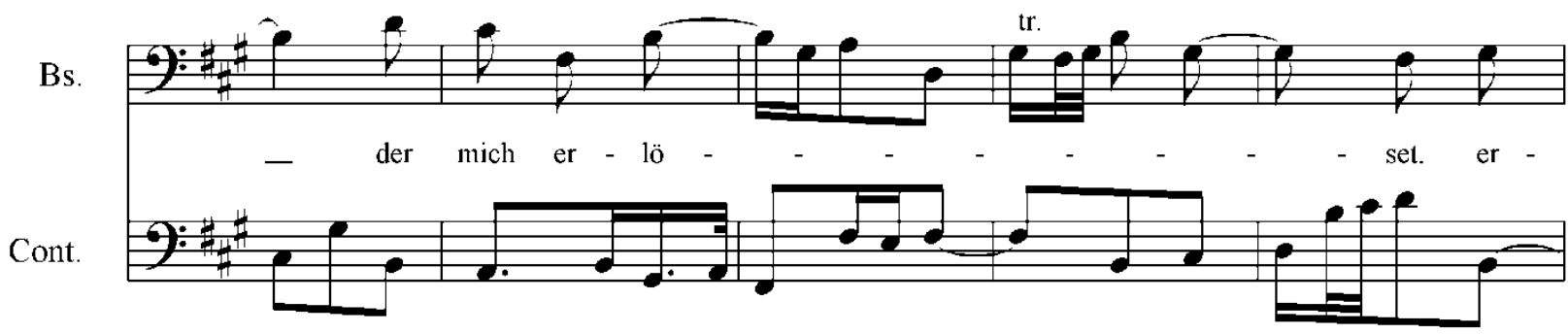

Bs.

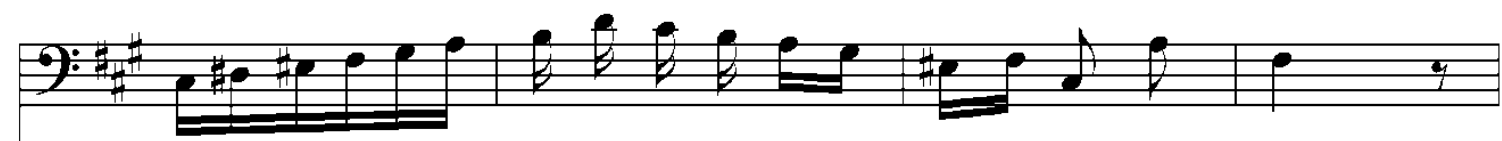

lö - - - - - sct hat mit sci - nem_ teu - ren Blut.

Cont.

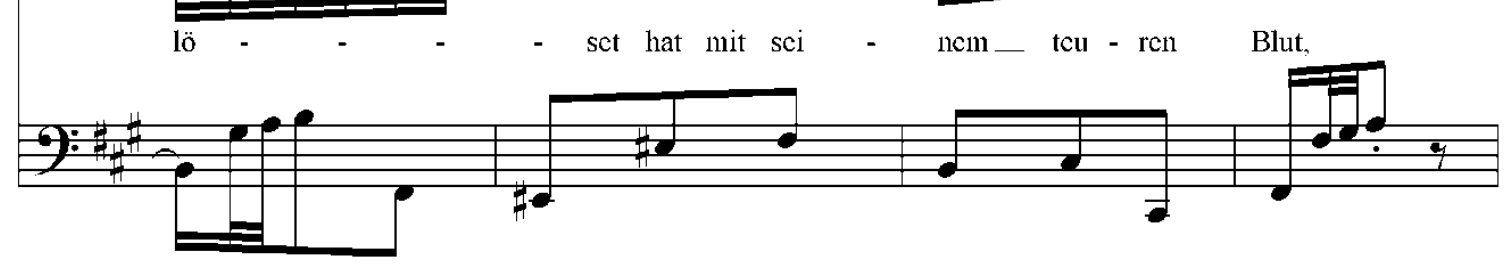

The third and final portion of the movement returns to the high/low basso continuo

playing as was heard in the first section of the aria, as the text again speaks of God offered for humanity.

Der mir im Glauben schenkt

Who to-me through faith doth-give

${ }^{30}$ Whittaker, The Cantatas of Johann Sebastian Bach: Sacred and Secular, vol. 1, 441; Rilling, Helmuth Rilling: The Oregon Bach Festival Master Class Lectures, Volume II, 1982, 1983 -- part I, 83.

${ }^{31}$ Bach, Gelobet sei der Herr, mein Gott, BWV 129, 64. 
Sich selbst. das höchste Gut.

Him-self, the highest good.

(Who gives himself, the highest good, to me by faith.) ${ }^{32}$

The third movement, an aria for soprano with flauto traverso, violin I solo, and basso continuo, sets the third verse of Olearius’s hymn text. This verse, set in E minor, is a song of praise for the third Person of the Holy Trinity: God the Spirit. ${ }^{33}$ This movement is much longer and more elaborate than the previous movement, and is driven by a "persistent semiquaver figure probably meant to suggest the Holy Spirit as a flame, or a 'rushing mighty wind." ’34 This motive is passed around to every instrument throughout the movement; however, the soprano never sings it (Figure 5.6).

Figure 5.6: BWV 129-3, mm. 1-8

Flauto traverso

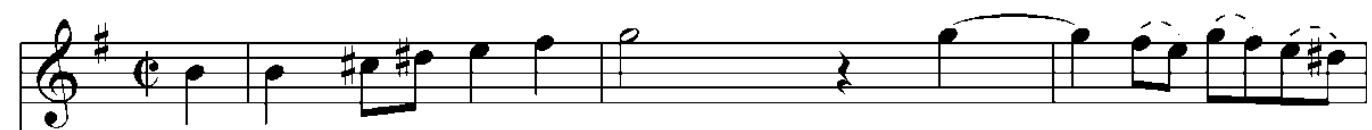

Violino solo

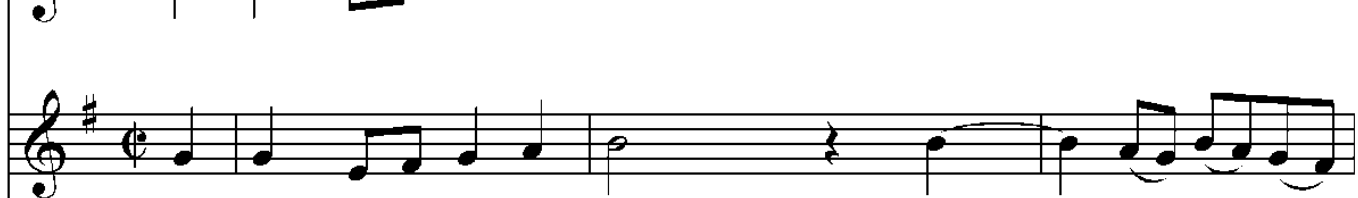

Continuo

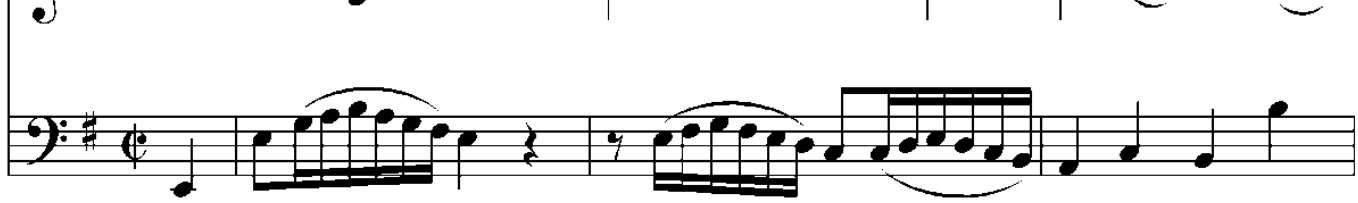

Organo Biblical Quotations and Allusions, 449.

${ }^{33}$ Dürr, The Cantatas of J. S. Bach: With Their Librettos in German-English Parallel Text, 378-379.

${ }^{34}$ Humphreys, "Gelobet sei der Herr, mein Gott," 188.

${ }^{35}$ Bach, Gelobet sei der Herr, mein Gott, BWV 129, 66. 


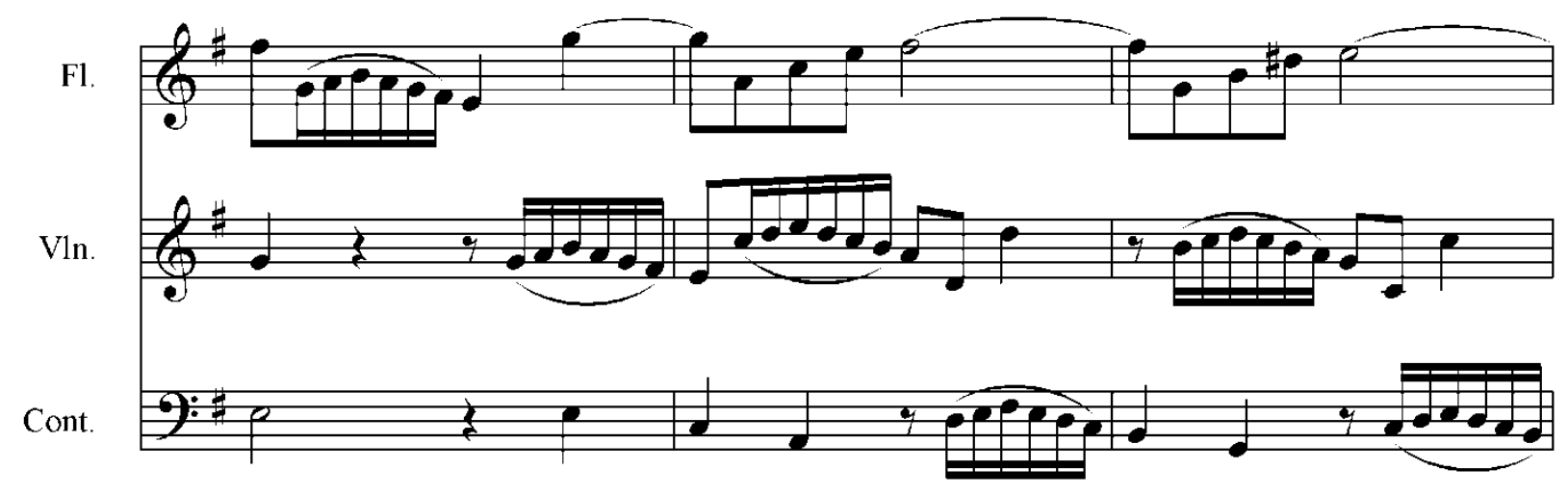

F1.
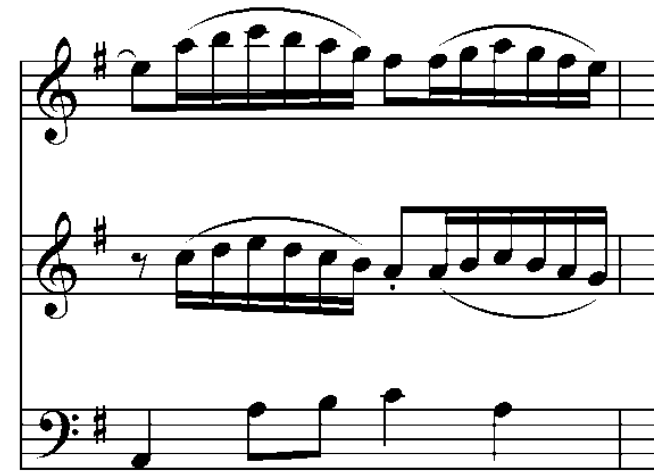

Cont.

The fourth movement, an aria for alto, oboe d'amore, and basso continuo, sets the fourth verse of Olearius's hymn. In G major, this composition is in a pastoral style and is almost dancelike, with the time signature of six-eight. ${ }^{36}$ David Humphreys suggests that the imagery of nature suggested in the text may have inspired Bach to create this pastoral setting: den alles lobet, was in allen Lüften schwebt (whom all-things praise, that in all-the [skies] do-hover or whom all things that hover in all the skies do praise). ${ }^{37}$ Providing a sense of a "homogenous texture" throughout the movement, each part plays and sings the opening eight-note motive first presented by the oboe d'amore (Figure 5.7). ${ }^{38}$

${ }^{36}$ Dürr, The Cantatas of J. S. Bach: With Their Librettos in German-English Parallel Text, 380; Humphreys, "Gelobet sei der Herr, mein Gott," 188.

${ }^{37}$ Humphreys, "Gelobet sei der Herr, mein Gott," 188.

${ }^{38}$ Dürr, The Cantatas of J. S. Bach: With Their Librettos in German-English Parallel Text, 380. 
Figure 5.7: BWV 129-4, mm. 1-8

Oboe d'amore



$\mathrm{Ob}$.

Continuo

Organo

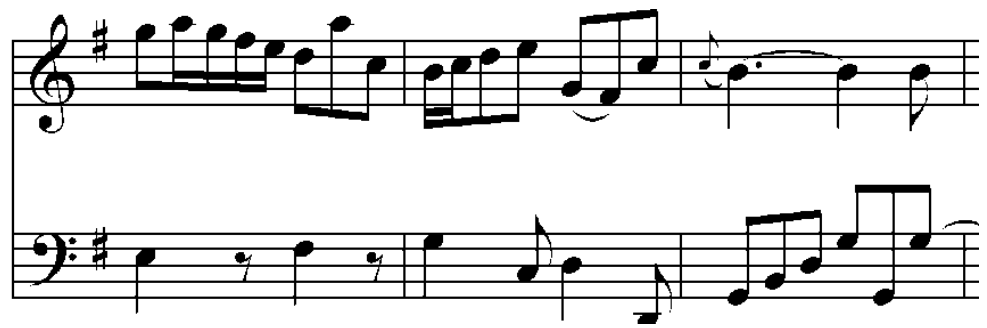

The alto picks up the motive when she begins her part (Figure 5.8).

Gelobet sei der Herr,

Blessed be the Lord,

Mein Gott, der ewig lebet,

My God, who eternally liveth,

(My God, who lives eternally,) ${ }^{40}$

Figure 5.8: BWV 129-4, mm. 24-28 ${ }^{41}$

$\mathrm{Ob}$.

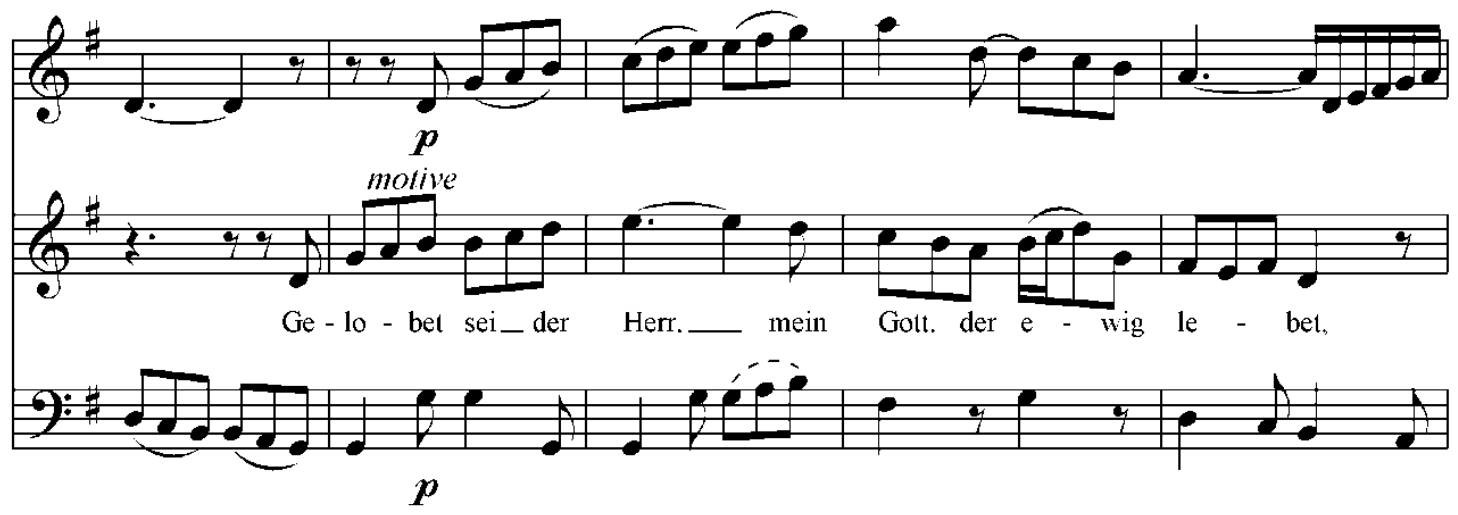

${ }^{39}$ Bach, Gelobet sei der Herr, mein Gott, BWV 129, 73.

${ }^{40}$ Unger, Handbook to Bach's Sacred Cantata Texts: An Interlinear Translation with Reference Guide to Biblical Quotations and Allusions, 450.

${ }^{41}$ Bach, Gelobet sei der Herr, mein Gott, BWV 129, 73. 
Each of the three previous movements has focused on one Person of the Holy Trinity; this movement brings together all three.

\author{
Gelobet sei der Herr, \\ Blessed be the Lord, \\ Des Name heilig heißt, \\ Whose name Holy is-called, \\ (Whose name is called Holy,) \\ Gott Vater, Gott der Sohn \\ God (the) Father, God the Son, \\ Und Gott der Heilge Geist. \\ And God the Holy Ghost. ${ }^{42}$
}

Bach sets this text in an "ingenious way" to musically portray the theology of the Holy Trinity: “One Being, Three Persons." ${ }^{, 33}$ Bach brings all three parts together in an octave-unison at the beginning of the phrase. By the time the section reaches heilge, they are fully divided into their own parts. When Geist is sung, they are once again at unison; however, this time they are singing and playing in three separate octaves (Figure 5.9). ${ }^{44}$

\footnotetext{
${ }^{42}$ Unger, Handbook to Bach's Sacred Cantata Texts: An Interlinear Translation with Reference Guide to Biblical Quotations and Allusions, 450.

${ }^{43}$ Rilling, Helmuth Rilling: The Oregon Bach Festival Master Class Lectures, Volume II, 1982, 1983 -part I, 90.

${ }^{44}$ Ibid.
} 
Figure 5.9: BWV 129-4, mm. 88-92 ${ }^{45}$

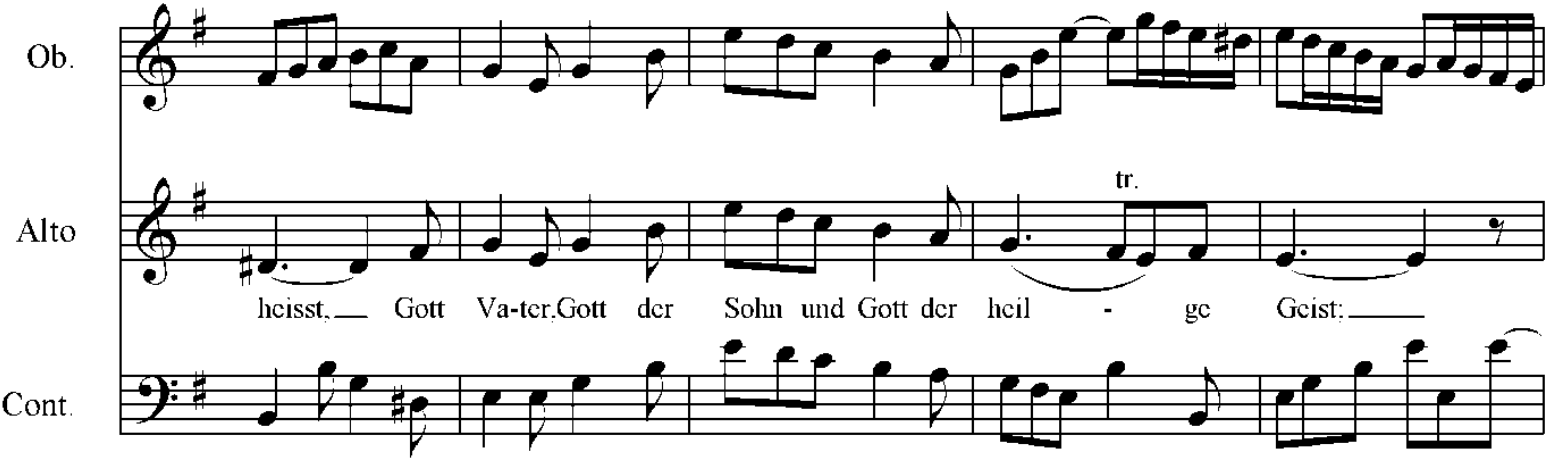

The final movement begins with fanfare and brilliance. It is a composition of pure praise. Back in D major, the key of the opening movement, this fifth movement of the cantata is built on the fifth verse of Olearius's hymn. Like the first movement, this composition is in a jubilant concertante style; the instruments provide exciting ritornellos and episodes between the stronglyframed four-part homophonic chorale settings of the text. Although the style of this movement, along with the first movement, brings sense of dynamic framing to this particular cantata, it differs greatly from the usual plain chorale settings of many Bach cantata final movements. Within the frame of the two "full-textured outer movements" lie three beautiful, intimate inner verses. $^{46}$

Of particular note in this movement are the trumpets. In the first movement, they simply mark cadences; however, in this movement, they lead the six-measure opening ritornello, and play significant roles in the instrumental episodes between the chorale phrases (Figure 5.10). ${ }^{47}$

${ }^{45}$ Bach, Gelobet sei der Herr, mein Gott, BWV 129, 76.

${ }^{46}$ Dürr, The Cantatas of J. S. Bach: With Their Librettos in German-English Parallel Text, 380.

${ }^{47}$ Ibid. 
Figure 5.10: BWV 129-5, mm. 1-6 ${ }^{48}$

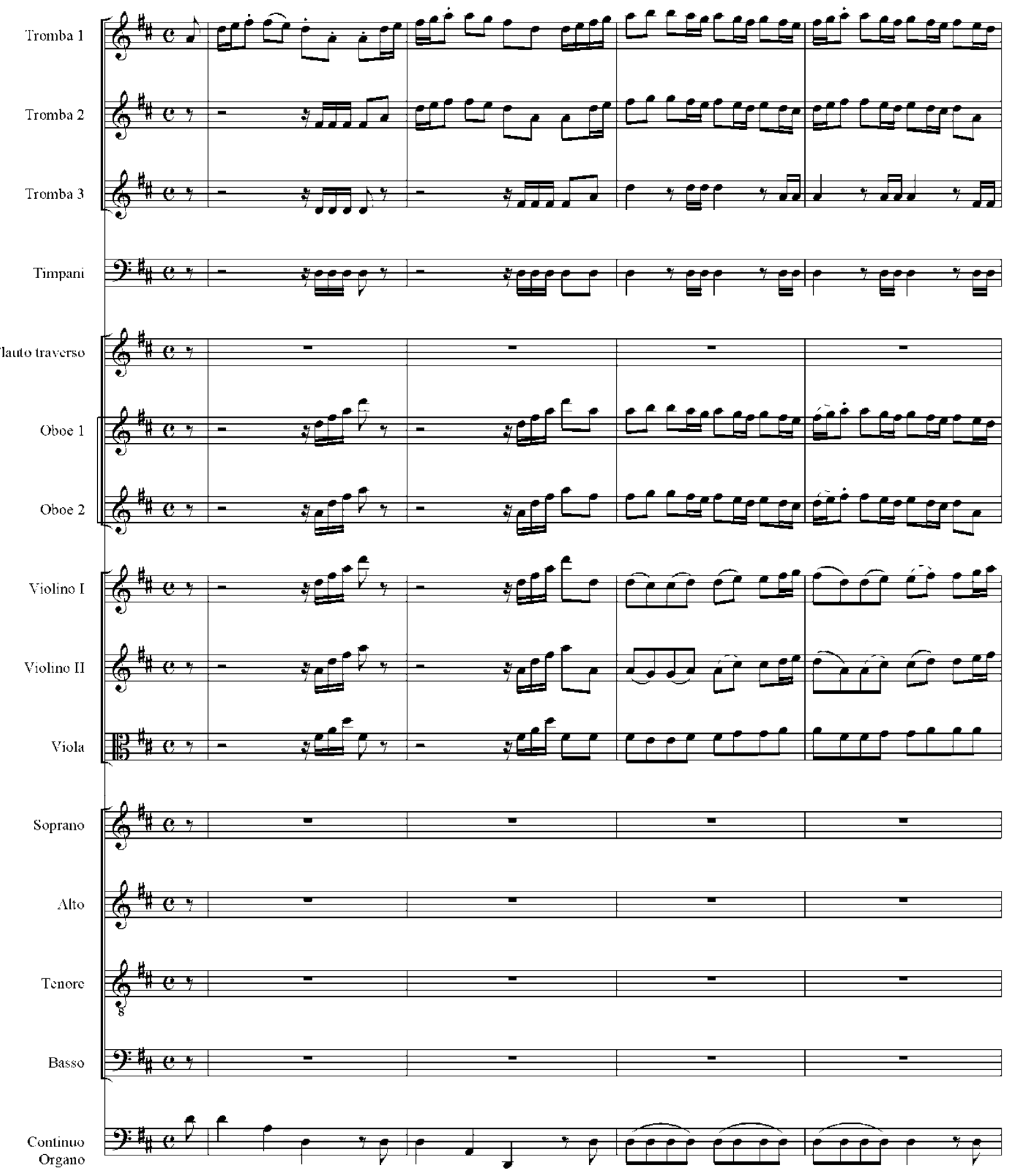

${ }^{48}$ Bach, Gelobet sei der Herr, mein Gott, BWV 129, 78-79. 


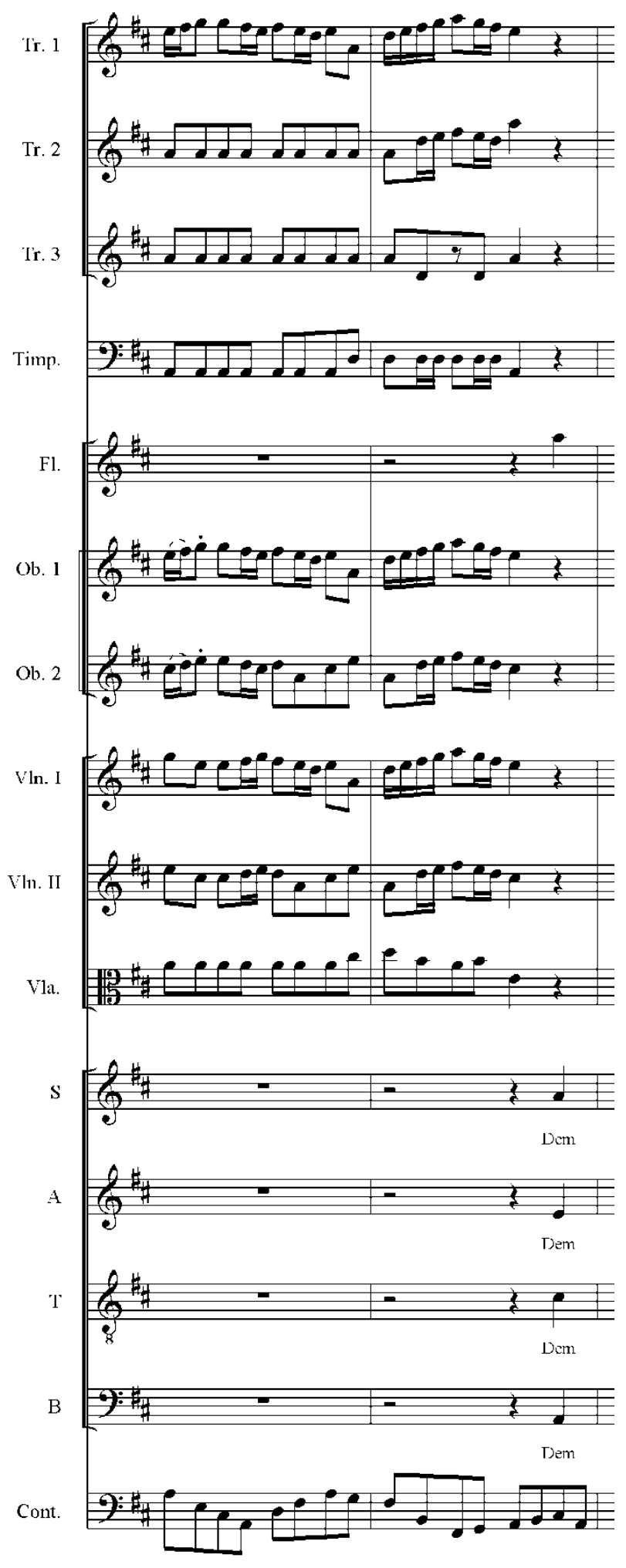

Rilling comments on the flute part throughout the movement as inspired by the chorus phrase Und mit der Engel Schar, Das Heilig, Heilig singen (And with the angel host, that "Holy, 
Holy" sing): the "flute 'sings' the chorale melody with the sopranos, but an octave higher, in the range of the angels." ${ }^{49}$ The flute doubles the sopranos at the octave throughout the movement. The flute and the basso continuo are the only instruments that play with the chorus in this movement (Figure 5.11).

Mit Freuden lassen klingen

With joy let resound

(The one to whom we now let that Sanctus joyfully resound)

Und mit der Engel Schar

And with the angel host

Das Heilig, Heilig singen,

That "Holy, Holy" sing,

${ }^{49}$ Rilling, Helmuth Rilling: The Oregon Bach Festival Master Class Lectures, Volume II, 1982, 1983 -part I, 92.

${ }^{50}$ Unger, Handbook to Bach's Sacred Cantata Texts: An Interlinear Translation with Reference Guide to Biblical Quotations and Allusions, 450. 
Figure 5.11: BWV 129-5, mm. 6-16

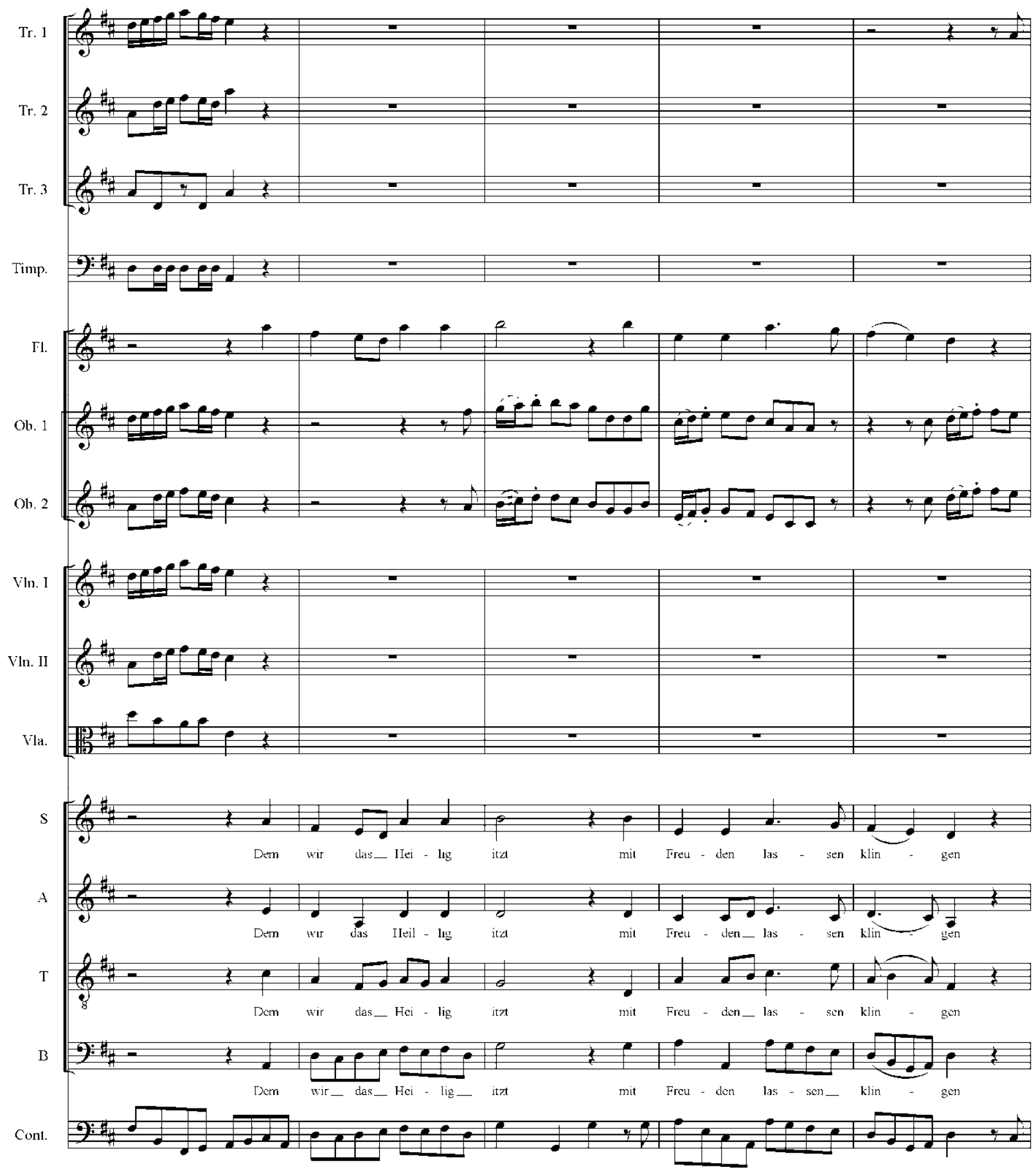

${ }^{51}$ Bach, Gelobet sei der Herr, mein Gott, BWV 129, 79-81. 


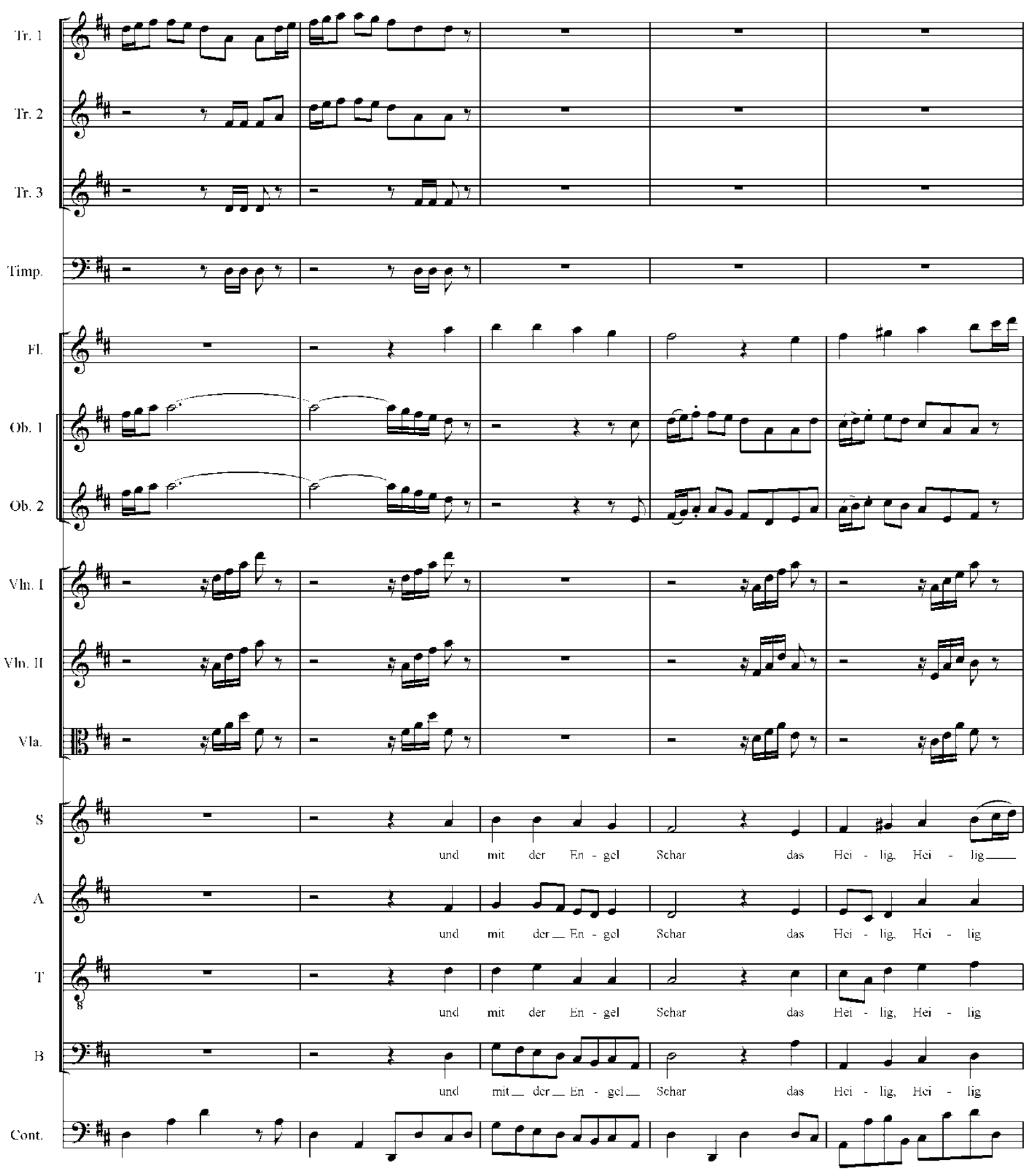




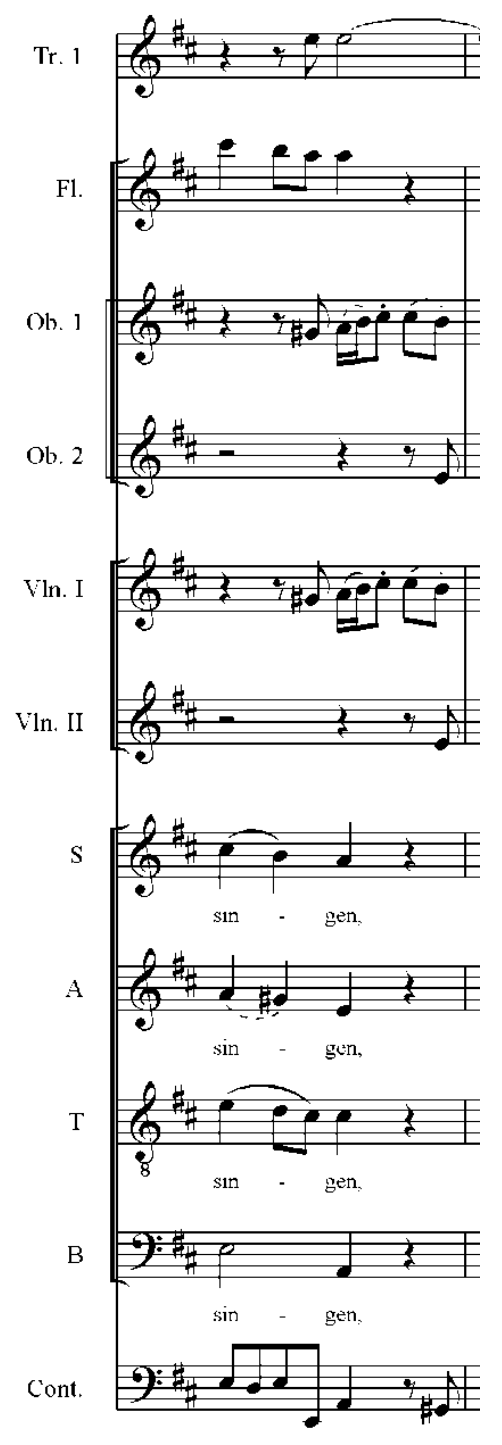

Maestro Rilling shares a final observation about the last moments of the cantata:

After the last chorale line Gelobet sei mein Gott in alle Ewigkeit! [Praised be the Lord in all eternity] Bach repeats the instrumental introduction. The piece begins anew--it could go on forever "in all eternity." ${ }^{52}$

${ }^{52}$ Rilling, Helmuth Rilling: The Oregon Bach Festival Master Class Lectures, Volume II, 1982, 1983 -part I, 95. 
Table 5.2: Movement Outline BWV 129

\begin{tabular}{|c|c|c|c|}
\hline Movement & Key/Time & Type & Special Notes \\
\hline 1 & $\begin{array}{l}\text { D major / common time } \\
\text { signature }\end{array}$ & $\begin{array}{l}\text { Chorus for SATB voices, with } \\
\text { trumpets I-III, timpani, flauto } \\
\text { traverso, oboes I-II, strings, } \\
\text { organ, and basso continuo }\end{array}$ & $\begin{array}{l}\text { Grand choral movement; bright } \\
\text { and festive concertato for } \\
\text { strings and woodwinds with } \\
\text { trumpet/timpani interjections; } \\
\text { sopranos sing cantus firmus } \\
\text { while other voices join with } \\
\text { "imitative, freely polyphonic, } \\
\text { or chordal substructure;"53 } \\
\text { Praises God the Father }\end{array}$ \\
\hline 2 & $\begin{array}{l}\text { A major / three-eight time } \\
\text { signature }\end{array}$ & $\begin{array}{l}\text { Aria for bass with organ and } \\
\text { basso continuo }\end{array}$ & $\begin{array}{l}\text { Intimate movement, } \\
\text { particularly in contrast to } \\
\text { mvmt. 1; praises God the Son; } \\
\text { features basso continuo part } \\
\text { that juxtaposes high/low } \\
\text { figures, symbolic of God come } \\
\text { down to earth }\end{array}$ \\
\hline 3 & $\begin{array}{l}\mathrm{C} \text { minor / alla breve time } \\
\text { signature }\end{array}$ & $\begin{array}{l}\text { Aria for soprano with flauto } \\
\text { traverso, violin I solo, organ, } \\
\text { and basso continuo }\end{array}$ & $\begin{array}{l}\text { In praise of God the Spirit; } \\
\text { driven by a sixteenth-note } \\
\text { motive that "suggests the Holy } \\
\text { Spirit as a flame, or a 'rushing } \\
\text { mighty wind"” } 54\end{array}$ \\
\hline 4 & $\begin{array}{l}\text { G major / six-eight time } \\
\text { signature }\end{array}$ & $\begin{array}{l}\text { Aria for alto with oboe } \\
\text { d'amore, organ, and basso } \\
\text { continuo }\end{array}$ & $\begin{array}{l}\text { Pastoral, dance-like; opening } \\
\text { motive is repeated in all } \\
\text { instruments and voices, } \\
\text { throughout the movement; } \\
\text { when the three Persons of the } \\
\text { Trinity are featured, music } \\
\text { comes to an octave-unison, } \\
\text { splits to three separate parts, } \\
\text { then joins again on a octave- } \\
\text { unison, with notes in three } \\
\text { different octaves. }\end{array}$ \\
\hline 5 & $\begin{array}{l}\text { D major / common time } \\
\text { signature }\end{array}$ & $\begin{array}{l}\text { Chorale, SATB, with trumpets } \\
\text { I-III, timpani, flauto traverso, } \\
\text { oboes I-II, strings, organ, and } \\
\text { basso continuo }\end{array}$ & $\begin{array}{l}\text { Brilliant movement; opens with } \\
\text { a fanfare; trumpets play pivotal } \\
\text { role in driving the movement, } \\
\text { more than just marking } \\
\text { cadences like in mvmt. 1; } \\
\text { chorus sings four-part } \\
\text { homophonic chorale setting of } \\
\text { the text with instrumental } \\
\text { episodes of dynamic } \\
\text { polyphonic passages }\end{array}$ \\
\hline
\end{tabular}

${ }^{53}$ Dürr, The Cantatas of J. S. Bach: With Their Librettos in German-English Parallel Text, 379.

${ }^{54}$ Humphreys, "Gelobet sei der Herr, mein Gott," 188. 


\section{Chapter 6: Overall Comparison}

One of the central elements of this research project is a comparison of the four Trinity Sunday cantatas. Since the four cantatas have been examined in detail as part of Chapters 2-5, Chapter 6 turns to comparing the discoveries that were made by studying the compositions. Common techniques and characteristics between the cantatas are identified in this chapter, with particular attention to the methods Bach used to express sacred text.

\section{Scoring}

In the Scoring subsections of Chapters 2-5, attention was focused on the instrumentation, voicing, and overall movement structure that Bach used in the four Trinity Sunday cantatas: BWV 194, 165, 176, and 129. Those three criteria are compared among the four cantatas in Table 6.1. Please note that the names of the movements in the table (recitativo, choral, chorus, chorale, etc.) were the names given by Bach in his scores. Specific commonalities and dissimilarities have been highlighted among the scoring comparisons in Table 6.2. Notable in the commonalities among all the cantatas are the use of a choral or chorale movement at the end of every cantata (and at the end of both parts of BWV 194), the use of tutti instruments in the first and last movements of each composition, and the use of soprano and bass soloists. Oboes were the most common non-string instruments used. BWV 129 was the only cantata that had no recitative movements; the only solo movements in this cantata were arias. 


\section{Table 6.1: Scoring Comparison}

\begin{tabular}{|c|c|c|c|c|}
\hline & BWV 194 & BWV 165 & BWV 176 & BWV 129 \\
\hline Voices & $\begin{array}{l}\text { soprano, tenor, and } \\
\text { bass soloists; and a } \\
\text { four-part chorus }\end{array}$ & $\begin{array}{l}\text { soprano, alto, tenor, } \\
\text { and bass soloists; and } \\
\text { a four-part chorus }\end{array}$ & $\begin{array}{l}\text { soprano, alto, and bass } \\
\text { soloists; and a four- } \\
\text { part chorus }\end{array}$ & $\begin{array}{l}\text { soprano, alto, and bass } \\
\text { soloists; and a four- } \\
\text { part chorus }\end{array}$ \\
\hline Instruments & $\begin{array}{l}\text { three oboes, bassoon, } \\
\text { two violins, viola, } \\
\text { organ, and basso } \\
\text { continuo }\end{array}$ & $\begin{array}{l}\text { two violins, viola, } \\
\text { bassoon, and basso } \\
\text { continuo }\end{array}$ & $\begin{array}{l}\text { two oboes, oboe da } \\
\text { caccia, two violins, } \\
\text { viola, and basso } \\
\text { continuo }\end{array}$ & $\begin{array}{l}\text { three trumpets, } \\
\text { timpani, flauto } \\
\text { traverso, two oboes, } \\
\text { oboe d'amore (oboe } \\
\text { d'amore player also } \\
\text { plays oboe II), two } \\
\text { violins, viola, organ, } \\
\text { and basso continuo }\end{array}$ \\
\hline Movements & $\begin{array}{l}2 \text { Parts }{ }^{1} \\
12 \text { Movements } \\
\text { Part I } \\
1 \text { - Chorus: SATB, } \\
\text { and tutti instruments } \\
2 \text { - Recitativo: bass } \\
\text { and basso continuo } \\
3 \text { - Aria: bass, oboe I, } \\
\text { strings, and basso } \\
\text { continuo } \\
4 \text { - Recitativo: soprano } \\
\text { and basso continuo } \\
5 \text { - Aria: soprano, } \\
\text { strings, and basso } \\
\text { continuo } \\
6 \text { - Chorale, SATB } \\
\text { and tutti instruments } \\
\text { basso continuo } \\
\text { Part II Recitativo: tenor } \\
\text { and basso continuo } \\
\end{array}$ & $\begin{array}{l}6 \text { Movements } \\
1 \text { - Aria: soprano and } \\
\text { tutti instruments } \\
2 \text { - Recitativo: bass } \\
\text { and basso continuo } \\
\text { 3- Aria: alto and basso } \\
\text { continuo } \\
4 \text { - Recitativo: bass, } \\
\text { strings, bassoon, and } \\
\text { basso continuo } \\
5 \text { - Aria: tenor, violins } \\
\text { I-II, and basso } \\
\text { continuo } \\
6 \text { - Chorale: SATB } \\
\text { and tutti instruments }\end{array}$ & $\begin{array}{l}6 \text { Movements } \\
1 \text { - Chorus: SATB and } \\
\text { tutti instruments } \\
2 \text { - Recitativo: alto and } \\
\text { basso continuo } \\
3 \text { - Aria - soprano, } \\
\text { strings, and basso } \\
\text { continuo } \\
4 \text { - Recitativo: bass } \\
\text { and basso continuo } \\
5 \text { - Aria: alto, oboes, } \\
\text { and basso continuo } \\
6 \text { - Choral: SATB and } \\
\text { tutti instruments }\end{array}$ & $\begin{array}{l}5 \text { Movements } \\
1 \text { - Chorus: SATB, } \\
\text { and tutti instruments } \\
\text { (no oboe d'amore) } \\
2 \text { - Aria: bass and } \\
\text { basso continuo } \\
3 \text { - Aria: soprano, } \\
\text { flute, violin solo, and } \\
\text { basso continuo } \\
4 \text { - Aria: alto, oboe } \\
\text { d'amore, and basso } \\
\text { continuo } \\
5 \text { - Chorale: SATB, } \\
\text { and tutti instruments } \\
\text { (no oboe d'amore) }\end{array}$ \\
\hline
\end{tabular}

${ }^{1}$ Both parts were not performed every time the cantata was presented. For the first Leipzig performance, only Part I was performed. Both parts were presented at the cantata's first performance in Störmthal. 


\begin{tabular}{l|l|c|c|c} 
& \multicolumn{1}{c|}{ BWV 194 } & BWV 165 & BWV 176 & BWV 129 \\
\hline $\begin{array}{l}\text { Movements } \\
\text { (cont'd) }\end{array}$ & $\begin{array}{l}\text { 9 - Recitativo Duet: } \\
\text { soprano, bass, and } \\
\text { basso continuo } \\
10 \text { - Aria: soprano, } \\
\text { bass, oboes I-II, and } \\
\text { basso continuo } \\
11 \text { - Recitativo: bass } \\
\text { and basso continuo } \\
12 \text { - Choral: SATB } \\
\text { and tutti instruments }\end{array}$ & & \\
\end{tabular}

Table 6.2: Commonalities in Scoring

\begin{tabular}{l|c|c|c|c} 
& $\boldsymbol{B W V} \mathbf{1 9 4}$ & $\boldsymbol{B W V} \mathbf{1 6 5}$ & $\boldsymbol{B W V} \mathbf{1 7 6}$ & $\boldsymbol{B W V} \mathbf{1 2 9}$ \\
\hline $\begin{array}{l}\text { Soloists, a four-part chorus, and an orchestra of } \\
\text { strings and basso continuo }\end{array}$ & yes & yes & yes & yes \\
\hline Soprano and bass soloists & yes & yes & yes & yes \\
\hline At least five movements & yes & yes & yes & yes \\
\hline Begins and end with tutti instruments & yes & yes & yes & yes \\
\hline Ends with a choral or chorale movement & yes & yes & yes & yes \\
\hline Basso continuo plays on every measure & yes & yes & yes & yes \\
\hline Alto soloist & no & yes & yes & yes \\
\hline Oboes & yes & no & yes & yes \\
\hline Recitativo and aria movements & yes & yes & yes & no \\
\hline Tenor soloist & yes & yes & no & no \\
\hline Bassoon & yes & yes & no & no
\end{tabular}

${ }^{2}$ Since the same player plays the oboe II part and the oboe d'amore in BWV 129, the oboe d'amore is not played with the tutti orchestra.

${ }^{3}$ Other comparisons of these movements will be done in this chapter's "Detail of Each Movement" section.

${ }^{4}$ This technique is standard practice for music of the early $18^{\text {th }}$ century.

${ }^{5}$ Even though only two cantatas have bassoon parts indicated as part of the continuo line, the bassoon might have played on any or all of the cantatas, because of the flexibility of the continuo instrumentation (Ulrich Prinz, “Bassoon," In Oxford Composer Companions: J. S. Bach, ed. Malcolm Boyd (Oxford: Oxford University Press, 1999), 59-60.). 


\begin{tabular}{|c|c|c|c|c|}
\hline & BWV 194 & BWV 165 & BWV 176 & BWV 129 \\
\hline Six movements & no & yes & yes & no \\
\hline Trumpets and timpani & no & no & no & yes \\
\hline Oboe da caccia & no & no & yes & no \\
\hline Oboe d'amore & no & no & no & yes \\
\hline Flauto traverso & no & no & no & yes \\
\hline Cantata in two parts & yes & no & no & no \\
\hline Twelve movements & yes & no & no & no \\
\hline Five movements & no & no & no & yes \\
\hline
\end{tabular}

\section{Performance/Compositional History}

In the Performance/Compositional History subsections of Chapters 2-5, attention was focused on the circumstances surrounding the first performances of the cantatas. Two of the cantatas were written originally for Leipzig Trinity Sunday presentations: BWV 176 and 129; BWV 165 was originally written for a Weimar Trinity Sunday performance. BWV 194 was first performed in Störmthal for a church/organ dedication service. This last cantata's music was based on an earlier secular cantata from Bach's time in service to the Prince of Anhalt-Cöthen (1717-1723). Some scholars theorize that the beginnings of the cantata extend even further back to a purely instrumental composition. The historical details of the cantatas are compared between each other in Table 6.3. The Jahrgang during which each cantata was first performed in Leipzig has also been indicated in the table. 
Table 6.3: Performance/Compositional History Comparison

\begin{tabular}{|c|c|c|c|c|}
\hline & BWV 194 & BWV 165 & BWV 176 & BWV 129 \\
\hline $\begin{array}{l}\text { First Leipzig } \\
\text { performance }\end{array}$ & $\begin{array}{l}\text { Trinity Sunday, } \\
\text { June 4, } 1724\end{array}$ & $\begin{array}{l}\text { Trinity Sunday, } \\
\text { June 4, } 1724\end{array}$ & $\begin{array}{l}\text { Trinity Sunday, } \\
\text { May 27, } 1725\end{array}$ & $\begin{array}{l}\text { Trinity Sunday, } \\
\text { June 16, } 1726 \\
\\
\text { (Reformation Sunday, } \\
\text { Oct. 31, } 1726 \text { - other } \\
\text { possible first } \\
\text { performance) }\end{array}$ \\
\hline $\begin{array}{l}\text { Jahrgang of } \\
\text { First Leipzig } \\
\text { performance }\end{array}$ & Jahrgang I & Jahrgang I & Jahrgang II & Jahrgang III \\
\hline $\begin{array}{l}\text { First } \\
\text { performance if } \\
\text { not Leipzig }\end{array}$ & $\begin{array}{l}\text { Church/organ } \\
\text { dedication, } \\
\text { Nov. 2, } 1723 \\
\text { Störmthal }\end{array}$ & $\begin{array}{l}\text { Trinity Sunday, } \\
\text { June 16, 1715, } \\
\text { Weimar }\end{array}$ & & \\
\hline $\begin{array}{l}\text { Other known } \\
\text { performances }\end{array}$ & $\begin{array}{l}\text { Parts of the cantata } \\
\text { performed as secular } \\
\text { cantata, } \\
1717-1723 \\
\text { (specific date } \\
\text { uncertain), } \\
\text { Cöthen } \\
\text { (BWV 194a) } \\
\text { Trinity Sunday, } \\
\text { June 16, 1726, } \\
\text { Leipzig } \\
\text { Trinity Sunday, } \\
\text { May 20, 1731 } \\
\text { Leipzig }\end{array}$ & $\begin{array}{l}\text { Trinity Sunday, } \\
\text { June } 7,1716 \\
\text { Weimar }\end{array}$ & & $\begin{array}{l}\text { Trinity Sunday, } \\
\text { June 8, } 1732\end{array}$ \\
\hline $\begin{array}{l}\text { Other } \\
\text { historical } \\
\text { details }\end{array}$ & $\begin{array}{l}\text { Only a few } \\
\text { instrumental parts are } \\
\text { extant from the 1717- } \\
1723 \text { Cöthen version. } \\
\text { No text has survived. } \\
\text { For the first Leipzig } \\
\text { performance, BWV } \\
194 \text { was paired with } \\
\text { BWV 165. BWV } 194 \\
\text { was performed before }\end{array}$ & $\begin{array}{l}\text { For the first Leipzig } \\
\text { performance, BWV } \\
165 \text { was paired with } \\
\text { BWV 194. BWV } 194 \\
\text { was performed before } \\
\text { the sermon; BWV } \\
165 \text { was performed } \\
\text { following the sermon. }\end{array}$ & $\begin{array}{l}\text { BWV } 176 \text { was one of } \\
\text { the final nine cantatas } \\
\text { of Jahrgang II, with } \\
\text { librettos by Christiane } \\
\text { Mariane von Ziegler. } \\
\text { The final fourteen } \\
\text { cantatas were the only } \\
\text { non-chorale cantatas } \\
\text { of Jahrgang II. }\end{array}$ & $\begin{array}{l}\text { As a chorale cantata, } \\
\text { BWV } 129 \text { was written } \\
\text { to take the place of } \\
\text { BWV } 176 \text { in the full- } \\
\text { chorale-cantata cycle } \\
\text { that was begun with } \\
\text { Jahrgang II. The full } \\
\text { chorale cantata cycle } \\
\text { was never completed. }\end{array}$ \\
\hline
\end{tabular}

${ }^{6}$ According to Dürr (The Cantatas of J. S. Bach: With Their Librettos in German-English Parallel Text) and Humphreys ("Gelobet sei der Herr, mein Gott"), the first performance of BWV 129 is uncertain; however, historians indicate Trinity Sunday, June 16, 1726, as the most probable first performance of the composition. 


\begin{tabular}{|c|c|c|c|}
\hline BWV 194 & BWV 165 & BWV 176 & $B W V 129$ \\
\hline $\begin{array}{l}\text { the sermon; BWV } \\
165 \text { was performed } \\
\text { following the sermon. } \\
\text { Some scholars } \\
\text { theorize that the } \\
\text { original material of } \\
\text { this cantata came } \\
\text { from a purely } \\
\text { instrumental } \\
\text { composition. }\end{array}$ & & & \\
\hline
\end{tabular}

\section{Libretto}

In the Libretto subsections of Chapters 2-5, attention was focused on the cantata's texts and the authors of the texts. For each of the four Trinity Sunday cantatas, librettos were written by different authors; however, the identity of only three of the librettists is known. Christiane Mariane von Ziegler was one of those three. The only known female librettist for Bach's cantatas, Ziegler supplied the librettos for the final nine cantatas of Jahrgang II. The librettist for BWV 165, Solomo Franck, was a regular collaborator with Bach. He and Bach collaborated on all but two of Bach's Weimar sacred cantatas. The libretto of BWV 129, by Johann Olearius, is taken from a single hymn by the author, with each of the five hymn verses serving as the texts for the five cantata movements. The chorale movement librettists for BWV 194, 165, and 176 were all well-known hymn writers in their day; especially Paul Gerhardt (BWV 194 and 176). Bach used Gerhardt's texts in over twenty-five of his cantatas and vocal works.

Three of the librettos were based on the scripture of the day for their original performances. The scripture readings of the day for the premiere of BWV 194 (a church/organ dedication service, Sunday, Nov. 2, 1723) were the Epistle reading, Revelation 21:2-8, and the Gospel reading, Luke 19:1-10. The scripture readings for the day of the premieres of BWV 165 
(Trinity Sunday, June 16, 1715) and 176 (Trinity Sunday, May 27, 1725) were the Epistle reading, Romans 11:33-36, and the Gospel reading, John 3:1-15. The readings for the day of the premiere of BWV 129 (Trinity Sunday, June 16, 1726) were also the Trinity Sunday scriptures (the Epistle reading, Romans 11:33-36, and the Gospel reading, John 3:1-15), but the cantata's libretto was not directly based on those texts. As stated previously, it was based on a hymn of praise to the Holy Trinity titled Gelobet sei der Herr by Johann Olearius. The locations in this document of the full text of the scripture readings and the Olearious hymn are found in the footnote below Table 6.4 .

The theological/philosophical foci of the cantatas are each different from the others, even though two of the cantatas were based on the same scripture, and they were all used for performances on Trinity Sunday. The focus of BWV 194 is to welcome God not only into the newly-built sanctuary for God's worship, but also to welcome God into the hearts of the church's congregation. The focus of BWV 165 is to encourage believers to walk in relationship with God throughout their lives, continually offering themselves up for cleansing through the power of Christ. The focus of BWV 176 is to remind God's people that even though they may long for the darkness (hiding their nature), they are encouraged, through faith and in relationship with Christ, to step into the light of wholeness and holiness. The focus of BWV 129 is a hymn of praise to the eternal triune God; the Father, Son, and Holy Spirit. The Details of the cantatas' librettos are compared in Table 6.4. 
Table 6.4: Libretto Comparison

\begin{tabular}{|c|c|c|c|c|}
\hline & BWV 194 & BWV 165 & BWV 176 & BWV 129 \\
\hline $\begin{array}{l}\text { Librettist of } \\
\text { non chorale } \\
\text { movements }\end{array}$ & Anonymous & Solomo Franck & $\begin{array}{l}\text { Christiane Mariane } \\
\text { von Ziegler }\end{array}$ & Johann Olearius \\
\hline $\begin{array}{l}\text { Librettist(s) } \\
\text { of chorale } \\
\text { movement(s) }\end{array}$ & $\begin{array}{l}\text { Johann Heermann and } \\
\text { Paul Gerhardt }\end{array}$ & Ludwig Helmbold & Paul Gerhardt & Johann Olearius \\
\hline $\begin{array}{l}\text { Main textual } \\
\text { source }\end{array}$ & $\begin{array}{l}\text { Scripture of the day } \\
\text { for the first } \\
\text { performance (a church } \\
\text { dedication service), } \\
\text { Revelations 21:2-8; } \\
\text { Luke 19:1-107 }\end{array}$ & $\begin{array}{l}\text { Gospel scripture of the } \\
\text { day for Trinity } \\
\text { Sunday, John 3:1-15 }\end{array}$ & $\begin{array}{l}\text { Gospel scripture of the } \\
\text { day for Trinity } \\
\text { Sunday, John 3:1-15 }\end{array}$ & $\begin{array}{l}\text { Gelobet sei der Herr, } \\
\text { a hymn written by } \\
\text { Olearius in praise of } \\
\text { the Holy Trinity }\end{array}$ \\
\hline $\begin{array}{l}\text { Cantata's } \\
\text { theological / } \\
\text { philosophical } \\
\text { focus }\end{array}$ & $\begin{array}{l}\text { Let us welcome God } \\
\text { not only into the } \\
\text { newly-built sanctuary } \\
\text { for God's worship, but } \\
\text { let us also welcome } \\
\text { God into our hearts. }\end{array}$ & $\begin{array}{l}\text { Let us walk in } \\
\text { relationship with God } \\
\text { throughout our lives, } \\
\text { continually offering } \\
\text { ourselves up for } \\
\text { cleansing through the } \\
\text { power of Christ. }\end{array}$ & $\begin{array}{l}\text { Even though we may } \\
\text { long for the darkness } \\
\text { (hiding our nature), let } \\
\text { us, through faith and } \\
\text { in relationship with } \\
\text { Christ, step into the } \\
\text { light of wholeness and } \\
\text { holiness. }\end{array}$ & $\begin{array}{l}\text { Let us praise God, } \\
\text { forever; the Father, } \\
\text { Son, and Holy Spirit. }\end{array}$ \\
\hline Other notes & $\begin{array}{l}\text { The focus of the text } \\
\text { is a church dedication; } \\
\text { however, the Holy } \\
\text { Trinity is mentioned } \\
\text { prominently in mvmts. } \\
6 \text { and 7, the last } \\
\text { movement of Part I } \\
\text { and the first } \\
\text { movement of Part II. }\end{array}$ & $\begin{array}{l}\text { Bach collaborated } \\
\text { with Franck on all but } \\
\text { two of his church } \\
\text { cantatas written in } \\
\text { Weimar. }\end{array}$ & $\begin{array}{l}\text { Bach collaborated } \\
\text { with Ziegler on the } \\
\text { final nine cantatas of } \\
\text { Jahrgang II. Ziegler } \\
\text { seemed to be } \\
\text { particularly focused } \\
\text { on the fact that } \\
\text { Nicodemus wanted to } \\
\text { meet Jesus at night. } \\
\text { Contrasts of night and } \\
\text { day are made } \\
\text { throughout the text. } \\
\text { Bach modified } \\
\text { Ziegler's text for use } \\
\text { in BWV 176. }\end{array}$ & $\begin{array}{l}\text { The text for the } \\
\text { cantata is taken word- } \\
\text { for-word from a hymn } \\
\text { by Olearius, without } \\
\text { paraphrase or } \\
\text { modification by Bach. }\end{array}$ \\
\hline
\end{tabular}

\footnotetext{
${ }^{7}$ For the full text of these scriptures, please see Chapter 2, subsection Libretto.

${ }^{8}$ For the full text of this scripture, please see Chapter 1, subsection Trinity Sunday and Scripture.

${ }^{9}$ For the full text of Olearius's libretto for BWV 129, please see Appendix: Text translations and Scriptural Allusions, subsection Gelobet sei der Herr, BWV 129.
} 


\section{Detail of Each Movement}

In the Detail of Each Movement subsections of Chapters 2-5, attention was focused on the cantatas' general compositional techniques and particular devices used to highlight the theological/spiritual aspects of the librettos. To bring out important text in the compositions, Bach used extended melismatic passages in both arias and recitatives, expressive arioso passages in recitative movements, uniquely higher notes than the surrounding pitches in recitatives, and duet passages between voices and between voice and instruments that contrasted different points of view. Dance-styles and dance-like motives were used throughout the cantatas to convey a sense of joy and to keep the momentum of the overall composition moving forward. Other compositional features in these cantatas were the dynamic use of trumpets in BWV 129; the colorful use of the oboe d'amore and the oboe da caccia in BWV 176 and 129; and the dramatic use of strings in the accompagnato recitative for bass in BWV 165.

Although trumpets play in both the first and final movements of BWV 129, in the last movement of the cantata, the trumpets drive the movement forward, through fanfares and polyphonic writing. The use of the oboe d'amore and oboe da caccia is particularly beautiful in BWV 176 and 129, when these sweet-toned instruments are paired with their vocal counterpart in tonal color, the alto soloist (BWV 176, mvmt. 5, oboe da caccia with two standard oboes, and the alto soloist; BWV 129, mvmt. 4, oboe d'amore with the alto soloist). In the only accompagnato recitative of the Trinity Sunday cantatas, the fourth movement of BWV 165, the strings parts are written very expressively, with melodic figures interspersed with sustained-note passages. At the end of the movement a particularly dramatic moment occurs in connection with the text wenn alle kraft vergehet (when all strength hath-vanished). After this text is sung by the 
bass soloist, the strings wind down to complete silence on the final measure, leaving only a single note (senza accompagnamento) in the basso continuo.

The compositional techniques found in the Trinity Sunday cantatas are summarized sideby-side in Table 6.5. Conclusions about these details and other features of the cantatas will be presented in Chapter 7. 


\section{Table 6.5: Detail of Each Movement Comparison}

\begin{tabular}{|c|c|c|c|c|}
\hline & BWV 194 & BWV 165 & BWV 176 & BWV 129 \\
\hline Mvmt. 1 & $\begin{array}{l}\text { B-flat major } \\
\text { Alla breve time } \\
\text { signature } \\
\text { Chorus for SATB } \\
\text { voices with tutti } \\
\text { instruments } \\
\text { French overture; one } \\
\text { of only six extant } \\
\text { cantatas that employ } \\
\text { the French overture } \\
\text { style; instruments are } \\
\text { alone in the beginning } \\
\text { slow section, fugal } \\
\text { choral section follows } \\
\text { with instruments } \\
\text { mainly doubling the } \\
\text { choral parts, slow } \\
\text { section ends the } \\
\text { movement mainly } \\
\text { played by instruments } \\
\text { with a brief choral } \\
\text { conclusion }\end{array}$ & $\begin{array}{l}\text { G major } \\
\text { Common time } \\
\text { signature } \\
\text { Aria for Soprano with } \\
\text { tutti instruments } \\
\text { Wholly polyphonic; } \\
\text { each instrumental } \\
\text { episode is a full fugal } \\
\text { exposition; key text is } \\
\text { brought out by } \\
\text { extended melismas }\end{array}$ & $\begin{array}{l}\text { C minor } \\
\text { Common time } \\
\text { signature } \\
\text { Chorus for SATB } \\
\text { voices with tutti } \\
\text { instruments } \\
\text { Grand choral } \\
\text { movement; four-part } \\
\text { choral fugue with } \\
\text { string fanfare parts } \\
\text { similar to } \\
\text { Brandenberg Concerto } \\
\text { No. 5; key text is } \\
\text { brought out by an } \\
\text { aurally descriptive } \\
\text { melodic line } \\
\text { representing the first } \\
\text { of many dualities } \\
\text { throughout the cantata }\end{array}$ & $\begin{array}{l}\text { D major } \\
\text { Common time } \\
\text { signature } \\
\text { Chorus for SATB, } \\
\text { with trumpets I-III, } \\
\text { timpani, flauto } \\
\text { traverso, oboes I-II, } \\
\text { strings, organ, and } \\
\text { basso continuo (tutti } \\
\text { instruments except for } \\
\text { oboe d'amore, whose } \\
\text { player also plays } \\
\text { Oboe II) } \\
\text { Grand choral } \\
\text { movement; bright and } \\
\text { festive concertato for } \\
\text { strings and } \\
\text { woodwinds with } \\
\text { trumpet/timpani } \\
\text { interjections; sopranos } \\
\text { sing cantus firmus } \\
\text { while other voices } \\
\text { join with imitative, } \\
\text { freely polyphonic, or } \\
\text { chordal substructure; } \\
\text { text praises God the } \\
\text { Father }\end{array}$ \\
\hline Mvmt. 2 & $\begin{array}{l}\text { B-flat major } \\
\text { Common time } \\
\text { signature } \\
\text { Recitative for bass } \\
\text { with basso continuo } \\
\text { Secco recitative; } \\
\text { textual highlighting } \\
\text { accomplished by use } \\
\text { of extra rests before } \\
\text { and throughout } \\
\text { important passages }\end{array}$ & $\begin{array}{l}\text { E minor - A minor } \\
\text { Common time } \\
\text { signature } \\
\text { Recitative for bass } \\
\text { with basso continuo } \\
\text { Secco recitative; } \\
\text { sections of the } \\
\text { recitative almost } \\
\text { become ariosos } \\
\text { because of the } \\
\text { expressive melodic } \\
\text { writing }\end{array}$ & $\begin{array}{l}\text { G minor } \\
\text { Common time } \\
\text { signature } \\
\text { Recitative for alto } \\
\text { with basso continuo } \\
\text { Brief secco recitative; } \\
\text { duality of night } \\
\text { (Nicodemus) and day } \\
\text { (Jesus) is presented }\end{array}$ & $\begin{array}{l}\text { A major } \\
\text { Three-eight time } \\
\text { signature } \\
\text { Aria for bass with } \\
\text { organ and basso } \\
\text { continuo } \\
\text { Intimate and personal; } \\
\text { text praises God the } \\
\text { Son; features basso } \\
\text { continuo part that } \\
\text { juxtaposes high/low } \\
\text { figures, symbolic of } \\
\text { God come down to } \\
\text { earth }\end{array}$ \\
\hline
\end{tabular}




\begin{tabular}{|c|c|c|c|c|}
\hline & BWV 194 & BWV 165 & BWV 176 & BWV 129 \\
\hline Mvmt. 3 & $\begin{array}{l}\text { B-flat major } \\
\text { Twelve-eight time } \\
\text { signature } \\
\text { Aria for bass with } \\
\text { oboe I, strings, and } \\
\text { basso continuo } \\
\text { Pastorale or siciliano; } \\
\text { textual highlighting } \\
\text { accomplished by } \\
\text { extended melismas on } \\
\text { key words }\end{array}$ & $\begin{array}{l}\text { E minor } \\
\text { Twelve-eight time } \\
\text { signature } \\
\text { Aria for alto with } \\
\text { basso continuo } \\
\text { Graceful slow gigue; } \\
\text { beautifully shaped } \\
\text { line of the basso } \\
\text { continuo; first musical } \\
\text { phrase rises } \\
\text { repeatedly by an } \\
\text { interval of a sixth; } \\
\text { voice picks up this } \\
\text { sixth pattern in the } \\
\text { first phrase; Bach uses } \\
\text { the graceful gigue to } \\
\text { bring out the freue } \\
\text { (rejoice) in the text }\end{array}$ & $\begin{array}{l}\text { B-flat major } \\
\text { Alla breve time } \\
\text { signature } \\
\text { Aria for soprano with } \\
\text { strings and basso } \\
\text { continuo } \\
\text { Da capo aria; gavotte- } \\
\text { like; night / day } \\
\text { duality imagery is } \\
\text { continued; constant } \\
\text { dance-like motive in } \\
\text { the violin I part } \\
\text { represents the } \\
\text { constant spirit of God, } \\
\text { only mimicked in the } \\
\text { voice on the text } \\
\text { Gottes Geist (God's } \\
\text { Spirit) and göttlich } \\
\text { auserlesen (divinely } \\
\text { chosen); long-held } \\
\text { note in the voice part } \\
\text { on the word ruhn } \\
\text { (rest) is paired with } \\
\text { the triplet Holy Spirit } \\
\text { motive in the violin I } \\
\text { part, depicting the } \\
\text { text, Gottes Geist muß } \\
\text { auf ihm ruhn (God's } \\
\text { Spirit must upon him } \\
\text { be-resting or God's } \\
\text { Spirit must be resting } \\
\text { upon him) }\end{array}$ & $\begin{array}{l}\text { C minor } \\
\text { Alla breve time } \\
\text { signature } \\
\text { Aria for soprano with } \\
\text { flauto traverso, violin } \\
\text { I solo, organ, and } \\
\text { basso continuo } \\
\text { Text praises God the } \\
\text { Spirit; driven by a } \\
\text { persistent sixteenth- } \\
\text { note motive that } \\
\text { suggests the Holy } \\
\text { Spirit as a flame, or a } \\
\text { "rushing mighty } \\
\text { wind" }\end{array}$ \\
\hline
\end{tabular}




\begin{tabular}{|c|c|c|c|c|}
\hline & BWV 194 & BWV 165 & BWV 176 & BWV 129 \\
\hline Mvmt. 4 & $\begin{array}{l}\text { G minor - E-flat major } \\
\text { Common time } \\
\text { signature } \\
\text { Recitative for soprano } \\
\text { with basso continuo } \\
\text { Secco recitative; very } \\
\text { brief melisma on a } \\
\text { key word }\end{array}$ & $\begin{array}{l}\text { B minor - G major } \\
\text { Common time } \\
\text { signature } \\
\text { Recitative for bass } \\
\text { with tutti instruments } \\
\text { Accompagnato } \\
\text { recitative; continually } \\
\text { varies between } \\
\text { speech-like sections } \\
\text { and arioso passages } \\
\text { (at an adagio tempo); } \\
\text { numerous vocal } \\
\text { melismas; arpeggiated } \\
\text { serpent motive in the } \\
\text { bass (representing the } \\
\text { first sin of Eden); very } \\
\text { expressive } \\
\text { instrumental writing } \\
\text { interspersed with } \\
\text { sustained-note } \\
\text { passages; after the } \\
\text { final text of the mvmt. } \\
\text { (wenn alle kraft } \\
\text { vergehet - "when all } \\
\text { strength hath- } \\
\text { vanished") the strings } \\
\text { wind down to a tacet } \\
\text { on the final measure, } \\
\text { leaving only the single } \\
\text { note (senza } \\
\text { accompagnamento) in } \\
\text { the basso continuo }\end{array}$ & $\begin{array}{l}\text { F major and G minor } \\
\text { Common and three- } \\
\text { four time signatures } \\
\text { Recitative for bass } \\
\text { with basso continuo } \\
\text { Secco recitative with } \\
\text { extended arioso } \\
\text { section to } \\
\text { accommodate text } \\
\text { added (most likely) by } \\
\text { Bach; extended } \\
\text { melisma with long- } \\
\text { held, and moving } \\
\text { notes to express key } \\
\text { text }\end{array}$ & $\begin{array}{l}\text { G major } \\
\text { Six-eight time } \\
\text { signature } \\
\text { Aria for alto with } \\
\text { oboe d'amore, organ, } \\
\text { and basso continuo } \\
\text { Pastoral, dance-like; } \\
\text { opening motive is } \\
\text { repeated in all } \\
\text { instruments and } \\
\text { voices, throughout the } \\
\text { movement; when the } \\
\text { three Persons of the } \\
\text { Trinity are featured, } \\
\text { music comes to an } \\
\text { octave-unison, splits } \\
\text { to three separate parts, } \\
\text { then joins again on a } \\
\text { octave- unison, with } \\
\text { notes in three different } \\
\text { octaves (symbolic of } \\
\text { the theology of the } \\
\text { Trinity: Three in One) }\end{array}$ \\
\hline
\end{tabular}




\begin{tabular}{|c|c|c|c|c|}
\hline & BWV 194 & BWV 165 & BWV 176 & BWV 129 \\
\hline Mvmt. 5 & $\begin{array}{l}\text { E-flat major } \\
\text { Alla breve time } \\
\text { signature } \\
\text { Aria for soprano with } \\
\text { strings and basso } \\
\text { continuo } \\
\text { Da capo aria; gavotte; } \\
\text { fire imagery depicted } \\
\text { in rising and falling } \\
\text { melodic lines; } \\
\text { sequential extended } \\
\text { melismas are } \\
\text { employed to feature } \\
\text { keys word }\end{array}$ & $\begin{array}{l}\text { G major } \\
\text { Common time } \\
\text { signature } \\
\text { Aria for tenor with } \\
\text { Violins 1/II (in } \\
\text { unison) and basso } \\
\text { continuo } \\
\text { Unison violins play a } \\
\text { twisting serpent } \\
\text { motive throughout } \\
\text { (serpent in this } \\
\text { movement is the } \\
\text { healing symbol of } \\
\text { Christ) }\end{array}$ & $\begin{array}{l}\text { E-flat major } \\
\text { Three-eight time } \\
\text { signature } \\
\text { Aria for alto with } \\
\text { oboes I/II, oboe da } \\
\text { caccia, and basso } \\
\text { continuo } \\
\text { In three contrasting } \\
\text { parts; oboes played in } \\
\text { unison during the } \\
\text { ritornello sections } \\
\text { representative of the } \\
\text { Holy Trinity; dance- } \\
\text { like; descriptive } \\
\text { melodic writing } \\
\text { depicts textual duality, } \\
\text { similar in shape to the } \\
\text { musical subject in } \\
\text { mvmt. } 1\end{array}$ & $\begin{array}{l}\text { D major } \\
\text { Common time } \\
\text { signature } \\
\text { Chorus for SATB } \\
\text { voices, with trumpets } \\
\text { I-III, timpani, flauto } \\
\text { traverso, oboes I-II, } \\
\text { strings, organ, and } \\
\text { basso continuo (tutti } \\
\text { instruments except for } \\
\text { oboe d'amore, whose } \\
\text { player also plays } \\
\text { Oboe II) } \\
\text { Brilliant movement; } \\
\text { opens with a fanfare; } \\
\text { trumpets play pivotal } \\
\text { role in driving the } \\
\text { movement, more than } \\
\text { just marking cadences } \\
\text { like in mvmt. 1; } \\
\text { chorus sings four-part } \\
\text { homophonic chorale } \\
\text { setting of the text with } \\
\text { instrumental episodes } \\
\text { of dynamic } \\
\text { polyphonic passages }\end{array}$ \\
\hline Mvmt. 6 & $\begin{array}{l}\text { B-flat major } \\
\text { Common time } \\
\text { signature } \\
\text { Chorale for SATB } \\
\text { with tutti instruments } \\
\text { End of Part I; chorale } \\
\text { with two stanzas; } \\
\text { plain chorale setting; } \\
\text { all instruments except } \\
\text { for oboe III double } \\
\text { voice parts (due to the } \\
\text { compass of the oboe } \\
\text { at that part's } \\
\text { tessitura); one of only } \\
\text { two movements in } \\
\text { which the Holy } \\
\text { Trinity was mentioned }\end{array}$ & $\begin{array}{l}\text { G major } \\
\text { Common time } \\
\text { signature } \\
\text { Chorale for SATB } \\
\text { with tutti instruments } \\
\text { Simple, peaceful } \\
\text { chorale setting }\end{array}$ & $\begin{array}{l}\text { F minor and C minor } \\
\text { Common time } \\
\text { signature } \\
\text { Choral for SATB with } \\
\text { tutti instruments } \\
\text { Four-part chorale } \\
\text { setting; harmonic key } \\
\text { transitions back to key } \\
\text { of cantata's first } \\
\text { mvmt. }\end{array}$ & \\
\hline
\end{tabular}




\begin{tabular}{|c|c|c|c|c|}
\hline & BWV 194 & BWV 165 & BWV 176 & BWV 129 \\
\hline Mvmt. 7 & $\begin{array}{l}\text { F major - C minor } \\
\text { Common time } \\
\text { signature } \\
\text { Recitative for tenor } \\
\text { with basso continuo } \\
\text { Beginning of Part II; } \\
\text { secco recitative; } \\
\text { extensive melismas on } \\
\text { key words; one of } \\
\text { only two movements } \\
\text { in which the Holy } \\
\text { Trinity is mentioned }\end{array}$ & & & \\
\hline Mvmt. 8 & $\begin{array}{l}\text { G minor } \\
\text { Common time } \\
\text { signature } \\
\text { Aria for tenor with } \\
\text { basso continuo } \\
\text { Da capo aria; gigue; } \\
\text { key words brought out } \\
\text { by melismas, } \\
\text { arpeggiation, and } \\
\text { large intervallic skips } \\
\text { to a high notes }\end{array}$ & & & \\
\hline
\end{tabular}




\begin{tabular}{|c|c|c|c|c|}
\hline & BWV 194 & BWV 165 & BWV 176 & BWV 129 \\
\hline Mvmt. 9 & $\begin{array}{l}\text { B-flat major - F major } \\
\text { Common time } \\
\text { signature } \\
\text { Recitative duet for } \\
\text { soprano and bass with } \\
\text { basso continuo } \\
\text { Secco recitative } \\
\text { ending with a brief } \\
\text { andante arioso } \\
\text { section; features a } \\
\text { duet from two points } \\
\text { of view (one of } \\
\text { Bach’s favorite } \\
\text { compositional } \\
\text { techniques) - doubt } \\
\text { and confirmation in } \\
\text { this movement; pitch } \\
\text { rises at the end of the } \\
\text { musical phrase with a } \\
\text { question and descends } \\
\text { at the end of musical } \\
\text { phrase with an } \\
\text { answer; when all the } \\
\text { questions are finally } \\
\text { answered the two } \\
\text { voices sing together in } \\
\text { an arioso section (the } \\
\text { only arioso section in } \\
\text { this cantata) }\end{array}$ & & & \\
\hline
\end{tabular}




\begin{tabular}{|c|c|c|c|c|}
\hline & BWV 194 & BWV 165 & BWV 176 & BWV 129 \\
\hline Mvmt. 10 & $\begin{array}{l}\text { F major } \\
\text { Three-four time } \\
\text { signature } \\
\text { Aria duet for soprano } \\
\text { and bass with oboes I } \\
\text { and II and basso } \\
\text { continuo } \\
\text { Da capo aria; minuet } \\
\text { with pastorale writing } \\
\text { for oboes; key word } \\
\text { emphasized by a long- } \\
\text { held vocal note, while } \\
\text { the other voice } \\
\text { continues } \\
\text { rhythmical/melodic } \\
\text { movement; the two } \\
\text { oboe parts extend this } \\
\text { pattern in their own } \\
\text { parts in the following } \\
\text { measures }\end{array}$ & & & \\
\hline Mvmt. 11 & $\begin{array}{l}\text { B-flat major } \\
\text { Common time } \\
\text { signature } \\
\text { Recitative for bass } \\
\text { with basso continuo } \\
\text { Secco recitative; } \\
\text { prepares for the final } \\
\text { chorale movement } \\
\text { with a "wake up” } \\
\text { word (wohlan - } \\
\text { "come-on") set on a } \\
\text { very high note; in the } \\
\text { final phrase of music, } \\
\text { Bach sets particular } \\
\text { words on uniquely } \\
\text { high notes to bring out } \\
\text { an inspired reading of } \\
\text { the text }\end{array}$ & & & \\
\hline
\end{tabular}




\begin{tabular}{|c|c|c|c|c|}
\hline & BWV 194 & BWV 165 & BWV 176 & BWV 129 \\
\hline Mvmt. 12 & $\begin{array}{l}\text { B-flat major } \\
\text { Three-four time } \\
\text { signature } \\
\text { Chorale for SATB } \\
\text { voices with tutti } \\
\text { instruments } \\
\text { Chorale with two } \\
\text { stanzas; plain chorale } \\
\text { setting; all } \\
\text { instruments except for } \\
\text { oboe III double voice } \\
\text { parts (due to the } \\
\text { compass of the oboe } \\
\text { at that part's } \\
\text { tessitura); like the last } \\
\text { phrase of the } \\
\text { preceding movement, } \\
\text { the key word (Herz - } \\
\text { "heart") is featured in } \\
\text { the chorale text }\end{array}$ & & & \\
\hline $\begin{array}{l}\text { Cantata's } \\
\text { significant } \\
\text { compositional } \\
\text { features and } \\
\text { other notes }\end{array}$ & $\begin{array}{l}\text { Bach uses vibrant } \\
\text { dance-like forms and } \\
\text { increasingly } \\
\text { expressive recitatives } \\
\text { and arias to move the } \\
\text { cantata forward } \\
\text { toward a heart-felt } \\
\text { climax at the end of } \\
\text { the cantata. } \\
\text { Some scholars } \\
\text { theorize that the } \\
\text { original material of } \\
\text { this cantata comes } \\
\text { from a purely } \\
\text { instrumental } \\
\text { composition. }\end{array}$ & $\begin{array}{l}\text { Two contrasting } \\
\text { serpent themes are } \\
\text { included in two } \\
\text { consecutive } \\
\text { movements. The first } \\
\text { serpent theme, in the } \\
\text { bass recitative, } \\
\text { represents the first sin; } \\
\text { the second theme, in } \\
\text { the following tenor } \\
\text { aria, represents the } \\
\text { healing Christ. }\end{array}$ & $\begin{array}{l}\text { An extended and very } \\
\text { expressive arioso } \\
\text { section sets a passage } \\
\text { of text, a paraphrase } \\
\text { the next verse } \\
\text { following the Gospel } \\
\text { reading for Trinity } \\
\text { Sunday, that was } \\
\text { added to the original } \\
\text { libretto (perhaps it } \\
\text { was added by Bach). } \\
\text { Three oboes played in } \\
\text { unison represent the } \\
\text { Holy Trinity in final } \\
\text { alto aria. }\end{array}$ & $\begin{array}{l}\text { BWV } 129 \text { is a } \\
\text { beautifully developed } \\
\text { cantata: brilliant outer } \\
\text { movements, with } \\
\text { highly expressive and } \\
\text { intimate inner } \\
\text { movements. The } \\
\text { movement form of the } \\
\text { cantata is spare; it } \\
\text { only has the } \\
\text { absolutely required } \\
\text { elements: one } \\
\text { movement for each of } \\
\text { the Persons of the } \\
\text { Holy Trinity, one } \\
\text { movement for all } \\
\text { three together, and a } \\
\text { final joyous } \\
\text { movement to bring it } \\
\text { all to a close (echoing } \\
\text { the dynamic quality of } \\
\text { the first movement). } \\
\text { There are no } \\
\text { recitatives in this } \\
\text { cantata. }\end{array}$ \\
\hline
\end{tabular}




\section{Chapter 7: Summary and Conclusions}

As presented in Chapter 1 of this document, this research project has focused on answering three questions about the Bach cantatas performed on Trinity Sunday in Leipzig: BWV 194, 165, 176, and 129. This chapter provides a summary of the answers that have been gleaned from the study of the four cantatas, as well as presents additional conclusions that have surfaced from the examination of the compositions.

\section{Question 1: From what musical and textual material did Bach compose his Trinity Sunday cantatas?}

For the librettos of his four cantatas, Bach drew upon four different authors: Solomo Franck, Johann Olearius, an anonymous author, and the only woman with whom he collaborated on his cantatas, Christiane Mariane von Ziegler. The librettos were based on scripture readings for Trinity Sunday, scripture readings for a church/organ dedication service, and a single hymn in praise of the Holy Trinity. The librettos for his chorale movements were written by wellknown authors of their day, all of whose texts were used by Bach in numerous other cantatas and vocal compositions: Johann Heerman, Paul Gerhardt, Ludwig Helmbold, and Johann Olearius.

Two of the cantatas were written specifically for the Leipzig liturgical celebrations of Trinity Sunday: BWV 176 and 129. One cantata was written originally for Trinity Sunday in Weimar: BWV 165. One cantata was based on a previous secular cantata from Bach’s time in service to the Prince of Anhalt-Cöthen: BWV 194. It is theorized that the origins of this last cantata may also extend back earlier in time than Cöthen, to a purely instrumental composition. Other details about each cantata's compositional history and musical style can be found in Chapters 2-5. 


\section{Question 2: How do the components and messages of the Trinity Sunday cantatas compare with one another?}

All of the Trinity Sunday cantatas begin and end with movements that feature all the instruments employed in each cantata. Each cantata ends with a chorale movement (named by Bach as either "choral” or “chorale”). Vocal soloists are used in every cantata: soprano and bass in all four, alto in three (BWV 165, 175, and 129), and tenor in two (BWV 194 and 165). All of the cantatas utilize wind instruments in addition to strings and basso continuo. Used in BWV 194, 176 and 129, oboes are the most common non-string instrument, and include the oboe da caccia in BWV 176, and the oboe d'amore in BWV 129.

Even though only two librettos were based on the same scripture, all four cantatas were composed and designated for Trinity Sunday and each presents a very different theological/spiritual message. BWV 194 is an exhortation for believers to welcome God not only into the newly-built sanctuary for God's worship, but into one’s heart. BWV 165 teaches the church's congregation about walking in relationship with God throughout life and continuing to offer themselves for cleansing through the power of Christ. Even though believers may long to hide their nature in the darkness, BWV 176 encourages the faithful to step into the light of wholeness and holiness through faith and in relationship with Christ. BWV 129 is a composition of praise offered to God; the Father, Son, and Holy Spirit. Other details of the cantatas’ comparisons can be found in Chapter 6. 


\section{Question 3: How did Bach use the musical and textual components of the cantatas to communicate his intended theological/philosophical messages?}

One of Bach’s primary ways of expressing messages was through melodic/rhythmic ideas and techniques employed on individual lines of text: long-held notes contrasted with continual moving lines in other parts, as on the word ruhn (rest) in BWV 176, mvmt. 3; extended melismatic passages, as on the word Freuden (joy) in BWV 194, mvmt. 8; and repeated motivic patterns, such as the triplet figure that appears in all parts of BWV 129, mvmt. 4. To affect the message of a cantata, Bach was not afraid to modify the librettist's text, even to the point of adding phrases, such as he did in BWV 176, mvmt. 4. By contrast, he also used the exact, unparaphrased text from a librettist, as he did with the hymn by Johann Olearius in BWV 129. This last practice, used throughout the first portion of Jahrgang II, gave his cantatas a strong sense of homogeneity.

Bach carefully arranged the style of each movement to reflect the composition's expressive intent, varying the intensity of the theological lessons with each movement. With dance-style aria movements, such as the gavotte, gigue, and minuet found in BWV 194, he interposed secco recitatives with speech-like patterns and recitatives that dissolved into expressive ariosos. He began his cantatas with tutti instruments in concertato style, such as in BWV 129, or as a French overture, such as in BWV 194. He ended these four cantatas consistently with a chorale that most likely was sung also by the congregations of his churches, which, in BWV 129 was accompanied in concertante style by the composition's orchestra. He varied the instrumentation from movement to movement, some with basso continuo alone, others with strings alone or with featured solo instruments, a technique found in all of his Trinity Sunday cantatas. 
He used the duality exemplified by a duet of voices or a duet between a solo voice and an instrument to depict different points of view, as in the recitative/aria duets between the soprano and bass soloists, BWV 194, mvmts. 9 and 10, and the aria for soprano with violin, BWV 176, mvmt. 3. Other ways that Bach used musical and textual components to communicate theological/spiritual messages can be found in the Detail subsections of Chapters 2-6.

\section{Additional Conclusions}

\section{Bach created only four Trinity Sunday cantatas for practical, creative, and theologically/spiritually expressive reasons.}

A practical man, Bach composed for the need at hand. Throughout his life, he wrote different genres of music to serve his current situation. During the years that he served as organist in Arnstadt, Mühlhausen, and Weimar, Bach wrote the majority of his organ works. At the court of Cöthen, where Bach served as Capellmeister, his compositional output was focused on secular music. Likewise, Bach wrote most of his cantatas during his first years serving as Cantor and Music Director in Leipzig. Once Bach had written five complete cycles of cantatas, as mentioned in his obituary, it is reasonable to assume that Bach felt that he had created the necessary musical resources to serve the needs for his Leipzig congregations. It has been made clear in this document that Bach repeated his cantatas' performances. With his 300 cantatas (60 cantatas for each of the five year cycles), Bach must have felt that he could rotate the cantatas to adequately serve his congregations.

In the later cycles of the liturgical year, Bach most likely interspersed within his own compositions works of other composers. It was unusual for a music director to only program compositions of his or her own hand, and Bach had at his disposal a library of sacred works by his Lutheran contemporaries and predecessors. It is reasonable to assume that, after the five 
cycles were completed, Bach may have begun to include other composers' works in his service planning, in addition to his own compositions.

One might assume that we simply do not know of all the Trinity Sunday cantatas, since only approximately 200 of the 300 original cantatas are extant; however, that theory seems improbable. Most likely, once Bach had written four cantatas for Trinity Sunday, he was finished with this feast day.

Bach was also a creative man, and creative individuals often tire of (re)creating in the same form or genre after a period of time. Once Bach had said what he needed to say through his Trinity Sunday cantatas, and through other multiples of cantatas that were composed for a single liturgical date, he likely felt he was finished with the genre of cantatas, and he decided to move on to other genres of music. Following the development of the four Trinity Sunday cantatas, it is clear that Bach finally had achieved his ideal Trinity Sunday cantata through the final cantata of the four, BWV 129.

It is possible that Bach never felt that the message of the Holy Trinity was properly conveyed in any of the previous Trinity Sunday cantatas before BWV 129. In its message, BWV 129 is a stark contrast to the other Trinity Sunday cantatas. It is a pure work of praise for the Three Persons of the Trinity: Father, Son, and Holy Spirit. The other Trinity Sunday cantatas have elements of darkness or somberness in them (BWV 165 and 176), or were originally intended for a church dedication (BWV 194). The bright BWV 129 contains no darkness or alternate purpose other than Praise for the Holy Trinity. Bach had finally communicated the ideal message of the Trinity in BWV 129, so he no longer needed to write any other cantatas for this liturgical day. 
Bach made choices about instrumentation based on availability of musicians and his intention of musical/theological expression. Instruments of the oboe family were the most prominently featured wind instruments of Bach's cantatas due to the excellent skills of Bach's Leipzig oboists.

Bach’s choices of instruments for his cantatas in Leipzig were limited, bound by the musicians that were available to him from the students at the St. Thomas School, the University of Leipzig, and the town musicians. Strings were always available, but the availability of winds varied. Even though his selection of instruments was restricted, Bach’s choices for the instrumentation of his cantatas seemed perfectly wed to the expressive intent of his compositions. Within the available roster of musicians, Bach was able to select the perfect combination of voices and instruments to convey the messages in his cantatas in the most beautiful manner. Within the span of the final three movements of BWV 129, three very different musical styles are presented to communicate three different messages of this Trinity Sunday cantata. For movement 3, focusing on the Holy Spirit, Bach selected the combination of soprano soloist, flute, violin, and basso continuo. No other combination of musicians could have as effectively conveyed the wind or breath of the Holy Spirit, than these light instruments presenting an ostinato sixteenth-note figure throughout the movement. In movement 4, the alto soloist, oboe d'amore, and basso continuo bring together all Three Persons of the Holy Trinity with a dance-like, pastoral composition in six-eight time. A brilliant contrast to the more intimate previous movements, the final, fifth movement of the cantata calls for all the musicians of the cantata to join in a grand song of praise to the Trinity with trumpet fanfares and flutes "singing with the angels," doubling the soprano voices at the octave above. Even with the constraints of the limited body of musicians available to him, Bach formed movements that perfectly express the text and theological/spiritual intent behind the text. 
In his choice of wind instruments for his cantatas, Bach seemed to favor the oboe family, most likely because he was able to work with two excellent oboists: Caspar Gleditsch and Gottfried Kornagel. Like Bach, Gleditsch, the first oboist, and Gottfried, the second oboist, were both employees of the city of Leipzig. It is clear from the amount of oboe repertoire (over twice as much as he created for any other instrument), the difficulty, and the expressiveness of that oboe repertoire that Bach highly favored and was inspired by these two musicians. ${ }^{1}$

Bach made use of the oboe family's rich palate of tonal colors in the parts he wrote for the oboe d'amore, the oboe da caccia, and the taille (not featured in the Trinity Sunday cantatas), in addition to the standard oboe. In the Trinity Sunday cantatas, Bach paired both the oboe d'amore and the oboe da caccia with alto soloists in dance-like movements that focused on the warm quality of sound in both the oboes and the voice, as in the alto aria featuring the oboe da caccia (in addition to two standard oboes in tutti passages), BWV 176, mvmt. 5, and in the alto aria featuring the oboe d'amore, BWV 129, mvmt. 4. In the 1710s, Leipzig was the site of the creation of both the oboe da caccia and the oboe d'amore. Gleditsch was closely connected to the development of these instruments. ${ }^{2}$

The oboe parts from his Trinity Sunday cantatas also featured the brilliant quality of the instrument, such as in the final movement of BWV 129, where the oboes I and II double most of the trumpet I and II parts. In other cantatas, Bach uses oboes for their flexibility in virtuosic passages and their power to bring out significant melodic figures. Within the rank of wind instruments available to Bach, he favored the oboe for the players with whom he was able to work, and expressed that favor by creating oboe music that exploited the instrument family's wide range of tonal color, power, and flexibility.

\footnotetext{
${ }^{1}$ Geoffrey Burgess and Bruce D. Haynes, The Oboe (New Haven, CT: Yale University Press, 2004), 72.

${ }^{2}$ Ibid.
} 


\section{Bach was an innovator.}

Many composers of the late $18^{\text {th }}$ Century viewed Bach as old-fashioned and behind-thetimes; however, an examination of Bach’s compositional practices reveals just the opposite. It is clear that Bach drew upon centuries-old musical techniques in his compositions, from his use of the cantus firmus practice to the utilization of modal melodies, both practices which appear in his cantata writing. In BWV 129, mvmt. 1, Bach sets a chorale tune in the soprano voice as a cantus firmus, while the lower voices and tutti instruments present polyphonic music that is imitative within those lower vocal and instrumental parts, but thematically distinct from the soprano cantus firmus. In the final movement of BWV 176, Bach sets a dorian mode melody with a fluid harmonization based in major/minor key areas.

Bach also drew upon the new techniques of his day, including the use of operatic style recitatives and da capo arias, as well as harmonic expansion into chromaticism, specifically at textually important moments in his chorale harmonizations. There are numerous examples of operatic recitative writing in three of the Trinity Sunday cantatas: BWV 194, 165, and 176. Within the Trinity Sunday cantatas, Bach presents da capo arias in the following movements: BWV 194, mvmts. 5, 8, and 10; and BWV 176, mvmt. 3. Bach sets a passage in the final chorale movement of BWV 194 with a chromatic chord sequence to convey the stages of the human journey through life's challenges. The determination of the specific technique, ancient or new, was dependent on Bach’s perception of the most effective way to convey each composition's message. 


\section{The Trinity Sunday cantatas reflect some of the most important features of the Jahrgänge during which they were first heard in Leipzig.}

When Bach arrived in Leipzig to pursue his work as Cantor and Music Director for the city, he decided to create cycles of cantatas for the entire church year (Jahrgänge) that were formed from his own compositions. Even though the first Jahrgang lacked compositional or textual unity, one characteristic stood out in the series of cantata: many of the cantatas presented in Leipzig as part of this cycle were revivals of previously composed works. Both BWV 194 and 165 fit this characteristic. BWV 194 was first performed in Störmthal as a church dedication cantata, seven months before its first presentation in Leipzig. This cantata was also based on a material from an even earlier, secular cantata dating from Bach's service as Capellmeister to the Prince of Anhalt-Cöthen (1717-1723). While the specific performance date of the original work is uncertain, BWV 165 was also a previously composed work. It was first performed on Trinity Sunday, June 16, 1715, in Weimar, where Bach served as concertmaster of the court cappelle.

For Bach’s second year in Leipzig (Jahrgang II), he attempted to create a unified cycle of chorale cantatas, whose texts were each based on or derived from hymns and whose musical material utilized the tunes associated with the hymns. The chorale cantatas ceased after the feast of the Annunciation in 1725, most likely due to the death of the cycle's librettist. The remaining cantatas in the cycle are non chorale cantatas, with the final nine based on librettos by Christiane Mariane von Ziegler. BWV 176 was part of the final nine cantatas of the cycle with a libretto by Ziegler. As part of the third cycle of cantatas, Jahrgang III, Bach composed several chorale cantatas that were intended to fill-in for the non chorale cantatas in Jahrgang II. Like Jahrgang I, Jahrgang III also lacked any unifying characteristic; however, the creation of fill-in chorale cantatas, such as BWV 129, stands out as the most significant common feature. Bach was never able to fully complete his chorale cantata cycle; however, with the creation of his final Trinity 
Sunday cantata, BWV 129, Bach must have felt that he had satisfactorily completed the series of cantatas for this liturgical day.

\section{The text and message were of prime importance in Bach's cantatas.}

Every element of Bach's cantatas was determined not only by the librettos of these works, but also by the messages that Bach chose to bring out through the musical setting of the librettos. The message of the libretto, as Bach saw it, determined the individual lines of musical expression in all of his cantatas. Examples of this type of expression are seen in the extended melismas composed for important words of the text. In the first movement of BWV 194, Bach extends the Freuden (joy) portion of the word Freudenfest (joy-feast) across several measures in all voice parts of the four-part chorus, through melismatic figures. In the first movement of BWV 165, Bach extends the word hochheiliges (most holy), as part of the phrase hochheiliges Gotteslamm (most holy Lamb of God), across several measures through melismas. Another example of expression, seen particularly in Bach's recitatives, is the practice of setting important words on higher notes than the notes for the surrounding text. In BWV 194, mvmt. 8, to highlight the word allein (alone) in the phrase Des Höchsten Gegenwart allein kann unsrer Freuden Ursprung sein (The Highest's presence alone can be the source of our joy), Bach set

high notes in the musical phrase that were reached from a sixth below. Bach's interest in textual expression extended to working with the librettos themselves. In BWV 176, Bach modified Ziegler's text, as well as added a full verse of scripture that was outside the parameter of the scripture for Trinity Sunday (John 3:16), in order to call attention to the message of salvation found through Christ. 
The importance of the text and message is clearly seen in Bach's use of hymns as one of the main unifying factors in Jahrgang II's cantatas. When he began this Jahrgang, each cantata was to be fully based on a hymn. Bach's librettos also contained multiple allusions of scriptural passages in addition to the scripture designated for Trinity Sunday or for the day on which the cantata was premiered. A table of scriptural allusions found in the Trinity Sunday cantatas is included in the Appendix of this document. The message was the key for Bach, as he tried to live out his faith through his musical works.

The writings of Martin Luther describe the musical arts as the "living voice of the Gospel.”3 In that light, and from the study of his Trinity Sunday cantatas, one can confidently acclaim J. S. Bach as an evangelist of the living, sacred art of music. It is this writer's hope that the explorations of this document will help others to see into Bach's art at a new depth, in these cantatas and in his works as a whole.

\footnotetext{
${ }^{3}$ Robin A. Leaver, “Johann Sebastian Bach: Theological Musician and Musical Theologian,” BACH: Journal of the Riemenschneider Bach Institute 31, no. 1 (January 2000): 20.
} 


\section{Appendix: Text translations and Scriptural Allusions}

\section{Höchsterwünschtes Freudenfest, BWV 194 \\ Much awaited joyful feast ${ }^{4}$}

Librettists: Unknown (mvmts. 1-5, 7-11), Johann Heermann (mvmt. 6), and Paul Gerhardt (mvmt. 12)

Scripture readings for the day of the first performance, the church and organ dedication in Störmthal, Nov 2, 1723:

Rev. 21:2-8 (The new Jerusalem comes down from heaven)

Lk. 19:1-10 (The conversion of Zacchaeus)

Scripture readings for the Sundays on which the cantata was revived and for which it was revised, Trinity Sundays, June 4, 1724; June 16, 1726; and May 20, 17315 :

Rom. 11:33-36 (O the depth of the riches and wisdom and knowledge of God!)

Jn. 3:1-15 (Discussion between Jesus and Nicodemus: You must be born anew)

Following is a table of the libretto translations, scriptural allusions, and the first lines of the scriptural passages (unless the full passages seem particularly significant for the cantata):

\begin{tabular}{|c|c|}
\hline Translation & Scripture \\
\hline $\begin{array}{l}\text { Part I } \\
1 \text { - Chorus [S, A, T, B] } \\
\text { Oboes I-III, Bassoon, Violins I/II, Viola, and Basso } \\
\text { Continuo } \\
\text { Church Dedication: A celebration of praise. } \\
\text { Höchsterwünschtes Freudenfest, } \\
\text { (O) most highly-desired festival-of-joy }{ }^{7} \text {, } \\
\text { Das der Herr zu seinem Ruhme } \\
\text { Which the Lord to his renown } \\
\text { Im erbauten Heiligtume } \\
\text { In (this newly) constructed sanctuary }\end{array}$ & $\begin{array}{l}1 \text { Kings 7:51-8:2, 65. All the work that King Solomon } \\
\text { did on the house of the Lord was finished. } \\
\text { Ps. 118:24. This is the day which the Lord has made; } \\
\text { let us rejoice and be glad in it. } \\
\text { Ps. 126:3. The Lord has done great things for us; we are } \\
\text { glad. }\end{array}$ \\
\hline \multicolumn{2}{|c|}{$\begin{array}{l}{ }^{4} \text { David Humphreys, "Höchsterwünschtes Freudenfest," in Oxford Composer Companions: J. S. Bach, ed. } \\
\text { a Boyd (Oxford: Oxford University Press, 1999), } 221 \\
5\end{array}$} \\
\hline
\end{tabular}


Uns vergnügt begehen läßt.

Us gladly celebrates lets.

(Let us gladly celebrate.)

Höchsterwünschtes Freudenfest!

(O) most highly-desired festival-of-joy!

2 - Recitative [Bass]

Basso Continuo

Prayer dedicating new sanctuary and our hearts to God.

Unendlich großer Gott, ach wende dich

(O) infinite great God, ah, turn

Zu uns, zu dem erwähleten Geschlechte,

To us, to (thy) chosen race,

Und zum Gebete deiner Knechte!

And to-the prayers of-thy servants!

Ach, laß vor dich

Ah, (Lord,) let before thee--

Durch ein inbrünstig Singen

Through - ardent singing-- ${ }^{9}$

(Ah Lord, through ardent singing, let before thee)

Der Lippen Opfer bringen!

(Our) lips’ offering be-brought!

Wir weihen unsre Brust dir offenbar

We dedicate our breast to-thee manifestly

(We manifestly dedicate our heart to thee)

Zum Dankaltar.

As (an) altar-of-thanksgiving.

Du, den kein Haus, kein Tempel faßt,

(O) thou, whom no house, no temple can-contain,

Da du kein Ziel noch Grenzen hast,

For thou no end nor limits hast--

(For thou art without end or limits--)

Laß dir dies Haus gefällig sein, es sei dein Angesicht

Let to-thee this house pleasing be,

(Let this house be pleasing to thee,)
1 Kings 8:22-23, 52-53. Then Solomon stood before the altar of the Lord in the presence of all the assembly of Israel and spread forth his hands toward heaven; and said, "O Lord, God of Israel, there is no God like thee.."

2 Chron. 5:1, 11, 13-14. Thus all the work that Solomon did for the house of the Lord was finished. Ps. 116:12. What shall I render to the Lord for all his bounty...?

Heb. 13:15. ...Let us continually offer up a sacrifice of praise to God, that is, the fruit of lips that acknowledge his name.

Ps. 50:14, 23. [God]: Offer to God a sacrifice of thanksgiving, and pay your vows to the Most High.

Rom. 12:1. ...Present your bodies as a living sacrifice, holy and acceptable to God, which is your spiritual worship.

2 Chron. 6:12-14, 18-20. Solomon stood before the altar of the Lord in the presence of all the assembly of Israel....and spread forth his hands toward heaven; and said, "O Lord, God of Israel, there is no God like thee, in heaven or on earth, keeping covenant and showing steadfast love to thy servants..."

Ex. 25:22. [God]: ...From above the mercy seat, from between the two cherubim that are upon the ark of the testimony [in my house], I will speak with you of all that I will give you in commandment for the people of Israel.

Ps. 89:15. Blessed are the people who know the festal shout, who walk, O Lord, in the light of thy countenance.

${ }^{9}$ Single short dashes in the translation surrounded by spaces (-) indicate that a word has not been included in the English version because its literal translation from the German would make no sense in the English (some articles, many reflexive pronouns, double negatives, etc.). 
es sei dein Angesicht

(may) it (become) for-thy countenance

Ein wahrer Gnadenstuhl, ein Freudenlicht.

A true mercyseat, a light-of-joy.

3 - Aria [Bass]

Oboe I, Violins I/II, Viola, and Basso Continuo

God's radiance fills the sanctuary he has chosen.

Was des Höchsten Glanz erfüllt,

What the Highest-One's radiance does-fill,

(Whatever the Highest One fills with his radiance,)

Wird in keine Nacht verhüllt,

Shall in no night be-veiled;

(Shall never be veiled in night;)

Was des Höchsten heilges Wesen

Whatever the Highest-One's holy nature

Sich zur Wohnung auserlesen,

For-himself as dwelling has-chosen,

(For his dwelling has chosen,)

Wird in keine Nacht verhüllt,

Will in no night be-veiled,

(Shall never be veiled in night;)

Was des Höchsten Glanz erfüllt.

Whatever the Highest-One's radiance does-fill.

(Whatever the Highest One fills with his radiance.)

4 - Recitative [Soprano]

Basso Continuo

Church Dedication: May God accept our offerings.

Wie könnte dir, du höchstes Angesicht,

How could to-thee, thou most-sublime countenance--

Da dein unendlich helles Licht

Since thy infinitely brilliant light

Bis in verborgne Gründe siehet,

- Into (the) hidden depths doth-see--

Ein Haus gefällig sein?

A house pleasing be?

(How could a house be pleasing to thee, $\mathrm{O}$ thou most sublime countenance, since thy infinitely brilliant light sees into all the hidden depths?)
Ps. 50:2. Out of Zion, the perfection of beauty, God shines forth.

$1 \mathrm{Jn} .1: 5$. God is light and in him is no darkness at all.

Jn. 1:4-5. In [Christ, the divine Word] was life, and the life was the light of men. The light shines in the darkness, and the darkness has not overcome it.

Heb. 1:3. [The Son] reflects the glory of God and bears the very stamp of his nature ...

1 Tim. 6:15-16. ... [He is] the King of kings and Lord of lords, who alone has immortality and dwells in unapproachable light, whom no man has ever seen or can see ...

Ex. 34:29-30, 33-35. When Moses came down from Mount Sinai, with the two tables of the testimony in his hand as he came down from the mountain, Moses did not know that the skin of his face shone because he had been talking with God.

2 Cor. 3:7-8. Now if the dispensation of death, carved in letters on stone, came with such splendor that the Israelites could not look at Moses' face because of its brightness, fading as this was, will not the dispensation of the spirit be attended with greater splendor?

2 Cor. 4:6. For it is the God who said, "Let light shine out of darkness," who has shone in our hearts to give the light of the knowledge of the glory of God in the face of Christ.

Rev. 21:2-3. I saw the holy city, new Jerusalem, coming down out of heaven from God, prepared as a bride adorned for her husband...

1 Kings 8:27. But will God indeed dwell on the earth?

1 Tim. 6:15-16. [He is] the blessed and only Sovereign, the King of kings and Lord of lords, who alone has immortality and dwells in unapproachable light...

Dan. 2:22. He reveals deep and mysterious things; he knows what is in the darkness, and the light dwells with him.

Ps. 139:11-12, 15. If I say, "Let only darkness cover me, and the light about me be night," even the darkness is not dark to thee, the night is bright as the day; for darkness is as light with thee...

Acts 7:48-50. The Most High does not dwell in houses made with hands; as the prophet says, "Heaven is my throne, and earth my footstool. What house will you build for me, says the Lord, or what is the place of my rest? Did not my hand make all these things?"

Ps. 8:3. [O Lord,] when I look at thy heavens, the work 
Es schleicht sich Eitelkeit allhie an allen Enden ein. (For) creeps-in - vanity here on every (side) - .

(For vanity doth creep in here on every side.)

Wo deine Herrlichkeit einziehet, Where'er thy glory takes-up-residence,

Da muß die Wohnung rein

There must be the dwelling clean

(There must the dwelling be clean)

Und dieses Gastes würdig sein.

And of-this guest worthy be.

(And worthy of this guest.)

Hier wirkt nichts Menschenkraft, Here avail nothing human-powers, (Here human powers avail nothing.)

Drum laß dein Auge offenstehen

Therefore let thine eye stand-open

Und gnädig auf uns gehen;

And graciously upon us (fall);

So legen wir in heilger Freude dir

Then lay we in holy joy for-thee

(Then we, in holy joy,)

Die Farren und die Opfer unsrer Lieder

(Our) bullocks and the offerings of-our songs

(Will lay down our bullocks and offerings of song)

Vor deinem Throne nieder

Before thy throne down

(Before thy throne)

Und tragen dir den Wunsch in Andacht für.

And bring-before thee (our) hope with devotion - .

5 - Aria [Soprano]

Violins I/II, Viola, and Basso Continuo

Prayer to be sanctified by Spirit as Isaiah was.

Hilf, Gott, daß es uns gelingt,

Help, (O) God, that this for-us (would) succeed, (Help, O God, that this would prove successful in us,)

Und dein Feuer in uns dringt,

And thy fire into us penetrate,

(That thy fire might penetrate into us,) of thy fingers... what is man that thou art mindful of him...?

Lk. 19:5-7. When Jesus came to the place [where Zacchaeus was in the sycamore tree], he looked up and said to him, "Zacchaeus, make haste and come down; for I must stay at your house today."

Is. 57:15. Thus says the high and lofty One who inhabits eternity, whose name is Holy: " 1 dwell in the high and holy place, and also with him who is of a contrite and humble spirit..."

1 Cor. 6:19-20. Do you not know that your body is a temple of the Holy Spirit within you, which you have from God? ...So glorify God in your body.

2 Chron. 6:18-20. [O Lord,] behold, heaven and the highest heaven cannot contain thee; how much less this house which I have built! Yet have regard to the prayer of thy servant ...that thy eyes may be open day and night toward this house ...

Hos. 14:2. Take with you words and return to the Lord; say to him "Take away all iniquity; accept that which is good and we will render the fruit of our lips."

Ps. 19:14. Let the words of my mouth and the meditation of my heart be acceptable in thy sight...
Is. 6:1-7. In the year that King Uzziah died I saw the Lord sitting upon a throne, high and lifted up; and his train filled the temple. Above him stood the seraphim; each had six wings: with two he covered his face, and with two he covered his feet, and with two he flew. And one called to another and said: "Holy, holy, holy is the Lord of hosts; the whole earth is full of his glory."

Lk. 3:16. John [said to the people], '1 baptize you with water; but he who is mightier than I is coming, the thong of whose sandals I am not worthy to untie; he will baptize you with the Holy Spirit and with fire." 
Daß es auch in dieser Stunde

That it (might) also in this hour,

Wie in Esaiae Munde

As (it did) in Isaiah's mouth,

Seiner Wirkung Kraft erhält

Its (effective) power retain

Und uns heilig vor dich stellt.

And us holy before thee bring.

(And bring us sanctified before thee.)

6 - Chorale [S, A, T, B]

Oboes I-III, Violins I/II, Viola, and Basso Continuo

Prayer: Holy Ghost, complete thy work of grace in me.

Verse 1

Heilger Geist ins Himmels Throne,

(O) Holy Ghost on heaven's throne,

Gleicher Gott von Ewigkeit

Equally God from (all) eternity

Mit dem Vater und dem Sohne,

With the Father and the Son,

(Coequal with the Father and the Son from all eternity,)

Der Betrübten Trost und Freud!

Of-the sorrowing (the) comfort and joy!

(Comfort and joy of all the sorrowing!)

Allen Glauben, den ich find ,

All-the faith, which I find (within me),

Hast du in mir angezündt,

Have thou in me kindled;

Über mir in Gnaden walte,

Over me in mercy hold-sway,

(Hold sway over me in mercy,)

Ferner deine Gnad erhalte.

Furthermore thy (favor) maintain.

(And maintain thy favor furthermore.)

Verse 2

Deine Hilfe zu mir sende,

Thy help to me send,

(Send thy help to me,)

Rom. 8:91. You are not in the flesh, you are in the Spirit, if in fact the Spirit of God dwells in you. Anyone who does not have the Spirit of Christ does not belong to him.

Epb. 5:18. ...Be filled with the Spirit.

Epb. 2:18. Through [Christ] we...have access in one Spirit to the Father.

Mt. 28: 19. ...in the name of the Father and of the Son and of the Holy Spirit.

Jn. 3:3, 5-6. Jesus [said], "...Truly, truly, I say to you, unless one is born of water and the Spirit, he cannot enter the kingdom of God. That which is born of the flesh is flesh, and that which is born of the Spirit is spirit.

Jn. 14:16-17. [Christ]: I will pray the Father, and he will give you another Counselor, to be with you forever, even the Spirit of truth...you know him, for he dwells with you, and will be in you.

Jn. 16:8. [Christ]: When [the Counselor] comes, he will convince the world concerning sin and righteousness and judgment.

1 Cor. 12:3. ...No one can say "Jesus is Lord" except by the Holy Spirit.

Rom. 8:14, 16. For all who are led by the Spirit of God are sons of God... lt is the Spirit himself bearing witness with our spirit that we are children of God.

1 Thess. 1:5-6. Our gospel came to you not only in word. but also in power and in the Holy Spirit and with full conviction... You received the word in much affliction, with joy inspired by the Holy Spirit

1 Cor. 2:12, 14. Now we have received not the spirit of the world, but the Spirit which is from God, that we might understand the gifts bestowed on us by God.

Heb. 6:4-5. ...[We] have tasted the heavenly gift, and have become partakers of the Holy Spirit, and have tasted the goodness of the word of God...

Ps. 103: 11. As the heavens are high above the earth, so great is [the Lord's] steadfast love toward those who fear him. 
O du edler Herzensgast!

$\mathrm{O}$ thou noble guest-of-(my)-heart!

Und das gute Werk vollende, And that good work complete, (And complete that good work,)

Das du angefangen hast.

Which thou begun hast.

(Which thou hast begun.)

Blas in mir das Fünklein auf, Blow in me that spark (alive), (Fan alive the flame,)

Bis daß nach vollbrachtem Lauf Till, after - completed course (Till, after my course is run)

Ich den Auserwählten gleiche

I the chosen-ones resemble

(I become like the chosen ones)

Und des Glaubens Ziel erreiche.

And - faith's goal attain.

(And attain the goal of my faith.)
Phil. 1:6. I am sure that he who began a good work in you will bring it to completion at the day of Jesus Christ.

Phil. 2:13. For God is at work in you, both to will and to work for his good pleasure.

Col. 1:27 ....Christ in you, the hope of glory.

Rev. 21:3. ...Behold, the dwelling of God is with men. He will dwell with them, and they shall be his people... Lk. 19:5-6. When Jesus came to the place [where Zacchaeus was in the sycamore tree], he looked up and said to him, "Zacchaeus, .make haste and come down; for I must stay at your house today.” So he made haste and came down and received him joyfully.

Jn. 20:22. ...[Jesus] said to [his disciples], "Receive the Holy Spirit."

Jn. 14:16-17. [Christ]: ...The Father...will [send] you another Counselor, to be with you forever, even the Spirit of truth... He dwells with you, and will be in you. Acts 2:1, 3-4. When the day of Pentecost had come, [the disciples] were all together in one place... And there appeared to them together as of fire, distributed and resting on each one of them. And they were all filled with the Holy Spirit...

1 Cor. 3:16. Do you not know that you are God's temple and that God's Spirit dwells in you?

Heb. 12:1-2. ...Let us run with perseverance the race that is set before us, looking to Jesus the pioneer and perfecter of our faith...

2 Tim. 4:7-8. I have fought the good fight, I have finished the race, I have kept the faith. Henceforth there is laid up for me the crown of righteousness, which the Lord, the righteous judge, will award to me on that Day, and not only to me but also to all who have loved his appearing.

Rev. 3:4. [Christ]: ...[The righteous] shall walk with me in white, for they are worthy.

Rev. 17:14. ... [Those who are with Christ] are called and chosen and faithful.

Phil. 3:14. I press on toward the goal for the prize of the upward call of God in Christ Jesus.

\section{Part II}

\section{7 - Recitative [Tenor]}

Basso Continuo

Rejoice, hasten to meet Trinity in his sanctuary!

Ihr Heiligen, erfreuet euch, Ye saints, rejoice,

Eilt, eilet, euren Gott zu loben:

Hasten, hasten, your God to praise:
Ps. 96:7-9/1 Chron. 16:28-30. Ascribe to the Lord, O families of the peoples, ascribe to the Lord glory and strength!

Ps. 122:1. I was glad when they said to me, "Let us go to the house of the Lord!"

Lam. 3:41. Let us lift up our hearts and hands to God in heaven.

Acts 7:48-50. The Most High does not dwell in houses made with hands; as the prophet says, "Heaven is my throne, and earth my footstool. What house will you build for me, says the Lord, or what is the place of my rest? Did not my hand make all these things?"

Acts 7:55-56. [Stephen), full of the Holy Spirit, gazed 
Das Herze sei erhoben

(Your) heart be lifted-up

(Lift up each heart)

$\mathrm{Zu}$ Gottes Ehrenreich,

To God's realm-of-glory,

Von dannen er auf dich,

From there he over thee,

(From there he watches over thee--)

Du heilge Wohnung, siehet

Thou holy dwelling, watches

(His holy dwelling--)

Und ein gereinigt Herz zu sich

And a purified heart to himself

(And draws every purified heart)

Von dieser eitlen Erde ziehet.

From this vain world draweth.

(Away from the world to himself.)

Ein Stand, so billig selig heißt,

A station, which rightly blest is-called,

(This station can rightly be called blessed,)

Man schaut hier Vater, Sohn und Geist.

(We) behold here Father, Son, and Spirit.

Wohlan, ihr gotterfüllte Seelen!

Well-then, ye divinely-filled souls!

Ihr werdet nun das beste Teil erwählen;

Ye will now the best part choose;

(Ye shall now choose the best part;)

Die Welt kann euch kein Labsal geben,

The world can ye no comfort give,

(The world can give ye no comfort,)

Ihr könnt in Gott allein vergnügt und selig leben.

Ye can in God alone content and blessed live.

(Only in God can ye live contentedly and blessedly.) into heaven and saw the glory of God, and Jesus standing at the right hand of God; and he said, "Behold, I see the heavens opened, and the Son of man standing at the right hand of God."

Col. 3:1-2. If then you have been raised with Christ, seek the things that are above, where Christ is, seated at the right hand of God. Set your minds on things that are above, not on things that are on earth.

Ps. 14:2. The Lord looks down from heaven upon the children of men, to see if there are any ...that seek after God.

1 Kings 8:28-29. [O Lord,] have regard to the prayer of thy servant...that thy eyes may be open night and day toward this house [that I have built] ...

1 Cor. 3:16-17. Do you not know that you are God's temple and that God's Spirit dwells in you? ...God's temple is holy, and that temple you are.

I Cor. 6:19-20. ... Your body is a temple of the Holy Spirit within you, which you have from God. You are not your own; you were bought with a price. So glorify God in your body.

Jms. 1:27. Religion that is pure and undefiled before God and the Father is this ...to keep oneself unstained from the world.

1 Jn. 2:15. Do not love the world or the things in the world. If anyone loves the world, love for the Father is not in him.

Jms. 4:4. ... Do you not know that friendship with the world is enmity with God? Therefore whoever wishes to be a friend of the world makes himself an enemy of God.

Jn. 6:44. [Christ]: No one can come to me unless the Father who sent me draws him.

Ps. 24:3-4. Who shall ascend the hill of the Lord? And who shall stand in his holy place? He who has clean hands and a pure heart...

Ps. 27:4. One thing have I asked of the Lord, that will I seek after; that I may dwell in the house of the Lord all the days of my life, to behold the beauty of the Lord, and to inquire in his temple.

Ps. 73:25-26. [O Lord,] whom have I in heaven but thee? And there is nothing upon earth that I desire besides thee. My flesh and my heart may fail, but God is the strength of my heart and my portion forever. Lk. 10:39-42. [Martha] had a sister called Mary, who sat at the Lord's feet and listened to his teaching. But Martha was distracted with much serving; and she went to him and said, "Lord, do you not care that my sister has left me to serve alone? Tell her then to help me." But the Lord answered her, "Martha, Martha, you are anxious and troubled about many things; one thing is needful. Mary has chosen the good portion, which shall not be taken away from her." 
Ps. 16:11. [O Lord,] thou dost show me the path of life; in thy presence there is fullness of joy, in thy right hand are pleasures forevermore.

8 - Aria [Tenor]

Basso Continuo

God's presence alone is source of our joy.

Des Höchsten Gegenwart allein

The Highest's presence alone

(Only the presence of the Most High)

Kann unsrer Freuden Ursprung sein.

Can our joy's (fountainhead) be.

(Can be the source of our joy.)

Vergehe, Welt, mit deiner Pracht, Vanish, (O) world, with thy pomp,

In Gott ist, was uns glücklich macht!

In God is, what us happy makes!

(In God we find that which makes us happy!)
Rev. 21:2-4. I saw the holy city, new Jerusalem, coming down out of heaven from God, prepared as a bride adorned for her husband; and I heard a loud voice from the throne saying, "Behold, the dwelling of God is with men. He will dwell with them, and they shall be his people, and God himself will be with them; he will wipe away every tear from their eyes, and death shall be no more, neither shall there be mourning nor crying nor pain any more, for the former things have passed away."

1 Jo. 2:15-17. Do not love the world or the things in the world. If anyone loves the world, love for the Father is not in him. For all that is in the world, the lust of the flesh and the lust of the eyes and the pride of life, is not of the Father but is of the world. And the world passes away, and the lust of it; but he who does the will of God abides forever.

Ps. 73:25. [O Lord,] whom have I in heaven but thee? And there is nothing upon earth that I desire besides thee.

\section{9 - Recitative (Duetto) [Bass, Soprano]}

Basso Continuo

Dialogue between Doubt and Confirmation.

Bass:

Kann wohl ein Mensch zu Gott im Himmel steigen?

Can indeed a mortal to God in heaven ascend?

(Can a mortal indeed ascend to God in heaven?)

Soprano:

Der Glaube kann den Schöpfer zu ihm neigen.

- Faith can the Creator (down) to itself (draw).

(Faith can draw the creator down.)

Bass:

Er ist oft ein zu schwaches Band.

It is oft a too weak bond.

(But fait is oft too weak a bond.)

\section{Soprano:}

Gott führet selbst und stärkt des Glaubens Hand, God leads himself and strengthens - faith's hand, (God himself leads and strengthens the hand of faith,)

Den Fürsatz zu erreichen.

(Its) purpose to achieve.
Rom. 10:6-11. The righteousness based on faith says, Do not say in your heart, "Who will ascend into heaven?" (that is, to bring Christ down) or "Who will descend into the abyss?" (that is, to bring Christ up from the dead). But what does it say? The word is near you, on your lips and in your heart (that is, the word of faith which we preach); because if you confess with your lips that Jesus is Lord and believe in your heart that God raised him from the dead, you will be saved. For man believes with his heart and so is justified, and he confesses with his lips and so is saved.

Jn. 3:12-13. [Christ]: If I have told you earthly things and you do not believe, how can you believe if I tell you heavenly things? No one has ascended into heaven but he who descended from heaven, the Son of man. Mk. 9:23-24. Jesus said to [the father of the sick child], "If you can: All things are possible to him who believes." Immediately the father of the child cried out and said, "I believe; help my unbelief!"

Phil. 2:13. God is at work in you, both to will and to work for his good pleasure.

1 Pet. 5:10. ...The God of all grace, who has called you to his eternal glory in Christ, will himself restore, establish, and strengthen you.

2 Thess. 1:11. To this end we always pray for you, that our God may make you worthy of his call, and may fulfill every good resolve and work of faith by his power.

Mk. 14:38. [Christ]: Watch and pray that you may not 
Bass:

Wie aber, wenn des Fleisches Schwachheit wollte weichen?

But-what, if the flesh's weakness would give-way?

Soprano:

Des Höchsten Kraft wird mächtig in den Schwachen.

The Highest's power (proves) mighty in the weak.

Bass:

Die Welt wird sie verlachen.

The world will them laugh-to-scorn.

(But the world will laugh them to scorn.)

Soprano:

Wer Gottes Huld besitzt, verachtet solchen Spott. Whoever god's favor possesses, disdains such scorn. (Whoever possesses God's favor disdains such scorn.)

Bass:

Was wird ihr außer diesen fehlen?

What will it besides this lack?

(Besides this, what else would faith's hand lack?)

\section{Soprano:}

Ihr einzger Wunsch, ihr alles ist in Gott.

Its sole wish, its all is (found) in God.

Bass:

Gott ist unsichtbar und entfernet:

God is invisible and distant:

(But God is invisible and distant:)

Soprano:

Wohl uns, daß unser Glaube lernet, Good-for us, that our faith learns,

(We are blessed if our faith learns,)

Im Geiste seinen Gott zu schauen.

In-the spirit its God to see.

(To see its God in the spirit.)

Bass:

Ihr Leib hält sie gefangen.

Its flesh holds it captive.

(But the hand of faith is held captive by the flesh.)

\section{Soprano:}

Des Höchsten Huld befördert ihr Verlangen,

The Highest's grace assists its desire,

(The grace of the Highest One assists its desire,) enter into temptation; the spirit indeed is willing, but the flesh is weak.

2 Cor. 12:9-10. [The Lord] said to me, "My grace is sufficient for you, for my power is made perfect in weakness."

Josh. 24:15. ...Choose this day whom you will serve ... Jms. 4:4. ..Do you not know that friendship with the world is enmity with God? Therefore whoever wishes to be a friend of the world makes himself an enemy of God.

Jn. 15:18-19. [Christ]: If the world hates you, know that it has hated me before it hated you. If you were of the world, the world would love its own; but because you are not of the world, but I chose you out of the world, therefore the world hates you.

Ps. 73:25. ... [O Lord,] there is nothing upon earth that I desire besides thee.

Ps. 27:4. One thing have I asked of the Lord, that will I seek after; that I may dwell in the house of the Lord all the days of my life, to behold the beauty of the Lord, and to inquire in his temple.

Ps. 95:3. The Lord is a great God, and a great King above all gods.

1 Tim. 6:15-16. ...[He is] the blessed and only Sovereign, the King of kings and Lord of lords, who alone has immortality and dwells in unapproachable light, whom no man has ever seen or can see...

Jn. 20:29. Jesus said to [Thomas]. "Have you believed because you have seen me? Blessed are those who have not seen and yet believe."

Mt.26:41. [Christ]: ...The spirit indeed is willing. but the flesh is weak.

Rom. 7:15, 18, 24-25. I do not understand my own actions. For I do not do what I want, but I do the very thing I hate ...For I know that nothing good dwells within me, that is, in my flesh. I can will what is right, but I cannot do it. Wretched man that I am! Who will deliver me from this body of death? Thanks be to God through Jesus Christ our Lord!...

Rom. 8:26. The Spirit helps us in our weakness... Jn. 14:1-3. [Christ]: Let not your hearts be troubled; believe in God, believe also in me. In my Father's house are many rooms; if it were not so, would I have told you that I go to prepare a place for you? And when I go and prepare a place for you, I will come again and will take you to myself, that where I am you may be also.

Ps. 84:4, 7. Blessed are those who dwell in thy house, ever singing thy praise!...The God of gods will be seen in Zion.

Ps. 26:8. O Lord, I love the habitation of thy house. and the place where thy glory dwells.

Heb. 11:6. ... [But] whoever would draw near to God must believe that he exists and that he rewards those who seek him. 
Denn er erbaut den Ort, da man ihn herrlich schaut. For he builds the place, where one him in-glory beholds.

(For he builds that place where we may behold him in his glory.)

Both:

Da er den Glauben nun belohnt

Since he - faith now rewards

Und bei uns wohnt,

And with us dwells--

Bei uns als seinen Kindern, With us as his (very) children--

So kann die Welt und Sterblichkeit

Thus can the world and (our) morality

die Freude nicht vermindern. (this) joy not diminish. (not diminish this joy.)
Jn. 1:12. To all who ...believed in [Christ's] name, he gave power to become children of God.

Eph. 3:17. ...Christ [will] dwell in your hearts through faith ...

1 Jn. 3:1-3. See what love the Father has given us, that we should be called children of God; and so we are.

The reason why the world does not know us is that it did not know him. Beloved, we are God's children now; it does not yet appear what we shall be, but we know that when he appears we shall be like him, for we shall see him as he is. And every one who thus hopes in him purifies himself as he is pure.

Jn. 3:6. [Christ]: That which is born of the flesh is flesh, and that which is born of the Spirit is spirit.

Rom. 8:9-11, 14-16. You are not in the flesh, you are in the Spirit, if in fact the Spirit of God dwells in you...
10 - Aria (Duetto) [Soprano, Bass]

Oboes I/II, Basso Continuo

God has chosen this as his house; how good for us!

O wie wohl ist uns geschehn, O how good (it) has for-us (turned-out), (O how we have been blessed.)

Daß sich Gott ein Haus ersehn!

That - God a house has-chosen!

Schmeckt und sehet doch zugleich,

(O) taste and see indeed together,

$(\mathrm{O}$, both taste and see, )

Gott sei freundlich gegen euch.

God is gracious to you.

(How gracious God is toward you.)

Schüttet eure Herzen aus

Pour your hearts out

(Pour out your hearts)

Hier vor Gottes Thron und Haus!

Here before God's throne and house!

11 - Recitative [Bass]

Basso Continuo

God dwells in this building as well as our hearts.
Ezra 3:10-11. When the builders laid the foundation of the temple of the Lord, the priests in their vestments came forward with trumpets, and the Levites, the sons of Asaph, with cymbals, to praise the Lord... and they sang responsively, praising and giving thanks to the Lord. "For he is good, for his steadfast love endures for ever toward Israel." And all the people shouted with a great shout, when they praised the Lord, because the foundation of the house of the Lord was laid.

Zero. 2:10. Sing and rejoice, O daughter of Zion; for lo, I come and I will dwell in the midst of you, says the Lord.

Ps. 46:7/11. The Lord of hosts is with us ...

Ps. 34:8. O taste and see that the Lord is good! Happy is the man who takes refuge in him!

Ps. 62:8. Trust in him at all times, O people; pour out your heart before him; God is a refuge for us.

Ezek. 43:4-7. As the glory of the Lord entered the temple by the gate facing east, the Spirit lifted me up, and brought me into the inner court; and behold. the glory of the Lord filled the temple. While the man was standing beside me, I heard one speaking to me out of the temple; and he said to me, "Son of man, this is the place of my throne ...where I will dwell in the midst of the people of Israel forever ..."

Lk. 19:5-6. When Jesus came to the place [where Zacchaeus was in the sycamore tree], he looked up and said to him, "Zacchaeus, make haste and come down; for I must stay at your house today." So he made haste 
Wohlan demnach, du heilige Gemeine, Come-on, (then), thou holy congregation,

Bereite dich zur heilgen Lust!

Prepare thyself for holy delight!

Gott wohnt nicht nur in einer jeden Brust,

God dwells not only in every individual breast,

Er baut sich hier ein Haus.

He (also) builds for-himself here a house.

(He also builds a house here for himself.)

Wohlan, so rüstet euch

Come-on, then (clothe) yourselves

mit Geist und Gaben aus, with (the) Spirit and (his) gifts - ,

Daß ihm so wohl dein Herz als auch dies Haus gefalle! That him (both) thine heart as well-as this house please! (That both thy heart and this house might be pleasing to him!)

12 - Chorale [S, A, T, B]

Oboes I-III, Violins I/II, Viola, Basso Continuo

Prayer that God accept our efforts and bless them.

Verse 1

Sprich Ja zu meinen Taten, Say "Yes" to my endeavors,

Hilf selbst das Beste raten;

Help, thyself, the best to-advise;

(Advise me thyself so I will choose the best part;)

Den Anfang, Mittl und Ende,

The beginning, middle, and end,

Ach, Herr, zum besten wende!

Ah Lord, to-the best turn!

(Ah Lord, make them all turn out for the best!)

Verse 2

Mit Segen mich beschütte,

With (thy poured-out) blessing me cover,

(Pour over me thy blessing,)

Mein Herz sei deine Hütte,

(May) my heart be thy shelter,

(May my heart be thy abode,) and came down and received him joyfully.

Rev. 21:3. ...Behold, the dwelling of God is with men. He will dwell with them, and they shall be his people, and God himself will be with them.

Zech. 2:10. Sing and rejoice, O daughter of Zion; for lo, I come and I will dwell in the midst of you, says the Lord.

Ps. 16:11....[O Lord], in thy presence there is fullness of joy, in thy right hand are pleasures forevermore.

Is. 57:15. Thus says the high and lofty One who inhabits eternity, whose name is Holy: "I dwell in the high and holy place, and also with him who is of a contrite and humble spirit!..."

Eph. 3:17, 19. ...Christ [will] dwell in your hearts through faith ...that you may be filled with all the fullness of God.

Eph. 5:18. ...Be filled with the Spirit

1 Cor. 12:11. All these [gifts] are inspired by one and the same Spirit, who apportions to each one individually as he wills.

2 Chron. 7:11-12. Thus Solomon finished the house of the Lord ...Then the Lord appeared to Solomon in the night and said to him: "I have heard your prayer, and have chosen this place for myself as a house of sacrifice."

Ps. 90:17. Let the favor of the Lord our God be upon us, and establish thou the work of our hands upon us, yea, the work of our hands establish thou it.

2 Cor. 1:18-20. As surely as God is faithful, our word to you has not been Yes and No. For the Son of God, Jesus Christ...was not Yes and No; but in him it is always Yes. For all the promises of God find their Yes in him. That is why we utter the Amen through him, to the glory of God.

Rom. 8:28. ...In everything God works for good with those who love him, who are called according to his purpose.

Jms. 1:5. If any of you lacks wisdom, let him ask God...and it will be given him.

Ps. 16:7. I bless the Lord who gives me counsel; in the night also my heart instructs me.

Gen. 32:26. ..1 will not let you go, unless you bless me. Deut. 26:15. [O Lord,] look down from thy holy habitation, from heaven, and bless thy people...

Ps. 28:9. O save thy people, and bless thy heritage; be thou their shepherd, and carry them forever.

1 Kings 8:57-58. [May] the Lord our God be with us, as he was with our fathers; may he not leave us or forsake us; that he may incline our hearts to him, to walk in all his ways, and to keep his commandments, his statutes, and his ordinances...

Eph. 3:17, 19. ...[May] Christ...dwell in your hearts 
Dein Wort sei meine Speise,

(May) thy Word be my food,

Bis ich gen Himmel reise!

Till I to heaven journey! through faith ...that you may be filled with all the fullness of God.

Col. 3:16. Let the word of Christ dwell in you richly... Mt. 4:4. [Christ]: ...Man shall not live by bread alone, but by every word that proceeds from the mouth of God.

1 Thess. 5:23. May the God of peace himself sanctify you wholly; and may your spirit and soul and body be kept sound and blameless at the coming of our Lord Jesus Christ. ${ }^{10}$

\section{O heilges Geist- und Wasserbad, BWV 165 $O$ holy bath of spirit and water ${ }^{11}$}

Librettists: Salomon Franck (mvmts. 1-5), and Ludwig Helmbold (mvmt. 6)

Scripture readings for the day of the first performance and successive revivals, Trinity Sundays, June 16, 1715; (June 7, 1716 likely); June 4, 1724 ${ }^{12}$ :

Rom. 11:33-36 (O the depth of the riches and wisdom and knowledge of God!) Jn. 3:1-15 (Discussion between Jesus and Nicodemus: You must be born anew)

Following is a table of the libretto translations, scriptural allusions, and the first lines of the scriptural passages (unless the full passages seem particularly significant for the cantata):

\begin{tabular}{|c|c|}
\hline Translation & Scripture \\
\hline $\begin{array}{l}1 \text { - Aria [Soprano] } \\
\text { Violins I/II, Viola, Bassoon, and Basso Continuo } \\
\text { Baptism by Spirit and water brings us into the kingdom. } \\
\text { O heilges Geist- und Wasserbad, } \\
\text { O sacred Spirit- and water-bath, } \\
\text { Das Gottes Reich uns einverleibet } \\
\text { Which God's kingdom for-us incorporates } \\
\text { (Which puts God's kingdom within us) } \\
\text { Und uns ins Buch des Lebens schreibet! } \\
\text { And us into-the book of life writes! } \\
\text { (And writes our names into the book of life!) }\end{array}$ & $\begin{array}{l}\text { Jn. 3:3, 5-6. Jesus answered [Nicodemus], 'Truly, truly, } \\
\text { I say to you, unless one is born anew, he cannot see the } \\
\text { kingdom of God...Truly, truly, I say to you, unless one } \\
\text { is born of water and the Spirit, he cannot enter the } \\
\text { kingdom of God. That which is born of the flesh is } \\
\text { flesh, and that which is born of the Spirit is spirit." } \\
\text { Lk. 3:16. John answered them all, "I baptize you with } \\
\text { water; but he who is mightier than I is coming, the } \\
\text { thong of whose sandals I am not worthy to untie; he } \\
\text { will baptize you with the Holy Spirit and with fire." } \\
\mathbf{1} \text { Pet. 3:21. Baptism, which corresponds to [Noah's } \\
\text { experience] now saves you, not as a removal of dirt } \\
\text { from the body but as an appeal to God for a clear } \\
\text { conscience, through the resurrection of Jesus Christ. } \\
\text { Gen. 7:11-12, 21-22, 23. In the six hundredth year of } \\
\text { Noah's life, in the second month, on the seventeenth day }\end{array}$ \\
\hline
\end{tabular}

${ }^{10}$ Unger, Handbook to Bach's Sacred Cantata Texts: An Interlinear Translation with Reference Guide to Biblical Quotations and Allusions, 674-683. All quoted or paraphrased elements of this cantata's appendix are from Unger unless otherwise marked.

${ }^{11}$ Johann Christian, "O heilges Geist- und Wasserbad," In Oxford Composer Companions: J. S. Bach, ed. Malcom Boyd (Oxford: Oxford University Press, 1999), 331.

12 Ibid. 
O Flut, die alle Missetat

O flood, which all iniquity

Durch ihre Wunder kraft ertränket

Through its miraculous-power drowns

(O flood which drowns all iniquity through its miraculous power)

Und uns das neue Leben schenket!

And on-us the new life bestows!

(And bestows the new life upon us!)

O heilges Geist- und Wasserbad!

O sacred Spirit- and water-bath! of the month, on that day all the fountains of the great deep burst forth, and the windows of the heavens were opened. And rain fell upon the earth forty days and forty nights... And all flesh died that moved upon the earth, birds, cattle, beasts, all swarming creatures that swarm upon the earth, and every man; everything on the dry land in whose nostrils was the breath of life died... only Noah was left, and those that were with him in the ark.

Rom. 6:4. We were buried therefore with [Christ] by baptism into death, so that as Christ was raised from the dead by the glory of the Father, we too might walk in newness of life.

2 Cor. 5:17. Therefore, if anyone is in Christ, he is a new creation; the old has passed away, behold, the new has come.

Col. 3:9-10 ... You have put off the old nature with its practices and have put on the new nature, which is being renewed in knowledge after the image of its creator.

Rev. 21:27. Nothing unclean shall enter [the heavenly city] ...only those who are written in the Lamb's book of life.

Lk. 10:20 [Christ]: Rejoice that your names are written in heaven.

2 - Recitative [Bass]

Basso Continuo

Baptism by water and Spirit heals us of sin’s disease

Die sündige Geburt verdammter Adamserben

The sin-begotten birth of-the-cursed heirs-of-Adam

(The sinful nature inherited at birth by the cursed heirs of Adam)

Gebieret Gottes Zorn, den Tod und das Verderben. Gives-birth-to God's wrath, - death, and - perdition. (Brings God's wrath, death, and perdition upon us.)

Denn was vom Fleisch geboren ist, For whatever of-the flesh born is, (For whatever is born of the flesh,)

Ist nichts als Fleisch, von Sunden angestecket, Is naught but flesh, by sin contaminated, (Is but fleshly, contaminated by sin,)

Vergiftet und beflecket.

Poisoned, and stained.

Wie selig ist ein Christ!

How blessed is a Christian!
Jn. 3:5-6 [Christ]: Truly, truly, I say to you, unless one is born of water and the Spirit, he cannot enter the kingdom of God. That which is born of the flesh is flesh, and that which is born of the Spirit is spirit.

Ps. 51:5. Behold, I was brought forth in iniquity, and in sin did my mother conceive me.

Rom. 7:18. I know that nothing good dwells within me, that is, in my flesh...

Rom. 5:12, 17-19. ...Sin came into the world through one man and death through sin, and so death spread to all men because all men sinned...Because of one man's trespass, death reigned through that one man...One man's trespass led to condemnation for all men...

Eph. 2:1-6. And you [God] made alive, when you were dead through the trespasses and sins in which you once walked, following the course of the world, following the prince of the power of the air, the spirit that is now at work in the sons of disobedience. Among these we all once lived in the passions of our flesh, following the desires of body and mind, and so we were by nature children of wrath like the rest of mankind. But God, who is rich in mercy, out of the great love with which he loved us, even when we were dead through our trespasses, made us alive together with Christ (by grace you have been saved), and raised us up with him, and made us sit with him in the heavenly places in Christ Jesus. 
Er wird im Geist- und Wasserbade

He becomes in-that Spirit- and water-bath

(In that Spirit- and water-bath)

Ein Kind der Seligkeit und Gnade.

A child of' heavenly-bliss and grace.

(He becomes a child of heavenly bliss and grace.)

Er ziehet Christum an

He puts Christ on

\{He clothes himself with Christ

Und seiner Unschuld weiße Seide,

And (with) his innocence's white silk,

(And with the white silk of Christ's innocence;)

Er wird mit Christi Blut, der Ehren Purpurkleide, He is with Christ's blood, of glory (the) purple-robe,

Im Taufbad angetan.

In baptism's-bath attired.

(In baptism's bath he is attired with Christ's blood, the purple robe of glory.)
1 Pet. 3:21. Baptism ...now saves you, not as a removal of dirt from the body but as an appeal to God for a clear conscience, through the resurrection of Jesus Christ.

Rom. 6:3-4. Do you not know that all of us who have been baptized into Christ Jesus were baptized into his death? We were buried therefore with him by baptism into death, so that as Christ was raised from the dead by the glory of the Father, we too might walk in newness of life.

Rom. 6:23. The wages of sin is death, but the free gift of God is eternal life in Christ Jesus our Lord.

1 Cor. 15:21-22, 47-49. As by a man came death, by a man has come also the resurrection of the dead. For as in Adam all die, so also in Christ shall all be made alive ...The first man was from the earth, a man of dust; the second man is from heaven. As was the man of dust, so are those who are of the dust; and as is the man of heaven, so are those who are of heaven. Just as we have borne the image of the man of dust, we shall also bear the image of the man of heaven.

Ezek. 16:9-10 [God): I bathed you with water ...I swathed you in fine linen and covered you with silk. Gal. 3:27. As many of you as were baptized into Christ have put on Christ.

Rev. 7:14. ... [The righteous] have washed their robes and made them white in the blood of the Lamb.

Eph. 2:4-6. God, who is rich in mercy, out of the great love with which he loved us, even when we were dead through our trespasses, made us alive together with Christ (by grace you have been saved), and raised us up with him, and made us sit with him in the heavenly places in Christ Jesus.

Mk. 16:16 [Christ]: He who believes and is baptized will be saved ...

Col. 2:12-14. And you were buried with him in baptism, in which you were also raised with him through faith in the working of God, who raised him from the dead. And you, who were dead in trespasses and the uncircumcision of your flesh, God made alive together with him, having forgiven us all our trespasses, having canceled the bond which stood against us with its legal demands; this he set aside, nailing it to the cross.

Rom. 6:4, 11-12. We were buried therefore with him by baptism into death, so that as Christ was raised from the dead by the glory of the Father, we too might walk in newness of life...So you also must consider yourselves dead to sin and alive to God in Christ Jesus. Let not sin therefore reign in your mortal bodies, to make you obey their passions.

Col. 3:1. If then you have been raised with Christ, seek the things that are above, where Christ is...

(Throughout) the whole (of my) life's-span. 
4 - Recitative [Bass]

Violins 1/II, Viola, Bassoon, and Basso Continuo

Baptismal vows are often broken, sanctification is needed

Ich habe ja, mein Seelenbräutigam,

I have, indeed, (O) my soul's-bridegroom--

Da du mich neu geboren,

When thou (didst-make) me newly born--

Dir ewig treu zu sein geschworen,

To-thee ever faithful to be sworn,

(l have indeed sworn ever to be faithful to thee, $\mathrm{O}$ my

soul's bridegroom, when thou didst give me new birth,)

Hochheilges Gotteslamm;

Most-holy Lamb-of-God;

Doch hab ich, ach! den Taufbund oft gebrochen

Yet have I, alas, the covenant-of-baptism often broken

(Yet, alas, I have often broken the covenant of baptism)

Und nicht erfüllt, was ich versprochen,

And not fulfilled, What I did-promise;

Erbarme, Jesu, dich

Have-mercy, (O) Jesus -,

Aus Gnaden über mich!

Out-of grace upon me!

(O Jesus, out of thy grace, have mercy upon me!)

Vergib mir die begangne Sünde,

Forgive me the committed sins,

Du weißt, mein Gott, wie schmerzlich ich empfinde

Thou knowest, (O) my God, how painfully I experience

Der alten Schlangen Stich;

The ancient serpent's sting;

Das Sündengift verderbt mir Leib und Seele,

The venom-of-sin corrupts (my) body and soul,

Hilf, daß ich gläubig dich erwähle,

Help, that I, believing, thee might-choose,

(Help that, in faith. I would choose thee,)

Blutrotes Schlangenbild,

(O) blood-red serpent-image,
1 Pet. 1:3. ...By [God's] great mercy we have been born anew to a living hope through the resurrection of Jesus Christ ...

Rom. 6:4. We were buried ...with him by baptism into death, so that as Christ was raised from the dead by the glory of the Father, we too might walk in newness of life.

Jn. 3:3 [Christ): ...Unless one is born anew, he cannot see the kingdom of God..

1 Jn. 4:10. In this is love, not that we loved God but that he loved us and sent his Son to be the expiation for our sins.

Jn. 1:29. ... [John] saw Jesus coming toward him, and said, "Behold, the Lamb of God, who takes away the sin of the world!"

Jer.31:3 [God): ...I have loved you with an everlasting love; therefore I have continued my faithfulness to you. Hos. 2:19 [God]: I will betroth you to me for ever ... Jer. 3:20. Surely, as a faithless wife leaves her husband, so have you been faithless to me, $\mathrm{O}$ house of Israel, says the -Lord.

Heb. 10:28-29. A man who has violated the law of Moses dies without mercy at the testimony of two or three witnesses. How much worse punishment do you think will be deserved by the man who has spurned the Son of God, and profaned the blood of the covenant by which he was sanctified, and outraged the Spirit of grace?

Rom. 6:2-3. ...How can we who died to sin still live in it? Do you not know that all of us who have been baptized into Christ Jesus were baptized into his death?

2 Cor. 11:2-3. I feel a divine jealousy for you, for I betrothed you to Christ to present you as a pure bride to her one husband. But I am afraid that as the serpent deceived Eve by his cunning, your thoughts will be led astray from a sincere and pure devotion to Christ.

Gen. 3:9, 11-13. [After Adam and Eve had eaten of the forbidden fruit in the garden of Eden], the Lord God called to the man, and said to him, "...Have you eaten of the tree of which I commanded you not to eat?" The man said, "The woman whom thou gavest to be with me, she gave me fruit of the tree and I ate." Then the Lord God said to the woman, "What is this that you have done?" The woman said, "The serpent beguiled me, and I ate."

Rom. 5:12, 19. Sin came into the world through one man and death through sin, and so death spread to all men... by one man's disobedience many were made sinners...

Gen. 6:5. The Lord saw that the wickedness of man was great in the earth, and that every imagination of the thoughts of his heart was only evil continually.

Ps. 14:2-3. The Lord looks down from heaven upon the children of men, to see if there are any that act wisely, 
Das an dem Kreuz erhöhet,

Which on the cross hath-been-raised,

Das alle Schmerzen stillt

Which all suffering doth-still

Und mich erquickt. wenn alle Kraft vergehet.

And me doth-revive, when all strength (hath-vanished).

5 - Aria [Tenor]

Violins I/II and Basso Continuo

Prayer: Sanctify me till death; You conquered death and $\sin$

Jesu, meines Todes Tod,

(O) Jesus, (who art) my death's death,

(O Jesus, thou who art the death of my death,)

Laß in meinem Leben

Let in my life

Und in meiner letzten Not

And (also) in my last (hour's) need

Mir vor Augen schweben,

Before-mine eyes (this thought) hover,

Daß du mein Heilschlänglein seist

That thou my serpent-of-Salvation art that seek after God. They have all gone astray, they are all alike corrupt; there is none that does good, no, not one.

Rom. 7:15, 19-20. I do not understand my own actions ...For I do not do the good I want, but the evil I do not want is what I do. Now if I do what I do not want, it is no longer I that do it, but sin which dwells within me ... Lk. 18:13. ...God be merciful to me a sinner!

Num. 21:5-9. The people [of Israel] spoke against God and against Moses, "Why have you brought us up out of Egypt to die in the wilderness? For there is no food and no water, and we loathe this worthless food." Then the Lord sent fiery serpents among the people, and they bit the people, so that many people of Israel died. And the people came to Moses, and said, "We have sinned, for we have spoken against the Lord and against you; pray to the Lord, that he take away the serpents from us." So Moses prayed for the people. And the Lord said to Moses, "Make a fiery serpent, and set it on a pole; and everyone who is bitten, when he sees it, shall live." So Moses made a bronze serpent, and set it on a pole; and if a serpent bit any man, he would look at the bronze serpent and live.

Jn. 3:14-15. As Moses lifted up the serpent in the wilderness, so must the Son of man be lifted up, that whoever believes in him may have eternal life.

Heb. 12:1-2. .... Let us also lay aside every weight, and sin which clings so closely, and let us run with perseverance the race that is set before us, looking to Jesus the pioneer and perfecter of our faith, who for the joy that was set before him endured the cross...

Is. 25:8. He will swallow up death forever, and the Lord God will wipe away tears from all faces...

2 Tim. 2:10. ...through the appearing of our Savior Christ Jesus, who abolished death and brought life and immortality to light...

Heb. 2:14-15. Since therefore the children share in flesh and blood, [Christ] himself likewise partook of the same nature, that through death he might destroy him who has the power of death, that is, the devil, and deliver all those who through fear of death were subject to lifelong bondage.

1 Jn. 3:8. ... The reason the Son of God appeared was to destroy the works of the devil.

Heb. 9:26. [Christ] appeared... to put away sin by the sacrifice of himself.

1 Jn. 3:5. You know that he appeared to take away sins, and in him there is no sin.

Num. 21:9. Moses made a bronze serpent, and set it on a pole; and if a serpent bit any man, he would look at the bronze serpent and live.

Jn. 3:14-15. As Moses lifted up the serpent in the wilderness, so must the Son of man be lifted up, that 
Für das Gift der Sunde.

For the poison of sin.

Heile, Jesu, Seel und Geist,

Heal, (O) Jesus, (my) soul and spirit,

Daß ich Leben finde!

That I life might-find!

6 - Chorale [S, A, T, B]

Violins I/II, Viola, Bassoon, and Basso Continuo

Baptism, Word, and Eucharist guard us from evil

Sein Wort. sein Tauf, sein Nachtmahl

His Word, his baptism, his supper

Dient wider allen Unfall.

Serves to-counter all calamity;

Der Heilge Geist im Glauben

The Holy Ghost in faith

(Through our faith the Holy Ghost)

Lehrt uns darauf vertrauen.

Teaches us in-this to-trust.

(Teaches us to believe this.) whoever believes in him might have eternal life.

Heb. 13:12. Jesus also suffered outside the gate in order to sanctify the people through his own blood.

1 Thess. 5:23. May...God...sanctify you wholly; and may your spirit and soul and body be kept sound and blameless at the coming of our Lord Jesus Christ.

Jms. 1:21. ...The implanted word ...is able to save your souls.

Mt.7:24-25 [Christ]: Everyone then who hears these words of mine and does them will be like a wise man who built his house upon the rock; and the rain fell, and the floods came, and the winds blew and beat upon that house, but it did not fall, because it had been founded on the rock.

1 Pet. 3:21. Baptism ...now saves you, not as a removal of dirt from the body but as an appeal to God for a clear conscience, through the resurrection of Jesus Christ.

1 Cor. 10:16. The cup of blessing which we bless, is it not a participation in the blood of Christ? The bread which we break, is it not a participation in the body of Christ?

Jn. 6:54,56 [Christ]: He who eats my flesh and drinks my blood has eternal life ... He who eats my flesh and drinks my blood abides in me, and I in him.

Jn. 14:26-27 [Christ]: The Counselor, the Holy Spirit, whom the Father will send in my name, he will teach you all things...

1 Cor. 2:12-14. Now we have received not the spirit of the world, but the Spirit which is from God, that we might understand the gifts bestowed on us by God. And we impart this in words not taught by human wisdom but taught by the Spirit, interpreting spiritual truths to those who possess the Spirit. The unspiritual man does not receive the gifts of the Spirit of God, for they are folly to him, and he is not able to understand them because they are spiritually discerned. ${ }^{13}$

${ }^{13}$ Unger, Handbook to Bach's Sacred Cantata Texts: An Interlinear Translation with Reference Guide to Biblical Quotations and Allusions, 569-573. All quoted or paraphrased elements of this cantata's appendix are from Unger unless otherwise marked. 


\title{
Es ist ein trotzig un verzagt Ding, BWV 176 The heart is deceitful above all things ${ }^{14}$
}

\author{
Librettist: Christiane Mariane von Ziegler (modified)
}

Scripture readings for the day of the first performance, Trinity Sunday, May 27, $1725^{15}$ : Rom. 11:33-36 (O the depth of the riches and wisdom and knowledge of God!) Jn. 3:1-15 (Discussion between Jesus and Nicodemus: You must be born anew)

Following is a table of the libretto translations, scriptural allusions, and the first lines of the scriptural passages (unless the full passages seem particularly significant for the cantata):

\begin{tabular}{l|l} 
Translation & Scripture \\
\hline $\begin{array}{l}\text { 1 - Chorus [S, A, T, B] } \\
\text { Oboes I/II, Oboe da caccia, Violins I/II, Viola, and } \\
\text { Basso Continuo }\end{array}$ & $\begin{array}{l}\text { Jer. 17:9-10. The heart is deceitful above all things, } \\
\text { and desperately corrupt; who can understand it? "I the } \\
\text { Lord search the mind and try the heart, to give to every } \\
\text { man according to his ways, according to the fruit of his } \\
\text { doings." } \\
\text { Prov. 20:9. Who can say, "I have made my heart clean; } \\
\text { I am pure from my sin"? } \\
\text { Jn.2:25. [Jesus] knew all men and needed no one to } \\
\text { bear witness of man; for he himself knew what was in } \\
\text { man. }\end{array}$ \\
$\begin{array}{l}\text { Es ist ein trotzig und verzagt Ding } \\
\text { It is an obstinate and disheartening thing }\end{array}$ & \\
$\begin{array}{l}\text { um aller Menschen Herze. } \\
\text { about all human hearts. } \\
\text { (about the human heart.) }\end{array}$ &
\end{tabular}

2 - Recitative [Alto]
Basso Continuo

Timid Nicodemus, unlike Joshua, prefers night

Ich meine, recht verzagt,

I think (it was) truly faint-hearted (of him),

[verzagt $=$ disheartened but also faint-hearted]

Daß Nikodemus sich bei Tage nicht,

That Nicodemus - by day not (but)

Bei Nacht zu Jesus wagt.

By night to Jesus did-venture.

(That Nicodemus would not venture to visit Jesus by day but only by night.)
Jn. 3:1-3. Now there was a man of the Pharisees, named Nicodemus, a ruler of the Jews. This man came to Jesus by night and said to him, "Rabbi, we know that you are a teacher come from God; for no one can do these signs that you do, un1ess God is with him." Jn. 19:38-39. ... [After Jesus' crucifixion] Joseph of Arimathea, who was a disciple of Jesus, but secretly, for fear of the Jews, asked Pilate that he might take away the body of Jesus, and Pilate gave him leave. So he came and took away his body. Nicodemus also, who had at first come to him by night, came bringing a mixture of myrrh and aloes, about a hundred pounds' weight.

Jn. 7:13. For fear of the Jews no one spoke openly of [Jesus].

Jn. 12:42. Many even of the authorities believed in [Jesus], but for fear of the Pharisees they did not confess it...

2 Tim. 1:8. Do not be ashamed... of testifying to our Lord ...

\footnotetext{
${ }^{14}$ David Schulenberg, "Es ist ein trotzig un verzagt Ding" In Oxford Composer Companions: J. S. Bach,
} ed. Malcom Boyd (Oxford: Oxford University Press, 1999), 163.

${ }^{15}$ Ibid. 
Die Sonne mußte dort bei Josua so lange stille stehn, The sun was-forced - with Joshua so long still to-stand, (In Joshua's day the sun was forced to stand still so long.)

So lange bis der Sieg vollkommen war geschehn; So long till the victory fully had-been accomplished; (Until the victory had been fully accomplished;)

Hier aber Wünschet Nikodem:

Here however wishes Nicodemus:

O säh ich sie zu Ruste gehn!

O saw I it to rest go!

(But here Nicodemus wishes: $\mathrm{O}$ that the sun would go to rest!)

3 - Aria [Soprano]

Violins I/II, Viola, and Basso Continuo

Fear keeps me from seeking omnipotent God by day

Dein sonst hell beliebter Schein

Thy normally bright beloved radiance

(Thy beloved radiance, normally so bright,)

Soll für mich umnebelt sein,

Must for me beclouded be,

[Nebel $=$ fog $]$

Weil ich nach dem Meister frage, While I for the master ask,

(While I seek the master,)

Denn ich scheue mich bei Tage.

For I am-fearful by day.

Niemand kann die Wunder tun,

No-one can these wonders do,

(No human could do such wonders,)

Denn sein Allmacht und sein Wesen.

For his omnipotence, and his nature,

(For his almighty power, and his nature,)

Scheint, ist göttlich auserlesen,

It-would-seem, are divinely chosen,

Gottes Geist muß auf ihm ruhn.

God's Spirit must upon him be-resting.

(God's Spirit must be resting upon him.)
1 Thess. 5:4-5, 8. You are not in darkness, brethren... For you are all sons of light and sons of the day; we are not of the night or of darkness... we belong to the day... Josh. 10:12-14. ...Joshua [spoke] to the Lord in the day when the Lord gave the Amorites over to the men of Israel; and he said in the sight of Israel, "Sun, stand thou still at Gibeon, and thou Moon in the valley of Aijalon." And the sun stood still, and the moon stayed, until the nation took vengeance on their enemies... The sun stayed in the midst of heaven, and did not hasten to go down for about a whole day. There has been no day like it before or since, when the Lord hearkened to the voice of a man: for the Lord fought for Israel.

2 Cor. 4:3-4, 6. Even if our gospel is veiled, it is veiled only to those who are perishing. In their case the god of this world has blinded the minds of the unbelievers, to keep them from seeing the light of the gospel of the glory of Christ, who is the likeness of God...For it is the God who said, "Let light shine out of darkness," who has shone in our hearts to give the light of the knowledge of the glory of God in the face of Christ. 1 Thess. 5:5-8. For you are all sons of light and sons of the day; we are not of the night or of darkness. So then let us not sleep, as others do, but let us keep awake and be sober. For those who sleep at night, and those who get drunk are drunk at night. But, since we belong to the day, let us be sober, and put on the breastplate of faith and love, and for a helmet the hope of salvation.

Mt.10:32-33 [Christ]: Everyone who acknowledges me before men, I also will acknowledge before my Father who is in heaven; but whoever denies me before men, I also will deny before my Father who is in heaven.

2 Tim. 2:12. If we endure, we shall also reign with him; if we deny him, he also will deny us.

Jn. 3:1-3. Now there was a man of the Pharisees, named Nicodemus, a ruler of the Jews. This man came to Jesus by night and said to him, "Rabbi, we know that you are a teacher come from God; for no one can do these signs that you do, unless God is with him."

Jn. 2:23. ...Many believed in [Jesus'] name when they saw the signs which he did.

Jn. 20:30-31. Now Jesus did many other signs in the presence of the disciples, which are not written in this book; but these are written that you may believe that Jesus is the Christ, the Son of God, and that believing you may have life in his name. 
4 - Recitative [Bass]

Basso Continuo

Fear keeps me from seeking God openly; yet I believe

So wundre dich, O Meister, nicht,

So wonder -, O master, not

(So do not wonder, O master,)

Warum ich dich bei Nacht ausfrage!

Why I thee by night do-seek!

(Why I seek thee by night!)

Ich fürhte, daß bei Tage

I fear, that by day

Mein Ohnmacht nicht bestehen kann.

My powerlessness (will) not to-stand-the-test be-able.

(My powerlessness will not be able to stand the test.)

Doch tröst ich mich,

Yet comfort I myself,

(Yet I comfort myself that)

du nimmst mein Herz und Geist

thou dost-admit-and-accept my heart and spirit

Zum Leben auf und an,

Unto life - - -,

[aufnehmen $=$ to admit, annehmen = to accept $]$

Weil alle, die nur an dich glauben, nicht verloren werden.

For all, who just in thee believe, not lost shall-be. (For all who will just believe in thee, shall not perish.)

5 - Aria [Alto]

Oboes I/II, Oboe da caccia, and Basso Continuo

Courage! God promises eternal life by faith

Emuntert euch, furchtsam und schüchterne Sinne, Rouse yourselves, (O) fearful and timid faculties,

Erholet euch, höret. was Jesus verspricht:

Be-renewed; hear, what Jesus promises:

Daß ich durch den Glauben den Himmel gewinne.

That I through - faith heaven obtain.

(That I shall obtain heaven by faith.)

Wenn die Verheißung erfüllend geschicht. When the promise (fulfillment) (achieves), (When the promise is finally fulfilled,)
Jn. 3:1-2. ..Nicodemus, a ruler of the Jews ...came to Jesus by night...

Jn. 20:19. On the evening of [the first day after Christ's resurrection]... the doors being shut where the disciples were, for fear of the Jews.

Mt.26:41 [Christ]: ...The spirit indeed is willing, but the flesh is weak.

Rom. 7:15, 18-20, 24-25. I do not understand my own actions. For I do not do what I want, but I do the very thing I hate... For I know that nothing good dwells within me, that is, in my flesh. I can will what is right, but I cannot do it. For I do not do the good I want, but the evil I do not want is what I do. Now if I do what I do not want, it is no longer I that do it, but sin which dwells within me...Wretched man that I am! Who will deliver me from this body of death? Thanks be to God through Jesus Christ our Lord!...

Mk. 10:24, 26-27. ..Jesus said to [his disciples], "Children, how hard it is to enter the kingdom of God!" ..And they were exceedingly astonished, and said to him, 'Then who can be saved?" Jesus looked at them and said, "With men it is impossible, but not with God; for all things are possible with God."

Jn. 6:35, 37. Jesus said to them, "...All that the Father gives me will come to me; and him who comes to me I will not cast out."

Mk. 5:36. ..Jesus said..."Do not fear, only believe." Jn. 3:16. For God so loved the world that he gave his only Son, that whoever believes in him should not perish but have eternal life.
Jn. 12:42. Many even of the authorities believed in [Jesus], but for fear of the Pharisees they did not confess it...

Rev. 3:2 [Christ]: Awake, and strengthen what remains and is on the point of death, for I have not found your works perfect..

Is. 35:3-4. Strengthen the weak hands, and make firm the feeble knees. Say to those who are of a fearful heart, "Be strong, fear not! ..."

Lk. 8:50 [Christ]: ...Do not fear; only believe...'

Lk. 22:32 [Christ]: I have prayed for you that your faith may not fail...

Jn. 3:14-15 [Christ]: As Moses lifted up the serpent in the wilderness, so must the Son of man be lifted up, that whoever believes in him may have eternal life.

Jn. 3:16 [Christ]: For God so loved the world that he gave his only Son, that whoever believes in him should not perish but have eternal life. 
Werd ich dort oben

Sball I up-there

Mit Danken und Loben

With giving-of-thanks and extolling

Vater, Sohn und Heilgen Geist

Father, Son, and Holy Ghost

Preisen, der dreieinig heißt.

Praise, who triune is-called.

(Up there in heaven I shall praise Father, Son, and Holy

Ghost--who is called the triune God--with giving of

thanks and extolling.)
Rom. 5:1-2. Therefore, since we are justified by faith, we have peace with God through our Lord Jesus Christ. Through him we have obtained access to this grace in which we stand, and we rejoice in our hope of sharing the glory of God.

Jude 1:24-25. To him who is able to keep you from falling and to present you without blemish before the presence of his glory with rejoicing, to the only God, our Savior through Jesus Christ our Lord, be glory, majesty. dominion, and authority, before all time and now and forever. Amen.

Rev. 5:11-13. Then [in my vision] I looked, and I heard around the throne and the living creatures and the elders the voice of many angels, numbering myriads of myriads and thousands of thousands, saying with a loud voice, "Worthy is the Lamb who was slain. to receive power and wealth and wisdom and might and honor and glory and blessing!" And I heard every creature in heaven and on earth and under the earth and in the sea, and all therein, saying, "To him who sits upon the throne and to the Lamb be blessing and honor and glory and might forever and ever!"

Mt. 28:19. ...in the name of the Father and of the Son and of the Holy Spirit...

Jn. 3:3, 5. Jesus answered, 'Truly, truly, I say to you, unless one is born anew, he cannot see the kingdom of God...Truly, truly, I say to you, unless one is born of water and the Spirit, he cannot enter the kingdom of God."

Rev. 11:15. ...The kingdom of the world has become the kingdom of our Lord and of his Christ, and he shall reign forever and ever.

Rev. 4:8. And the four living creatures, each of them with six wings...day and night they never cease to sing, "Holy, holy, holy, is the Lord God Almighty, who was and is and is to come!"

1 Tim. 6:15-16. ...[He is] the blessed and only Sovereign, the King of kings and Lord of lords, who alone has immortality and dwells in unapproachable light... To him be honor and eternal dominion. Amen.

Rev. 17:14....He is Lord of lords and King of kings, and those with him are called and chosen and faithful.

Ps. 95:3. The Lord is a great God, and a great King above all gods.

Ps. 144:1-2. Blessed be the Lord...my stronghold and my deliverer...

Ex. 15:13. [O Lord,] thou hast led in thy steadfast love the people whom thou hast redeemed, thou hast guided them by thy strength to thy holy abode.

Jn. 3:5, 13, 16. ...Unless one is born of water and the Spirit, he cannot enter the kingdom of God... No one has ascended into heaven but he who descended from heaven, the Son of man... God so loved the world that 
Der Frommen Schutz und Retter, Of godly-men (the) refuge and Savior,

Ein Wesen, drei Personen.

One being (in) three persons. he gave his only Son... [Trinity = God, Son, and Spirit] Mt. 28:19. ...in the name of the Father and of the Son and of the Holy Spirit... ${ }^{16}$

\title{
Gelobet sei der Herr, BWV 129
}

Praised be the Lord, my God ${ }^{17}$

\author{
Librettist: Johann Olearius
}

Scripture readings for the day of the first performance, Trinity Sunday, June 16, $1726{ }^{18}$ : Rom. 11:33-36 (O the depth of the riches and wisdom and knowledge of God!)

Jn. 3:1-15 (Discussion between Jesus and Nicodemus: You must be born anew)

Following is a table of the libretto translations, scriptural allusions, and the first lines of the scriptural passages (unless the full passages seem particularly significant for the cantata):

\begin{tabular}{l|l} 
Translation & Scripture \\
\hline $\begin{array}{l}1 \text { - Chorus [S, A, T, B] - [Chorale Vs. 1] } \\
\text { Trumpets 1-III, Timpani, Transverse Flute, Oboes I/II, } \\
\text { Violins 1/II, Viola, Organ, and Basso Continuo }\end{array}$ & $\begin{array}{l}\text { 1 Kings 8:56. Blessed be the Lord.. } \\
\text { Ps. 113:2. Blessed be the name of the Lord from this } \\
\text { time forth and for evermore! } \\
\text { Rom. 11:33, 36. O the depths of the riches and wisdom } \\
\text { and knowledge of God! How unsearchable are his } \\
\text { judgments and how inscrutable his ways! ..For from } \\
\text { him and through him and to him are all things. To him } \\
\text { be glory forever. Amen. } \\
\text { Ps. 27:1. The Lord is my light and my salvation ...The } \\
\text { Lord is the stronghold of my life... } \\
\text { Ps. 100:3. Know that the Lord is God! It is he that } \\
\text { made us, and we are his... } \\
\text { Ps. 139:13-16. [0 Lord,] thou didst form my inward } \\
\text { parts, thou didst knit me together in my mother's womb. } \\
\text { I praise thee, for thou art fearful and wonderful. } \\
\text { Wonderful are thy works! Thou knowest me right well; } \\
\text { melobet sei der Herr, } \\
\text { my frame was not hidden from thee, when I was being } \\
\text { made in secret, intricately wrought in the depths of the } \\
\text { earth. Thy eyes beheld my unformed substance; in thy }\end{array}$ \\
$\begin{array}{l}\text { Mein Gott. mein Licht, mein Leben, } \\
\text { Mein Schöpfer, der mir hat }\end{array}$ \\
$\begin{array}{l}\text { My Creator, who me hath } \\
\text { (My creator, who hath given me) }\end{array}$ \\
$\begin{array}{l}\text { Mein Leib und Seel gegeben, } \\
\text { My body and soul given, } \\
\text { (My body and soul,) }\end{array}$
\end{tabular}

\footnotetext{
${ }^{16}$ Unger, Handbook to Bach's Sacred Cantata Texts: An Interlinear Translation with Reference Guide to Biblical Quotations and Allusions, 609-612. All quoted or paraphrased elements of this cantata's appendix are from Unger unless otherwise marked.

${ }^{17}$ David Humphreys, "Gelobet sei der Herr, mein Gott," In Oxford Composer Companions: J. S. Bach, ed. Malcolm Boyd (Oxford: Oxford University Press, 1999), 188

${ }^{18}$ Alfred Dürr, The Cantatas of J. S. Bach: With Their Librettos in German-English Parallel Text, trans. Richard D. P. Jones (Oxford: Oxford University Press, 2005), 379.

${ }^{19}$ The cantata is a five-movement composition based on the chorale "Gelobet sei der Herr, mein Gott" by Johann Olearius. Each stanza of the chorale is set by each movement of the cantata.
} 
Mein Vater, der mich schützt

My Father, who me protects

(My Father, who protects me)

Von Mutterleibe an,

From (my) mother's-womb on,

(Since my mother's womb,)

Der alle Augenblick

Who (each) moment (of my life)

Viel Guts an mir gatan.

Much good to me hath-done.

(Hath done much good to me.)

2 - Aria [Bass] - [Chorale Vs. 2]

Organ and Basso Continuo

Praise to God the Son: my Salvation, my life

Gelobet sei der Herr,

Blessed be the Lord.

Mein Gott, mein Heil, mein Leben,

My God, my salvation, my life,

Des Vaters liebster Sohn,

The Father's dearest Son,

Der sich für mich gegeben.

Who himself for me did-give,

(Who gave himself for me,)

Der mich erlöset hat

Who me redeemed hath

(Who redeemed me)

Mit seinem teuren Blut,

With his precious blood,

Der mir im Glauben schenkt

Who to-me through faith doth-give

Sich selbst. das höchste Gut.

Him-self, the highest good.

(Who gives himself, the highest good, to me by faith.)

3 - Aria [Soprano] - [Chorale Vs. 3]

Transverse flute, Violin solo, Organ, and Basso

Continuo book were written, every one of them, the days that were formed for me, when as yet there was none of them.

Ps.103:13. As a father pities his children, so the Lord pities those who fear him.

Ps. 22:9-10. [O Lord,] thou art he who took me from the womb; thou didst keep me safe upon my mother's breasts. Upon thee was I cast from my birth, and since my mother bore me thou hast been my God.

Ps. 71:5-6. Thou, O Lord, art my hope, my trust, O Lord, from my youth. Upon thee I have leaned from my birth; thou art he who took me from my mother's womb. My praise is continually of thee.

Ps. 116:7. ...The Lord has dealt bountifully with you... Lam. 3:22-23. The steadfast love of the Lord never ceases, his mercies never come to an end; they are new every morning; great is thy faithfulness.

Lk. 1:68-69. Blessed be the Lord God...for he has visited and redeemed his people, and has raised up a horn of salvation for us ...

Jn. 3:16. For God so loved the world that he gave his only Son, that whoever believes in him should not perish but have eternal life.

Gal. 1:3-4. ...Our Lord Jesus Christ...gave himself for our sins to deliver us from the present evil age...

Tit. 2:13-14. ...Our great God and Savior Jesus Christ...gave himself for us to redeem us from all iniquity...

1 Jn. 4:10. In this is love, not that we loved God but that he loved us and sent his Son to be the expiation for our sins.

1 Tim. 2:5-6. For there is one God, and there is one mediator between God and men, the man Christ Jesus, who gave himself as a ransom for all.

1 Pet. 1:18-19. You...were ransomed ...not with perishable things such as silver or gold, but with the precious blood of Christ, like that of a lamb without blemish or spot.

Eph. 3:17. ... that Christ may dwell in your hearts through faith ...

1 Jn. 1:3. ... Our fellowship is with the Father and with his Son Jesus Christ.

Ps. 16:5. The Lord is my chosen portion and my cup...
Ps. 73:26. [O Lord,] my flesh and my heart may fail, but God is the strength of my heart and my portion forever.

Jn. 14:16-17 [Christ]: I will pray the Father, and he will 
Praise to God the Holy Ghost: my comfort and strength

Gelobet sei der Herr,

Blessed be the Lord,

Mein Gott, mein Trost, mein Leben,

My God, my comfort, my life,

Des Vaters werter Geist,

The Father's precious Spirit,

Den mir der Sohn gegeben,

Whom me the Son did-give,

(Who was given to me by the Son,)

Der mir mein Hertz erquickt.

Who - my heart doth-revive,

(Who revives my heart,)

Der mir gibt neue Kraft,

Who to-me doth-give new strength,

(Who gives me new strength,)

Der mir in aller Not

Who me in all distress

(Who provides me in all distress)

Rat, Trost und Hülfe schafft.

Counsel, comfort, and help provideth.

(With counsel, comfort, and help.) give you another Counselor, to be with you forever, even the Spirit of truth...He dwells with you, and will be in you.

1 Cor. 12:13. ... [We] all were made to drink of one Spirit.

Rom. 5:5. ...God's love has been poured into our hearts through the Holy Spirit which has been given to us.

Gal. 4:6. Because you are sons. God has sent the Spirit of his Son into our hearts, crying, "Abba! Father!"

Jn. 16:13-14 [Christ]: When the Spirit of truth comes. he will guide you into all the truth; for he will not speak on his own authority, but whatever he hears he will speak...He will take what is mine and declare it to you.

Rom. 11:33-34. O the depths of the riches and wisdom and knowledge of God! How unsearchable are his judgments and how inscrutable his ways! "For who has known the mind of the Lord, or who has been his counselor?"

Jn. 14:26 [Christ]: But the Counselor, the Holy Spirit, whom the Father will send in my name, he will teach you all things...

Acts 1:8 [Christ]: You shall receive power when the Holy Spirit has come upon you...

Is. 40:29-31. [The Lord] gives power to the faint, and to him who has no might he increases strength. Even youths shall faint and be weary, and young men shall fall exhausted; but they who wait for the Lord shall renew their strength, they shall mount up with wings like eagles, they shall run and not be weary, they shall walk and not faint.

Ps. 34:17, 19. When the righteous cry for help, the Lord hears, and delivers them out of all their troubles ...Many are the afflictions of the righteous; but the Lord delivers him out of them all.

Ps. 89:52. Blessed be the Lord forever! Amen and Amen.

Ps. 106:48. Blessed be the Lord ...from everlasting to everlasting! And let all the people say, "Amen!" Praise the Lord!

Rom. 11:36. From him and through him and to him are all things. To him be glory forever. Amen.

Ps. 150:6. Let everything that breathes praise the Lord!.

Rev. 4:10. The twenty-four elders fall down before him who is seated on the throne and worship him who lives forever and ever...

Ps. 148:1-4. Praise the Lord! Praise the Lord from the heavens, praise him in the heights! Praise him, all his angels, praise him, all his host! Praise him, sun and moon, praise him, all you shining stars! Praise him, you highest heavens, and you waters above the heavens!

Is. 6:1-3. ...I saw the Lord sitting upon a throne, high 
Gelobet sei der Herr, Blessed be the Lord,

Des Name heilig heißt, Whose name Holy is-called, (Whose name is called Holy,)

Gott Vater, Gott der Sohn

God (the) Father, God the Son,

Und Gott der Heilge Geist. And God the Holy Ghost.

5 - Chorale [S, A, T, B] - [Chorale Vs. 5]

Trumpets I-III, Timpani, Transverse Flute, Oboes I/II, Violins I/II, Viola, Organ, and Basso Continuo

Praise to the Trinity; singing "Holy" with angels

Mit Freuden lassen klingen

With joy let resound

(The one to whom we now let that Sanctus joyfully resound)

Und mit der Engel Schar

And with the angel host

Das Heilig, Heilig singen, That "Holy, Holy" sing,

Den herzlich lobt und preist

Whom heartily doth-laud and praise

Die ganze Christenheit:

The entire Christendom:

(Whom the entire Christendom doth heartily laud and praise:)

Gelobet sei mein Gott

Praised be my God

In alle Ewigkeit!

For all eternity! and lifted up; and his train filled the temple. Above him stood the seraphim; each had six wings: with two he covered his face, and with two he covered his feet, and with two he flew. And one called to another and said: "Holy, holy, holy is the Lord of hosts; the whole earth is full of his glory."

1 Sam. 2:2. There is none holy like the Lord...

Is. 57:15. [He is] the high and lofty One who inhabits eternity, whose name is Holy...

Mt. 28:19. ...the name of the Father and of the Son and of the Holy Spirit.

Rom. 11:36. From him and through him and to him are all things. To him be glory forever. Amen.

Rev. 4:8-11. And the four living creatures, each of them with six wings, are full of eyes all round and within, and day and night they never cease to sing, "Holy, holy, holy, is the Lord god almighty, who was and is and is to come!” and whenever the living creatures give glory and honor and thanks to him who is seated on the throne, who lives forever and ever, the twenty-four elders fall down before him who is seated on the throne and worship him who lives forever and ever; they cast their crowns before the throne, singing, "Worthy are thou, our Lord and God, to receive glory and honor and power, for thou didst create all things, and by thy will they existed and were created."

Rev. 5:11-14. Then I looked, and I heard around the throne and the living creatures and the elders the voice of many angels, numbering myriads of myriads and thousands of thousands, saying with a loud voice, "Worthy is the Lamb who was slain, to receive power and wealth and wisdom and might and honor and glory and blessing!” and I heard every creature in heaven and on earth and under the earth and in the sea, and all therein, saying, "To him who sits upon the throne and to the Lamb be blessing and honor and glory and might forever and ever!” and the four living creatures said, "Amen!" and the elders fell down and worshiped.

Ps. 106:48. Blessed be the Lord, the God of Israel, from everlasting to everlasting! And let all the people say, “Amen!” Praise the Lord! ${ }^{20}$

${ }^{20}$ Unger, Handbook to Bach's Sacred Cantata Texts: An Interlinear Translation with Reference Guide to Biblical Quotations and Allusions, 448-450. All quoted or paraphrased elements of this cantata's appendix are from Unger unless otherwise marked. 


\section{Bibliography}

Adams, Howard C. "The Contemporizing of Scripture in the Cantatas of Johann Sebastian Bach.” In Johann Sebastian: A Tercentenary Celebration, edited by Seymour L. Benstock, 5-10. Westport, CT: Greenwood Press, 1992.

Bach, Johann Sebastian. BWV 194a, Edited by Alfred Dürr. Neue Ausgabe sämtlicher Werke, ser. 1, vol. 35, Festmusiken für die Fürstenhäuser von Weimar, Weißenfels und Köthen. Kassel, Germany: Bärenreiter, 1987.

-. Es ist ein troztig und verzagt Ding, BWV 176. Edited by Alfred Dürr and Robert Freeman. Neue Ausgabe sämtlicher Werke, ser. 1, vol. 15, Kantaten. Kassel, Germany: Bärenreiter, 1967.

—. Gelobet sei der Herr, mein Gott, BWV 129. Edited by Alfred Dürr and Robert Freeman. Neue Ausgabe sämtlicher Werke, ser. 1, vol. 15, Kantaten. Kassel, Germany: Bärenreiter, 1967.

—. Höchsterwünschtes Freudenfest, BWV 194. Edited by Frieder Rempp. Neue Ausgabe sämtlicher Werke, ser. 1, vol. 31, Kantaten. Kassel, Germany: Bärenreiter, 1987.

—. O heilges Geist- und Wasserbad, BWV 165. Edited by Alfred Dürr and Robert Freeman. Neue Ausgabe sämtlicher Werke, ser. 1, vol. 15, Kantaten. Kassel, Germany: Bärenreiter, 1967.

Baron, Carol K., ed. Bach's Changing World: Voices in the Community. Rochester, NY: University of Rochester Press, 2006.

—. “Transitions, Transformations, Reverals: Rethinking Bach’s World.” In Bach's Changing World: Voices in the Community, edited by Carol K. Baron, 2-34. Rochester, NY: University of Rochester Press, 2006.

—. “Tumultuous Philosophers, Pious Rebels, Revolutionary Teachers, Pedantic Clerics, Bengeful Bureaucrats, Threatened Tyrants, Worldly Mystics: The Religious World Bach Inherited." In Bach's Changing World: Voices in the Community, edited by Carol K. Baron, 35-85. Rochester, NY: University of Rochester Press, 2006.

Bartels, Harry. "Paul Gerhardt and J. S. Bach.” Evangelical Lutheran Synod. http://www.evangelicallutheransynod.org/publications/sentinel/2007/03/05Gerhard.html (accessed September 17, 2010).

Beller-McKenna, Catherine Pearson. “The Voice of Luther’s Church: Instrumental Cantus Firmus Chorales in Selected Cantatas by Johann Sebastian Bach.” DMA diss., University of South Carolina, 1998. 
Besseler, Heinrich. Neue Ausgabe Sämtlicher Werke (New Edition of All the Works). ser. 5, vol. 1. Kassel, Germany: Bärenreiter, 1967.

Boyd, Malcolm, ed. Oxford Composer Companions: J. S. Bach. Oxford: Oxford University Press, 1999.

Browne, Francis. "Cantata BWV 194 - English Translation." Bach Cantatas Website. 2002. http://www.bach-cantatas.com/Texts/BWV194-Eng3.htm (accessed November 27, 2009).

Burdick, Adam David. "The Influence of French Baroque Dance on the Cantatas of Johann Sebastian Bach.” DMA diss., University of Washington, 2007.

Burgess, Geoffrey and Bruce D. Haynes. The Oboe. New Haven, CT: Yale University Press, 2004.

Butt, John. The Cambridge Companion to Bach. New York: Cambridge University Press, 1997.

Chafe, Eric. Analyzing Bach Cantatas. New York: Oxford University Press, 2000.

-. Tonal Allegory in the Vocal Music of J. S. Bach. Berkeley: University of California Press, 1991.

Christian, Johann. "O heilges Geist- und Wasserbad." In Oxford Composer Companions: J. S. Bach, edited by Malcom Boyd, 331-332. Oxford: Oxford University Press, 1999.

Cowdery, William Warren. "The Early Vocal Works of Johann Sebastian Bach: Studies in Style, Scoring, and Chronology.” PhD diss., Cornell University, 1989.

Dahlqvist, Reine. “Taille, Oboe da Caccia and Corno Inglese.” The Galpin Society Journal 26 (May 1973): 58-71.

David, Hans T., et al. The New Bach Reader: A Life of Johann Sebastian Bach in Letters and Documents. New York: W. W. Norton, 1998.

Daw, Stephen. The Music of Johann Sebastian Bach, the Choral Works. Rutherford, NJ: Fairleigh Dickinson University Press, 1981.

Dirst, Matthew. "Bach’s French Overtures and the Politics of Overdotting." Early Music 25, no. 1 (February 1997): 35-44.

Dürr, Alfred. The Cantatas of J. S. Bach: With Their Librettos in German-English Parallel Text. Translated by Richard D. P. Jones. Oxford: Oxford University Press, 2005.

Ferer, Mary. "Pre-Leipzig Cantatas." Class lecture, Music 791: The Music of J. S. Bach and Musical Life in Eighteenth-Century Germany, West Virginia University, Morgantown, WV, 2009. 
Fitsioris, George, and Darrell Conklin. "Parallel Successions of Perfect Fifths in Bach Chorales." Proceedings of the Fourth Conference on Interdisciplinary Musicology (CIM08), Thessaloniki, Greece, 3-6 July 2008. http://web.auth.gr/cim08/ (accessed 6 June 2010).

Gardiner, John Eliot. "Bach Cantata Series: Cantatas for Trinity Sunday." Soli Deo Gloria. http://www.solideogloria.co.uk/recordings/bach_cantatas.cfm (accessed August 19, 2010).

Gardiner, John Eliot, dir., Monteverdi Choir and English Baroque Soloists. Bach Cantatas Vol. 27: Blythburgh/Kirkwell. Soli Deo Gloria. CD. 2000.

Google. "Störmthal, Grosspösna, Deutschland to Leipzig, Deutschland.” Google Maps. http://maps.google.com/ (accessed August 25, 2010).

Harbison, John "Emmanuel Music - Bach Cantata Notes - BWV 176." Emmanuel Music. http://www.emmanuelmusic.org/notes_translations/notes_cantata/n_bwv176.htm (accessed July 1, 2010).

Hirsch, Arthur. "Number Symbolism in Bach’s First Cantata Cycle: 1723-1724, Part II.” Bach: The Quarterly Journal of the Riemenscheider Bach Institute 6, no. 4 (October 1975): 1419.

Humphreys, David. "Gelobet sei der Herr, mein Gott." In Oxford Composer Companions: J. S. Bach, edited by Malcom Boyd, 188. Oxford: Oxford University Press, 1999.

—. "Höchsterwünschtes Freudenfest." In Oxford Composer Companions: J. S. Bach, edited by Malcom Boyd, 221-222. Oxford: Oxford University Press, 1999.

Irwin, Joyce. "Bach in the Midst of Religious Transition.” In Bach's Changing World: Voices in the Community, edited by Carol K. Baron, 108-126. Rochester, NY: University of Rochester Press, 2006.

Jeske, Richard L. "Bach as Biblical Interpreter.” In The Universal Bach: Lectures Celebrating the Tercentenary of Bach's Birthday, 80-92. Philadelphia: American Philosophical Society, 1986.

Joyce, George. "The Blessed Trinity." The Catholic Encyclopedia, Vol. 15. New York: Robert Appleton Company, 1912. http://www.newadvent.org/cathen/15047a.htm (accessed September 14, 2010).

Julian, John. "Olearius, Johannes” from Dictionary of Hymnology (1907). Hymnary.org, Calvin College, Grand Rapids, MI. http://www.hymnary.org/person/Olearius_J (accessed September 6, 2010). 
Kevorkian, Tanya. "The Reception of the Cantata during Leipzig Church Services, 1700-1750..” In Bach’s Changing World: Voices in the Community, edited by Carol K. Baron, 174189. Rochester, NY: University of Rochester Press, 2006.

Koopman, Ton, dir., Amsterdam Baroque Orchestra and Choir. J. S. Bach: Complete Cantatas Vol. 3. Erato / Antoine Marchand. CD. 1995.

—. J. S. Bach: Complete Cantatas Vol. 9. Erato / Antoine Marchand. CD. 1998.

—. J. S. Bach: Complete Cantatas Vol. 15. Erato / Antoine Marchand. CD. 2002.

—. J. S. Bach: Complete Cantatas Vol. 19. Erato / Antoine Marchand. CD. 2003.

Koopman, Ton. “Recording Bach’s Early Cantatas.” Early Music 24, no. 4 (Nov, 1996): 605621.

Kuhnau, Johann and Ruben Weltsh, trans. “A Treatise on Liturgical Text Settings (1710).” In Bach's Changing World: Voices in the Community, edited by Carol K. Baron, 219-226. Rochester, NY: University of Rochester Press, 2006.

Küster, Konrad. “Cantata.” In Oxford Composer Companions: J. S. Bach, ed. Malcolm Boyd, 82-89. Oxford: Oxford University Press, 1999.

—. "Franck, Solomo.” In Oxford Composer Companions: J. S. Bach, edited by Malcolm Boyd, 176-177. Oxford: Oxford University Press, 1999.

Leaver, Robin A. "Bach's Understanding and Use of the Epistles and Gospels of the Church Year.” Bach: The Quarterly Journal of the Riemenscheider Bach Institute 6, no. 4 (October 1975): 4-13.

—. "Eschatology, Theology and Music: Death and Beyond in Bach’s Vocal Music.” In Irish Musical Studies, 8: Bach Studies from Dublin, edited by Anne Leahy and Yo Tomita, 129--147. Dublin: Four Courts Press, 2004.

—. "Jahrgang." In Oxford Composer Companions: J. S. Bach, ed. Malcolm Boyd, 245. Oxford: Oxford University Press, 1999.

-. J. S. Bach and Scripture: Glosses from the Calov Bible Commentary. St. Louis: Concordia Pub. House, 1985.

-. "Johann Sebastian Bach and the Lutheran Understanding of Music.” Lutheran Quarterly 16, no. 1 (2002): 21-47.—. "Johann Sebastian Bach: Theological Musician and Musical Theologian.” BACH: Journal of the Riemenschneider Bach Institute 31, no. 1 (January 2000): 17-33. 
—. "Johann Sebastian Bach: Theological Musician and Musical Theologian." BACH: Journal of the Riemenschneider Bach Institute 31, no. 1 (January 2000): 17-33.

-. Music as Preaching: Bach, Passions, and Music in Worship. Latimer Series 13. Oxford: Latimer House, 1982.- . "Performing Bach: One or Many?” The Choral Scholar, the Online Journal of the National Collegiate Choral Organization 1, no. 1 (Spring 2009): 615

—. "The Liturgical Place and Homiletic Purpose of Bach’s Cantatas.” Worship 59 (1985): 194202.

—. "The Liturgical Place and Homiletic Purpose of Bach’s Cantatas.” Worship 59 (1985): 194202.Leisinger, Ulrich. “Affections, Rhetoric, and Musical Expression.” In The World of the Bach Cantatas: Johann Sebastian Bach's Early Sacred Cantatas, edited by Christoph Wolff, 184-197. New York: Norton, 1997.

Leisinger, Ulrich. “Affections, Rhetoric, and Musical Expression.” In The World of the Bach Cantatas: Johann Sebastian Bach's Early Sacred Cantatas, edited by Christoph Wolff, 184-197. New York: Norton, 1997.

Liberty Fund, Inc. "Online Library of Liberty - Cantata XXIX: Gelobet sei der Herr, Trinity Sunday (1732)." The Online Library of Liberty. http://oll.libertyfund.org/?option=com_staticxt\&staticfile=show.php\%3Ftitle=2056\&chap ter=197301\&layout=html\&Itemid=27 (accessed September 9, 2010).

Loft Recordings. "Störmthal, Germany: Hildebrandt organ (1723)." The Gothic Catalog. http://www.gothic-catalog.com/St_rmthal_Germany_Hildebrandt_organ_1723_s/884.htm (accessed December 20, 2009).

Marissen, Michael. "Historically Informed Rendering of the Librettos from Bach's Church Cantatas.” In Music and Theology: Essays in Honor of Robin A. Leaver, 103-120. Lanham, MD: Scarecrow Press, 2007.

Melamed, Daniel R. "Cantata Choruses and Chorales.” In The World of the Bach Cantatas: Johann Sebastian Bach's Early Sacred Cantatas, edited by Christoph Wolff, 154-169. New York: Norton, 1997.

Mershman, Francis. "Trinity Sunday." The Catholic Encyclopedia. Vol. 15. New York: Robert Appleton Company, 1912. http://www.newadvent.org/cathen/15058a.htm (accessed October 5, 2009).

Meyer, Ulrich. Biblical Quotation and Allusion in the Cantata Libretti of Johann Sebastian Bach, edited by Robin A. Leaver. Lanham, MD: Scarecrow Press, 1997.

NetHymnal. "Paul Gerhardt.” http://nethymnal.org/bio/g/e/gerhardt_p.htm (accessed September 17, 2010). 
Neumann, Werner. Handbook of Joh. Seb. Bach's Cantatas. New York: Associated Music, 1947.

Oremus Bible Browser. "Oremus Bible Browser: John 3:1-15 (The New Revised Standard Version)." June 19, 2010. http://bible.oremus.org/ (accessed September 14, 2010).

Oremus Bible Browser. "Oremus Bible Browser: Revelation 21:2-8 (The New Revised Standard Version)." June 19, 2010. http://bible.oremus.org/ (accessed September 17, 2010).

Oremus Bible Browser. "Oremus Bible Browser: Romans 11:33-36 (The New Revised Standard Version)." June 19, 2010. http://bible.oremus.org/ (accessed September 14, 2010).

Oron, Aryeh. Bach Cantatas Website. http://www.bach-cantatas.com (accessed September 5, 2009).

—. "Ludwig Helmbold (Hymn-Writer).” Bach Cantatas Website. 2006. http://www.bachcantatas.com/Lib/Helmbold.htm (accessed September 18, 2010).

—. "Paul Gerhardt (Hymn-Writer).” Bach Cantatas Website. 2009. http://www.bachcantatas.com/Lib/Gerhardt.htm (accessed September 17, 2010).

Oron, Aryeh and Thomas Braatz. "Johann Heermann (Hymn-Writer).” Bach Cantatas Website. 2008. http://www.bach-cantatas.com/Lib/Heermann.htm (accessed September 17, 2010).

Oron, Aryeh, and Thomas Shepherd. "Cantata BWV 165 - Recordings - Part 1.” Bach Cantatas Website. 2008. http://www.bach-cantatas.com/BWV165.htm (accessed September 5, 2009).

—. “Cantata BWV 194 - Recordings - Part 1.” Bach Cantatas Website. 2008. http://www.bachcantatas.com/BWV165.htm (accessed September 5, 2009).

Oron, Aryeh, et al. “Cantata BWV 129 - Recordings - Part 1.” Bach Cantatas Website. 2008. http://www.bach-cantatas.com/BWV129.htm (accessed September 5, 2009).

—. "Cantata BWV 176 - Recordings - Part 1.” Bach Cantatas Website. 2008. http://www.bachcantatas.com/BWV176.htm (accessed September 5, 2009).

Patrizia, Metzler. "Aria Forms and Chorus Textures in Bach's Early Cantatas: The influences of Neumeister, Telemann, and Rosenmueller.” DMA diss., University of Illinois at UrbanaChampaign, 2007.

Parrott, Andrew. “Bach’s Chorus: Who Cares?” Early Music 25, no. 2 (May 1997): 297-300.

—. The Essential Bach Choir. Woodbridge, Suffolk, UK: Boydell Press, 2000.

Peters, Mark A. A Woman's Voice in Baroque Music: Mariane Von Ziegler and J. S. Bach. Burlington, VT: Ashgate, 2008. 
Petzoldt, Martin. “Gottes wohnung beim Menschen: Bachs Kirchweihkantate Höchsterwünschtes Freudenfest, BWV 194.” In Die Quellen Johann Sebastian Bachs, Bachs Musik im Gottesdienst, edited by Helmuth Rilling and Renate Steiger, 135-151. Germany: Manutius Heidelberg, 1998.

—. "Liturgical and Theological Aspects." In The World of the Bach Cantatas: Johann Sebastian Bach’s Early Sacred Cantatas, edited by Christoph Wolff, 108-123. New York: Norton, 1997.

Prinz, Ulrich. “Bassoon.” In Oxford Composer Companions: J. S. Bach, ed. Malcolm Boyd, 5960. Oxford: Oxford University Press, 1999.

Rifkin, Joshua. Bach’s Choral Ideal. Dortmund: Klangfarben-Musikverlag, 2002.

—. "Bassoons, Violins and Voices: A Response to Ton Koopman.” Early Music 25, no. 2 (May 1997): 303-307.

Rilling, Helmut, dir., Frankfurter Kantorei / Bach-Collegium Stuttgart. Die Bach Kantate Vol. 38; Edition Bachakademie Vol. 50. Hänssler. CD. 1976.

—, dir., Gächinger Kantorei Stuttgart / Bach-Collegium Stuttgart. Die Bach Kantate Vol. 65; Edition Bachakademie Vol. 58. Hänssler. CD. 1977.

—. Die Bach Kantate Vol. 39; Edition Bachakademie Vol. 53. Hänssler. CD. 1980.

—. Die Bach Kantate Vol. 10; Edition Bachakademie Vol. 40. Hänssler. CD. 1982.

-. Helmuth Rilling: The Oregon Bach Festival Master Class Lectures, Volume II, 1982, 1983 -part I. Edited by Marla Lowen. Dayton, OH: Roger Dean, 2000.

Robertson, Alec. The Church Cantatas of J. S. Bach. New York: Praeger, 1972.

Scheibel, Gottfried Ephraim and Joyce Irwin, trans. "Random Thoughts About Church Music in Our Day (1721).” In Bach’s Changing World: Voices in the Community, edited by Carol K. Baron, 227-249. Rochester, NY: University of Rochester Press, 2006.

Schulenberg, David. “Es ist ein trotzig un verzagt Ding.” In Oxford Composer Companions: J. S. Bach, edited by Malcom Boyd, 163-164. Oxford: Oxford University Press, 1999.

Schulze Hans-Joachim. "Bach the Composer." In The World of the Bach Cantatas: Johann Sebastian Bach's Early Sacred Cantatas, edited by Christoph Wolff, 93-97. New York: Norton, 1997.

—. "Poetry and Poets.” In The World of the Bach Cantatas: Johann Sebastian Bach's Early Sacred Cantatas, edited by Christoph Wolff, 100-107. New York: Norton, 1997. 
—, ed. Die Thomasschule Leipzig zur Zeit Johann Sebastian Bachs: Ornungen und Gesetze 1634, 1723, 1733. Leipzig, 1987.

—. "The French Influence in Bach’s Instrumental Music.” Early Music 13, no. 2 (May 1985): 180-184.

Smallman, Basil. "Bach, Johann Sebastian.” In The Oxford Companion to Music. Edited by Alison Latham. Oxford Music Online. http://www.oxfordmusiconline.com/subscriber/article/opr/t114/e522 (accessed September 6, 2009).

Smith, Craig. "Emmanuel Music - Bach Cantata Notes - BWV 129.” Emmanuel Music. http://www.emmanuelmusic.org/notes_translations/notes_cantata/n_bwv129.htm\#pab1_7 (accessed September 6, 2009).

—. "Emmanuel Music - Bach Cantata Notes - BWV 165.” Emmanuel Music. http://www.emmanuelmusic.org/notes_translations/notes_cantata/n_bwv165.htm\#pab1_7 (accessed September 6, 2009).

Smithers, Don L. "The Original Circumstances in the Performance of Bach’s Leipzig Church Cantatas, 'wegen seiner Sonn- und Festtägigen Amtz-Verrichtungen.'” In Johann Sebastian: A Tercentenary Celebration. Edited by Seymour L. Benstock, 111-126. Westport, CT: Greenwood Press, 1992.

Steiger, Renate. "Dialogue Structures in J. S. Bach's Cantatas: The Basic Form of Worship as a Model for Artistic Shaping.” Translated by Greta Konradt. BACH: Journal of the Reimenschneider Bach Institute 33, no. 2 (2002): 35-70.

Stiller, Günther, and Robin A. Leaver. Johann Sebastian Bach and Liturgical Life in Leipzig. Translated by Herbert J. A. Bouman, Daniel F. Poellot, and Hilton C. Oswald. St. Louis, MO: Concordia Pub. House, 1984.

Strunk Jr., William and E. B. White. The Elements of Style. $4^{\text {th }}$ ed. New York: Longman Publishers, 2000.

Suzuki, Masaaki, dir., Bach Collegium Japan. J S. Bach: Cantatas Vol. 4. BIS 801. CD. 1996.

—. J S. Bach: Cantatas Vol. 16 - Cantatas from Leipzig 1723. BIS 1131. CD. 2000.

—. J S. Bach: Cantatas Vol. 35 - Cantatas from Leipzig 1725. BIS 1131. CD. 2006.

Swack, Jeanne. “A Comparison of Bach's and Telemann's Use of the Overture as Theological Signifier.” Bach Perspectives 6 (2007): 99-135.

Terry, Charles Sanford. Cantata Texts, Sacred and Secular [by] Joh. Seb. Bach with a Reconstruction of the Leipzig Liturgy of His Period. London: Holland Press, 1964. 
Turabian, Kate L. A Manual for Writers of Research Papers, Theses, and Dissertations: Chicago Style for Students and Researchers. $7^{\text {th }}$ ed. Chicago: The University of Chicago Press, 2007.

Unger, Melvin P. "Bach's First Two Leipzig Cantatas: The Question of Meaning Revisited.” BACH: Journal of the Riemenschneider Bach Institute 28, no. 1-2 (Spring-Winter, 1997): $87-125$.

-.Handbook to Bach's Sacred Cantata Texts: An Interlinear Translation with Reference Guide to Biblical Quotations and Allusions. Lanham, MD: Scarecrow Press, Inc., 1996.

Westrup, J. A. Bach Cantatas. Seattle: University of Washington Press, 1969.

Winkworth, Catherine. "Christian Singers of Germany: Paul Gerhardt.” Calvin College Computer Science. http://www.ccel.org/ccel/winkworth/singers.gerhardt.html (accessed September 17, 2010).

Winkworth, Catherine, trans. "Online Library of Liberty - O Gott, du frommer Gott.” The Online Library of Liberty. http://oll.libertyfund.org/?option=com_staticxt\&staticfile=show.php \%3Ftitle=2057\&chapter=197699\&layout=html\&Itemid=27 (accessed October 1, 2010).

Whittaker, W. Gillies. The Cantatas of Johann Sebastian Bach: Sacred and Secular. Vols. 1 and 2. London: Oxford University Press, 1959.

Wolff, Christoph. Bach: Essays on His Life and Music. Cambridge, MA: Harvard University Press, 1991.

—. "Bachs Leipziger Kirchenkantaten: Repertoire and Kontext” ("Bach’s Leipzig Church Cantatas: Repertoire and Context”). In Johann Sebastian Bachs Leipziger Kirchenkantaten (Johann Sebastian Bach's Leipzig Church Cantatas), 13-36. Vol. 3 of Die Welt der Bach Kantaten, (The World of Bach Cantatas), edited by Christoph Wolff. Stuttgart: J. B. Metzler, 1997.

—. "Bach's Pre-Leipzig cantatas: Repertory and Context." In The World of the Bach Cantatas: Johann Sebastian Bach's Early Sacred Cantatas, edited by Christoph Wolff, 3-18. New York: Norton, 1997.

- "Choir and Instruments." In The World of the Bach Cantatas: Johann Sebastian Bach's Early Sacred Cantatas, edited by Christoph Wolff, 142-153. New York: Norton, 1997.

—. "Harvard@Home: Bach Manuscripts, with Professor Christoph Wolff.” Harvard University. http://athome.harvard.edu/dh/wolff.html (accessed September 6, 2009).

—.Johann Sebastian Bach: The Learned Musician. New York: W. W. Norton \& Company, Inc., 2000. 
Wolff, Christoph, et al. "Bach.” Grove Music Online. Oxford Music Online. http://www.oxfordmusiconline.com/subscriber/article/grove/music/40023pg10 (March 1, 2009).

Wollny, Peter. "Cantata Arias and Recitatives.” In The World of the Bach Cantatas: Johann Sebastian Bach’s Early Sacred Cantatas, edited by Christoph Wolff, 170-183. New York: Norton, 1997.

-. "Genres and Styles of Sacred Music Around 1700." In The World of the Bach Cantatas: Johann Sebastian Bach's Early Sacred Cantatas, edited by Christoph Wolff, 19-34. New York: Norton, 1997.

—. “New Bach Discoveries.” Bach-Jahrbuch 83 (1997): 7-50.

—. "Solokantaten und Solosätze" ("Solo Cantatas and Solo Forms"). In Johann Sebastian Bachs weltliche Kantaten (Johann Sebastian Bach’s Secular Cantatas), 189-200. Vol. 2 of Die Welt der Bach Kantaten, (The World of Bach Cantatas), edited by Christoph Wolff. Stuttgart: J. B. Metzler, 1997. 